PHILLIP JACOB

Transmedia Storytelling Systems in Publishing

With Focus on Fantasy Franchises 

PHILLIP JACOB

\section{Transmedia Storytelling Systems in Publishing}

With Focus on Fantasy Franchises 


\begin{abstract}
About the author
Phillip Jacob, Master of Engineering, born in 1994, graduated the HTWK in Leipzig and finds himself still at the beginning of his academic career. Until March 2020 he studied the master course "Media-Management" and the bachelor "Book and Media production" in Leipzig. In Parallel to his studies he worked as a project manager, graphic designer and an editor for a variety of national and international publishing service providers and media agencies.
\end{abstract}

Bibliographic information of the Deutsche Nationalbibliothek

The German National Library (Deutsche Nationalbibliothek) lists this work in the

Deutsche Nationalbibliografie; detailed bibliographic data is available in the internet via http://dnb.d-nb.de.

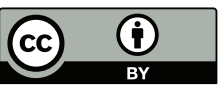

This work has been published under a Creative Commons license as

Open Access which requires only the attribution of the authors when

being reused.

License type: CC-BY 4.0 - more information:

口4p

http://creativecommons.org/licenses/by/4.0/

The online version of this publication is available at:

http://doi.org/10.33968/9783966270281-00

(C) 2021 Phillip Jacob

\title{
Publisher
}

Open-Access-Hochschulverlag

Hochschule für Technik, Wirtschaft und Kultur Leipzig (HTWK Leipzig)

Karl-Liebknecht-Str. 143

04277 Leipzig, Germany

Printing \& Binding in Germany and the Netherlands

Printed on acid-free, FSC certified and environmentally neutral paper

ISBN (Hardcover) 978-3-96627-026-7

ISBN (Softcover) 978-3-96627-027-4

ISBN (PDF) 978-3-96627-028-1 


\section{Abstract}

This master thesis provides an extensive definition of transmedia storytelling systems and the fantasy genre, besides a short overview of publishing management, technology, and marketing. The focus of this master thesis is the practical relevance of transmedia storytelling systems for fantasy franchises, such as Harry Potter, Game of Thrones, or The Lord of the Rings.

This thesis results in the perceptions that potential customers indeed consume storylines across different media types. Most of them only through media types with a low degree of participation. A smaller but significant amount of the customer consumes media types with a high degree of participation. These results are findings from a survey of more than 600 consumers surveyed of selected fantasy franchises. 



\section{Inhaltsverzeichnis}

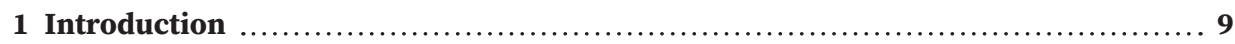

2 Overview of Publishing Technologies ….......................................... 11

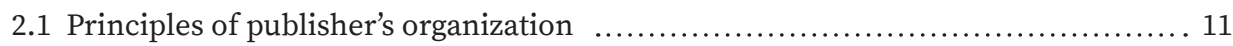

2.2 Cross-media publishing ..................................................... 12

2.2.1 Setup and Integration of a cross-media publishing system ....................... 14

2.3 Publisher's marketing .................................................................. 17

2.3.1 Publishing trademarks ............................................................. 20

2.3.2 Selection of marketing measures …........................................... 21

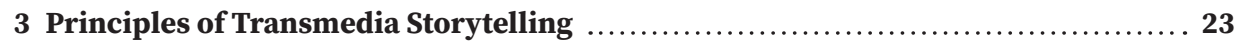

3.1 Transmediality ................................................................ 23

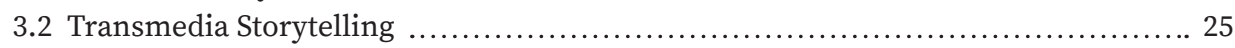

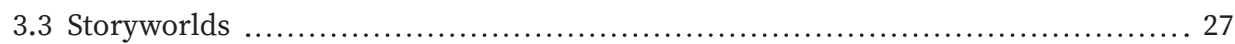

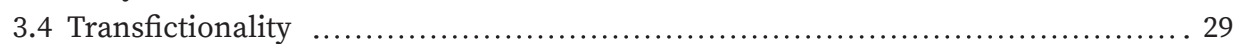

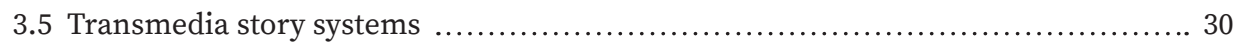

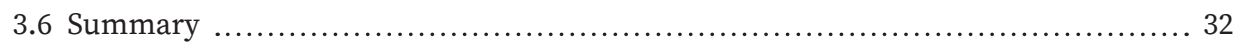

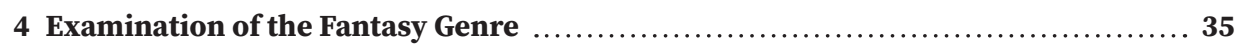

4.1 Definition of Fantasy ....................................................... 35

4.1.1 The secondary world ........................................................... 36

4.1.2 Metaphysical power ............................................................. 38

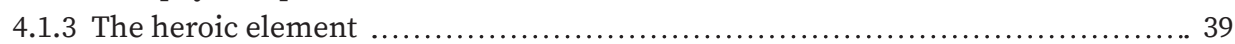

4.1.4 Demarcating Fantasy from related terms and genres ............................. 40

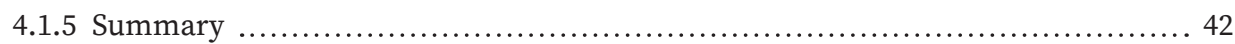

4.2 The German Fantasy market .................................................. 43

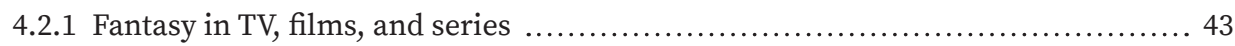

4.2.2 Fantasy in books ................................................................ 45

4.2.3 Fantasy in computer games .................................................... 46

4.2.4 In conclusion .............................................................. 49

5 Implementation of a Survey:

Consumption of the Same Fantasy Narrative in Different Media Types .......... 51

5.1 Methods and systematic ........................................................ 51

5.1.1 Description of the examples ......................................................... 53

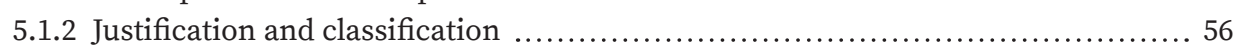

5.1 .3 Gathering of personal data ................................................ 58

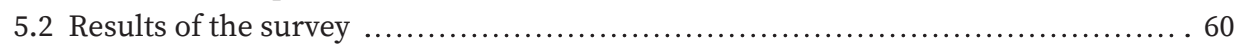


VIII Inhaltsverzeichnis

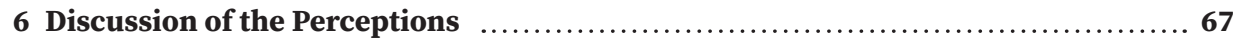

6.1 Interpretation and discussion of the survey's results ............................ 67

6.1.1 Interpretation and discussion concerning the target audience ................. 67

6.1.2 Interpretation and discussion in terms of further media consumption ............ 71

6.1.3 Interpretation and discussion in terms of the media type's potential ............... 79

6.1.4 Interpretation and discussion in terms of further results and perceptions ........ 86

6.2 Strategic Theses for Publishing Houses and Media Agencies ......................... 88

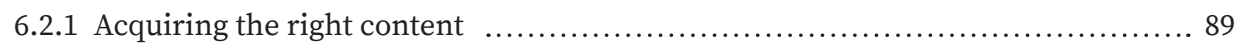

6.2.2 How to design a transmedia storytelling system? ................................ 91

6.2.3 After obtaining the right stories ........................................... 93

6.2.4 The right publishing system .................................................. 96

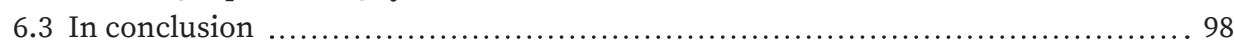

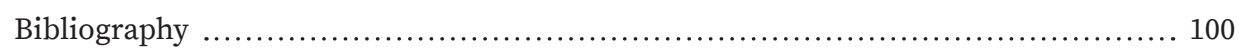

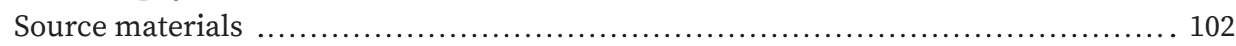

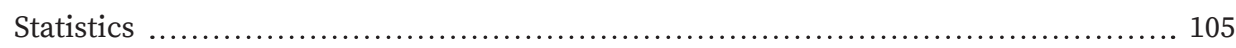

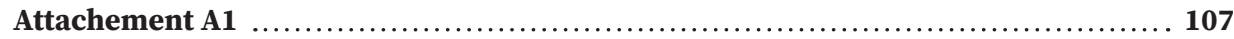

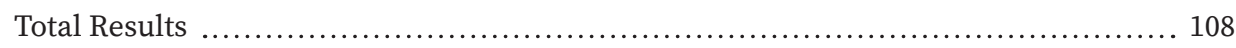

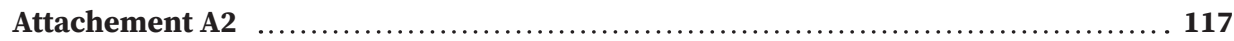

Survey's structure and results in Detail ........................................... 118 


\section{Introduction}

The global media market went through considerable changes in recent decades. On the one side, submarkets of media are in higher competition with each other. On the other side, media convergence goes on, and more submarkets meld together. In recent years, a supposed new trend has revived - transmedia storytelling. Driven by new media formats, products, and types, transmedia storytelling found back its way into cultural and commercial recognition.

Franchises like The Lord of the Rings, Star Wars, Harry Potter, Resident Evil, and The Wicher are famous examples that also rely on transmedia storytelling. Most publishers and media agencies reference such examples and remarks to include transmedia storytelling as a long term strategy for better penetration of the market and competitive advantages. Consequently, the question emerges,

- What is transmedia storytelling?

- Do customers follow a storyline across different media types?

- How far would they go?

- What content is suitable for transmedia storytelling?

- Which technologies and skills do companies need to establish a transmedia storytelling system?

This master thesis examines the structure and definition of transmedia storytelling systems, and how could publishers make use of such as a system with the current technology. As many of the mentioned examples imply, it is presumable that the fantasy genre is a suitable topic to examine transmedia storytelling. Therefore, this master thesis focuses on fantasy franchises. First, the master thesis examines the publishing industry and provides a short overview of publishing management, technologies, and marketing measures. It follows an examination of transmedia storytelling systems and particular types, forms, definitions. The third chapter contains the definition of the fantasy genre. The emphasis of the master thesis is the implementation and analysis of a survey that addresses the research questions. Lastly, the master thesis closes with advantages for publishers concerning transmedia storytelling and an approach to answering the research questions above. For a better understanding, basic knowledge of publishing technologies is recommended. 



\section{Overview of Publishing Technologies}

This chapter provides an overview of publishing technologies with a specific focus set on publishing houses - first, the publisher's types, lists, and publishing eras; then, the focus of the examination shift to cross-media publishing, media-impartial data retention, and multiple-channel publishing. The last part of this chapter examines the principles of publishing-marketing and merchandising. This chapter shall deliver the principles of publishing management and technology that are essential for the utilization of transmedia storytelling.

\subsection{Principles of publisher's organization}

Publishing houses can classify themselves by their target audience, market, structure, products, organization, and relation to the retailer and suppliers. In terms of the products, one can distinguish between book- and magazine- or newspaper-publishers. A book-publisher produces book-type media, such as printed books, electronic books, or audiobooks. In contrast, a magazine- or newspaper-publisher produces magazines, brochures, newspapers in print and electronic formats. The business of magazine/newspaper-publishers is considerably more steady and assessable than the business of book-publishers, which is more erratic in contrast. ${ }^{1}$

In terms of suppliers, one could distinguish between author-and editing-publishing houses. An author-publisher depends on an author who creates the content, such as novels. In contrast, an editing-publishing house creates a part or even the whole content on its own. ${ }^{2}$

In terms of organization and market, one could also distinguish between original and license-publishers. An original-publisher owns the original exploitation right given by the creator of the content. Opposed to a license-publisher often publishes translated issues of foreign publications. ${ }^{3}$ In terms of the target audience, one could finally distinguish between ${ }^{4}$ Special interest publishers (such as scientific publishers),

- General interest publishers (such as fiction books),

- Trade publishers (such as nursery or model railroad hobby magazines,

- and education publishers (such as textbooks).

1 Von Lucius, Wulf D.: Verlagswirtschaft (Konstanz: UVK Verlagsgesellschaft mbH, 2007) 84 et seq.

2 Von Lucius, Wulf D.: Verlagswirtschaft (Konstanz: UVK Verlagsgesellschaft mbH, 2007) 85 et seq.

3 Von Lucius, Wulf D.: Verlagswirtschaft (Konstanz: UVK Verlagsgesellschaft mbH, 2007) 88 et seq.

4 Von Lucius, Wulf D.: Verlagswirtschaft (Konstanz: UVK Verlagsgesellschaft mbH, 2007) 86 et seq. 
Every publishing house has a product line that represents the publisher's list. ${ }^{5}$ The publisher's list determines the long-term strategical management of a publisher. Besides, the publisher's line has a further dimension in width, depth, and height, which describes the number of publisher's lists within one publishing house (width), the number topics per list (depths), and the number of publications per topic (height). ${ }^{6}$ The strategical planning of the publisher's list depends on several factors, such as time, content, personal capacity, finance, competition, and the target audience. Especially in terms of competition, a publishing house has many strategic options, such as generating new innovative products, concentration on specialinterest topics, copy other publishers, cost leadership, or specific cooperation strategies. $^{7}$

Besides the properties of the publishing houses and strategic measures, the structure of the standard publishing process changed through recent years. The publishing process classifies itself in three eras, based on essential trends and innovations. In the first era, publishing 1.0 is the classic commercial process of publishing, where the publisher releases printed media products on the market, and the communication between publisher and consumer was unidirectional. In the second era, publishing 2.0 relies on desktop publishing (DTP) with the inclusion of electronic publishing systems, electronic media design, and electronic media products. Publishing 1.0 and 2.0 align processes to the particular end-products. Publishing 3.0, the third and most recent era, works orientated to processes, implements crossmedia publishing systems with the help of Web 2.0 and bidirectional communication between publisher and consumer. ${ }^{8,9}$

\subsection{Cross-media publishing}

This subchapter does a closer description of the principles from the publishing 3.0 era and, therefore, the current publishing technology systems. The major component of the current publishing technology is cross-media publishing.

Crossmedia-publishing is a specific kind of publishing process, which enables a broad automatization of the publishing process while it is addressing multiple output media. Cross-media publishing aims to implement multiple output media with a central database and a high degree of automation. ${ }^{10}$ Such a publishing process

5 Brockhaus Enzyklopädie Online: Produktionsprogramm. NE GmbH | Brockhaus, 2019. https:// brockhaus.de/ecs/permalink/4D85A2F15053536A3B03886AC755DB1C.pdf [last accessed on 19.11.11].

6 Von Lucius, Wulf D.: Verlagswirtschaft (Konstanz: UVK Verlagsgesellschaft mbH, 2007) 76 et seq.

7 Von Lucius, Wulf D.: Verlagswirtschaft (Konstanz: UVK Verlagsgesellschaft mbH, 2007) 75.

8 Publisher: Publishing-3.0-Lösungen im Überflug, https://publisher.ch/publisher-archiv-detail-2. php?t=Publishing-3.0-L\%C3\%B6sungen+im+\%C3\%9Cberflug\&read_article=8012 [last accessed on 19.11.10].

9 Publisher: Medienproduktion - quo vadis, https://publisher.ch/publisher-archiv-detail-2.php?read_ article $=8022$ [last accessed on 19.11.10].

10 Fritzsche, Hans P.: Cross Media Publishing : Konzepte, Grundlagen und Praxis (Bonn: Galileo Press 
makes publishing houses more flexible among different output media, media types, and it enables the economization of time and costs in a steady process. ${ }^{11}$ Furthermore, it supports the consistency of data and information and ensures that the same content is available on multiple media output formats. ${ }^{12}$

The typical output media formats are: ${ }^{13}$

- PDF, SGML, PostScript for print

- HTML/XML for web and e-commerce

- PDF for download from the web

- XML for further processing, such as Java.

A cross-media publishing system could also realize interchange format data for further processing on particular media workflow, such as game development.

It is crucial to mark off the term cross-media from multimedia and transmedia. The distinction of cross-media from multimedia and transmedia relies on the specific form of output media. For cross-media, the number of different output media for content matters. For multi-media, it is the number of different media types inside one document. ${ }^{14}$ For transmedia, the number of different documents of different media types for one narrative matter. ${ }^{15}$ The distinction can be better clarified by examples:

When a publishing house publishes a cookbook on a print and electronic issue, it is cross-media published. In contrast, when a publishing house publishes an electronic cookbook with tutorial videos included, but no particular print issue, it is published multimedia but not cross-media.

Therefore, for cross-media publishing, the number of media outputs, where a specific processing underlays, matter. For multimedia, the number of different media types in one document matter. In the proper sense, text and illustrations are enough to pertain as multimedia. In practice, the combination of static and dynamic media components is the factor in classifying a document as multimedia. Text and illustration are both static media types. In contrast, videos, music, and speech are dynamic media types. ${ }^{16}$

$\mathrm{GmbH}, 2001)$ page 119.

11 Albert Bauer Companies: Crossmedia Marketing. Albert Bauer Companies GmbH \& Co. KG, 2019. https://www.albertbauer.com/crossmedia-marketing/ [last accessed on 19.11.10].

12 Managementportal: Cross Media Publishing im Praxiseinsatz: Viele Vorteile bei wenig Aufwand. Managementortal.de, Recklies Management Project GmbH, 2015. https://www.managementportal. de/inhalte/artikel/fachbeitraege/14-marketing/519-cross-media-publishing-im-praxiseinsatzviele-vorteile-bei-wenig-aufwand.html [last accessed on 19.11.10].

13 Fritzsche, Hans P.: Cross Media Publishing: Konzepte, Grundlagen und Praxis (Bonn: Galileo Press $\mathrm{GmbH}, 2001)$ page 120.

14 Jakubetz, Christian; Langer, Ulrike; Universalcode Journalismus im digitalen Zeitalter (München: euryclia, 2011) page 19 et seq.

15 See chapter 3, page 19.

16 Brockhaus Enzyklopädie Online: Multimedia. NE GmbH | Brockhaus, 2019. https://brockhaus.de/ 


\subsubsection{Setup and Integration of a cross-media publishing system}

The setup of a cross-media publishing system depends on the kind and properties of the output media documents. The publisher should clarify beforehand: ${ }^{17}$

- Content,

- Type of media output

- Number of media types gathered in one output,

- Quantity of media editing in a specific period,

- Customer (for example parents, grandparents and families),

- Consumer (children before enrollment),

- Purpose of the final publication,

- Number of output channels

- Design of each media

- Possibility of changing and enhancing the system

- Know-how and training of the employees.

Once a publisher has gathered these pieces of information, it can deduce the requirement of data retention and the suitable choice of software and methods. The basis or centrum of a cross-media system is data retention. For a publishing system with various output media ${ }^{18}$ and high requirement flexibility of printed outputmedia selection, ${ }^{19}$ it is advisable to hold the data retention "media-impartial". Media Impartial data retention aims for a free from the purpose of use data exchange and data handling. This aim requires the separation of structure, content, and design. ${ }^{20}$

The content could be saved as unformatted text-files, in an image, video, or music database. The structure can be saved as a set of semantic markups based on the end product's metadata. The design could be saved as a set of formatting instructions in the form of CSS files or paragraph- and character style files. This separation enables a flexible transition of the content into different media. For every end-product optimally exists structure and design formatting instructions. The publishing process of various output media out from a single data source is called Single-Source(Multiple-Channel-) Publishing in practice. ${ }^{21}$

ecs/permalink/3887C77FD2797513924048AB847E44F4.pdf [last accessed on 19.11.11].

17 Fritzsche, Hans P.: Cross Media Publishing: Konzepte, Grundlagen und Praxis (Bonn: Galileo Press GmbH, 2001) page 131.

18 Fraunhofer: Grundlagen der medienneutralen Datenhaltung. Fraunhofer-Publica - Publication Database of the Fraunhofer-Gesellschaft, 1996. http://publica.fraunhofer.de/documents/ PX-16486.html [last accessed on 19.11.11].

19 Medien Community: Medienneutrale Daten, https://mediencommunity.de/content/u7-medienneutrale-daten [last accessed on 19.11.11].

20 Bühler, Peter; Schlaich, Patrick; and Sinner, Dominick: Crossmedia Publishing | Single Source-XMLWeb-to-Print (Berlin: Springer Nature, 2019), page $2-4$.

21 Bühler, Peter; Schlaich, Patrick; and Sinner, Dominick: Crossmedia Publishing | Single Source-XMLWeb-to-Print (Berlin: Springer Nature, 2019), page 2. 


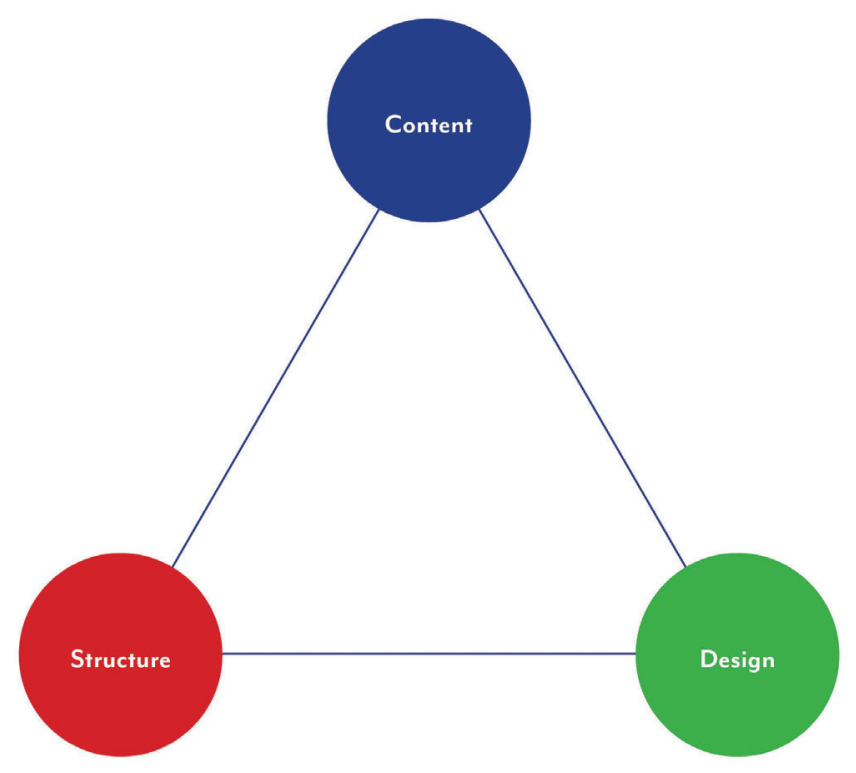

Figure 1 Separation of structure, content, and design (Source: Personal collection).

The conventional method of single-source-publishing is the use of the eXtensible Markup Language, abbreviated as XML. XML is a free, platform-independent, and application-independent meta language. XML is the basis for creating applicationspecific markup languages that describe the structure of particular content. ${ }^{22}$ In practice, a lot of XML based markup languages are available for free, such as DocBook, the Journal Article Tagging Suite (JATS), the Book Interchange Tagging Suite (BITS) and many more. All given examples come from the scientific publishing subject. ${ }^{23}$

The XML markups stand beside the text-content or hypertext references in the case of images, music, or videos, inside the XML-file. ${ }^{24}$

The design of an end-product relies on formatting instructions inside a stylesheet, such as Cascading Stylesheet (CSS), the eXtensible Stylesheet Language (XSL), paragraph and character stylesheets, and many more. Attention should be paid to the factor that XSL is not a stylesheet that contains designing instructions. XSL filters, sorts, and re-arranges the elements of an XML file, and addresses the

22 Fritzsche, Hans P.: Cross Media Publishing: Konzepte, Grundlagen und Praxis (Bonn: Galileo Press $\mathrm{GmbH}, 2001)$ page 123.

23 Selfhtml: XML/Dialekte, https://wiki.selfhtml.org/wiki/XML/Dialekte [last accessed on November 11, 2019].

24 Bühler, Peter; Schlaich, Patrick; and Sinner, Dominick: Crossmedia Publishing | Single Source-XMLWeb-to-Print (Berlin: Springer Nature, 2019), page 18 et seq. 
output media format, such as HTML or PDF. In this case, XSL contains transformation instruction and is also called XSL-T. In contrast, CSS or Print-CSS contains formatting objects that define the visual-design of the output media. When one wants to use XSL for a visual-design as well, then one must use XSL-formatting objects. This markup is an XSL application for particular style formattings. ${ }^{25}$

Figure 02 displays a sample cross-media system for fantasy content. The example publishing house publishes an online wiki with entries for every imaginary character and creature of a fantasy novel, consisting of text, images, and explanation video for every entry. Besides the online wiki, the example publishing house produces a printed lexicon that contains the same content as the online wiki, just without the videos.

The XML files contain the text content, positioned linkings to corresponding images and videos. XSL-file A selects all elements from the XML-file that are relevant for the print-production. Besides, XSL-file B selects all relevant elements for the web-publication. The CSS file delivers the particular formatting instructions for the web-publication. For he print-publication, the formatting instructions stand in the Print-CSS. The XSL processor, a software that drives the conversion and transformation, generates the HTML and printable PDF file. The printable PDF-file goes for further processing to the printing house. The HTML file can now get unlocked for online publication.

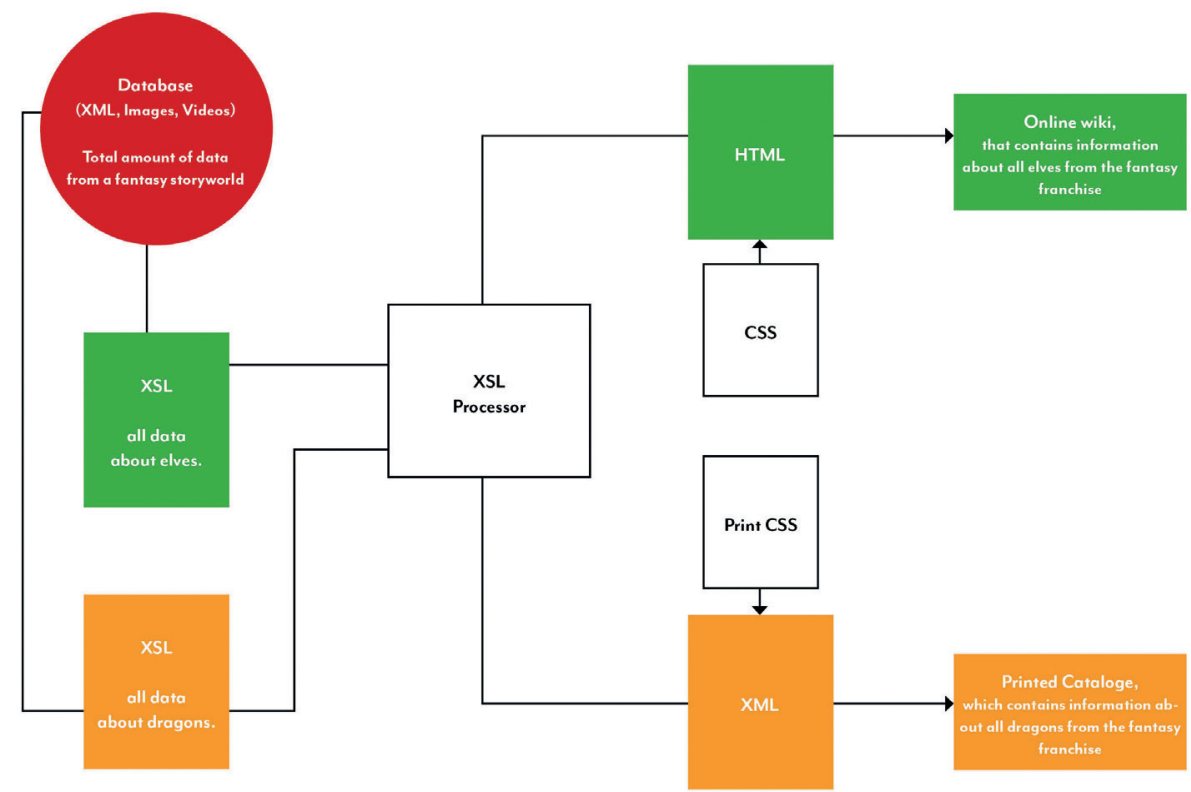

Figure 2 Sample cross-media system for fantasy content (Source: Personal collection).

25 Selfhtml: XML/XSL/XSLT, https://wiki.selfhtml.org/wiki/XML/XSL/XSLT [last accessed on November 11, 2019]. 
Such a cross-media system could be integrated into a content management system (CMS). A content management system enables the central control of all relevant processes. It implements the separation of content, structure, and design processes, and keeps it a uniform system frame. Besides, it enables the inclusion of authors, editors, designers, programmers, producers, and project coordinators within a uniform company system. New content can be edited into the system directly, as well as output media converted from it. ${ }^{26}$

Furthermore, two regular XML workflows exist. In the first workflow, the producer executes the publishing process in a traditional way and converts the publication to XML after the process is finished. XML-Last is the name of this sample workflow. In contrast, the XML-First sample workflow requires XML-editing before the publishing process starts. The XML-First workload has a more extended timeto-market factor than the XML-Last workflow. However, the flexibility in terms of further processing into different output versions and media referencing is considerably higher in the case of XML-First than XML-Last. ${ }^{27}$

\subsection{Publisher's marketing}

This subchapter gives a short introduction to the publisher's marketing, with a particular focus on book publishers. The subject of general and publishing-related marketing is comprehensive. Therefore, this master thesis gives just a short overview of this topic concerning further perceptions and theses of this master thesis.

The entrepreneurial thinking of the publishing industry, especially for the publishing of books, underwent considerable changes from the recent years of the late $20^{\text {th }}$ century. Specifically, the shift of two mindsets triggered transitions that affect the whole branch. ${ }^{28}$

The first shift of mindset is that marketing should not be seen as a separated function of a company. Marketing affects all business activities, and therefore its responsibility should run through every division of a company. ${ }^{29}$

The classic value chain of publishing was deduced from this entrepreneurial thinking. ${ }^{30}$ However, this value chain has lost its topicality because publishing processes have changed considerably in recent years, such as trends like cross-media, web-to-print, self-publishing, any many more emerged. The only constant of this value chain is the worth of content, which is the only thing that matters from the view of the consumer. ${ }^{31}$

Bühler, Peter; Schlaich, Patrick; and Sinner, Dominick: Crossmedia Publishing | Single Source-XMLWeb-to-Print (Berlin: Springer Nature, 2019), page 2.

27 Pagina: XML first - XML last https://www.pagina.gmbh/xml-hintergruende/crossmediales-publizieren/teil-ii-die-technik/xml-in-der-verlagspraxis/der-weg-zu-xml/xml-first-xml-last/ [last accessed on November 11, 2019].

28 Huse, Ulrich: Verlagsmarketing (Frankfurt am Main: Bramann, 2017) page 13 et seq.

29 Drucker, Peter: The Practice of Management (Düsseldorf: Econ, 1954).

30 Wirtz, Bernd W.: Medien und Internetmanagement (Wiesbaden: Gabler, 2009).

31 Huse, Ulrich: Verlagsmarketing (Frankfurt am Main: Bramann, 2017) page 15. 
This perception leads over to the second shift of mindset, which describes the alignment of the publisher's list to a selection of content which the consumers require, instead of a selection of content that the publishers preset. The old mindset is recognizable by a citation of the publisher Kurt Wolff, who said that two kinds of publishers exist: One kind that provides books that the consumers should read and the second kind of publishers that provides books that the consumers want to read. The second category of publishers, who run after the public taste, do not count for him. ${ }^{32}$

However, the pandering to the public and, therefore, a paradigm shift happens. For modern publishers, the customer focus matters, and not cultural commitment. ${ }^{33}$ The customer focus divides into four different perspectives of marketing: ${ }^{34}$

- The customer's point of view, which describes that all publisher's activities should also be seen from the customer's point of view. From the particular perceptions, it deduces indications for the publisher's list, packaging, distribution, pricing, and many more.

- The customer wishes. Before a publisher can produce the right product, he or she should recognize the attitude, habit, behavior, and requirements of the customers

- The customer value, which means to know the claims and standards of the customers and to keep these in mind by the conception of products.

- The solution focus. This perspective bases on the previous ones and means to offer products that solve the problems and issues of the consumer.

- Sales arguments also base on previous perceptions. If the publisher knows the customer value and wishes, he or she gains a proper occasion to communicate with the customers.

However, a trade obstacle is that the customers take the fundamental value of a publication for granted. First, with a specific feature, customer satisfaction accrues. Customer loyalty accrues with the additional offer of added value, which could also be described as delightful requirements. ${ }^{35}$ Delightful requirements are attributes for which costumers do not bargain and distinguish the product from the competition. ${ }^{36}$

Before a publisher can decide from the customer's point of view, he or she must ascertain the target audience of his or her proposals. The problem of ascertaining a target audience for books is that books have a relatively short product life cycle. The product life cycle of a book is often shorter than the time exposure for a target

32 Wolff, Kurt: Autoren/Bücher/Abenteuer. Beobachtungen und Erinnerungen eines Verleger (Berlin: Wagenbach, 1965).

33 Huse, Ulrich: Verlagsmarketing (Frankfurt am Main: Bramann, 2017) page 14 et seq.

34 Huse, Ulrich: Verlagsmarketing (Frankfurt am Main: Bramann, 2017) page 16 et seq.

35 Huse, Ulrich: Verlagsmarketing (Frankfurt am Main: Bramann, 2017) page 16 et seq.

36 Noriaki, Kano, N. Seraku, F. Takahashi, S. Tsuji: Attractive Quality and Must-be Quality. In: Journal of the Japanese Society for Quality Control. (Wuhan: Scientific Research Publishing, 1984) page. 147 et seq. 
audience investigation. Therefore, publishers must recourse to other methods, such as Personas, "Sinus Milleus", or Social Media Monitoring, for ascertaining the suitable target audience. ${ }^{37}$

After considering the target audience and customer's point of view, the publishing house can start with the planning, implementation, and control of marketing tasks summarized as marketing management. A mix of various aspects decides whether a product got purchased or not. Therefore, Neil H. Borden defined marketing twelve policy-related instruments. These instruments, named marketing-mix, were reduced of four most relevant instruments (4 P's): ${ }^{38}$

- Product - properties of products, and structure of the product line (publisher's list)

- Price - for what price and conditions a product is offered

- Place - distribution channels for each product

- Promotion - which measures are suitable to reach the target audience and to inform about the product's properties sufficiently

These four instruments work as assistance to undertake sufficient marketing management. Competitive advantage and commercial success do not rely on product development, multi-channel distribution, and competitive conditions exclusively. Just with the help of the promotion component, a company can achieve its marketing aims. ${ }^{39}$

In practice, a publishing house defines, based on its annual program, a marketing budget and, consequently, a marketing schedule. Commonly, a publisher has two kinds of books on his or her list, new titles and backlist titles. Most of the budget flows into the promotion measures for new titles. Besides, parts of the budgets flow into

- Topic-orientated promotion measures (such as holidays, hobbies, particular events),

- Author-orientated promotion measures (such as birthdays or awards),

- or publisher-orientated promotion measures (such as rebrandings or anniversaries).

Just a small piece of the marketing budget remains for the backlist titles. ${ }^{40}$

Such a publisher's marketing plan discusses five questions of "what", "who", "where", "how", and "when". The publisher's list answers to the question "what", the definition of the target audience answers the question "who", and the marketing

37 Huse, Ulrich: Verlagsmarketing (Frankfurt am Main: Bramann, 2017) page 18 et seq.

38 Borden, Neil H.: The Concept of the Marketing-Mix. In: Science in Marketing (New York: John Wiley, 1964).

39 Huse, Ulrich: Verlagsmarketing (Frankfurt am Main: Bramann, 2017) page 21 et seq.

40 Huse, Ulrich: Verlagsmarketing (Frankfurt am Main: Bramann, 2017) page 22. 
budget decides about the remaining questions. ${ }^{41}$ Furthermore, the answering of these questions leads over to the strategy concerning the sales intermediary. In theory, two ways exist for such a measure concerning the sales intermediary - the pullor push-marketing strategy. In case of push-marketing, the publisher tries with a more frequent presentation of goods on the point of sales to encourage more people to purchase the product. This method is advisable for best-seller marketing, and the publisher should be sure about the sales hit because it requires a high budget. In a literal sense, the publisher pushes the items into the bookstore. In contrast, pullmarketing is a strategy where the publisher tries to encourage people to demand a particular product, with the help of several promotion measures. This method is advisable for novel-series, such as Harry Potter, and contains a lesser risk for loss of profit than push-marketing. In practice, many publishers use a combination of both strategies. ${ }^{42}$

\subsubsection{Publishing trademarks}

A trademark is a distinctive symbol that is rooted inside the mind of the customer. ${ }^{43}$ Furthermore, a trademark describes a service that delivers a faculty of discrimination and a promise of quality by a specific marketing strategy. It should fulfill customer expectations of the relevant target audience and achieve long term success in a particular market. ${ }^{44}$

In conclusion, a trademark has an individualization/discrimination function, an identification function, and a promising function..$^{45}$

In publishing, there is a consensus about the factor that customers are just purchasing single titles. Merely a specific author or novel series could work as trademarks, such as Steven King or The Three Investigators, but rarely the publishing house. Nevertheless, some publishers establish themselves as a publisher's trademark, such as Langenscheidt or Diogenes. The basis for establishing a publisher's trademark is clear communication with the publisher's environment, consistency of its public image, and frim business ethics and policies. These factors build a corporate identity. ${ }^{46}$ An essential element of corporate identity is the corporate design, which describes the appearance of a company. It includes the total amount of all visualized promotion and packaging components, and it emerges from the corporate identity. Therefore, it transports the corporate identity and does not define it. ${ }^{47}$

41 Huse, Ulrich: Verlagsmarketing (Frankfurt am Main: Bramann, 2017) page 22 et seq.

42 Huse, Ulrich: Verlagsmarketing (Frankfurt am Main: Bramann, 2017) page 23 et seq.

43 Meffert, Heribert: Marketing. Grundlagen marktorientierter Unternehmensführung. Konzepte Instrumente - Praxisbeispiele (Wiebaden: Gabler, 2000).

44 Bruhn, Manfred: Was ist eine Marke? Aktualisierung einer Markendefinition (Gräfeling: Gesellschaft zur Erforschung des Markenwesens e.V., 2002).

45 Huse, Ulrich: Verlagsmarketing (Frankfurt am Main: Bramann, 2017) page 28.

46 Huse, Ulrich: Verlagsmarketing (Frankfurt am Main: Bramann, 2017) page 33 et seq.

Domizflaff, Hans: Die Gewinnung des Vertrauens (Hamburg: Marketing Journal, 1982). 
Besides a distinct corporate identity and consistent corporate design, the publisher should create a promise of quality, price, content, or topic to create a consistent and unique publisher's list. The content of a publication establishes its identity. Therefore, it is not a consumer product but a product of experience. For non-fiction books, the quality of the content is more appreciable than for fiction books. So, in this case, the customer must give the publishing house, and its book offers a credit of trust. By the effect of customer satisfaction and customer loyalty, the customer will give credit of trust generously all along. ${ }^{48}$

Lastly, there are several levels of trademarks in publishing, which are displayed in the table below.

Tab. 1 Levels of trademarks

\begin{tabular}{lll} 
Trademark Level & In Publishing & Examples \\
\hline Single brand & Authors and protagonists & Steven King, Harry Potter \\
\hline Family of brands & $\begin{array}{l}\text { Publisher's list and novel } \\
\text { series }\end{array}$ & Hobbit press by Klett Cotta \\
\hline Umbrella brand & Publishing house & Langenscheidt
\end{tabular}

\subsubsection{Selection of marketing measures}

Publishers distinguish between two types of marketing, trade marketing, which addresses the sales intermediaries, such as bookstores, and customer marketing, which addresses the customers. This subchapter examines two measures of customer marketing that are essential for this master thesis.

Many possible measures for customer marketing are available to the publisher, such as marketing events, customized marketing, ads marketing, merchandising, and cross-marketing. The last two measures get a closer examination.

Merchandising is an umbrella term for all measures that support the sales pitch. However, merchandising could also describe a transition of content, symbols, and brands to another product type. In this sense, merchandising is a form of secondary publication rights, where a third party has the authority to use figures, designs, symbols, and signs for its products. In other words, it is licensing. For example, a cupsproducer gains the authority to print the emblem of Griffyndor (a school-house from Hogwarts in the Harry Potter narrative) on their cups. The aim of merchandising is a positive image-transfer of a brand, that causes a better sale for the original product as well as for the merchandising product. ${ }^{49}$

48 Huse, Ulrich: Verlagsmarketing (Frankfurt am Main: Bramann, 2017) page 28 et seq.

49 Huse, Ulrich: Verlagsmarketing (Frankfurt am Main: Bramann, 2017) page128 et seq. 
Especially when books achieve a high involvement of their readers into an imaginary storyworld, the customer's wish appears to transport pieces of this secondary world into the primary world (see chapter 4.1.1.). ${ }^{50}$

Cross-marketing is a measure where independent companies start temporary cooperation. This form of marketing aims for image transfer, better sales by delightful surprises and prices, increased attention for both brands, increasing the target audience, competition advantages, and more effortless penetration of the market. Such a cross-marketing appears in the product policy and the promotion policy. In the product policy, the companies could do a

- Co-branding (creating a single product that combines the expertise of both companies),

- Product bundling (combines proposal of two or more products), or

- Ingredient branding (usage of specific ingredients within the end product). ${ }^{51}$

In the promotion policy, the companies could realize a

- Cross-promotion (bilateral advertising),

- Couponing (a particular form of cross-promotion, where the customer gets a coupon for a product of another company),

- Cross-advertising (collective advertising), or

- Cross-referencing (the companies recommend each other products or services). ${ }^{52}$

50 Heldmaier, Christian: Merchandising für Bücher ohne Filmanbindung. Grundlagen, Chancen und Umsetzungensmöglichkeiten für Verlage. Thesis (Stuttgart: Hochschule der Medien, 2011).

51 Huse, Ulrich: Verlagsmarketing (Frankfurt am Main: Bramann, 2017) page 133.

52 See fn. 51. 


\section{Principles of Transmedia Storytelling}

The following chapter examines the question of what transmedia storytelling exactly is and which forms and comp onents it can adopt and contain. In contrast to the previous chapter, this topic is not wholly located in the field of media science, media management, or publishing engineering. Transmedia storytelling belongs originally to the field of narratology and literary criticism, but it represents an interface between these subjects. In other words, the description of the phenomenon transmedia storytelling belongs to narratology, but the implementation of this phenomenon belongs to media management and publishing engineering.

\subsection{Transmediality}

First, I will define and elucidate the term "transmediality" and its different forms. This examination is essential to gain a better understanding of what transmedia storytelling accurately describes and contains.

Transmediality describes a media-unspecific and itinerant phenomenon. In other words, the appearance, transition, or implementation of the same content or topic in different media. ${ }^{53}$

In the field of narratology, two forms of transmediality have been established: the East Coast and West Coast transmediality. These two terms were proposed by Brian Clark, the CEO, and Founder of GMD Studios. ${ }^{54}$ West Coast transmediality stands for commercial franchises of the "Hollywood" entertainment industry, such as The Lord of the Rings, The Matrix, or Harry Potter. East Coast transmediality means everything that is not West Coast transmediality. The independent narratologist Marie-Laure Ryan titled the following four possible and popular forms of East Coast transmediality: ${ }^{55}$

\section{Transmedia journalism}

Transmedia journalism could be treated as a subject- or theme-specific archive or database. It could be a website or an online media library, which contains multiple media objects, like text, videos, oral testimonies, and many more. These media objects must be located on the same medium, which is accessible to a public

53 Meyer, Urs/Simanowski, Roberto/Zeller, Christoph: Transmedialität. Zur Ästhetik paraliterarischer Verfahren (Göttingen: Wallstein, 2006).

54 Clark, Brian: Reclaiming Transmedia Storyteller (Facebook, 2011), (https://www.facebook.com/ notes/brian-clark/reclaiming-transmedia-storyteller/10150246236508993/ [last accessed on 2019.07.04].

55 Ryan, Marie-Laure: “Transmedia narratology and transmedia storytelling”, In: Artnodes no. 18 (Barcelona: Universitat Oberta de Catalunya, 2016) page 1-10. 
audience, and they should belong to the same topic. For example, a TV broadcaster hosts a website for the next olympic games in Tokyo, where a lot of videos, text interviews, and audio files get uploaded.

\section{Installations}

Transmedia installations describe the simultaneous use of multiple media objects and media delivery systems. For example, the $360^{\circ}$ panorama installations from Yadegar Asisi, which delivers at least three types of media, that the visitors use simultaneously: the huge $360^{\circ}$ photomontage, music, or atmospheric voices, and an information map. ${ }^{56}$

\section{Alternate Reality Games (ARGs)}

Alternate Reality Game is an umbrella term for a marginal phenomenon that emerged through media convergence. It could also be called "collaborative story" "Interactive Narrative" 58 , or "Story Game" 59 . In this game, the media consumer reconstitutes a story through various media, like a jigsaw puzzle. The single parts of an ARG must be used mostly in the right order and cannot stand alone to build a selfcontained story. So they could be a part of transmedia storytelling system. However, an ARG could not be stand-alone transmedia storytelling system.

\section{Augmented books}

An augmented book consists of the central physical part, possibly multimodal documents, and additional digital content that could be called through an app or something else. An example is Night Film by Marisha Pessl (2013). This book contains multimodal documents like printed screenshots of websites, and the reader can scan pictures with his smartphone or tablet to unlock additional text, video, and audios. ${ }^{60}$ West Coast transmediality comprises business practices of entertainment companies like turning novels to films, computer games, inspiring films, comics inspiring films, and vice versa. Such retellings and adaptions always appear when a narrative achieves a certain degree of cultural recognition. This phenomenon is what most people understand under the term Transmedia storytelling.

However, this is only a superficial view of a high contextual topic. In the following paragraphs, I will picture to picture the exact definition and subject of Transmedia storytelling.

56 See Example on offical website of Asisi: https:/www.asisi.de/homepage/ [last accessed on 2019.08.11].

57 Thompson, Brooke: Alternate Reality Gaming - A Definition, http://www.argology.org/_what-is-anarg/ [last accessed on 2019.08.11].

58 Dombrowski, Caroline/Kim, Jeffrey/Lee Elan/Thomas Timothy: "Storytelling in new media: The case of alternate reality games, In: First Monday” Vol. 14, No. 6 (Illinois: University of Illinois, 2009).

59 Hon, Dan: Everything you know about ARGs is WRONG, https://www.sixtostart.com/onetoread/2008/everything-you-know-about-args-is-wrong/ [last accessed on 2019.08.11].

60 See Example on Wikipedia: https://en.wikipedia.org/wiki/Night_Film:_A_Novel [last accessed on 2019.08.11] 


\subsection{Transmedia Storytelling}

As a starting point, I will quote the definition by Prof. Henry Jenkins, director of the MIT Comparative Media Studies Program and forerunner of investigating media convergence and transmedia storytelling:

"Transmedia storytelling represents a process where integral elements of a fiction get dispersed systematically across multiple delivery channels for the purpose of creating a unified and coordinated entertainment experience. Ideally, each medium makes its own unique contribution to the unfolding of the story." 61

In other words, transmedia storytelling is a process which belongs to a narrative, so big that it cannot be distributed by only one type of media. Marie-Laure Ryan describes two poles, with gradations in between, where a case of transmedia storytelling could appear: ${ }^{62}$

A kind of snowball effect marks the first pole. A particular story achieves so much cultural recognition that it randomly spawns various prequels, sequels, fanfictions, and transmedia adaptions.

The second pole is a transmedia conception from the beginning. In the form of a project, the narrative gets developed through various media. The whole storyworld turns into a commercial franchise, aims of getting a broader audience, and accordingly long-time loyalty.

The second pole of transmedia storytelling raises the question of the relationship of the "integral elements of a fiction" that "get dispersed systematically across multiple delivery channels." Such relation is pictured by two models: ${ }^{63}$

First: The parts fit together and build a whole story, which is more than the sum of its parts. The consumer must gather all parts to get a satisfactory experience, by following an arc that leads from exposition to complication to resolution. The consumer must follow the whole arc to catch the entire story. These single parts cannot stand alone.

Second: The parts of the whole story are held together by a common frame that is called the storyworld. Every part tells a relatively self-standing story. There are bigger and smaller parts of the story. The more significant elements should be consumed before the smaller ones because they provide a broad widescale background. Such a significant element is called "Mothership." It is not necessary to consume all elements to get a satisfactory experience. Every element should deliver its own

61 Jenkins, Henry: Transmedia Storytelling 101, (The Official Weblog of Henry Jenkins, 2007), http:// henryjenkins.org/blog/2007/03/transmedia_storytelling_101.html [last accessed on 2019.08.19].

62 Ryan, Marie-Laure: “Transmediales Erzählen im Zeitalter der Medienkonvergenz”, In: "Medien. Erzählen. Gesellschaft” (De Gruyter: Berlin, 2013) page 89.

63 Ryan, Marie-Laure: “Transmedia narratology and transmedia storytelling”, In: Artnodes no. 18 (Barcelona: Universitat Oberta de Catalunya, 2016) page 1-10. 
satisfactory experience, but the more elements the users consume, the more they gain knowledge of the whole storyworld.

The first model is like a puzzle or a paper chase, and the satisfactory entertainment experience depends on whether the media-consumer gathers all parts of a story in by the right order.

The second model could be described as a story collection of the same world or topic. First, the media-consumer needs to get familiar with the storyworld-background by using the "mothership", and then the consumer can get a satisfactory entertainment experience by every single part of the storyworld. This model (second pole + second relation model) of transmedia storytelling is possibly the most practiceoriented one. Many successful franchises, such as the Storyworlds of J.R.R. Tolkien (The Lord of the Rings/The Hobbit), J.K. Rowling (Harry Potter/Fantastic Beasts) or G.R.R. Martin (A Song of Ice and Fire/Fire and Blood) reveal traits of this model. However, in this case, transmedia storytelling would be a misnomer, and the phenomenon should be called transmedia world-building. ${ }^{64}$

Furthermore, it is essential to comment on the distinction of transmedia storytelling from adaptions. Both create a bridge across different media, but adaptions are simply representing an already existing story rather than expanding and annotating a fictional word, as it applies for transmedia storytelling. ${ }^{65}$ In other words, adaptions are transmedia, but there is no storytelling. Every adaption makes additions to or reinterpretations of the original story, depending on its output-media requirements, that may reshape our understanding of what happened in the original story. This fact is what Jenkins called "additive comprehension"66, which may not be the same as an extension of the fictional world.

Nevertheless, adaptions and retellings are part of transmedia systems and the backbone of transmedia storytelling. They enable people to relive and revisit stories in a different way. ${ }^{67}$

The Lord of the Rings film trilogy, which was produced by Peter Jacksons and released in the years from 2001 until 2003, are adaptions of the books from J.R.R. Tolkien. The films widely follow the story of the books with a few additions, cuts, and changes.

In 2014, Monolith Productions released the video game Middle-Earth: Shadow of Mordor, which story takes place between the events of The Lord of the Rings and its prequel The Hobbit. The story of the video game illuminates the fate of some characters that are mentioned in The Lord of the Rings, but they are not a significant part of its original story. So, the video game expands the whole storyworld of The Lord of

64 Ryan, Marie-Laure: “Transmedia narratology and transmedia storytelling”, In: Artnodes no. 18 (Barcelona: Universitat Oberta de Catalunya, 2016) page 1-10.

65 Jenkins, Henry: The Aesthetics of Transmedia: In Response to David Bordwell (Part One), (The Official Weblog of Henry Jenkins, 2009), http://henryjenkins.org/blog/2009/09/the_aesthetics_of_ transmedia_i.html [last accessed on 2019.08.23].

66 See Fn. 64.

67 Ryan, Marie-Laure: “Transmedia narratology and transmedia storytelling”, In: Artnodes no. 18 (Barcelona: Universitat Oberta de Catalunya, 2016) page 1-10. 
the Rings. This process is what we call transmedia storytelling. The storyworld got expanded through different media.

Transmedia storytelling has gained much attention in the past years and was treated like a modern phenomenon, but it is an already known phenomenon that could be traced back through human history. For example, narratives from Greek mythology have got distributed through various media and channels, like sculpting, architecture, drama, and epos. A further example is narratives from the bible, that were told by preachments, altarpieces, church-windows, and passion plays because many people were not able to read in medieval times. ${ }^{68}$

The new discourse of transmedia storytelling in modern days could be induced by the appearance of new media types, a new configuration of media systems, and a more participatory audience. ${ }^{69}$

\subsection{Storyworlds}

As transmedia storytelling was defined in the previous chapter, the term storyworld was mentioned frequently. This chapter clarifies what a storyworld is and which components belong to a storyworld.

A storyworld could be defined as a mental representation of the world where the narrative takes place. Because a transmedia narrative could be fictional as well as non-fictional, it is suggested to avoid the term "fiction-world." Ryan claims that a storyworld is more than a static container for the events that happen in the story; it is more like a mental simulation of the story plot. ${ }^{70}$ Furthermore, she suggests the definition of a static and dynamic component of storyworlds: ${ }^{71}$

\section{Static components}

1. Inventory of beings whose existence is tacitly assumed

2. The folklore that belongs to these beings

3. A space with geographic features

4. Several principles

5. Several social rules and worths

\section{Dynamic components}

1. Physical events that affect existing things

2. Mental events that provide meanings to physical events (for example motifs and emotional relationships

68 Ryan, Marie-Laure: “Transmediales Erzählen im Zeitalter der Medienkonvergenz”, In: "Medien. Erzählen. Gesellschaft”' (De Gruyter: Berlin, 2013) page 88.

69 Jenkins, Henry: The Aesthetics of Transmedia: In Response to David Bordwell (Part One), (The Official Weblog of Henry Jenkins, 2009), http://henryjenkins.org/blog/2009/09/the_aesthetics_of_ transmedia_i.html [last accessed on 2019.08.23]

70 Ryan, Marie-Laure: “Transmediales Erzählen im Zeitalter der Medienkonvergenz”, In: “Medien. Erzählen. Gesellschaft”' (De Gruyter: Berlin, 2013) page 90 et seq.

71 See fn. 69. 
An alternative approach for storyworld components is given by Lisbeth Klastrupp and Susana Tosca, which defined three core features of transmedia worlds: ${ }^{72}$

- Mythos - The determination of conflicts and battles of the world that expose its beings. It also contains specific lore about items and creatures that are unique to this world.

- Topos - The setting of the world in a historical period and with detailed geography.

- Ethos - The explicit and implicit ethics of the world.

Component one, three, and four of Ryans approach correspond with Topos. Component two corresponds with Mythos and component five with Ethos. In contrast to Ryans approach, there are no dynamic components defined.

The further course of this master thesis sticks to the approach of Marie-Laure Ryan, because the addition of events within the storyworlds makes it more vivid and closer to reality, and is, therefore, more in line with perceptions from the next chapter (Chapter 4 - Examination of the fantasy genre).

Three possible relations exist between a storyworld and several documents (e.g., text-documents):

\section{One-to-one relation:}

In this case, a document designs exactly one storyworld and represents the only access to it. This relation is not possible in real life because various recipients build different mental models of the storyworld. Maybe the recipients build the same mental models of the events within the storyworld, but for sure, in different visualizations and interpretations.

\section{One document - various worlds relation:}

This relation is present when the document is uncertain in a way that every recipient builds another storyworld. For example, video games that adapt a story while depending on the choices of the player.

\section{Various documents - one world relation:}

In this case, various documents design the same storyworld. This relation fits the concept of transmedia storytelling. However, this relation could also be criticized by the question of whether the various documents design the same world or just similar worlds, depending on the recipient's mental model.

This concept raises the question of the relation between the various documents that contain the same world - in the case of this master thesis - especially for fictional fantasy worlds. The relations between various documents or media that contain the same world will be elucidated in the next subchapter by the concept of transfictionality.

72 Klastrup, Lisbeth/Tosca, Susana: “Transmedial Worlds - Rethinking Cyberworld Design”, In: Center for Computer Games Research (Copenhagen: IT University of Copenhagen, 2014) page 5. 


\subsection{Transfictionality}

The term transfictionality was defined by Prof. Richard Saint-Gelais. Transfictionalty refers to the sharing of fictional elements in various documents that belong to the same medium, typically narrative literature. ${ }^{73}$ Transmedia storytelling could be seen as a particular form of transfictionality where fictional elements roam through multiple documents of different media types. These fictional elements could be characters, fantastic locations, events, or even the whole fictional world. ${ }^{74}$

In other words, transfictionality links various documents that contain the same fictional world. This linking relies on three crucial operations that were explained by Lubomír Doleže $l^{75}$ and Marie-Laure Ryan: ${ }^{76}$

\section{Extension:}

New stories will be added to the original fictional world while respecting its established parameter. For example, telling new stories about secondary characters or extending the time of the original through prequels and sequels.

\section{Modification/displacement: ${ }^{77}$}

The plot of the original narrative going to be changed essentially - for instance, giving new endings or changing the relationship between fictional characters.

\section{Transposition:}

Transporting the plot into a different temporal or spatial setting. For example, the plot of Disneys "Beauty and the Beast" was transported into the USA of the 21st century for the film "Beastly" that was released in 2011.

\section{Quotation: ${ }^{78}$}

A quotation describes the using of fictional elements from a certain storyworld within a different and completely unrelated storyworld - for example, the use of lightsabers from Star Wars within the storyworld of Harry Potter.

73 Saint-Gelais, Richard: “Transfictionality”, In: Routledge Encyclopedia of Narrative Theory (London: Routledge, 2005) page 612 et seq.

74 Ryan, Marie-Laure: “Transmedia narratology and transmedia storytelling”, In: Artnodes no. 18 (Barcelona: Universitat Oberta de Catalunya, 2016) page 1-10.

75 Doležel, Lubomír: Heterocosmica: Fiction and Possible Worlds (Baltimore: John Hopkins University Press , 1998) page 206 et seq.

76 Ryan, Marie-Laure: “Transmediales Erzählen im Zeitalter der Medienkonvergenz”, In: “Medien. Erzählen. Gesellschaft” (De Gruyter: Berlin, 2013) page 91 et seq.

77 Doležel use the term "displacement" and Ryan the term "modification". I prefer the term "modification" because "displancement" point to a context that is already covered by "transposition”. "Quotation" is a operation defined by Ryan only, and was not mentioned by Doležel. 
Transfictional operations that link fictional storyworlds through various document relate to the original storyworld in different ways: ${ }^{79}$

- Overlapping with the original storyworld by modification and transposition.

- Inclusive the original storyworld by the extension through various creators.

- Being an original part of the same storyworld by the extension through the same creator.

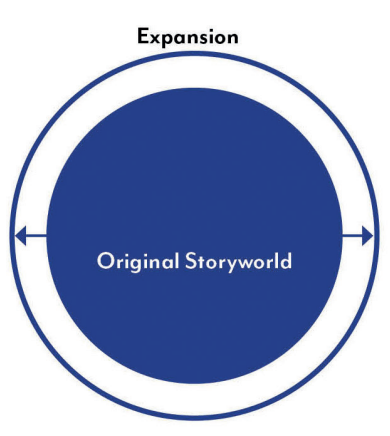

Expansion by the Original Creator

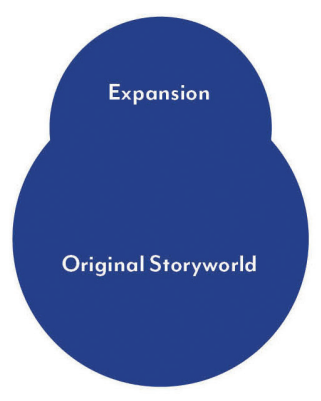

Expansion by Other Creators

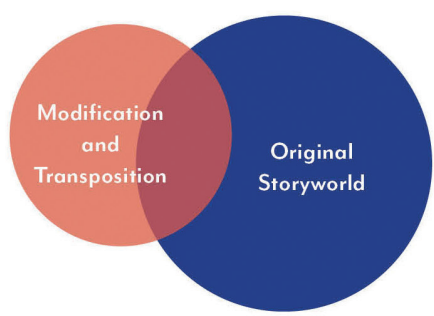

Modification and Transposition

Figure 3 Transfictional operations (Source: Personal collection leaned on Marie-Laure Ryan).

These relations and operations enable the opportunity to explore the fundamental processes for transmedia storytelling and what is necessary, that the audience comes to the term that multiple documents contain the same fictional storyworld.

\subsection{Transmedia story systems}

The following subchapter discusses what relations and strategies are most common and useful for a transmedia storytelling system concerning fictional content.

Extensions are the most common relations between media documents that are inside of a transmedia storytelling system. Modifications and transpositions are much less common than extensions because these relations threaten the integrity andconsistency of the original storyworld ${ }^{80}$. The communication scientist Carlos Alberto Scolari defined four strategies to expand a storyworld: ${ }^{81}$

79 Ryan, Marie-Laure: “Transmediales Erzählen im Zeitalter der Medienkonvergenz”, In: “Medien. Erzählen. Gesellschaft” (De Gruyter: Berlin, 2013) page 95.

80 Ryan, Marie-Laure: “Transmediales Erzählen im Zeitalter der Medienkonvergenz”, In: “Medien. Erzählen. Gesellschaft” (De Gruyter: Berlin, 2013) page 97.

81 Scolari, Carlos Alberto: Transmedia Storytelling: Implicit Consumers, Narrative Worlds, and Branding in Contemporary Media Production, In: International Journal of Communication 3 (Barcelona: University of Catalunya, 2009) page 598. 
The creation of interstitial microstories: These stories enrich the period between the seasons of a series. Prequels and sequels could also be classified into this kind of strategy because they expand the period of the original narrative. ${ }^{82}$

The creation of parallel stories: These stories proceed in the same time-line as the original story, for example, by unfolding the fate of supporting characters or telling the story from the antagonist. Parallel stories may evolve and transform into a spin-off. ${ }^{83,} 84$

The creation of peripheral stories: Peripheral stories are satellite-stories that have a strong or less strong relation to the original story, such as publications that contain specific folklore (see Chapter 3.3. - Storyworlds) from the original storyworld. These stories could also be transformed into a spin-off.

The creation of user-generated content or the use of fan culture: These stories are known as fanfictions and could be hosted on blogs or wikis. However, these stories could belong to modification and transposition, too. For some scientists, there is a debate on whether this strategy belongs to a transmedia storytelling franchise because fanfictions are usually outside the copyright owner's control. ${ }^{85}$

These strategies are used to expand a single storyworld into a vast transmedia storytelling system. In the previous chapter, it was declared that every recipient has his/her unique mental model of the storyworld in his/her mind. Therefore we cannot talk about a uniform storyworld that is the same for everyone.

However, in practical use, this is precisely how the recipients act. Most recipients go along with the approach that they mean the same uniform world when talking about Harry Potter or The Lord of the Rings. Maybe every recipient has his/her very own mental model of a storyworld within his/her mind, but the storyworld is treated uniformly in public.

The most important factor that a storyworld is perceived consistent by multiple recipients is the setting of the storyworld. Static components should be retained to build the storyworlds unity and autonomy, valid for multiple media-documents. ${ }^{86}$ In contrast to the static components that retain the storyworld's unity, the dynamic components enrich the narrative's plot.

82 See fn. 80.

83 A spin-offs is a TV-series or film that has arisen out of another TV-series or film that is already successful.

84 See fn. 80.

85 Jenkins, Henry: Convergence culture - Where old and new media collide (New York: New York University Press, 2006) page 175 et seq.

86 Ryan, Marie-Laure: “Transmediales Erzählen im Zeitalter der Medienkonvergenz”, In: “Medien. Erzählen. Gesellschaft” (De Gruyter: Berlin, 2013) page 97 et seq. 
Ryan defines three typical components for a transmedia storytelling system: ${ }^{87}$

1. A core of canonic media documents that illustrate the same storyworld. In the case of The Lord of the Rings, it is the original trilogy.

2. Additional transmedia and cross-media documents, such as adoptions, sequels, prequels, and spin-offs that usually expand the original storyworld, and got produced under the creator license by external companies.

3. Apocryphal documents that are made by fans and enable operations like modification, transposition, and quotation.

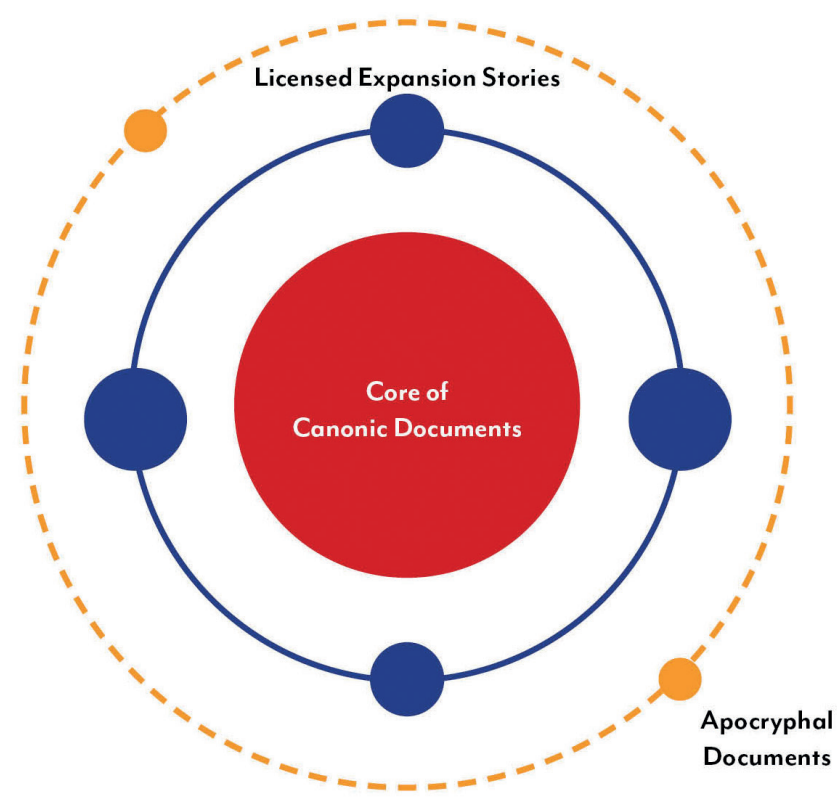

Figure 4 Documents of a transmedia storytelling system (Source: Personal collection leaned on Marie-Laure Ryan).

These components are standard for transmedia franchises that should be kept in mind by every media manager that supervises transmedia storytelling systems.

\subsection{Summary}

Transmedia storytelling relies on the concepts of transmediality and transfictionality and can appear in many forms, depending on various relations, sub-concepts, operations. A transmedia storytellings system could emerge independently from a cultural recognitions, or it could emerge as a planned strategy of a company.

87 See fn. 85 . 
The form of transmedia storytelling system that we know from successful commercial examples, such as The Lord of the Rings or Harry Potter, belongs to West Coast transmediality, is framed by a storyworld with various documents - one world relation, and is designed by several extensions. These extensions are transfictional operations and appear as interstitial microstories, parallel stories, peripheral stories, and user-generated content. However, there is a debate on whether user-generated content, such as fanfictions belongs to a transmedia storytelling system because they are outside of the copyright. Nevertheless, fanfictions and user-generated content are the basis of transmedia storytelling systems that gained cultural recognition independently. The storyworld contains several static and dynamic components and is a mental simulation of a world inside the recipient's mind. Although every recipient has his/her mental model of the storyworld, the storyworld is treated uniformly in public.

Based on the transfictional operations and the copyright and licensing areas, there are three essential components of a transmedia storytelling system - first, a core of canonic media documents that illustrate the same storyworld. Second, additional transmedia documents that expand the original storyworld under the creator's license. Third and last, apocryphal documents that are made by fans. 



\section{Examination of the Fantasy Genre}

This master thesis sets its focus on narratives and media content which belong to the Fantasy genre. Therefore, this chapter is about to create an appreciation for Fantasy. In the next chapter (chapter five - methods and acquisition), I am going to explain why I have explicitly chosen Fantasy content to examine transmedia storytelling for the publishing industry.

This chapter explains how to define Fantasy as a genre, what are traits of this genre, how to distinguish Fantasy from myths, science fiction, and speculative fiction, and how Fantasy can affect the media recipients. As well as examining transmedia storytelling, the study of Fantasy is not part of publishing technology and media engineering. It refers to the study of literature and narratology. Nevertheless, it is crucial to understand the type of content that is going to be published to deduce the right strategy and technology to aim for the highest possible economic success.

\subsection{Definition of Fantasy}

Fantasy got established as a separate genre with commercial significance in 1973 by literature reviews. ${ }^{88}$ In a strict sense, it already established at the end of the $19^{\text {th }}$ century as a genre without commercial significance. William Morris published the books "The Wood Beyond The World" and "The Well at the World's End" in 1894 and 1896, which could be classified completely as Fantasy. ${ }^{89}$ So William Morris is considered as the "father of Fantasy" 90 . In a wider sense, Fantasy as a literature form could hand back until the ancient times - for example, the "Epic of Gilgamesh" that hands back to 2100 B.C. But this sense is disputed because Fantasy should not put on the same level as myths, fables, or speculative fiction. ${ }^{91}$ This factor shows that the term and genre of Fantasy need a clear definition. There exist many attempts of a definition of Fantasy. The literature critic John Clute offers the following definition approach that Fantasy is a self-contained narrative with an impossible story that takes place in our world or a possible story that takes place in an impossible world..$^{92}$ This definition is very vague and extensive.

The scientist Dr. Frank Weinreich defines Fantasy by its traits in 2007, as he examines the content that is certainly classified as Fantasy beforehand. The definition approach "defining Fantasy by its traits" is also made by Fantasy author and editor

88 Pesch, Helmut: Fantasy - Theorie und Geschichte einer literarischen Gattung (Passau: Erster Deutscher Fantasy Club e.V., 2001) page 16 et seq.

89 Weinreich, Frank: Fantasy - Einführung (Essen: Oldib Verlag Oliver Bidlo, 2007) page 79 et seq.

90 Carter, Lin: Imaginary Worlds - The art of Fantasy (New York: Ballantine Books, 1973) page 20.

91 Weinreich, Frank: Fantasy - Einführung (Essen: Oldib Verlag Oliver Bidlo, 2007) page 63 et seq.

92 Clute, John/Grant, John: The Encyclopedia of Fantasy (New York: St. Martins Press, 1997). 
Helmut Pesch in 2001. In 2009 the communicology scientist Dr. Bastian Jenderek defined Fantasy by its traits based on the spadework from Pesch and Weinreich. Especially the approaches of Weinreich and Jenderek contain nearly the same aspects; only the systematization of these aspects differs.

In this master thesis, I will make a summarization of the definition approaches of Pesch, Weinreich, and Jendereck with annotations of new aspects that appeared in the past years by the envolving media systems. The definition of traits that is given by these experts appears very conclusive to me because it ascertains crucial elements that are part of every Fantasy medium story design. These traits also act as a tool to distinguish Fantasy from literary forms that are very similar to Fantasy but still do not feel the same - for example, religion, horror, and science fiction. In the next chapter, I will present a data ascertainment which was processed by three famous Fantasy storyworld examples. These examples also contain all the traits that I will introduce now. So it is advantageous to stick to the presented definitions approach.

In general, there are three essential traits of Fantasy:

- The secondary world

- The metaphysical power

- The heroic element

These traits define the Fantasy genre and apply to nearly all examples in specific designs. In the following paragraphs, I will describe the traits in detail.

\subsubsection{The secondary world}

The secondary world, also called otherworld or imaginary world, is a world that is completely fictional or fictional in certain parts of the world. In this master thesis, I commit to the term "secondary world" for the Fantasy storyworld and "primary world" for the real existing world.

The secondary world could be completely different from the primary world or very similar. But the similarity of the primary and secondary world is not the crucial aspect to distinguish these from each other.

For example, the secondary world of The Lord of the Rings "Middle-Earth" is completely different from the primary world in its geography and nature. So it is clear that they are not the same, but Middle-Earth could be a real existing world nevertheless. It could be technically possible to reach middle earth someday. So this would be more fitting to science fiction than Fantasy.

The crucial aspect is the otherness in physical aspects like space, time and causality. When things inside the world happen that are not part of the empirical field and cause an otherness in only one of the physical aspects, the world reveals oneself as a secondary world..$^{93}$ The probably most common

93 Jenderek, Bastian: Fantasy und Realität - Eine empirische Untersuchung zur Wirkung des Genre Fantasy (Hamburg: tredition $\mathrm{GmbH}, 2009$ ) page 7 et seq. 
thing, which disclosed the secondary world, is the trait of metaphysical power or magic.

For example, the world of Harry Potter is seemingly the same as the primary world. But it is the functioning of magic that causes things that are impossible in our primary empirical world, and so this aspect determines the world of Harry Potter as the secondary one. Magic or a certain metaphysical power is also the aspect that sets middle earth and The Lord of the Rings to Fantasy.

Besides the otherness in physical aspects, the secondary world should have an inner coherence and seriousness. The secondary world follows norms that provide an inner coherence. Although the secondary world differs from the primary one, the secondary world scoops from the primary world. They are linked, at least from the aspect that the creator or author of the secondary world lives inside the primary world.${ }^{94} \mathrm{Dr}$. Jenderek explains that it is difficult to build consistency within the secondary world because the recipient handles information with perceptual strategies based on the experience that the recipient gained from the primary world. So the recipient compares information from a secondary world with pieces of information from the primary world, to avoid inconsistency. ${ }^{95}$ J.R.R. Tolkien states that in practice, it is harder to create inner consistency of reality, the less the description and imagination of things inside the secondary world resemble the primary world. ${ }^{96}$ So this state confirms the theory that the more the secondary world resembles the primary one, the more inner consistency and coherence come along.

The seriousness of the secondary world comes along with claiming supernatural happenings as real facts inside this world. The functioning of magic is a common fact inside the world of Harry Potter. In contrast, the protagonist in Lewis Carrolls "Alice" knows that all supernatural things are supernatural and not common or even possible to the real world. ${ }^{97}$

The last and probably most trivial trait of the secondary world is that it should contain the metaphysical power, heroes, and creatures. ${ }^{98}$

In conclusion, the secondary world needs to:

- reveal itself as the secondary world in distinction from the primary world,

- have an inner coherence and consistency,

- take itself seriously (keeps a secondary reality)

- and contains all the metaphysical power and beings inside

In the next chapter, I will take a closer look at the trait of metaphysical power.

94 Weinreich, Frank: Fantasy - Einführung (Essen: Oldib Verlag Oliver Bidlo, 2007) page 24 et seq.

95 Jenderek, Bastian: Fantasy und Realität - Eine empirische Untersuchung zur Wirkung des Genre Fantasy (Hamburg: tredition $\mathrm{GmbH}, 2009)$ page 8 et seq.

96 Tolkien, John Ronald Reuel: On Fairy-Stories, In: Gute Drachen sind rar. (Stuttgart: Klett-Cota, 1984) page 103.

97 Clute, John/Grant, John: The Encyclopedia of Fantasy (New York: St. Martins Press, 1997) pag 874.

98 Jenderek, Bastian: Fantasy und Realität - Eine empirische Untersuchung zur Wirkung des Genre Fantasy (Hamburg: tredition $\mathrm{GmbH}, 2009$ ) page 5 et seq. 


\subsubsection{Metaphysical power}

The metaphysical power is the main trait that makes it possible to distinguish the secondary world from the primary world. It is the explanation of any phenomenon that can not be explained by the laws of physics. Therefore, metaphysical power is an aspect that breaks with reality. ${ }^{99}$ It delivers causalities for events that are impossible in the primary word.

The metaphysical power expresses itself in different versions depending on the Fantasy narrative - for example, it is magic in Harry Potter and the force in Star Wars.

It is crucial for the excitement of the story and the consistency of the secondary world that the metaphysical power or magic follows self-imposed restrictions. ${ }^{100}$ For example, magic needs mental exertion and works only under certain circumstances. Such restrictions avoid overreaching within the story and support the causality principle that we know from the primary world. ${ }^{101}$

The metaphysical power generates consequences that affect the nature of the secondary world. Such consequences implement themselves in the form of magical creatures and objects, like elves, orcs, dragons, or magic wands. Furthermore, the magic affects the characters of the story. ${ }^{102}$

The academic Dörthe Schilken postulates two terms that describe and embrace the consequences of metaphysical power - Fantasy Inventory and Fantasy Structure. ${ }^{103}$ Fantasy Inventory includes magical objects, magical creatures, technology, morals, and the society of the secondary world. ${ }^{104}$ Fantasy Structure includes general narratological characteristics of the genre. ${ }^{105}$

Besides, Jenderek divided magical objects into two different types, based on Schilken's theory: ${ }^{106}$

First, objects that can only be used by a certain person or objects that pursue a certain purpose. Jenderek called these objects "specific symbols of power", and they are an indication for the determinism of the story, an element that I will describe in the next chapter. For example, The One Ring of The Lord of the Rings can only be used by The One Ring to pursue the purpose of subjugating all other beings in middle earth.

99 Weinreich, Frank: Fantasy - Einführung (Essen: Oldib Verlag Oliver Bidlo, 2007) page 27 et seq.

100 Clute, John/Grant, John: The Encyclopedia of Fantasy (New York: St. Martins Press, 1997) page 615 et seq.

101 Eddings, David; Eddings, Leigh: Der Riva-Kodex. Bergisch-Gladbach: Bastei Lübbe, 2000).

102 Jenderek, Bastian: Fantasy und Realität - Eine empirische Untersuchung zur Wirkung des Genre Fantasy (Hamburg: tredition $\mathrm{GmbH}, 2009$ ) page 12 et seq.

103 Schilken, Dörthe: Die teleologische Reise von der christlichen Pilgerallegorie zu den Gegenwelten der Fantasy-Literatur. (Würzburg: Könighausen und Neumann, 2002).

104 Schilken, Dörthe: Die teleologische Reise von der christlichen Pilgerallegorie zu den Gegenwelten der Fantasy-Literatur. (Würzburg: Könighausen und Neumann, 2002) page 245 et seq.

105 Schilken, Dörthe: Die teleologische Reise von der christlichen Pilgerallegorie zu den Gegenwelten der Fantasy-Literatur. (Würzburg: Könighausen und Neumann, 2002) page 245.

106 Jenderek, Bastian: Fantasy und Realität - Eine empirische Untersuchung zur Wirkung des Genre Fantasy (Hamburg: tredition $\mathrm{GmbH}, 2009$ ) page 13 et seq. 
Second, objects that can be used by a random person with no specific purpose. Jenderek called these objects "general symbols of power", and they are an indication for the existence and functioning of metaphysical power.

\subsubsection{The heroic element}

The last main trait to define Fantasy is the heroic element and consists of two components.

The first component is the existence of heroic characters in the secondary world. The heroic characters are the agents of the Fantasy story. The element includes protagonists, antagonists, failing, and inconspicuous characters. They are mostly involved in adventurous situations. ${ }^{107}$

The second component is the quest of the heroic characters. The heroic character confronts an enormous mission or hindrance which the character has to fulfill or overcome. In this case, the heroic character often makes use of his/her supernatural power or supernatural tool or a combination of both. ${ }^{108}$ The quest is the basic theme of the narrative, enables orientation to well-known structures for the author, and generates a certain expectation for the recipient. ${ }^{109}$

For example, Harry Potter has the heroic quest to defeat the almighty black magician Lord Voldemort. Both Harry Potter and Lord Voldemort are heroic characters of the story. Harry uses his magical nature and a magic wand to defeat Lord Voldemort. So he made use of his magical power and also of a tool that supports him in his quest.

Furthermore, Jenderek defined a further component of the heroic element that is typical, but not necessary for the Fantasy genre - the "foregone fate." The heroic character must pursue the foregone, which ensures that the heroic character can not vanish out of the story until the agent fulfills his/her foregone. Within the story, the foregone is often recognizable by the appearance of an oracle or prophecy. In this case, free choices of the heroic characters or coincidence are just an illusion. ${ }^{110}$

For example, there is a prophecy that foretells that someone (Harry Potter) will appear "with the power to vanquish"111 Lord Voldemort and Lord Voldemort "[...] will mark him as his equal [...], and either must die at the hand of the other for neither can live while the other survives[... "112. This prophecy is an indication of the foregone of Harry Potter.

This component seems to be trivial because, of course, the creator of the story defined the whole plot. The protagonist is fictional, as well as the storyworld, and no

107 Weinreich, Frank: Fantasy - Einführung (Essen: Oldib Verlag Oliver Bidlo, 2007) page 23.

108 Weinreich, Frank: Fantasy - Einführung (Essen: Oldib Verlag Oliver Bidlo, 2007) page 23 et seq.

109 Jenderek, Bastian: Fantasy und Realität - Eine empirische Untersuchung zur Wirkung des Genre Fantasy (Hamburg: tredition $\mathrm{GmbH}$, 2009) page 15 et seq.

110 Jenderek, Bastian: Fantasy und Realität - Eine empirische Untersuchung zur Wirkung des Genre Fantasy (Hamburg: tredition GmbH, 2009) page $15-21$.

111 Rowling; Joanne K.: Harry Potter and the Order of the Phoenix, Chapter 37 - The Lost Prophecy (London: Bloomsbury, 2003).

112 See fn. 111. 
one inside this world is real existing and, therefore, able to make free and independent decisions. ${ }^{113}$

In my opinion, the foregone that exposes itself in the form of a prophecy or oracle with the storyworld is a typical trait of the Fantasy story. Besides, the unawareness of the hero in regards to his/her foregone is a reassurance for the seriousness of the secondary world and its secondary reality. Lastly, new media systems, like computer games or ebooks with a decision-based story-line, could involve the recipient to submit to or change the foregone. Such participation could be a design strategy and even a competitive advantage.

These genre-typical components of the heroic element belong to the Fantasy Structure, the term that Schilkens has defined besides the Fantasy Inventory.

\subsubsection{Demarcating Fantasy from related terms and genres}

When people talk about Fantasy, there are a lot of various related terms and genres besides Fantasy that could appear. Such as speculative fiction, myths, and fables. I want to ensure a clearer definition of Fantasy by demarcating it from related terms and genres. In my opinion, such clarification could help detecting specifications and potential publishing opportunities, too.

\section{Speculative fiction}

Speculative fiction is a collective term for literary works with content that cross the border of the understandable empirical reality. ${ }^{114}$ So, speculative fiction involves Fantasy, myths, sagas, fairytales, fables, horror, and much more literary genres.

\section{Myths}

Myths are oral traditions of gods, heroes, and supernatural creatures. ${ }^{115}$ In contrast to Fantasy, myths claim extern veracity and validity or, at least, they claimed it in time of their emergence. Until medieval times, myths had the status of a non-fictional text because they were the figurative explanation of the world. ${ }^{116}$ The Fantasy genre claims inner veracity concerning the secondary reality concept.

Nevertheless, Fantasy scoops from myths by using figures, metaphors, and symbols that appear in myths, such as dragons, dwarfs, elves, and so on. ${ }^{117}$ This factor does not apply to Fantasy only. Further various sub literary forms come under speculative fiction scoops from myths, too.

113 Jenderek, Bastian: Fantasy und Realität - Eine empirische Untersuchung zur Wirkung des Genre Fantasy (Hamburg: tredition $\mathrm{GmbH}, 2009$ ) page 16 et seq.

114 La Blanc, Thomas: Was ist eigentlich Fantasy? In: Tolkien Times (Stuttgart: Klett-Cotta, 2003) page 3.

115 Brockhaus Enzyklopädie Online: Mythos. NE GmbH | Brockhaus, 2019, https://brockhaus.de/ecs/ permalink/A4C08F6CAF6B5CEBE9C3B665379EB21A.pdf [last accessed on 2019.09.27]

116 Rühling, Lutz: Vorraussetzungen und Grundlagen der Literaturwissenschaft, In: Grundzüge der Literatur Wissenschaft (Munich: DTV, 1997) page 29.

117 Waggoner,Diana: The Hills of Faraway (New York: Atheneum, 1978) page 21. 
Furthermore, myths provide a meaningful function to Fantasy. The events of a Fantasy story, as well as the whole secondary world, reflect real events from the primary world. ${ }^{118}$ Fantasy does not explain the world as myths did, but it comments on the primary world. ${ }^{119}$

\section{Religious texts, sagas, fairytales, and horror}

All these literary forms use supernatural elements. Religious texts use supernatural elements like angels, devils, or monsters to symbolize and explain their ideology and dogma. But they address the primary world and do not create a secondary world. ${ }^{120}$ It is nearly the same with horror. In horror, supernatural creatures, like vampires, demons, and werewolves, break into the primary world to provide an entertainment experience. ${ }^{121}$

Sagas are oral traditions that make use of supernatural things, such as giants, dragons, witches, and much more. But sagas have a strong reality- aspiration and often address real places, times and persons of the primary world, and do not create a secondary world as well. ${ }^{122}$

Fairytales have a wide more fictional composition than sagas. In the time of the Grimm Brothers, fairytales got a definition as an independent literary form initially, marked-off from the saga. Fairytales are oral or written narratives, mostly based on folktales. They do not necessarily name a certain place or time where the story happens. ${ }^{123}$ Fairytales feature the same structure as Fantasy, but most of them are based on folktales. Therefore, they address the primary world and do not create a secondary world or show the necessary pitch of seriousness and inner coherence that Fantasy requires. Nevertheless, it is possible to view Fantasy as the advancement of fairytales. ${ }^{124}$

Many bestseller lists and statistics mention Fantasy in the same breath as science fiction. But in the proper meaning, science fiction is not even part of the speculative fiction. The content of science fiction takes up narratives about future developments and events that break the current state of technical and scientific borders. ${ }^{125}$ In this case, science fiction could build fantastic conjectures, but it appeals that it could be technically possible in the future, while it does not appeal to a metaphysical power, like magic or the force. ${ }^{126}$

118 Weinreich, Frank: Fantasy - Einführung (Essen: Oldib Verlag Oliver Bidlo, 2007) page 32 et seq.

119 Waggoner,Diana: The Hills of Faraway (New York: Atheneum, 1978) page 6 et seq.

120 Weinreich, Frank: Fantasy - Einführung (Essen: Oldib Verlag Oliver Bidlo, 2007) page 60 et seq.

121 Weinreich, Frank: Fantasy - Einführung (Essen: Oldib Verlag Oliver Bidlo, 2007) page 29 et seq.

122 Brockhaus Enzyklopädie Online: Sage. NE GmbH | Brockhaus, 2019, https://brockhaus.de/ecs/ permalink/DAD1F292751EEC94F609483A4DA28EA7.pdf [last accessed on 2019.09.30]

123 Brockhaus Enzyklopädie Online: Märchen. NE GmbH | Brockhaus, 2019, https://brockhaus.de/ ecs/permalink/453B77062986C05BE545A4FD9D83FADF.pdf [last accessed on 2019.09.30]

124 Jenderek, Bastian: Fantasy und Realität - Eine empirische Untersuchung zur Wirkung des Genre Fantasy (Hamburg: tredition $\mathrm{GmbH}, 2009$ ) page 3.

125 Brockhaus Enzyklopädie Online: Science Fiction. NE GmbH | Brockhaus, 2019, https://brockhaus. de/ecs/permalink/825FDD55C2A2E962E6AA53FD28578471.pdf [last accessed on 2019.10.07]

126 Weinreich, Frank: Fantasy - Einführung (Essen: Oldib Verlag Oliver Bidlo, 2007) page 30/67 et seq. 


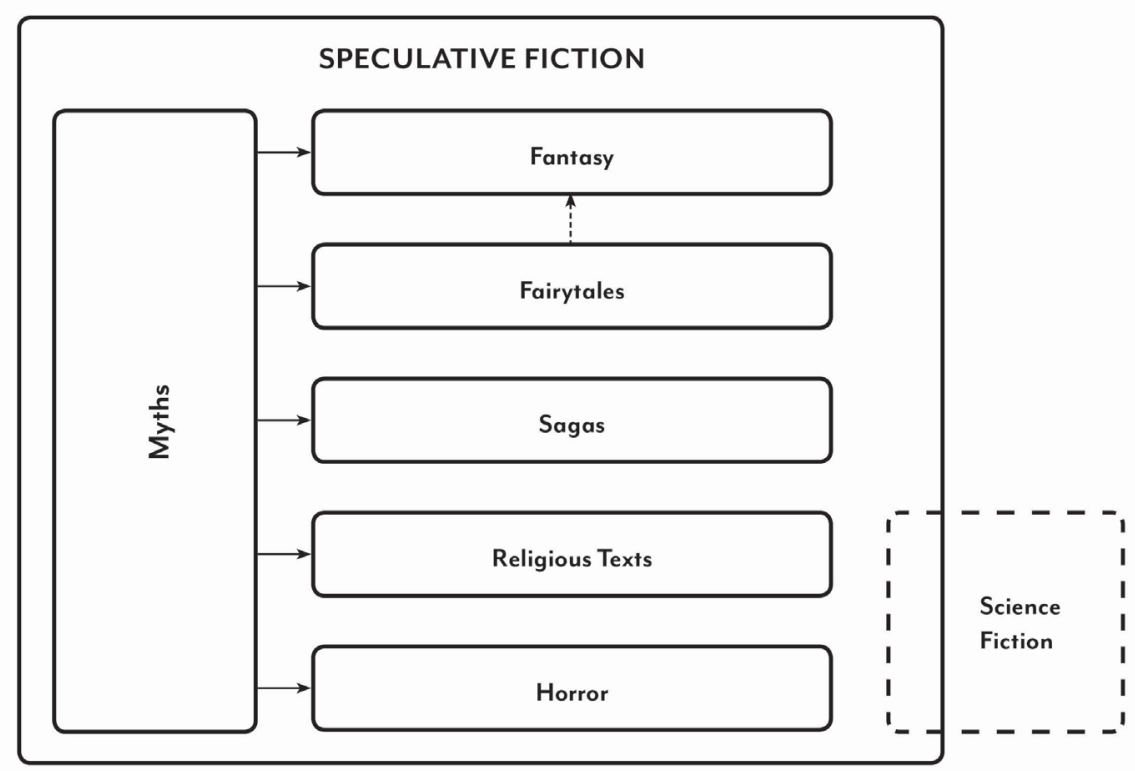

Figure 5 Classifiction of speculative fiction (Source: Personal collection).

\subsubsection{Summary}

In conclusion, it is hard to find a normative definition of the Fantasy genre. It seems more appropriate to make a descriptive definition since many cross-border and diverse examples of this genre are taken into account. The Fantasy genre is part of speculative fiction, carries on traits of the fairytale-literature genre, and consists out of three main traits: the secondary world, the metaphysical power, and the heroic element.

The secondary world is self-contained, maintains a certain inner coherence and seriousness, and isolates itself clearly from the primary world. The metaphysical power is a fact inside the secondary world, supports the distinction from the primary world, and causes the Fantasy inventory. The Fantasy inventory consists of magical objects and creatures that have a link to the Fantasy structure. The appearance of heroes that have special abilities, handicaps, or quests is part of the heroic element that causes the Fantasy structure.

Two further crucial aspects that distinguish Fantasy from other genres are that all supernatural elements are common facts inside the secondary world, and Fantasy does not address the primary world. 


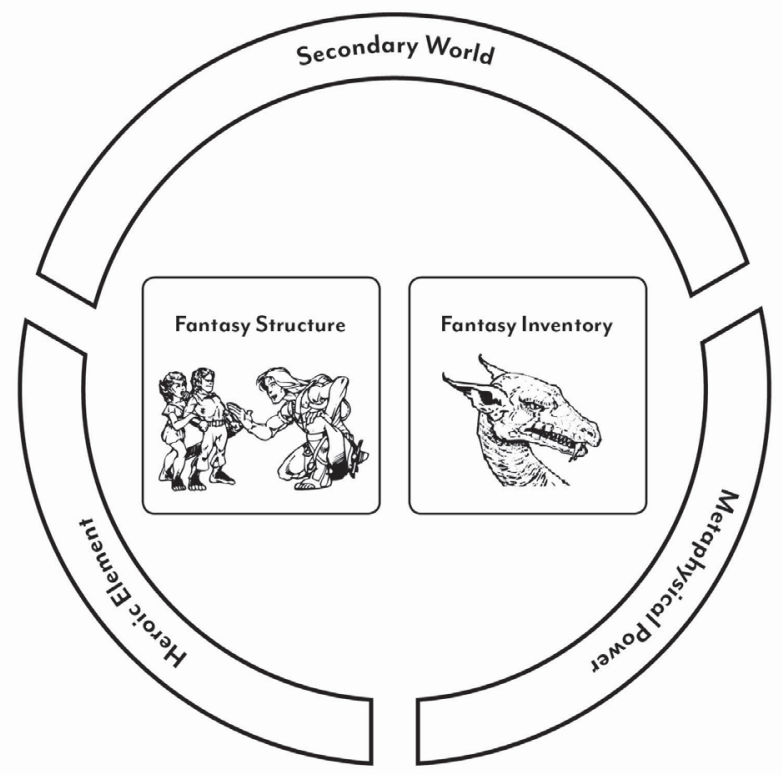

Figure 6 Fantasy components (Source: Personal collection).

\subsection{The German Fantasy market}

This subchapter examines the German market of Fantasy media. An essential part of this master thesis is the survey (see chapter 5) about the consumption of Fantasy media across different media types. This survey was executed in Germany, and therefore it is advisable to set the focus on the German Fantasy market.

\subsubsection{Fantasy in TV, films, and series}

The institute of public opinion poll Allensbach published two statistics that make a statement about the Fantasy genre in the German TV landscape. First, in 2019, 15.8\% of all interviewees declared the Fantasy genre as their favored TV format. ${ }^{127}$ This is a growth of $0.6 \%$ in comparison to 2017 , where it only was $15.2 \%$ of all interviewees. ${ }^{128}$ Second, 13.46 million Germans stated that they watch Fantasy and science fiction on TV willingly, and 11.14 million Germans watch Fantasy and science fiction on TV especially. ${ }^{129}$ Unfortunately, in the first quoted statistics, there is no

127 IfD Allensbach: Beliebteste Fernsehformate in Deutschland in den Jahren 2017 bis 2019. Statista, Statista GmbH, 2019. https://de.statista.com/statistik/daten/studie/171208/umfrage/beliebtestefernsehformate/ [last accessed on 2019.10.14].

128 See fn. 127.

129 IfD Allensbach: Bevölkerung in Deutschland nach Beliebtheit von Science-Fiction- und Fantasy-Filmen 
number of total questioned interviewees given, so it is not possible to make a statement about the validity of the reference value.

Statista, a German web portal for statistics, published a statistic about the TV consumption behavior in Germany, too. Their results reveal that $42 \%$ from a total of 923 interviewees that are between 16 and 64 years old stated that they generally watch Fantasy content on TV. ${ }^{130}$ This is the fifth-largest share of the total results. The institute of public opinion poll Allensbach survey people from 14 years old and could have a more significant reference value of interviewees.

A statistic from the Norstat, a German market research institute, go adrift from the only TV and reveal results of the most favored series genres with relation to video-on-demand platforms, streaming platforms, and TV. In this statistic, 12\% from a total of 1416 interviewees stated Fantasy as their most favored series genre, ${ }^{131}$ and this represents the third-largest share of all given genres.

An information graphic from Statista supports the results of the Norstat statistic that the Fantasy genre proves popular on series. This information graphic shows the amount of drama, comedy, and Fantasy/ science fiction genres in the upcoming series list of Netflix, HBO, Amazon Prime Video, Hulu, and Apple TV, effective $16^{\text {th }}$ October 2018. The information graphic reveals that $20 \%$ of a total of 257 upcoming Netflix series are from Fantasy or science fiction genres. In the case of Amazon Prime Video, it is $25 \%$ of 97 upcoming series, $17 \%$ of 64 upcoming series for $\mathrm{HBO}, 9 \%$ of 53 upcoming series in the case of Hulu, and the last $17 \%$ of 23 upcoming series for Apple TV. For Netflix and Amazon Prime Video, Fantasy and science fiction represent the second-biggest share, and for the rest, it is the third-largest share. ${ }^{132}$

A further indicator of how Fantasy is established on the German and even global media market is the success of film series. The web portal Box Office Mojo published a list of film series ranked by box-office revenues until July 2019. Now take a close look at only the top three of this list: ${ }^{133}$

im Fernsehen von 2015 bis 2019 (Personen in Millionen). Statista, Statista GmbH, 2019. https://de. statista.com/statistik/daten/studie/171204/umfrage/interesse-an-science-fiction-und-fantasyfilmen/ [last accessed on 2019.10.14].

130 Statista: Welche Art Filme und Shows konsumieren Sie generell im Fernsehen (Übertragung/Kabel) Satellit)?. Statista, Statista GmbH. https://de.statista.com/prognosen/999813/umfrage-indeutschland-zu-beliebten-fernseh-genres [last accessed on 2019.10.14].

131 Norstat: Welches Serien-Genre schaust Du am liebsten?. Statista, Statista GmbH, 2017. https:// de.statista.com/statistik/daten/studie/788528/umfrage/beliebtheit-von-serien-genres-in-deutschland/ [last accessed on 2019.10.14].

132 Brandt, M.: Netflix setzt auf Comedy, Amazon auf Drama. Statista, Statista GmbH, 2018. https:// de.statista.com/infografik/15794/anzahl-genres-kommender-serien-von-video-streaminganbietern/ [last accessed on 2019.10.14].

133 Box Office Mojo: Ranking der nach Einspielergebnis erfolgreichsten Filmreihen und -franchises weltweit bis Juli 2019 (in Milliarden US-Dollar), Chart 16th June 2019. Statista, 2019. https://de. statista.com/statistik/daten/studie/932924/umfrage/erfolgreichste-filmreihen-und-franchisesnach-einspielergebnis/ [last accessed on 2019.10.14]. 
- The Marvel Universe with 22.29 billion USD,

- The Star Wars series with 9.49 billion USD,

- The magical world by J.K. Rowling with 9.19 billion USD.

The Star Wars series belongs to the Fantasy or science fiction genre, relative to the respective notion. The magical world by J.K. Rowling belongs clearly to the Fantasy genre. The Marvel Universe is a film series based on the origin of the Marvel comics and tells about superhero adventures. Such superhero stories represent a sub-genre of Fantasy by matching nearly all traits of the Fantasy definition. For sure, there are also superhero stories that break the border of the Fantasy definition, but in the case of Marvel, the films match the defining traits of the Fantasy genre. Some superheroes have metaphysical power, the heroic element, and Fantasy structure is the most distinctive trait of superhero stories, and the secondary worlds reveal itself by the functioning of metaphysical power and the appearance of supernatural creatures, objects, and side planets. In conclusion, all these three series of bestsellers exhibit many Fantasy traits or belong to this genre completely. In total, 9 of 20 film series in this list exhibit Fantasy traits or belong to this genre entirely.

\subsubsection{Fantasy in books}

The Fantasy and science fiction genre represented $5.2 \%$ of the whole belletristic book trade revenue in 2018. In contrast to 2010, with $8.1 \%$ of the total belletristic book trade revenue, Fantasy and science fiction literature suffer a loss of $2.9 \% .{ }^{134}$ The total revenue of the German book trade amounts to 9134 million euros, ${ }^{135}$ with a share of $31.5 \%{ }^{136}$ for belletristic literature. Therefore, the belletristic revenue share amounts to approximately 2877 million euros, and consequently, the Fantasyscience fiction share amounts to approximately 147 million euros in 2018. A projection based on the book trade sales trend predicts the growth of up to 4420 million euros annual turnover until the year 2022. ${ }^{137}$ As a result, one could predict that the

134 Börsenverein des Deutschen Buchhandels: Entwicklung des Umsatzanteils der Editionsform Science-Fiction und Fantasy in der Warengruppe Belletristik im Buchhandel in Deutschland in den Jahren 2009 bis 2018. Statista, Statista GmbH, 2019. https://de.statista.com/statistik/daten/ studie/984310/umfrage/entwicklung-des-umsatzanteils-der-editionsform-science-fiction-undfantasy-im-deutschen-buchhandel/ [last accessed on 2019.10.14].

135 Börsenverein des Deutschen Buchhandels: Geschätzte Umsätze im deutschen Buchhandel in den Jahren 2007 bis 2018 (in Millionen Euro). Statista, Statista GmbH, 2019. https://de.statista.com/ statistik/daten/studie/195369/umfrage/umsaetze-im-deutschen-buchhandel-seit-2007/ [last accessed on 2019.10.21].

136 Börsenverein des Deutschen Buchhandels: Umsatzanteile der einzelnen Warengruppen im Buch handel in Deutschland in den Jahren 2017 und 2018. Statista, Statista GmbH, 2019. https://de. statista.com/statistik/daten/studie/71155/umfrage/umsatzanteile-im-buchhandel-im-jahr-2008nach-genre/ [last accessed on 2019.10.21].

137 PwC: Umsatz auf dem deutschen Buchmarkt in den Jahren 2005 bis 2017 und Prognose bis 2022 nach Segmenten (in Millionen Euro). Statista, Statista GmbH, 2018. https://de.statista.com/statistik/ daten/studie/164550/umfrage/prognostizierter-umsatz-auf-dem-buchmarkt-in-deutschland- 
annual turnover for Fantasy and science fiction could grow as well, conditional from the supply and demand of the next years.

A further statistic reveals that 43\% from a total of 1025 interviewees read Fantasy literature at regular intervals. ${ }^{138}$ This result could be an indicator that the popularity of Fantasy is not properly represented through the revenue share.

In conclusion, the annual revenue share of the Fantasy and science fiction genre has sunk in recent years, but it seems to be still relevant inside the reading habits of German readers.

\subsubsection{Fantasy in computer games}

For computer games, it is more elaborate to locate the Fantasy genre inside this media market, because computer games mostly classify themselves by their game mechanics, the main technical traits and structures. The genre of the content or narrative is a subsidiary for this media. Therefore, computer games are classified as a shooter, role game, jump 'n' run or beat'em up and not as thriller, Fantasy, or historical games. The reason for this issue could be that a computer game does not have to contain a narrative. For example, simulation or puzzle games often have a narrative that is not sufficient to get classified or even get recognized as a narrative. In these cases, the narrative is more like an explanation of deeds. In conclusion, not all computer cames have a sufficient narrative, but all computer games have a structural and technical schematic that seemingly builds the basis of standard classification.

Nevertheless, there is an adequate way to locate the Fantasy genre in the market of computer games. Germany is the third biggest market for computer games in the world besides the United States and China, with an annual revenue of 4430 million US-dollar. ${ }^{139}$ The service host for PC building and technical web blog WePC published the worldwide unit sales of the best selling PC and console games of all times, based on data provided by VGchartz, an intelligence, and research firm. The game's narratives of these best selling lists can be checked with the Fantasy traits to make a statement about how many of these bestselling games include Fantasy narratives.

In the case of bestselling PC games of all time, there are samples that contain narratives and secondary worlds that clearly belong to the Fantasy genre, such as Star Wars, the Warcraft-franchise, The Elderscrolls V: Skyrim and Diablo III. The Warcraft franchise developed by Blizzard Entertainment has multiple storyworlds, such as Azeroth and Draenor, that are geographically totally different from our primary world -

seit-2005/ [last accessed on 2019.10.21]

138 Statista: Welche Genres lesen Sie regelmäßig?. Statista, Statista GmbH, 2018. https://de.statista.com/ prognosen/803022/umfrage-in-deutschland-zu-beliebten-literatur-genres [last accessed on 2019.10.14].

139 WePC: 2019 Video Game Industry Statistics, Trends \& Data. 2019. https:/www.wepc.com/news/ video-game-statistics/ [last accessed on 2019.10.18]. 
magic is functioning, offers a vast Fantasy inventory, such es orcs, dragons, etc., and various heroes are on their way to fulfill quests to rescue their world from demise. ${ }^{140}$

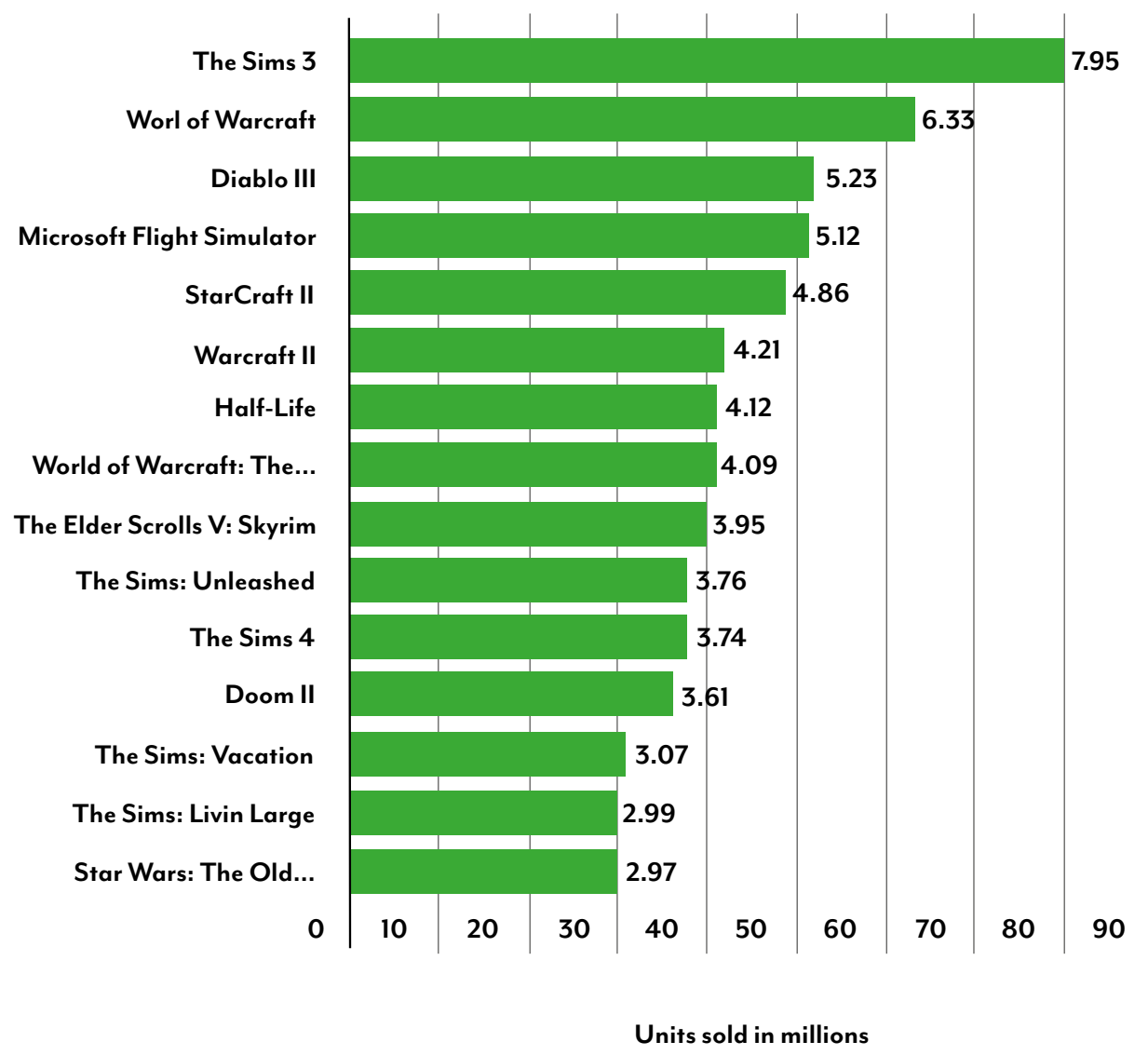

Figure 7 Worldwide Unit Sales of the Best Selling PC Games of All Times in Million Units (January 2018) (Source: VGChartz).

The storyline of the Elderscrolls franchise takes place in Tamriel, a secondary world that differs from the primary world in its geography and the functioning of magic. Tamriel contains a vast Fantasy inventory including many already mentioned creatures and objects, and especially in the case of The Elderscrolls V: Skyrim, the hero is on his or her quest to rescue the land of Skyrim from the danger of dragons. ${ }^{141}$ The Diablo franchise, also developed by Blizzard Entertainment, reveals similar properties as the previously

140 World of Warcraft.Blizzard: The story of warcraft. Blizzard Entertainment, Inc, 2019. https:// worldofwarcraft.com/de-de/story/timeline [last accessed on 2019.10.18].

141 Bethesda.Elderscrolls: THE ELDER SCROLLS V: SKYRIM. Bethesda Softworks LLC, a ZeniMax Media company, 2019. https://elderscrolls.bethesda.net/de/skyrim [last accessed on 2019.10.18]. 
mentioned samples and matches the Fantasy genre, too. ${ }^{142}$ Besides and also very essential, all these samples have an inner coherence and seriousness in their secondary world and do not address the primary world. In conclusion, six from a total of 15 games in the bestselling PC games list contain Fantasy narratives and secondary worlds.

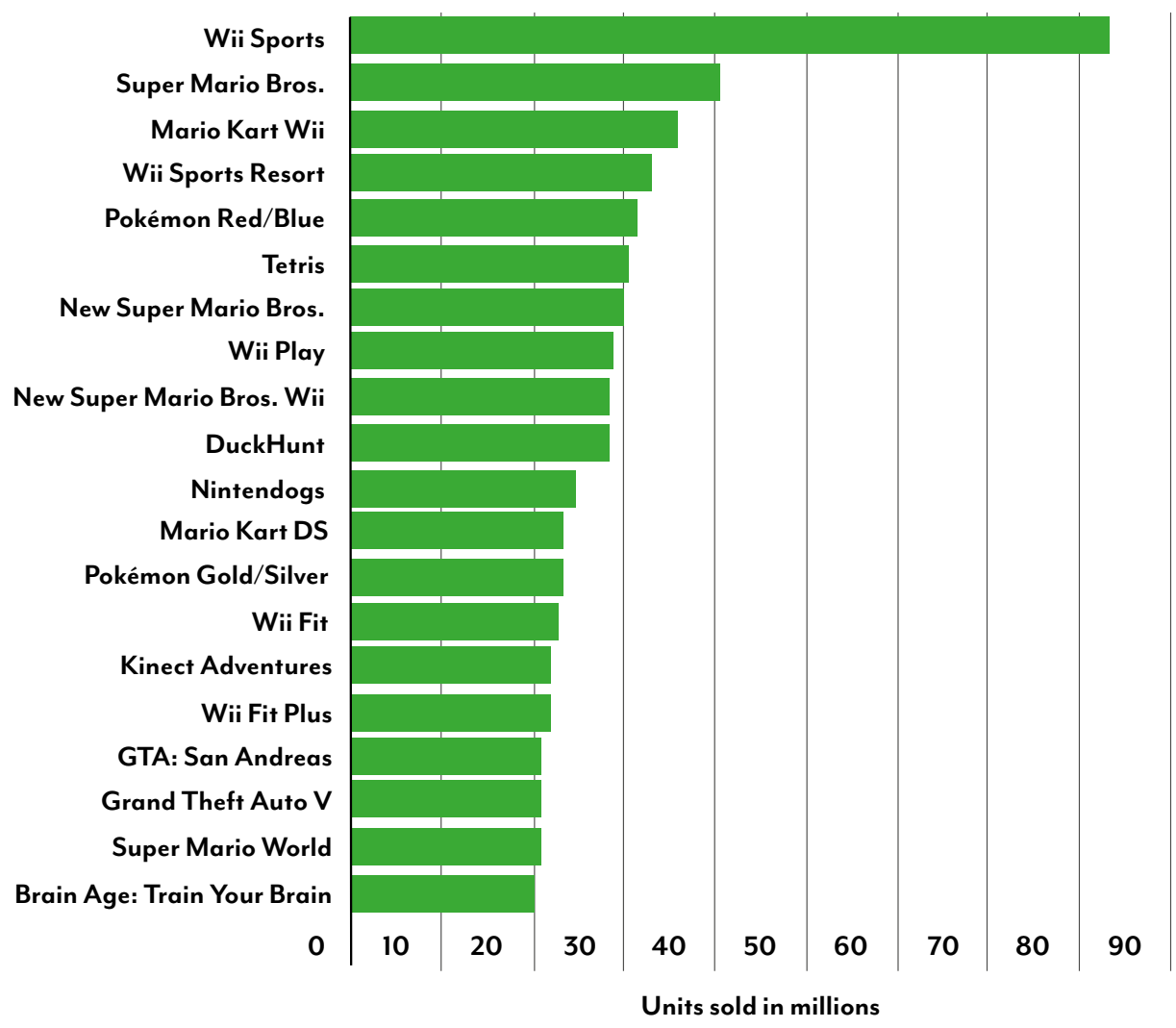

Figure 8 All-time Best-selling Console Games Worldwide of March 2018 (Source: VGChartz).

For console games, the only game franchise that could be related to the Fantasy genre could be the Pokémon franchise, because the game's world differs from the primary world in all relevant attributes, fictional creatures living in this world, and the player has the heroic quest to become a "Pokémon Master" and save the world from evil organizations, such as Team Rocket, Team Magma, Team Aqua and so on. ${ }^{143}$ The world of Pokémon also has an inner coherence and seriousness and do not

142 Diablo.Blizzard: The story of Diablio. Blizzard Entertainment, Inc, 2019. https://eu.diablo3.com/ de/game/the-story-of-diablo/?page=4 [last accessed on 2019.10.18].

143 Pokémon Wiki: The Pokémon Frachise. FANDOM Games Community, Fandom, Inc., 2019. https:// pokemon.fandom.com/wiki/Pok\%C3\%A9mon (franchise) [last accessed on 2019.10.18]. 
address the primary world. In comparison to Pokémon, the world of Super Mario Bros. does not have such an inner coherence, amount of information, and seriousness that would be enough to be classified as a serious Fantasy narrative. In conclusion, only two from a total of 21 games in the bestselling console games list contains a Fantasy narrative.

The examination of these lists also reveals that computer games that contain a Fantasy narrative belong to the classes of open-world, role-play, or tell-tale games because these classes of computer games can carry the whole storyline and specific secondary world properties.

In conclusion, many PC games that contain a Fantasy narrative achieved much success. Computer games are primarily classified by their technical and structural mechanics and traits. The content narrative is only a minor factor for its classification, but it can seemly help to pitch a computer game's success and establish game series and even franchises.

\subsubsection{In conclusion}

The Fantasy genre claims a significant amount of the diverse submarkets of media. It does not represent the very bestselling genre in TV, film, series, computer games, or book trade, but it is always among the top five of the bestselling genres, based on the revenue of the diverse markets in Germany. The creation of a secondary world and a vast storyline that includes a strong Fantasy structure and a big Fantasy inventory seems to support the establishment of media series and franchises. A piece of evidence that supports this thesis is that the most successful Fantasy examples of films, series, and computer games appear as a part of a series, such as Harry Potter, Star Wars, or World of Warcraft. Even in music can Fantasy narratives appear as part of concept albums, operas, or audio dramas, whereas they represent an uninvestigated scope of the media industry. 



\section{Implementation of a Survey: Consumption of the Same Fantasy Narrative in Different Media Types}

This chapter handles the structure, systematization, process, and results of a survey that should obtain information to answer and discuss the research questions. The survey appeals to the consumption of the same fantasy narrative in different media types, and the results shall provide information about the questions: Do people consume a fantasy narrative across different media? What media types and forms consume the target audience preferentially? Is the mothership of a transmedia franchise more often in a book or non-book form? Based on the consumption behavior, is it possible to infer statements of the narrative's complexion from it? ... and what are the motives of consuming a fantasy narrative across different media types?

The answers to all these questions are crucial for stating whether transmedia storytelling has an empiric practical impact on the publishing industry and what can be learned from it. After all, one goal of this master thesis is the definition of publishing-strategy-proposals, how to make use of a transmedia storytelling system.

The survey was implemented online with the service of the "Survio", a Czech company that offers a solution for online surveys. The target audience is consumers of fantasy content in Germany, and the survey was active for 22 days. The minimum of participants is limited to one hundred people.

\subsection{Methods and systematic}

The survey realization bases on three commercial transmedia franchise examples. The participant can pick only one of the examples, preferably that which the participant is most familiar with. The decision of the participant splits the survey into three paths with different examples, but with the same pathway, research object, and amount of question (see figure $07 / 8$ ). The reason why the survey bases on three different example are that it was possible to address a broader target audience.

Every transmedia franchise example has two possible so-called motherships (see chapter 3.2.), which provide enough background information about the respective storyworlds. In each example, one possible mothership is in the form of a book. The other possible mothership is a non-book media form. For the survey printed books, e-books and audiobooks are considered as one mothership, because only the narrative or content matters, not the way of its publishing.

The first example is Tolkien's storyworld Middle-Earth, represented by The Lord of the Rings or The Hobbit. All examples will get a detailed description and classification in the further proceeding (see Chapter 5.1.1 and 5.1.2), but for now, the pathway of the survey will be explained on the examples of The Lord of the Rings franchise. 


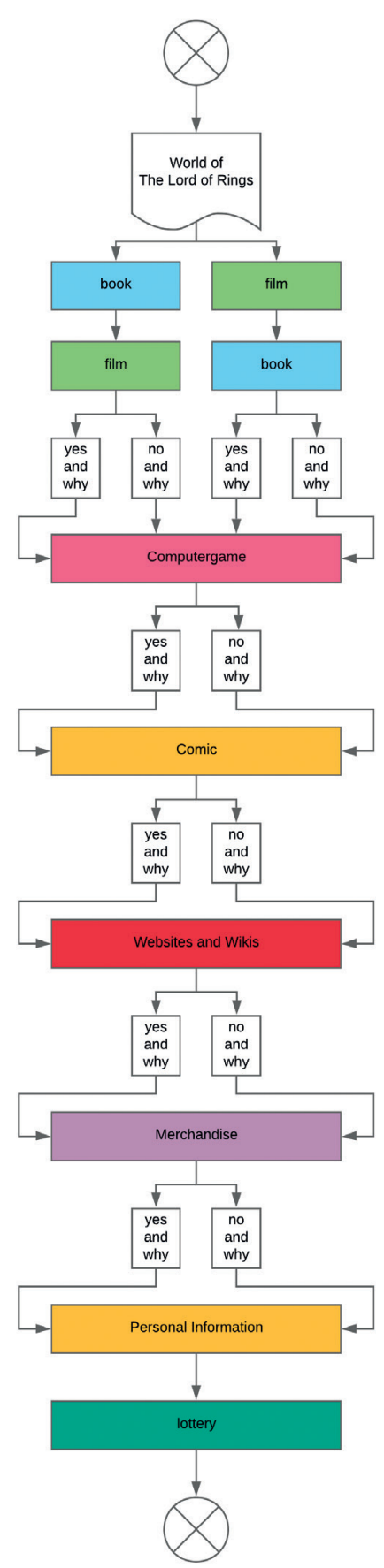

The transmedia storytelling franchise of The Lord of the Rings offers two possible motherships that provide enough information for the consumer to gain a deeper understanding of the storyworld of Middle-Earth. For this example, the possible motherships are the films of The Lord of the Rings or The Hobbit trilogy or their own books. So the participant decides what mothership he or she consumed first in his or her life. In the next step, the participant provides information on whether he or she also consumed the other mothership. The other media types that are called up are computer games, comics, and graphic novels, websites, and web-wikis, and lastly merchandise, and licensed products, such as board and card games.

At the end of the survey, the participant should provide some personal information to work out further sub-target audiences. Furthermore, the participant could take part in a lottery. After gathering the information of the survey, the results of all three pathways were merged into one total result.

The survey was created with the help of the Survio service, published and spread on the university distribution board, various online fantasy forums, and fan communities of the example franchises.

It follows a description of every transmedia franchise example and an explanation of why these examples have been chosen for the survey, as well as the gathering of the personal data of the participants.

Figure 9 Pathways of the survey (Source: Personal collection). 


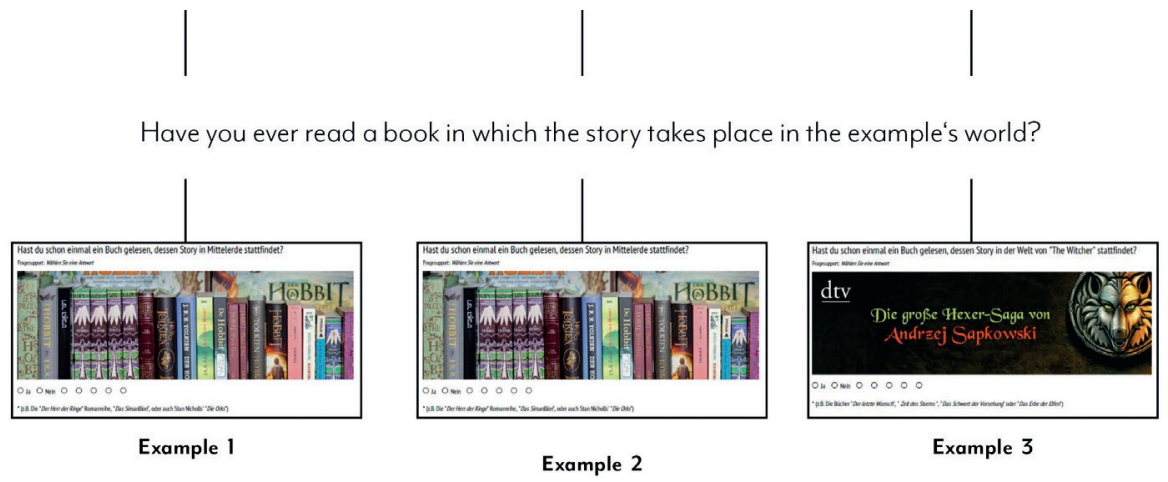

Figure 10 Pathways of the survey (Source: Personal collection).

\subsubsection{Description of the examples}

This chapter describes the three transmedia storytelling franchise examples for the survey and exposes the components of the examples that turn it into a transmedia storytelling system. Furthermore, it verifies the example's classification to the genre fantasy. The aspects and theories in the previous chapters are the basis for this description with the use of the thereof coming specialized terminology. The examples are J.R.R. Tolkien's storyworld of Middle-Earth (The Lord of the Rings, The Hobbit), G.R.R. Martins storyworld of A Song of Ice and Fire or Game of Thrones, and lastly Andrzej Sapkowski's storyworld of The Geralt Saga or The Witcher.

\subsubsection{Tolkien's storyworld of Middle-Earth}

The storyworld around Middle-Earth was created by British novelist John Ronald Reuel Tolkien ( $\left.{ }^{*} 1882-1973\right),{ }^{144}$ first published in the 1930s in the form of books. The first book that a story takes place in Middle-Earth was the book "The Hobbit: Or There and Back Again", first published in 1937. ${ }^{145}$ Further stories from Middle-Earth followed, such as "The Lord of the Rings (1954-1955)"146, "The Silmarillion (1976)", or "Unfinished Tales of Númenor and Middle-Earth (1980)". Tolkien's stories about Middle-Earth transferred into more media types, such as animated cartoons, films, comics, computer games, and much more, at the end of the 20th century. The probably most famous story about Middle-Earth is The Lord of the Rings, with over 50 million sold copies of the trilogy worldwide. ${ }^{147}$

\footnotetext{
144 Brockhaus Enzyklopädie Online: J.R.R. (John Ronald Reuel) Tolkien. NE GmbH | Brockhaus, 2019, https://brockhaus.de/ecs/permalink/A1BA1B4B7AAE49FCAF2DE3A90D44B222.pdf [last accessed on 2019.10.18].

145 See fn 3.

146 See fn 3.

147 Brockhaus Enzyklopädie Online: Der Herr der Ringe. NE GmbH | Brockhaus, https://brockhaus.
} 
The secondary world of these stories is "Arda", which contains the continents Valinóre, Middle-Earth, the Island Númenor, and Ea, the universe around Arda. The unity of these places is called "Legendarium"148. Most of the published stories take place in Middle-Earth. Arda distinguishes itself from the primary world by different geography, physical impossibilities, and the functioning of metaphysical power. Furthermore, the society and the state of technology inside the stories are on the level of the Middle Ages of our primary world.

The metaphysical power is implemented in the form of magic and offers a vast fantasy inventory - for example, orcs, dragons, dwarfs, magical rings, and gems.

Nearly all stories reveal a heroic element. In the case of The Lord of the Rings, Frodo Baggins and The Fellowship of the Ring are the protagonists who try to destroy the One Ring and save Middle-Earth from downfall. The antagonists are Sauron, an evil ghost-being, Saruman, a corrupted wizard, who seek to keep the One Ring for themselves and use it to subjugate Middle-Earth. All heroes use special metaphysical abilities to reach their goals. The quest is to destroy the One Ring and save Middle-Earth from demise or on the contrary, take the One Ring to gain absolute power and subjugate Middle-Earth. ${ }^{149}$ These aspects build a fantasy structure.

Some works such as The Silmarillion offer peripheral stories for the canonic stories of The Lord of the Rings or The Hobbit, explaining the history, ethics, and folklore of Arda. Furthermore, they provide self-contained stories that work as a prequel to other stories. In conclusion, all these stories build a transfictional system. At the end of the 20th century and the beginning of the 21st century, a lot of new stories expanded this system through different media types - for example, the computer game Middle-Earth: Shadow of Mordor (2014) tells a story that blends into the transfictional system smoothly, and that has never been told before. ${ }^{150}$ Such media turns the Legendarium of Tolkien in a transmedia storytelling system.

In conclusion, this example fits into the genre fantasy smoothly and offers an already built transmedia storytelling system.

\subsubsection{A Song of Ice and Fire / Game of Thrones}

The second example is A Song of Ice and Fire, a series of novels written by American novelist George Raymond Richard Martin, which builds the basis for the TV drama series Game of Thrones, aired by HBO. The novel series consists of five volumes, and two more are planned. The first volume was published in 1996, and until yet, A Song of Ice and Fire sold over 58 million copies worldwide. ${ }^{151}$ In recent years, the story has

de/ecs/permalink/F7784296CDF8E9BD91A87AA3455E4398.pdf [last acccessed on 2019.10.18].

148 Ardapedia: Legendarium. Ardiapedia, 2019, http://ardapedia.herr-der-ringe-film.de/index.php/

Legendarium [last accessed on 2019.10.18].

149 Ardapedia: Der Herr der Ring. Ardapedia, 2019, http://ardapedia.herr-der-ringe-film.de/index. php/Der_Herr_der_Ringe [last accessed on 2019.10.18].

150 Ardapedia: Mittelerde: Mordors Schatten. Arapedia, 2019, http://ardapedia.herr-der-ringe-film.de/ index.php/Mittelerde:_Mordors_Schatten [last accessed on 2019.10.18].

151 A Song of Ice and Fire Wiki: A Song of Ice and Fire, FANDOM Books Community, Fandom, Inc., 
been adapted as board games, card games, computer games, graphic novels, and further books that enrich the core story.

The story takes place in a fictional world, primarily upon two continents called Westeros and Essos. The geography of the world is different from the primary world, and the social system conforms with the Middle Age and ancient times of the primary world. Furthermore, the functioning of metaphysical power in the form of magic separates the secondary world from the primary world. It also provides a fantasy inventory consisting of dragons, undead warriors, and magical material. ${ }^{152}$

The story reveals many heroes that are indistinguishable neither from the protagonist nor the antagonists. The story is written from the point of view of different characters and deals with civil wars, political integration, and surviving through various wars and catastrophes. Nevertheless, there are two major characters, each with a superior quest: Daenerys Targaryen, who tries to take back her kingdom with the help of three dragons and John Snow, who works to prevent the demise of Westeros by the White Walkers, an undead army. These components built the heroic element and fantasy structure of the story. ${ }^{153}$

The storyworld by G.R.R. Martin offers many possibilities for the content design and story arcs, by establishing an extensive social system based on aspects of aristocracy and monarchy. He already published peripheral stories, such as "Fire and Blood" (2018), a historical background story for the fictional noble house of Targaryen, or "The Wit \& Wisdom of Tyrion Lannister" (2013), which illustrates a single character very profoundly, to enrich the core story. Other companies released computer games that tell side stories from noble houses of Westeros.

In conclusion, the storyworld around Westeros and Essos is part of a transfictional and transmedia storytelling system and belongs to the fantasy genre by matching all main traits.

\subsubsection{The Geralt Saga/The Witcher}

The last example is a paradigm for classic transmedia storytelling with the slightest scope for discussion from all three examples. The Polish novelist Andrzej Sapkowski published the first book of the Geralt Saga in 1990. He published a variety of short stories, followed by a series of five novels (1994 - 1999). In 2007 The Witcher, a computer role-playing game based on Sapkowski's novels, developed by $C D$ Project RED, was released in Europe. The plot of the game is set five years after the events of Sapkowski's latest novel from the Geralt Saga. ${ }^{154}$ CD Project RED released two more significant games in 2011 and 2015 that chronologically extend the story of the Geralt Saga,

2019, https://iceandfire.fandom.com/wiki/A_Song_of_Ice_and_Fire [last accessed on 2019.10.18].

152 See fn. 10.

153 See fn. 10.

154 Witcher Wiki: CD Project's The Witcher Franchise. FANDOM Games Community, Fandom, Inc., 2019. https:/witcher.fandom.com/wiki/CD_Projekt\%27s_The_Witcher_franchise [last accessed on 2019.10.18]. 
and they developed and licensed a range of other games that are part of this storyworld. In conclusion, CD Project RED establishes and controls The Witcher franchise that contains a series of computer games and graphic novels, based on Sapkowski's Geralt Saga. In December 2019, the streaming provider Netflix will release a video series of The Witcher.

The story of the Geralt Saga takes place on an unnamed planet that resembles the primary world, but has another geography, and magic is functioning. The setting of the world conforms to the Middle Ages of the primary world, as the previous examples did.

Furthermore, the unnamed planet is linked with other dimensions in a multiverse on a route called Spiral, which intensifies the distinction from the primary world. ${ }^{155}$ The story of the Geralt Saga often refers to the fairytales of Brothers Grimm and other folk tales. A point of criticism could be that the novel addresses the primary world and harms the inner coherence and seriousness of the secondary world. However, in my opinion, it is a simple persiflage, and the secondary world is still self-contained and preserves its inner coherence and seriousness. Moreover, Weinreich posited that fantasy stories often refer to myths and folk tales from the primary world..$^{156}$

The metaphysical power is the basis for a considerable fantasy inventory consisting of several monsters, werewolves, vampires, magical objects, and even traveling through different dimensions.

The main protagonist of the saga is Geralt of Rivia, a so-called witcher, which is a mutated monster-slayer. Besides Geralt, there is his adoptive daughter Cirilla, the sorceress Yennefer of Vengerberg, and Geralt's companion. Geralt travels across the world and hunts monsters and ghosts against payments. As he adopts Cirilla, his quest is to keep her safe and rescue her from the force of evil wizards, political schemes, and hunting ghosts, which reach out for her.

In the case of the Geralt Saga, it is easy to recognize the transmedia storytelling system by the computer games that tell the story along, starting from the end of the novel series. The storyworld also matches the traits of the fantasy genre.

\subsubsection{Justification and classification}

A lot of commercial fantasy franchises came up in recent decades, and there was a big choice of examples that could have been chosen for the survey. For example, the Harry Potter and Star Wars franchises are good examples of transmedia storytelling, too. Although it is debatable on whether Star Wars should be classified to the fantasy or science fiction genre. In my opinion, Star Wars matchs all traits of a fantasy genre with the possible exception of the secondary world. Nevertheless, the story of Star Wars contains a heroic element, metaphysical power (in this case, the force), the

155 Witcher Wiki: The Witcher series. FANDOM Games Community, Fandom, Inc., 2019. https:// witcher.fandom.com/wiki/The_Witcher_series [last accessed on 2019.10.18].

156 Weinreich, Frank: Fantasy - Einführung (Essen: Oldib Verlag Oliver Bidlo, 2007) page 64 et seq. 
absence of the primary world, and it is possible to gather a fantasy inventory or recognize a fantasy structure. So, Star Wars and Harry Potter would be good examples of transmedia storytelling franchises, too.

The reasons why they are not part of the survey lay in the similarities of the chosen storyworld examples, and the differences between the storyworld of Harry Potter or Star Wars and the selected examples. As figure09 reveals, the examples differ in the setting and similarities of the secondary world to the primary world.

The chosen examples are having a storyworld that is geographically different from the primary world, and all the social setting conforms to the Middle Ages of the primary world.

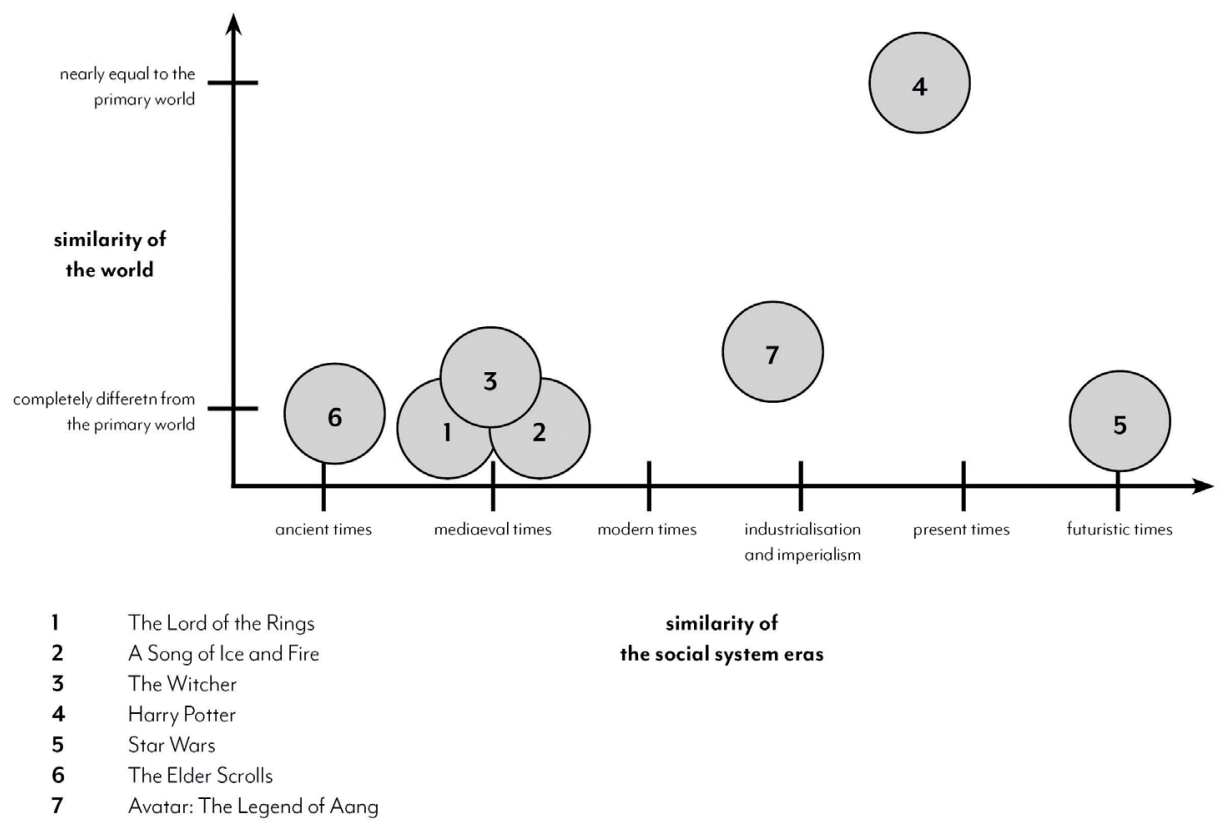

Figure 11 Fantasy world mapping (Source: Personal collection). 


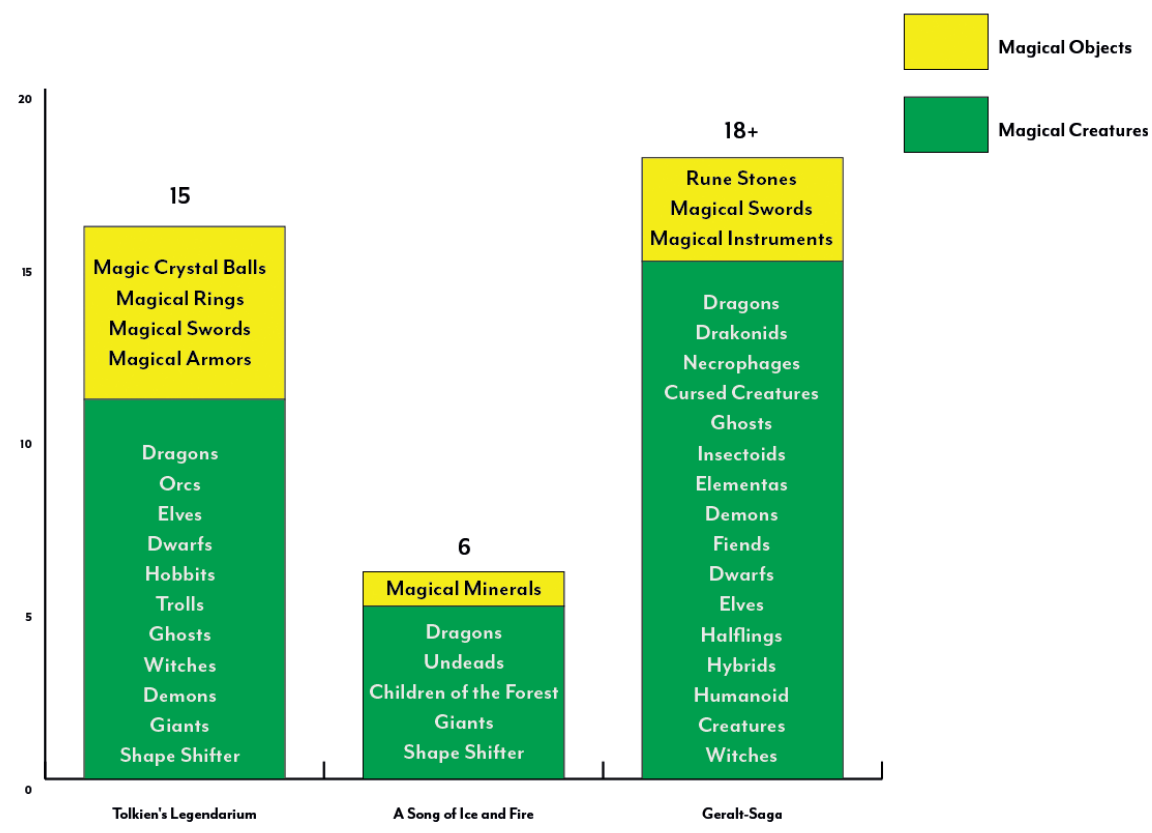

Figure 12 Fantasy inventory of each example (Source: Personal collection).

Furthermore, there are differences and similarities in the fantasy inventory between all possible examples. All types of magical creatures and objects were counted and displayed in figure10 to picture this issue.

In conclusion, the storyworld of Tolkiens Legendarium, G.R.R. Martins A Song of Ice and Fire, and Sapkowski's Geralt Saga have a very similar fantasy structure, social setting, and design of each storyworld. Therefore, these examples have been chosen for the survey to ensure that a consistent target audience participates in the survey, despite using three different samples.

\subsubsection{Gathering of personal data}

At the end of the survey pathway, the participant provides information about his or her gender, age, and job situation. Such information could enable a conclusion about the consumer's resources for fantasy transmedia storytelling franchises and supports a more accurate definition of a possible target audience.

The options for the question of the job situations are: 
- Full-time employed

- Part-time employed

- University/ college student

- School student

- Trainee

- Currently unemployed

These are the standard options for a job situation in Germany. Such information possibly provides conclusions about the available time that a single consumer has to spend on fantasy media. The employee-life-cycle is the basis for the rage of the participant's age, as well as the possible time range from the oldest publication of all three examples.

Moreover, the employee-life-cycle links information about the participant's age with his/her job situation and resource of available time. The employee-life-cycle describes the succeeding cycles of an employee's career. It is a standard tool in human resource management and control.

The time range from the oldest publication of all three examples is set on 62 years, from 1957 until 2019. The most previous book is Tolkien's “The Hobbit: Or There and Back Again”, originally published in 1937 in the United Kingdom and 1957 in Germany. So based on these references, the options for the ages were set as follows:

- $\quad 12-17$ years old

- 18-24 years old

- 25-35 years old

- 36-49 years old

- 50-62 years old

- Over 62 years old

The first age range relates to students from middle and high school. Generally, most German school students absolve their high school at the age of 18 and begin their study approximately at the age of 21. ${ }^{157}$ Furthermore, reports of a German book trade weekly, ${ }^{158}$ and the JIM study ${ }^{159}$ confirm that in this age range, young people start to read and purchase books independently. Last but not least, most media adaptions, such as films and computer games, have an age limit of 12 or 16 years.

157 German Federal Office of Statistics: Durchschnittsalter der Studienanfänger/-innen im ersten Hochschulsemester in Deutschland von 1995 bis 2017. Statista. Statista GmbH, 2018. https://de. statista.com/statistik/daten/studie/36660/umfrage/durchschnittsalter-der-studienanfaengerseit-1995/ [last accessed on 2019.10.14].

158 Börsenblatt: Umfrage zu Selbstkäufen bei Kindern, 2018. https://www.boersenblatt.net/2018-02-11artikel-junge_leser_in_der_buchhandlung-umfrage_zu_selbstkaeufen_bei_kindern.1430056. html [last accessed on 2019.10.10].

159 Jugend-Inforamtion-Medien: Leseverhalten von Jugendlichen, 2019. http://www.lesen-indeutschland.de/html/content.php?object=journal\&lid=1565 [last accessed on 2019.10.10]. 
The second age range relates to trainees and students of university and college. The average age of a German university graduate is $24 .{ }^{160}$ Most German trainees absolve their job training at the age of 21 by a report of the federal institute for industrial training. ${ }^{161}$

The third age range conforms to the expansionary cycle of the employee-lifecycle when graduates start working in an organization and develop a career.

The fourth age range relates to the transition from the expansionary to the social cycle, when the employee already reached a special status and took over professional or even senior responsibilities within his/her company.

The fifth age range conforms to the social cycle altogether, and the employee devotes his/her resources to the mentoring and training of younger employees.

The last time range relates to people that could have experienced the first possible books of the examples in the German market and are probably in pensionable age.

The gender options are male, female, and diverse.

\subsection{Results of the survey}

In total, 683 people have participated in the survey, but 12 participants stated that they have never consumed one of the samples until now. Therefore, these people must cancel the survey, and consequently, the survey gained only 671 valid participants in total. One hundred twelve people consumed only one of the samples, 295 consumed two, and 264 consumed all of the three given examples. ${ }^{162}$ A summarized extract of all essential results follows. For a detailed view of all results, see attachments A1 (total results of the survey) and A2 (detailed results and pathway of the survey). In the discussion, references to the detailed and total results from the attachments will often appear, too.

The analysis of the personal data reveals that 423 participants are female, 245 are male, and three are from a diverse gender. So the amount of female consumers of fantasy media is considerably higher than the others.

160 German Federal Office of Statistics: Durchschnittsalter von Hochschulabsolventen* in Deutschland in den Prüfungsjahren von 2003 bis 2017 (in Jahren). Statista. Statista GmbH, 2018. https://de.statista. com/statistik/daten/studie/189237/umfrage/durchschnittsalter-von-hochschulabsolventen-indeutschland/ [last accessed on 2019.10.14].

161 German federal institute of industrail training: data report, 2015 (see attachement A3)

162 See attachment A1) 


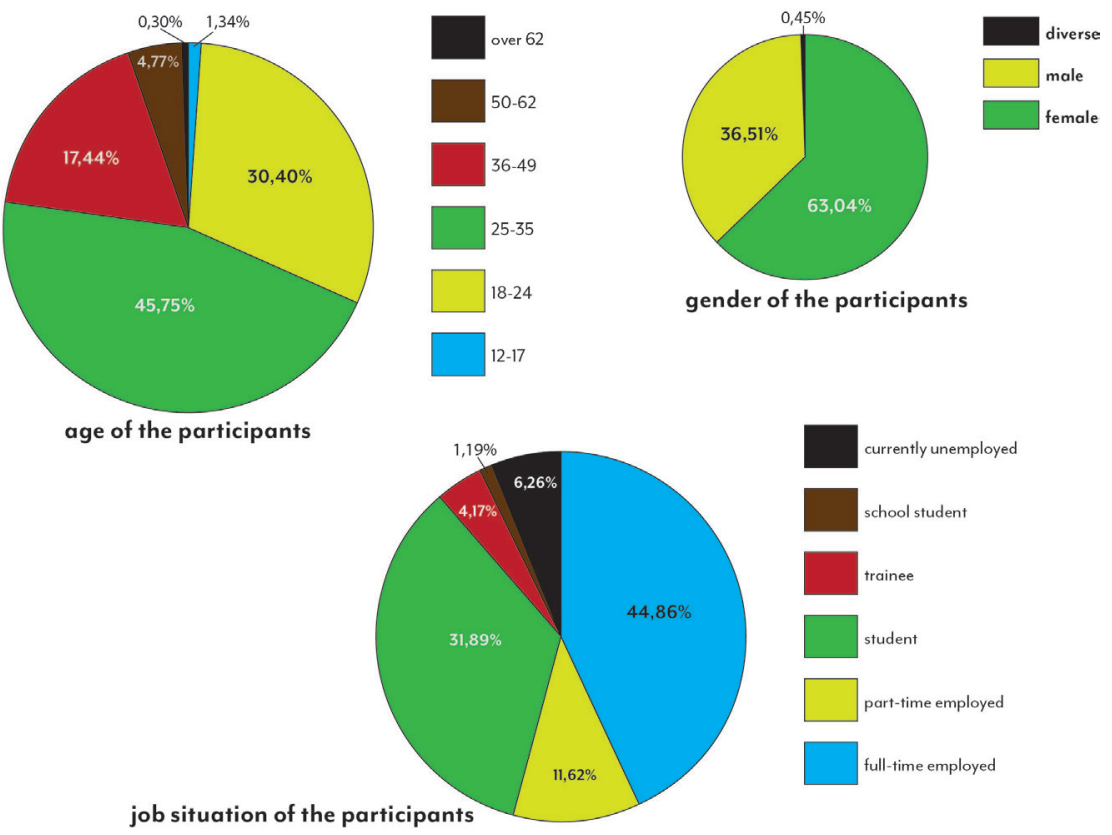

Figure 13 Results - personal data (Source: Personal collection).

The most significant share of all participants is between 25 and 35 years old and fulltime employed. The second biggest share is between 18 and 24 years old and considerably fitting to university or college students. The participants who are between 35 and 62 years old represent pooled $22.41 \%$ of the total. The participants who are older than 62 years and younger than 18 years represent only a small share of the survey. Trainees, part-time-employees, and unemployed people represent pooled $22.05 \%$ of the total survey participants, too. The school students represent the smallest share, which fits the results of the participant's age.

The next result shows the breakdown of the participant's mothership between book- and non-book-media. For Tolkien's Legendarium, the mothership could be the books or the films. The same applies to A Song of Ice and Fire for that the books or the TV series Game of Thrones provide the most background information. Only for the Geralt Saga, the medium that provides enough background information, besides the books, are computer games by CD Project RED. 


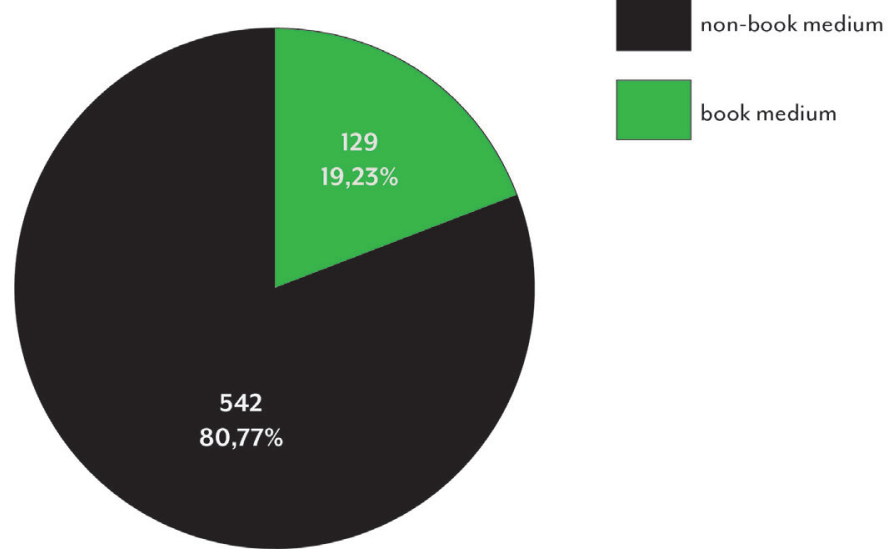

Figure 14 Results - mothership types (Source: Personal collection).

The result shows that the number of motherships that are a non-book media type is considerably higher, with $80.77 \%$ from total than motherships in the form of books with $19.23 \%$ from the total.

The following result illustrates how the further consumption of the same storyworld spreads across the different media types, starting from the first touchmothership.

Tab. 2 Result - further consumption.

\section{Count of}

Participants

Relative to Total (671)

\begin{tabular}{lll}
\hline Further consumption by Books & 305 & $45.45 \%$ \\
\hline Further consumption by Films/ Series & 203 & $30.25 \%$ \\
\hline Further consumption by Computer Games & 191 & $28.46 \%$ \\
\hline $\begin{array}{l}\text { Further consumption } \\
\text { by Comics/Graphic Novels }\end{array}$ & 148 & $22.06 \%$ \\
\hline Further consumption by Websites/Wikis & 536 & $79.88 \%$ \\
\hline Further consumption by Merchandise & 398 & $59.31 \%$
\end{tabular}

The analysis reveals that most participants use Websites and Online Wikis and Merchandise products for further consumption. Nearly half of all participants that started from a non-book mothership had read a book of the same storyworld afterwards. By each third, the participants used films, series, and computer games for further consumption. The smallest share of further consumption represents comics and graphic novels.

The next figure shows for each media type the reason why the participants made their choice. They had a choice between these options: 
- The participant wants to learn more about the storyworld and the creatures and objects living in it (desire for transmedia storytelling).

- The participant wants to re-experience the story on another media (desire for adaption).

- The participant wants to connect oneself with other fans (possible options for websites and online wikis).

- The participant wants to read fanfictions (possible options for websites and online wikis).

- The participant wants to publish fanfictions (possible options for websites and Online wikis).

- The participant wants to reveal his-/herself as a fan of the franchise (possible options for websites and online wikis).

- Other reasons (text input).

The main reason why the survey was created is to research whether people are willing to consume media inside a transmedia storytelling system and if media agencies should rely on adaption, preferably, or should they spread the further storyworld across various media channels. Therefore, for the result analysis, all options besides "learn more about the storyworld and the creatures and objects which living in it" (reason A) and "re-experience the story on another media" (reason B) are summarized as "other reasons" (reason $\mathrm{C}$ ).

The results reveal that reason A represents the most significant share of all media types except merchandising products. Especially for websites and online wikis is the share of reason A considerably higher than for the other reason. The same relation applies to books, films/ series, computer games, and graphic novels, just in another amount and ratio. Reason $B$ represents the second biggest share for books, films, series, comics, and especially for computer games. This reason does not appear as an option for websites, online-wikis, and merchandise products because the common purpose of these media forms does not allow to display an adaption of the mothership's stories of adequate quality. Reason $\mathrm{C}$ represents a small amount for the further consumption of websites and online wikis, but the considerably highest share for merchandising products. The most frequent reason for merchandising products was the willingness to reveal oneself as a fan of the franchise, with approximately $77 \%{ }^{163}$ of all given reasons for this media type.

The following result reveals the reasons why the participants do not have further consumption or refuse a further consumption of each media type. A participant could choose between five options why the interviewee did not use the respective media type for further consumption:

- The participant has no interest in further consumption because of the story world's proposal for this media type. 
- The participant is not able to consume the particular media type - for example, because of missing hardware, devices, or physical handicaps.

- The participant generally refuses to use this media type.

- The participant has not yet managed to consume the storyworld on the respective medium but is still interested in doing so.

- Other reasons (text input).

For the media type "merchandising products" the option "The participant is not able to consume the respective media type - for example, because of missing hardware, devices or physical handicaps." was not available, because merchandising products are so manifold and include so many diverse products that it is very implausible that the participant cannot use anything of it. For books, films, and series, most participants stated that they have not yet managed to consume this media, but they are interested in doing so.

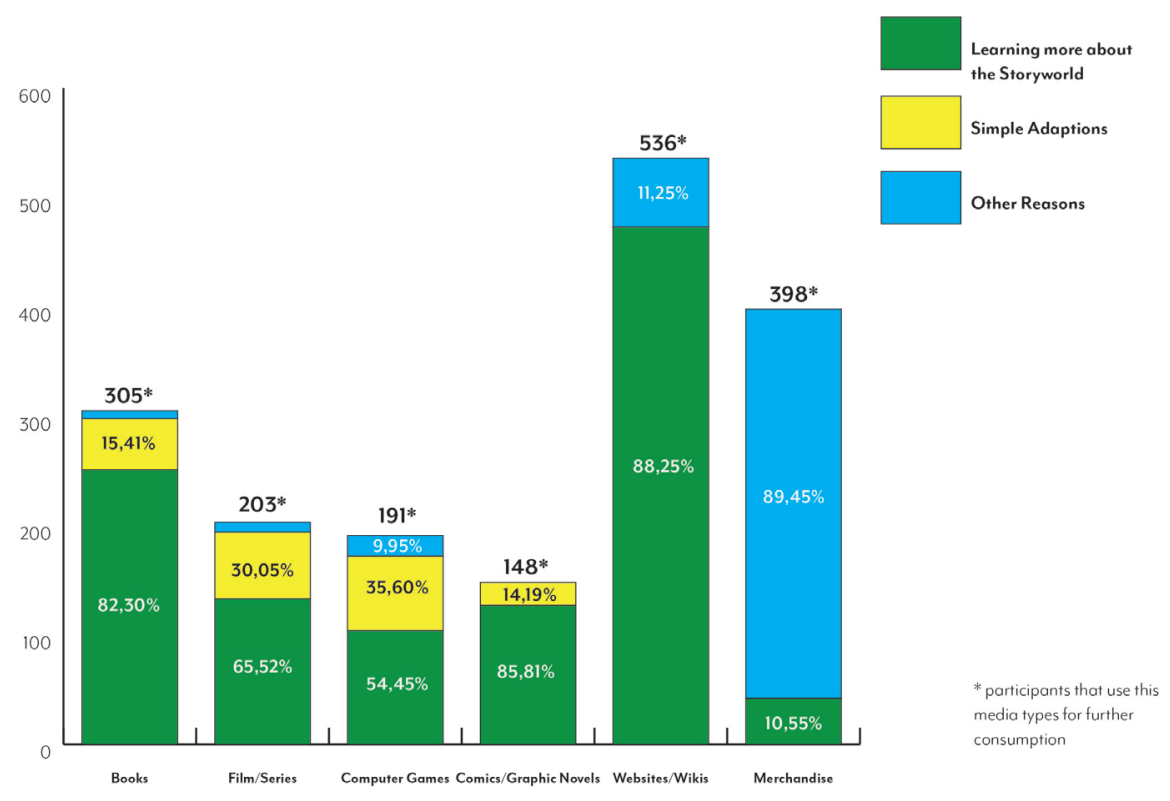

Figure 15 Results - reasons for further consumption (Source: Personal collection). All amounts under $5 \%$ are not displayed with percental data to obtain a better lucidity.

For computer games, comics, and merchandising products, most participants stated that they do not consume these types of media generally. This relation applies especially to comics and graphic novels, where approximately $51 \%$ stated so. The second biggest share for computer games and comics represents participants that are interested in consuming these media types, with approximately 26\% (computer games) and $28 \%$ (comics). This share is closely followed by participants that have no interest in the proposal of a particular storyworld, with approximately $22 \%$ for computer 
games and $13 \%$ for comics and graphic novels. For websites and online-wiki, the breakdowns of the options differ considerably from the other media types. Approximately $45 \%$ of the participants who have not to use this media type states that they are not interested enough in the website's and online wiki's proposals, which belong to a particular storyworld. Approximately $25 \%$ of the participants stated that they do not use websites and online wikis for further consumption in general, and the nearly equal share stated that they are still interested in using it in the future.

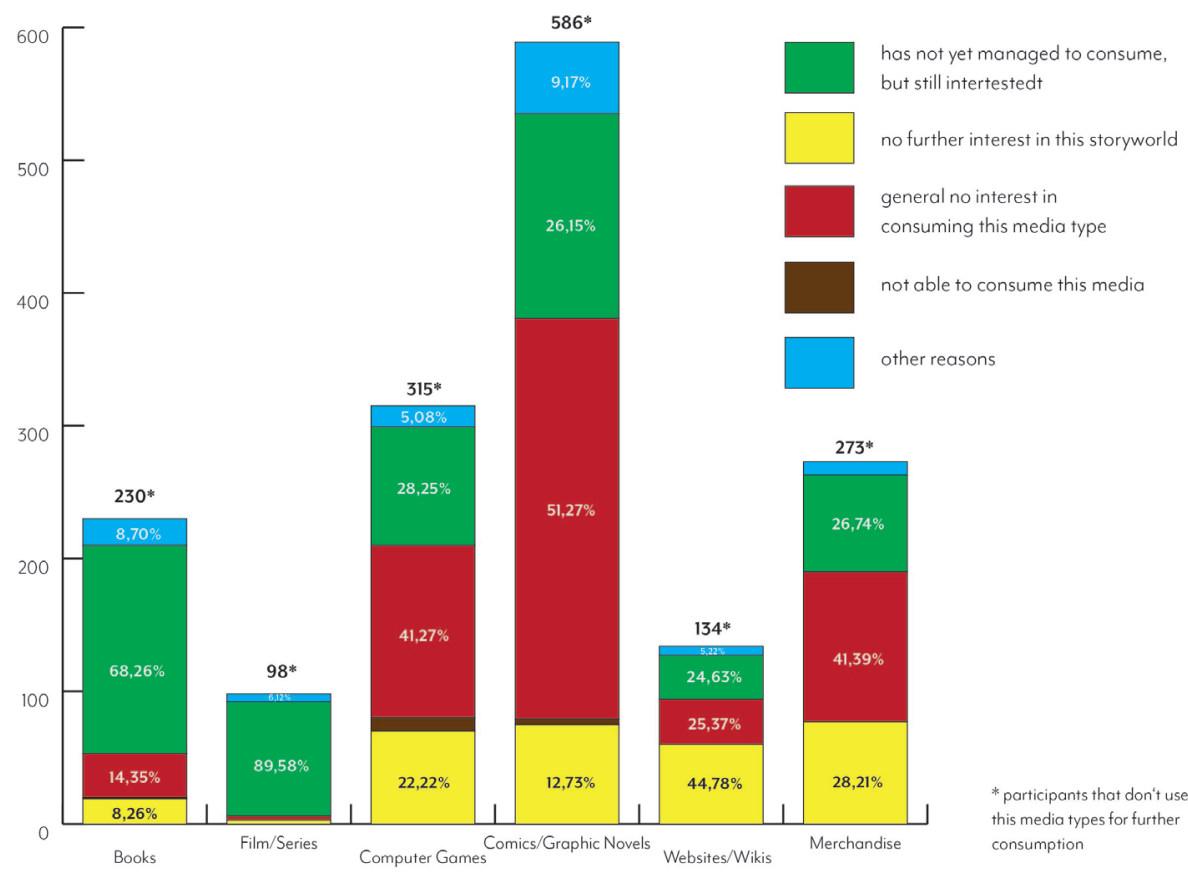

Figure 16 Results - reasons for further non-consumption (Source: Personal collection). All amounts under 5\% are not displayed with percental data to obtain a better lucidity 



\section{Discussion of the Perceptions}

This final chapter interprets and discusses the results of the survey and their meaning/ significance for the media market and especially for the setup, maintenance, and development of a transmedia storytelling system. Based on this interpretation and discussion, this chapter will define strategic theses for publishing houses and media agencies, how they can recognize a transmedia storytelling franchise, how they can build such a system, and make a profit by maintaining it. The last part of this chapter is the answering of the research questions by summarizing all relevant perceptions.

\subsection{Interpretation and discussion of the survey's results}

The interpretation and discussion of the survey's results set the focus on a closer definition of the target audience first. Then it continues with the focus on further consumption across various media types. The last point is about the remaining potential of the least-selected media types and how to make use of it.

\subsubsection{Interpretation and discussion concerning the target audience}

The analysis of the survey resulted in the existence of two closer defined target audiences of transmedia fantasy consumers. They are the most relevant audiences by representing approximately $75 \%$ of all interviewees that have engaged with fantasy media explicitly. The first target audience is between 18 and 24 years old and currently studying at college. The second and bigger target audience is between 26 and 49 years old and full-time employed. These target audiences overlap in some points; for instance, in the share of female consumers, which is considerably more considerable for both target-audiences. Nearly two-thirds of all interviewees are female. However, these target-audiences differ in their available resources of time and money. One can assume that people who are working in full-time employment have more available financial resources than a college or university student. However, the financial resource depends not only on how much a consumer earns, but the amount of fix and variable costs is also relevant. So even when a full-time employed person earns a a significantly higher amount of money as a student does in the same period, the fix costs could be so considerably high that both result in the same financial resource for fantasy media consumption. For example, maintenance costs of cars, pets or children, rental charges, costs of energy, and healthcare costs can differ from person to person. The same applies to the resources of time. First, one can assume that a student has a more significant resource of time as a full-time employed person. However, in Germany, 51.5\% of all students have part-time employment in 
addition to their university studies in 2011. ${ }^{164}$ Therefore, the student's resource of time for fantasy media considerably is not higher than of a full-time employed person, and it could be even less alongside a full-time studying. That is why, the ratio of salary to fix costs in terms of the current living conditions has also a crucial impact on the financial and time resources of these two target audiences.

Nevertheless, an indicator of the assumption that full-time employed persons have higher financial resources than students is recognizable by taking a closer look at the data of each survey's example. From this view, $47.2 \%{ }^{165}$ of all participants who have chosen the A Song of Ice and Fire storyworld and 56.4\% ${ }^{166}$ of all participants who have chosen the Geralt Saga storyworld are full-time employed. This group represents the most significant share for each of these two examples. Only for Tolkien's Legendarium, the university students represent the most significant share with $41 \%{ }^{167}$. This circumstance could relate to the topicality, the footage, and carrier medium of each series that is suitable for being a transmedia storytelling mothership. The gathering of information for these factors (see table 03) reveals that Tolkien's storyworld, both in the book and non-book media, is the least current and has the lowest prices for films and books. Furthermore, the book and film series of Tolkien's storyworld consist of only one to three books or film.

In contrast to Game of Thrones or A Song of Ice and Fire with ten books or 73 episodes, this is considerably low and, therefore, it is less expensive to consume the whole story. For instance, to consume the whole story of Game of Thrones on DVD, a person must pay a bundled price of about $114.95 € .^{168}$

In contrast, the whole Middle-Earth collection, which contains both The Lord of the Rings and The Hobbit Trilogies, has a bundled price of about $14.97 € .^{169}$ Such a difference in prices could encourage university or college students to choose the media of Tolkien's storyworld, preferably, based on the assumption that students have smaller financial resources than full-time employed people. So, in that sense, this issue could be an explanation of why more students have consumed Tolkien's Legendarium than full-time employed people.

\footnotetext{
164 See attachment A2.

165 See attachment A1.

166 See attachment A1.

167 See attachment A1.

168 Prices on Amazon on 2019.11.02.

169 Prices on Amazon on 2019.11.02.
} 
Tab. 3 Resource investment per example.

\begin{tabular}{|c|c|c|c|c|c|}
\hline $\begin{array}{l}\text { Survey's } \\
\text { Example }\end{array}$ & $\begin{array}{l}\text { Possible } \\
\text { Mothership }\end{array}$ & $\begin{array}{l}\text { Carrier } \\
\text { Medium }\end{array}$ & $\begin{array}{l}\text { Series } \\
\text { Extend }\end{array}$ & $\begin{array}{r}\text { Publishing } \\
\text { Period }\end{array}$ & $\begin{array}{l}\text { Lowest Price } \\
\text { by Amazon.de }\end{array}$ \\
\hline \multirow{4}{*}{$\begin{array}{l}\text { Tolkien's } \\
\text { Legendarium }\end{array}$} & \multirow{2}{*}{$\begin{array}{l}\text { The Lord of } \\
\text { the Rings }\end{array}$} & Films & 3 & 2001-2003 & 9.99€ per DVD \\
\hline & & Books & 3 & 1969-1970 & $\begin{array}{r}15.00 € \text { per } \\
\text { book }\end{array}$ \\
\hline & \multirow[t]{2}{*}{ The Hobbit } & Films & 3 & 2012-2014 & $10.49 €$ per DVD \\
\hline & & Books & 1 & 1957 & $\begin{array}{r}10.00 € \text { per } \\
\text { book }\end{array}$ \\
\hline \multirow[t]{2}{*}{$\begin{array}{l}\text { A Song of Ice } \\
\text { and Fire }\end{array}$} & $\begin{array}{l}\text { A Song of Ice } \\
\text { and Fire }\end{array}$ & Books & 10 & $1996-2011$ & $\begin{array}{r}16.00 € \text { per } \\
\text { book }\end{array}$ \\
\hline & $\begin{array}{l}\text { Game of } \\
\text { Thrones }\end{array}$ & TV Series & $\begin{array}{r}73 \text { episodes in } \\
8 \text { seasons }\end{array}$ & 2011-2019 & $\begin{array}{r}20.00 € \text { per DVD } \\
\text { Box (single } \\
\text { season) }\end{array}$ \\
\hline \multirow[t]{2}{*}{$\begin{array}{l}\text { The Geralt- } \\
\text { Saga }\end{array}$} & $\begin{array}{l}\text { The Geralt } \\
\text { Saga }\end{array}$ & Books & 7 & 1990-1999 & $\begin{array}{r}11.00-16.00 € \\
\text { per book }\end{array}$ \\
\hline & The Witcher & $\begin{array}{l}\text { Computer } \\
\text { Games }\end{array}$ & $\begin{array}{l}3 \text { Main- } \\
\text { Games }\end{array}$ & $2007-2016$ & $\begin{array}{r}25.00-70.00 € \\
\text { per game }\end{array}$ \\
\hline
\end{tabular}

A further and even stronger indicator of the assumption that full-time employed persons have higher financial resources than students was revealed by a statistic of VuMA. The VuMA is a German syndicate for media market and consumption analysis. The statistic compares the monthly net earnings of students witht the rest of the German population. The analysis of the data reveals that $19 \%$ of all students have no net income, $21.6 \%$ earn less than $500 €$ per month, $42.7 \%$ earn between $500 €$ and $1,000 €$ per month, $15 \%$ earn between $1,000 €$ and 1,500€ per month, and only $1.7 \%$ earn between $1,500 €$ and $2,000 €$ per month. ${ }^{170}$ Therefore, $83.3 \%$ of all students have a monthly net earning of less than $1,000 €$ per month. In contrast, $62.9 \%$ of the rest of the German population has a monthly net earning over 1,000€ per month. $25.9 \%$ of the rest of the German population gets even more than 2,000€ per month. ${ }^{171}$

A further statistic reveals that the Germans spend an average of $879 €$ per month on accommodation costs, an average of $348 €$ per month on nourishment, and only an average of $256 €$ per month on entertainment, spare-time activities, and culture. ${ }^{172}$ Based on the data, that most students have a monthly net income of less than $1,000 €$,

170 VuMA: Studenten in Deutschland nach Nettoeinkommen im Vergleich mit der Bevölkerung im Jahr 2018. Statista, Statista GmbH, 2018, https://de.statista.com/statistik/daten/studie/860094/umfrage/ umfrage-in-deutschland-zum-nettoeinkommen-der-studenten/ [last accessed on 2019.10.24].

171 See fn. 171.

172 German Federal Office of Statistics: Durchschnittliche Höhe der Konsumausgaben je Haushalt* im Monat in Deutschland nach Verwendungszweck im Jahr 2017. Statista, Statista GmbH, 2018. https:// de.statista.com/statistik/daten/studie/164774/umfrage/konsumausgaben-private-haushalte/ [last accessed on 2019.10.24]. 
it can be assumed that their expenditures for entertainment, spare-time activities, and culture below under the average of $256 €$.

In 2017, 28.1\% of all German full-time employed people had a monthly gross income of over $2,000 €, 24 \%$ had a monthly gross income of over $3,000 €$, and $31.9 \%$ even had a monthly gross income of over $4,000 € .{ }^{173}$ So, it is very likely that even less social security and taxes, the expenses of full-time employees for entertainment, leisure activities, and culture lie within or even above the average of $256 €$.

In conclusion, it is still not possible to make clear statements about the financial resources and the resources of the time for fantasy media of both target audiences that have been revealed by the survey. The resources depend not only on the monthly net income or the degree of activity. They also depend on the current living conditions, which still need to be researched more closely. Nevertheless, the assumption that full-time employed people have more financial resources for fantasy media franchises than students is very likely, based on the analyzed data above.

In the act of studying the distribution of the gender for every survey's example, it appears that for Tolkien's Legendarium and the storyworld of A Song of Ice and Fire, the share of female consumers was considerably more significant than for the male share.

Tab. 4 Gender distribution among all examples.

\begin{tabular}{lrrr} 
& $\begin{array}{r}\text { Amount of female } \\
\text { consumer }\end{array}$ & $\begin{array}{r}\text { Amount of male } \\
\text { consumer }\end{array}$ & $\begin{array}{r}\text { Amount of diverse } \\
\text { gender consumer }\end{array}$ \\
\hline Tolkien's Legendarium & $62.3 \%$ & $36.5 \%$ & $1.2 \%$ \\
\hline $\begin{array}{l}\text { A Song of Ice and Fire/ } \\
\text { Game of Thrones }\end{array}$ & $77.2 \%$ & $22.8 \%$ & $0 \%$ \\
\hline $\begin{array}{l}\text { The Geralt Saga/The } \\
\text { Witcher Saga }\end{array}$ & $44.8 \%$ & $55.2 \%$ & $0 \%$ \\
\end{tabular}

Only in the case of The Witcher's storyworld, the male share of the consumers is more considerable than the female consumer share. Approximately $92 \%$ of all interviewees stated that they played the computer game series "The Witcher" first, and therefore, it represents the most chosen mothership of this transmedia storytelling franchise. One can assume that this could be the reason for the more extensive male consumer share. Bitkom research reveals that from a total of 1224 interviewed German gamers, $45 \%$ are male, and $41 \%$ are female. ${ }^{174}$ There is no statement on the remaining $16 \%$ of

173 German Federal Employment Agency: Verteilung der sozialversicherungspflichtigen Vollzeitbeschäftigten in Deutschland nach Einkommensgruppen (Bruttoeinkommen pro Monat) von 2011 bis 2017. Statista, Statista GmbH, 2018. https://de.statista.com/statistik/daten/studie/577307/umfrage/ verteilung-der-beschaeftigten-in-deutschland-nach-einkommensgruppen/ [last accessed on 2019.10.24].

174 Bitkom: Anteil der Computer- und Videospieler in Deutschland im Jahr 2019 nach Geschlecht. Statista, Statista GmbH, 2019. https://de.statista.com/statistik/daten/studie/315920/umfrage/anteil-dercomputerspieler-in-deutschland-nach-geschlecht/ [last accessed on 2019.10.14]. 
the interviewed people. One can assume that this $16 \%$ represents people that did not finish the interview or belong to diverse genders. However, the research supports the assumption that the slightly more significant male consumer share occurs because of a higher attraction of male consumers to computer games. Another further VuMA statistic reveals that male consumers play computer games more often in a shorter period of time than female players. In the case of The Witcher computer games series, finishing the first game takes approximately 50 game hours, ${ }^{175}$ the second game takes approximately 45 game hours, ${ }^{176}$ and the third game takes about 40 game hours for the main story and 200 game hours ${ }^{177}$ for all side stories and quests. Therefore, players that play more often could consume the story of The Witcher more consistently and are probably more involved and attracted by the storyline.

In conclusion, a possible reason for the slightly higher male consumer share for the witcher, in contrast to the greater proportion of female consumers share for both other examples, could be a higher attraction of male consumers to computer games. The referenced statistics about the playing-behavior of computer games support and confirm this assumption.

All in all, two possible primary target audiences have been revealed by the survey's results. The survey made it possible to determine the consumption of fantasy franchises to an explicit age range, a tendency of gender distribution, and two job situations that appear very often among fantasy media consumers. Some factors are still unclear, such as the living conditions, financial and time resources, and the available media equipment. It is necessary to gather further data about the consumer of fantasy franchises, to make a closer definition of the possible targetaudiences and to make clear statements to the still unclear factors mentioned above. Further surveys and interviews could help to gain such information.

\subsubsection{Interpretation and discussion in terms of further media consumption}

This subchapter interprets and discusses the results of further media consumption for various media types. Thereby, assumptions and theories about the general consumption behavior of fantasy media franchises and transmedia storytelling systems will be defined.

First, the examination of the distribution of the book and non-book mothership and the potential of book-type media are presented.

175 PC Games: The Witcher Enhanced Edition im PC Games-Test. Computec Media GmbH, PCGames.de, 2008. https://www.pcgames.de/The-Witcher-Enhanced-Edition-Spiel-38489/Tests/The-Witcher663212/ [last accessed on 2019.10.24].

176 PC Games: The Witcher 2 - Ergebnisse der Umfrage - Spielzeit, Wertung, Empfehlung. Computec Media GmbH, PCGames.de, 2011. https://www.pcgames.de/The-Witcher-2-Assassins-of-KingsSpiel-38487/Specials/The-Witcher-2-Umfrage-Ergebnis-Top-Rollenspiel-aber-Kritik-an-Aktivierung-Steuerung-und-NPCs-826911/5/ [last accessed on 2019.10.24].

177 CHIP: Witcher 3: Diese Spieldauer erwartet Sie. CHIP Digital GmbH, München, 2017. https:// praxistipps.chip.de/witcher-3-diese-spieldauer-erwartet-sie_96993 [last accessed on 2019.10.24]. 
The analysis of the survey reveals that $80.77 \%$ of all interviewees began the consumption of the chosen fantasy franchise with a non-book media type. In the case of the storyworld of A Song of Ice and Fire, it is the TV Series Game of Thrones, and in the case of the Geralt Saga storyworld, it is the computer game series The Witcher. Only $19.23 \%$ of all interviewees started from the book media type (including print-, electronic- and audiobooks).

Tab. 5 Mothership type distribution.

\begin{tabular}{lrr} 
& Book type & Non-book type \\
\hline Tolkien's Legendarium & $31 \%$ & $64 \%$ \\
\hline A Song of Ice and Fire/Game of & $13 \%$ & $86 \%$ \\
Thrones & & $92 \%$
\end{tabular}

The most obvious ratio appears for the Geralt Saga, where 92\% of the interviewees played the computer game of The Witcher series first, and only 8\% start with the books. Nevertheless, $62.4 \%$ of The Witcher consumers have read the books after playing a game of the series, and approximately $24.2 \%$ are still interested in doing so. The remaining $13.6 \%$ of The Witcher consumers have no further interest in the storyworld or to consume a book media type in general.

In the case of the storyworld of A Song of Ice and Fire, $86 \%$ of the interviewees watched the Game of Thrones TV series before they read the books. Of these people, $45.8 \%$ have already read the books after watching the TV series, and approximately $42 \%$ are still interested in doing so. The remaining $12.2 \%$ of the Game of Thrones consumers have no further interest in the storyworld or to consume a book media type in general.

For Tolkien's Legendarium, the least current example, $64 \%$ of the interviewees watched The Lord of the Rings or The Hobbit trilogy before they read the books. Of these people, $66.5 \%$ have already read one of the books after watching the films, and approximately $17.7 \%$ are still interested in doing so. The remaining $15.8 \%$ of the film-trilogy consumers have no further interest in the storyworld`s proposal or generally refuse to consume a book media type.

These results reveal a considerable sale-potential for books, ebooks, or audiobooks. Depending on the example, only a rounded of $12 \%$ to $16 \%$ of all non-book consumers cannot be encouraged to consume a book-type media. In contrast, for each example, over $80 \%$ of the consumers who have consumed a non-book media type, can be encouraged to experience the same storyworld in a book-type media.

Furthermore, the results reveal that $82.3 \%$ of all interviewees who used a book media type for further consumption want to learn more about the storyworld and all things this world contains. This reason builds the basis for the functioning of a transmedia storytelling system because it reveals a willingness of the consumer to use different media types for gaining more information about the storyworld. All in all, the most selected reason why using a media type for further consumption was to learn 
more about the storyworld, for each media type except for merchandising products. For merchandising products, approximately $77 \%$ of all interviewees want to reveal themselves as being a fan of the franchise, about $13 \%$ had other reasons, such as making gifts and something alike, and only about $10 \%$ want to learn more about the storyworld through merchandising products. ${ }^{178}$ The results for the merchandising products were not unexpected because a lot of merchandising products are not suitable to carry a storyline, such as mugs, lunch boxes, bags, and many more. Only a few merchandising products are suitable to carry a storyline, such as card games, board games, collectible action figures with accompanying booklets or information posters. For each other media type, the reasons for learning more about the storyworld, represent a share range from approximately $54 \%$ to nearly $90 \%$.

The media form, whose consumption is reasoned most for learning more about the respective storyworld, is websites or online wikis with a share of $88.25 \% .{ }^{179}$ This result is also not unexpected because online wikis, such as Ardapedia (a wiki for Tolkien's Legendarium) or The Witcher and A Song of Ice and Fire wikis powered by Fandom Inc., have the purpose of providing information to the consumer. Such information is often gathered and peer-reviewed by the fan community itself. In the case that a person is looking for a single piece of information, it is more efficient and way faster to use an online wiki than consulting the respective book, film, or computer game. See that most texts in an online wiki are in the form of a look-up entry and not in the form of a narrative, this media type usually does not contain long stories.

Nevertheless, online wikis often contain short and summarized interstitial microstories, parallel stories, peripheral stories, and user-generated apocryphal documents of fan culture, such as fan fiction. ${ }^{180}$ The results of the survey reveal that only $4.66 \%$ use websites and online wikis to read fanfictions, and even only $0.75 \%$ want to publish fanfictions. ${ }^{181}$ Three possible instances stand to reason why fanfiction only represents such a small share of further consumption. The first reason could be that the examples are not current or prevailing enough. The second reason is that the survey's distribution did not reach the potential authors and readers of fanfictions. The third reason is that online wikis and websites are not suitable for containing fanfictions. Most fanfictions are available on ebook platforms, such as Wattpad, FanFiction.net, Quotev, or Kindle Worlds. ${ }^{182}$ As a result, in many cases, an online web forum or wiki is not a suitable platform for fanfiction.

For proving the first reason, the examples were searched on the ebook platform Wattpad with the help of a fanfiction search-filter. The following amount of results appeared: ${ }^{183}$

178 See attachement A1.

179 See attachement A1.

180 See chapter 3 - TMS, page 19.

181 See attachement A1.

182 Ebook Friendly: 15 most popular fanfiction websites to explore. Ebook Friendly - ebook geek heaven, Poland, 2018. https://ebookfriendly.com/fan-fiction-websites/\# [last accessed on 2019.10.28].

183 Wattpad: Searching the catchwords "Game of Thrones", "A Song of Ice and Fire", "The Hobbit”, "The Witcher", "The Lord of the Ringe” and all respective German translations, with the searching- 
- The Witcher fanfictions: over 1000 results

- Game of Thrones fanfictions: 437 results

- The Hobbit fanfictions: over 1,800 results

- The Lord of the Rings fanfictions: 9,600 results

In contrast, searching subjects like Harry Potter have got about 16,100 results, ${ }^{184}$ One Direction (a British boy group) has got over 19,200 results, and BTS (a Korean boy group) has got over 26,800 results. ${ }^{185}$

In conclusion, the examples The Witcher/ The Geralt Saga and Game of Thrones/ A Song of Ice and Fire seem to be not current or prevailing enough to gain a widespread fanfiction community.

On the other hand, a fast check on Wattpad is not enough to make a valid statement about this assumption. The results of Wattpad display only a tendency that subjects like Harry Potter or pop culture artists have a more considerable fanfiction community, but there are many more ebook platforms to research and prove this assumption. Nevertheless, the results of the survey prove that the fanfiction community was seemingly not reached, but it could state clearly that most consumers use websites, online forums, and wikis to learn more about the storyworld. For further research, it is crucial to examine the fanfiction communities as well because fanfiction represents an essential part of a transmedia storytelling system.

For further consumption of the storyworld by comics and graphic novels, 85.81\% of all consumers stated that they had chosen this media form to learn more about the storyworld. In comparison to other media types, comics and graphic novels are the second-highest ranked by the intention of learning more about the storyworld. On the other hand, comics and graphic novels are the least selected media form for further consumption.

For the intention of learning more about the storyworld, comics and graphic novels of Game of Thrones, The Hobbit or The Lord of the Rings are not suitable. See that for these examples, adaptions, and retelling of the already existing stories are currently available. For sure, one could consume comics or graphic novels as prequel or sequel for an already consumed mothership. For instance, a person watches The Lord of the Rings trilogy, and afterward, he or she reads the comic book of The Hobbit to learn more about the storyworld and experience the prequel story that takes place before The Lord of the Rings storyline. In this view, the comic book is included in the person's transmedia storytelling experience, but this comic book does not expand the storyworld of Tolkien's Legendarium. ${ }^{186}$ The same situation applies to A Song of Ice and Fire. The graphic novels are retellings of the book series and could be included in a

filter \#ff, \#fanfictions and without these filters. https://www.wattpad.com [last accessed on 2019.10.28].

184 See Fn. 184.

185 See Fn. 184

186 Ardapedia: Der Hobbit (Comic). Ardapedia, 2019. http://ardapedia.herr-der-ringe-film.de/index. php/Der_Hobbit_(Comic) [last accessed on 2019.10.29]. 
transmedia storytelling experience, but actually, they do not expand the storyworld. ${ }^{187}$

On the other hand, one can learn more about the storyworld by the way how the plot, the protagonists, antagonists, and creatures are described, displayed, and designed. As already mentioned in chapter 3.2, adaptions are transmedia but do not expand the storyworld. Still an adaption can re-interpret and enrich a story. Every adaption that appears in a different media form requires specific design and reinterpretation of the narrative in new dimensions respective to the complexion of the output-media type. In case of comic books, narrative aspects that can only insufficiently be displayed in films or described in books can be plotted in detail inside a comic book, such as monsters, ghosts, or oversized objects and relations.

In case of The Witcher/Geralt Saga, two comic series exist. The first comic series was published between 1993 and 1995 in Poland and is a retelling of Andrzej Sapkowski's short stories. ${ }^{188}$ For this comic series, the same facts apply as for the previous example of Game of Thrones or The Hobbit. The second comic series of The Witcher is licensed by $C D$ Project, which is the developer of The Witcher computer game series and has been published from 2014 until now. This comic book series contains stories that expand the storyworld because they are neither part of the computer games nor of the novel series. ${ }^{189}$ So, in this case, it is not an adaption but rather an evident expansion in the proper sense of transmedia storytelling.

In conclusion, for most of the survey's examples, there exist only adaptions and retellings in the form of comics and graphic novels. Therefore, it is a specific conflict that most consumers of this media form have the intention to learn more about the storyworld. However, the consumer can learn more about the storyworld by consuming the plot in another design of narrative. It can also be included in a transmedia storytelling experience as a prequel or sequel of the core story. For a real storyworld expansion in the proper sense of transmedia storytelling, only the current comic book series of The Witcher is suitable to learn genuinely more about the own storyworld.

Films and TV series are one of three media types where the intention of learning more about the respective storyworld represents an amount of less than $80 \%$ with only $65.52 \%$ of all consumers and hence a more considerable amount of intention for watching an adaption with $30.05 \%$ of all consumers. ${ }^{190}$ For films and TV series, the correlation of retellings and storyworld expansions are more complex, especially in case of the survey examples. In case of big fantasy franchises, films and TV series are intentioned as adaptions of the beforehand published books, such as in the case of Harry Potter, The Lord of the Rings, The Hobbit, or Game of Thrones. The transition

187 A Wiki of Ice and Fire: A Game of Thrones (comics). A Wiki of Ice and Fire,2019. https://awoiaf. westeros.org/index.php/A_Game_of_Thrones_(comics) [last accessed on 2019.10.29].

188 Witcher Wiki: The Witcher Comics. Fandom, Fandom Inc. 2019. https://witcher.fandom.com/wiki/ The_Witcher_(comics) [last accessed on 2019.10.29].

189 Hexer Wiki: CD Projekts The Witcher franchise. Gamepedia, Fandom Inc., 2019. https://hexer. gamepedia.com/CD_Projekts_The_Witcher_franchise\#Comics [last accessed on 2019.10.29].

190 See Attachment A1. 
of a narrative from a book media type to a film media type is laborious because a new visual dimension, as well as an audio dimension, must be designed sufficiently to carry and annotate the story. Furthermore, emotions, inner conflicts, and thoughts need to be described and displayed by the embodiment of the actors or musical design. In contrast, a book can describe emotions and thoughts by inner monologues in form of text. One more point is the dynamic aspects of an audiovisual media type, such as the limitation of experience length and user participation.

A film, like one from The Hobbit trilogy, has a length of about two and a half hours and once started runs without the participation of the consumer - in contrast to a book, where the reading behavior determines how long it takes the consumer to consume the whole storyline. Furthermore, the consumer has to read the text to consume the story. In case of computer games, the consumer's participation is even more essential because the user has to control the protagonist to experience the story. The playing behavior of the consumer determines how much time is necessary to consume the story. Hence, it could take over 100 gaming hours or reading hours until a person has consumed the whole story. One could argue that a consumer could control the experience length of a film by watching the film over specific intervals. For example, they are watching each day 30 minutes of The Hobbit film and finish the whole film in a total of five days instead of 180 minutes. However, this argument is not practice-oriented and very uncommon.

On the other hand, it is a valid argument for TV series such as Game of Thrones. A single episode has a length of 50 to 70 minutes. The consumer must watch all episodes in chronological order to consume the whole story. Therefore, the consumer can control, depending on his or her watching behavior, how long it takes to finish the story. In this case, it is the same situation as for books and computer games. However, it also differs in the involvement of the consumer in active participationprocesses. For a film or series, the consumer only needs to push the play-button and pay attention to the film that runs without any further participation. For a book, the consumer must maintain the active process of reading and comprehending the text to consume a story. In the case of a computer game, the consumer must even control the protagonist, comprehend the gaming mechanics, and make decisions, which means he or she is highly involved in active processes to consume the story.

In conclusion, films and TV series require comprehensive design and implementation in different aspects and dimensions (e.g., moving images, sound design, and music) than for text- or print-based media types. Film and series also differ from computer games by the degree of consumer participation. Such aspects cause that retellings and adaptions of books in the form of films and series deliver a special re-experience of the same story. This aspect could be a proper explanation for the high amount of consumers whose intentions are the re-experience of the story by the film or TV series media. Nevertheless, designing additional dimensions of a story does not expand the storyworld by new narratives.

Films and series expand the storyworld when they tell new stories that take place beyond the books. For example, after the eight-part Harry Potter film series was finished in 2011, a new five-part film series called Fantastic Beasts emerged in 2016. This 
new film series is still current, and the plot plays inside the Harry Potter storyworld. The storyline of Fantastic Beasts takes place decades before the storyline of Harry Potter and addresses elements of the books, but does not base on a particular book that was published beforehand. As a consequence, the Fantastic Beasts series expand the storyworld of Harry Potter with new narratives.

The series and films of Game of Thrones and The Hobbit have expanded their respective storyworlds, too. Since season six, the plot of Game of Thrones is beyond the scope of the novel series storyline. Furthermore, Game of Thrones made some modifications to the original storyline of A Song of Ice and Fire. ${ }^{191,}{ }^{192}$ Hence, Game of Thrones expands its respective storyworld by a kind of prequel or extension and by an alternative storyline. The same applies to The Hobbit film-trilogy, which also contains extensions and modifications of the original book storyline.

This transfictional operations probably rely on dramaturgical decisions to address a broader target audience or because the whole storyline does not fit in a typical playtime of a film or series episode. Therefore, extensions and modifications to the original storyline would be necessary to edit the plot for the film or series output media.

All in all, films and series are a proper media type as well, to expand the respective storyworld, as examples like the Fantastic Beasts film series or Game of Thrones proves. However, due to the specific properties of this media type, more transfictional operations than an only straightforward prequel or sequel extensions appear, such as modifications and displacements. Such operations are the reason why films or series expand the storyworld by alternative stories next to the original stories.

Computer games have the most balanced distribution of all reasons why they have been chosen for further consumption. The most extensive share of possible reasons still represents the willingness to learn more about the respective storyworld with $54.45 \%$ of all consumers. $35.60 \%$ of all consumers wanted to re-experience the story, and $9.95 \%$ had other reasons, most to play a computer game, regardless of the storyworld..$^{193}$

Similar to films, computer games offer an audiovisual dimension for telling a story. Furthermore, computer games require a considerably high degree of participation and control from the user. Most current and famous computer games that contain a fantasy narrative, such as The Witcher series, The Elder Scrolls series, or the Souls series are classified as role-playing, adventure role-play, and open-world games. These classes of games seem to carry a suitable narrative. However, nearly all classes of games could include a narrative because, in practice, users, developers, and retailers classify computer games by gaming mechanics and not by narratological or literary aspects.

Nevertheless, the player must follow the course of the respective computer

191 See chapter 3.4. Transficitionality, page 25.

192 Game of Thrones Wiki: Unterschiede zwischen Buch und Serie. Fandom, Fandom Inc. https:// gameofthrones.fandom.com/de/wiki/Unterschiede_zwischen_Buch_und_Serie [last accessed on 2019.10.30].

193 See attachment A1. 
game to consume the story. As a result, the consumer must play the game actively, as well as a consumer of a printed book must read actively to experience the storyline. In contrast, a consumer of a film only must play the movie first and then pay attention to it. In this case, the degree of the user's participation and control is less than for computer games or print-books. Consequently, playing computer games requires a high amount of time and attention. Especially in examples such as The Witcher III - Wild Hunt, where the player needs about 40 game hours the consume the main storyline only and actually about 200 game hours to experience the main storyline with all side stories and quests. ${ }^{194}$

Furthermore, gaming can be costly compared with books, comics, or films. Most high-quality computer games cost around $40 €$ and $70 €$, depending on the currentness. As table 3 shows, the most printed books and DVDs of the survey's examples have a price starting from rounded $10 €$ to $20 €$ per media. ${ }^{195}$

Most computer games of the survey's examples expand the storyworld of the particular samples. For instance, The Witcher computer games series (2007 - 2016) tells a new story starting where the novel series ended. The Middle-Earth computer game series (2014 - 2017) tells a parallel story besides the storylines of The Lord of the Rings and The Hobbit. Lastly, the Game of Thrones - Tellgame series (2014) tells a parallel story of House Forrester next to the storylines of A Song of Ice and Fire and Game of Thrones. So, these computer games examples of fantasy franchises fulfill the proper sense of transmedia storytelling.

On the other hand, there are many computer game adaptions, but only for the example of Tolkien's Legendarium. These computer games retell the storylines of The Hobbit and The Lord of the Rings Trilogy. However, the number of computer games that expand the storyworld of Tolkien is considerably higher than the number of computer games that only retell storylines that have been already told on other media. ${ }^{196}$ The same situation applies to other examples of the survey. ${ }^{197}$, ${ }^{198}$ For other fantasy franchises, the ratio could alternate. In the case of the Harry Potter franchise, the number of computer games that retell the already existing storyline is higher than of computer games that expand the storyline. On the other hand, many computer games of the Harry Potter franchise are occasion games that do not contain an extensive storyline. ${ }^{199}$

In conclusion, it seems that computer games are a favored media type to expand the storyworld. However, many consumers use them to re-experience a story, too. One could consider that the high involvement by the degree of the user's participation

194 See fn. 194.

195 Prices on Amazon on 2019.11.02.

196 Wikipedia: Middle-Earth in video games. https://en.wikipedia.org/wiki/Middle-Earth_in_video_ games [last accessed on 2019.11.02].

197 Book Riot: AN EPIC LIST OF 29 GAME OF THRONES GAMES. https://bookriot.com/2019/06/05/ game-of-thrones-games/ [last accessed on 2019.11.02].

198 Wikipedia: The Witcher. https://en.wikipedia.org/wiki/The_Witcher [last accessed on 2019.11.02].

199 Wikipedia: Harry Potter video games. https://en.wikipedia.org/wiki/Harry_Potter_video_games [last accessed on 2019.11.02]. 
is the explanation of why computer games are attractive for adaptions as well for storyworld expansions. The fact that most computer games that carry a substantial fantasy narrative are role games could also deliver an explanation of why this media type is so seemingly favored for storyworld expansions and adaptions. The principle of role games is that the player takes over the role of a real or fictional character. Commonly, throughout the game, the player can design the character by its abilities or items.

So consequently, the player operates inside the storyworld with the help of a character that represents pieces of the player's personality. Such a circumstance brings a higher involvement because the player has the feeling of operating independently inside the storyline, instead of being a bystander only. Based on that situation, the excitement of the player can be maintained by a new storyline, instead of retelling a story, the player already knows. So it is conclusive that computer games, especially role play games, offer an occasion for the expansion of the storyworld.

\subsubsection{Interpretation and discussion in terms of the media type's potential}

This subchapter examines the number of interviewees that refused or have not yet managed to consume the media types examples of the survey. Furthermore, it puts up theses about the capability of some media types and how to increase the interest and consumption of the respective media types.

As the survey's results reveal, most people are still interested in watching the movies and series, or in reading the books of the particular example. In case of the book media type, $68.26 \%$ of all interviewees who have stated that they did not read a book of their chosen storyworld specified that they are still interested in doing so. ${ }^{200}$ A closer view of the example's distribution reveals that the ratio lies in a similar range for every example.

Tab. 6 Distribution for non-consumption of books.

\begin{tabular}{lrrr} 
& $\begin{array}{c}\text { Total non-con- } \\
\text { sumption for } \\
\text { books of this } \\
\text { storyworld }\end{array}$ & $\begin{array}{r}\text { Absolute frequency of } \\
\text { people that are still } \\
\text { interested in reading } \\
\text { the books of this } \\
\text { storyworld }\end{array}$ & $\begin{array}{r}\text { Relative frequency of } \\
\text { people that are still in- } \\
\text { terested in reading the } \\
\text { books of this storyworld }\end{array}$ \\
\hline $\begin{array}{l}\text { Tolkien's Legendar- } \\
\text { ium }\end{array}$ & 53 & 28 & $52.8 \%$ \\
\hline $\begin{array}{l}\text { A Song of Ice and Fire/ } \\
\text { Game of Thrones }\end{array}$ & 115 & 89 & $77.4 \%$ \\
\hline $\begin{array}{l}\text { The Witcher/ } \\
\text { Geralt Saga }\end{array}$ & 62 & 40 & $64.5 \%$
\end{tabular}

200 See attachment A1. 
For films and series, $89.58 \%$ of all interviewees who did not watch any movies or series of their chosen storyworld, are still interested in doing so. However, the distribution of this value is not equal.

Tab. 7 Distribution for non-consumption of films and series.

\begin{tabular}{lrrr} 
& $\begin{array}{r}\text { Total non-consump- } \\
\text { tion for watching } \\
\text { movies and series of } \\
\text { this storyworld }\end{array}$ & $\begin{array}{r}\text { Absolute frequency } \\
\text { of people that are } \\
\text { still interested in } \\
\text { watching } \\
\text { movies and series of } \\
\text { this storyworld }\end{array}$ & $\begin{array}{r}\text { Relative frequency } \\
\text { of people that are } \\
\text { still interested in } \\
\text { watching } \\
\text { movies and series of } \\
\text { this storyworld }\end{array}$ \\
\hline Tolkien's Legendarium & 0 & 0 & $0 \%$ \\
\hline $\begin{array}{l}\text { A Song of Ice and Fire/ } \\
\text { Game of Thrones }\end{array}$ & 2 & 1 & $50 \%$ \\
\hline $\begin{array}{l}\text { The Witcher/ } \\
\text { Geralt Saga }\end{array}$ & 96 & 85 & $88.54 \%$
\end{tabular}

The distribution reveals that every interviewee who has chosen Tolkien's storyworld also watched a film or series of this storyworld. For the storyworld of A Song of Ice and Fire/Game of Thrones, two interviewees did not watch Game of Thrones, and one is still interested in doing so. Most consumers of The Witcher storyworld however, did not watch any movie or series yet, but $88.54 \%$ of these consumers are still interested in doing so. So, The Witcher/ Geralt Saga represents nearly the whole amount of interviewees that did not watch a film or series of their chosen storyworld. The explanation for such a concentration in this scope of examination lies in the sales pitch of films and series for The Witcher or The Geralt Saga. Only one film (2001) and a following 13-part series (2002) that adapt the stories of the Geralt Saga were released until now. Besides, the film got a lot of bad reviews, which also affected the series. ${ }^{201}$

In contrast, the Legendarium of Tolkien has two successful film trilogies, where The Lord of The Rings is the seventh most successful worldwide. ${ }^{202}$ Game of Thrones was the third most favored series in Germany (2016), ${ }^{203}$ and the viewing figures have increased until 2019 and the final season. ${ }^{204}$ The weak offering of films and series for

201 Hexer Wiki: Der Hexer (Film). Fandom, Fandom Inc., 2019. https://hexer.gamepedia.com/ Der_Hexer_(Film) [last accessed on 2019.11.05].

202 Box Office Mojo: Ranking der nach Einspielergebnis erfolgreichsten Filmreihen und -franchises weltweit bis Juli 2019 (in Milliarden US-Dollar), Chart 16th June 2019. Statista, 2019. https://de. statista.com/statistik/daten/studie/932924/umfrage/erfolgreichste-filmreihen-undfranchisesnach-einspielergebnis/ [last accessed on 2019.10.14].

203 Statista: Ranking der beliebtesten Fernsehserien in Deutschland im Jahr 2016. Statista. Statista GmbH, 2016. https://de.statista.com/statistik/daten/studie/581038/umfrage/ranking-der-beliebtestenfernsehserien-in-deutschland/ [last accessed on 2019.11.05].

204 TV Series Finale: Anzahl der durchschnittlichen Zuschauer pro Staffel von Game of Thrones in den USA in den Jahren 2011 bis 2019 (in Millionen). Statista. Statista GmbH, 2019. https://de.statista.com/ statistik/daten/studie/990751/umfrage/zuschauerzahl-pro-staffel-von-game-of-thrones/ [last 
The Witcher or The Geralt Saga could be an explanation of why $53 \%$ of all interviewees who have chosen the storyworld of The Witcher, did not watch a film or movie of this storyworld yet. The high interest of these people could rely on the fact that Netflix will release a new series-adaption of The Geralt Saga in December 2019. ${ }^{205}$ However, films and series are the media form with the lowest number of total non-consumption, and approximately all of these belong to The Witcher. This situation could have its reason in the fact that for Tolkien's Legendarium or Game of Thrones, most people started with the movies or series to enter the storyworld. Therefore, the high capability does not belong to films and series in general, but rather in films and series that adapt the storyline of The Witcher/The Geralt Saga due to its lack of sales pitch for this media type.

For each remaining media type, the share of interviewees that are still interested in further consumption lies in a range between $24 \%$ and $29 \%$ relative to each media type's total of non-consumption. Websites and online wikis have the lowest number of non-consumption, and consequently, the least significant capability to bring more people to consume.

Tab. 8 Distribution for non-consumption of various media types.

\begin{tabular}{lrrr} 
& $\begin{array}{r}\text { Total non- } \\
\text { consumption for this } \\
\text { media form }\end{array}$ & $\begin{array}{r}\text { Absolute frequency } \\
\text { of people that are } \\
\text { still interested in } \\
\text { doing so }\end{array}$ & $\begin{array}{r}\text { Relative frequency } \\
\text { of people that are } \\
\text { still interested in } \\
\text { doing so }\end{array}$ \\
\hline $\begin{array}{l}\text { Websites and } \\
\text { online wikis }\end{array}$ & 134 & 33 & $24.67 \%$ \\
\hline $\begin{array}{l}\text { Comic books and } \\
\text { graphic novels }\end{array}$ & 583 & 154 & $26.15 \%$ \\
\hline Computer games & 315 & 89 & $28.25 \%$ \\
\hline $\begin{array}{l}\text { Merchandising } \\
\text { products }\end{array}$ & 273 & 73 & $26.74 \%$
\end{tabular}

In contrast, comic books and graphic novels, the media type with the highest number of non-consumption, have a more significant capability to bring more people to consume. Especially when one compares the absolute frequencies of these media types, it is clear that comic books and graphic novels have a more extensive capability in a commercial sense. The distribution of all examples applies in s similar range for the remaining media types, except for computer games.

The distribution of non-consumption frequency for computer games reveals that the non-consumption pertains to Tolkien's Legendarium and A Song of Ice and Fire/Game of Thrones only. Every interviewee that has chosen The Witcher/Geralt Saga has also played at least one computer game of this storyworld.

accessed on 2019.11.05].

205 The Witcher | Haupt-Trailer | Netflix (2019.10.31): YouTube Video added by Netflix Deutschland Östereich und Schweiz. Available at URL: https://www.youtube.com/watch?v=qAQutN0T2xI [last accessed on 2019.11.05]. 
Tab. 9 Distribution for non-consumption of computer games.

\begin{tabular}{lrrr} 
& $\begin{array}{r}\text { Total non-consump- } \\
\text { tion for computer } \\
\text { games of this } \\
\text { storyworld }\end{array}$ & $\begin{array}{r}\text { Absolute frequency } \\
\text { of people that are } \\
\text { still interested in } \\
\text { playing computer } \\
\text { games of this } \\
\text { storyworld }\end{array}$ & $\begin{array}{r}\text { Relative frequency } \\
\text { of people that are } \\
\text { still interested in } \\
\text { playing computer } \\
\text { games of this } \\
\text { storyworld }\end{array}$ \\
\hline Tolkien's Legendarium & 114 & 25 & $21.93 \%$ \\
\hline $\begin{array}{l}\text { A Song of Ice and Fire/ } \\
\text { Game of Thrones }\end{array}$ & 200 & 64 & $32.00 \%$ \\
\hline The Witcher/ & 1 & 0 & $00.00 \%$ \\
Geralt Saga & & &
\end{tabular}

The inspection of the absolute frequency reveals that the most significant capability for computer game consumption lies in A Song of Ice and Fire and Game of Thrones. In the case of The Witcher/Geralt Saga, all interviewed consumers have already played a computer game that belongs to this storyworld - likely because most consumers have chosen the computer games series as a mothership to enter the storyworld for the first time. Only one person from the interview did not play a game from The Witcher series because the person stated he or she watched a Let's Play ${ }^{206}$ of the games.

This capability relies just on the statement that the people have not yet managed to consume the particular media type and storyworld. However, there are more reasons why interviewees have not yet consumed a particular storyworld or media type. For instance, a considerable amount of consumers has refused further consumption of the storyworld because of the media type or the existing proposal.

The number of interviewees that have no further interest in consuming the chosen storyworld on a particular media type's proposal differs considerably from type to type. A reason why a person does not consume a storyworld by a specific media type's proposal could be the quality or design of the particular media product. For example, a person stated to dislike the writing style of J.R.R. Tolkien, and hence this person refuses any further consumption of this storyworld by the novel series. ${ }^{207}$ The same issue occurs in the case of the books of $A$ Song of Ice and Fire. ${ }^{208}$ Another person stated that the books of The Lord of the Rings are too large for reading. ${ }^{209}$ In the case of The Geralt Saga, a further person from the interview stated to dislike the design and production of the film, which was released in $2001 .{ }^{210}$ The essential factor of these explicit examples could also apply to other media types. For instance, a person dislikes the graphic design or gaming mechanics of a computer game or the drawing

206 Commented show of playing computer game.

207 See attachment A2.

208 See attachment A2.

209 See attachment A2.

210 See attachment A2. 
style of a comic, or the quality of a merchandise product. Such personal preferences for a particular media type could be a reason why a person refuses any further consumption of a storyworld. In conclusion, it is a refusal by design and quality of the particular media products and the general proposal of the particular media type.

Films, series, and books are the media forms with the lowest number of non-consumption that are based on this reason, with a relative frequency below $10 \%$.

In contrast, websites and online wikis are the media type with the highest number of non-consumption that is based on this reason, with a relative frequency of $44.48 \%$. However, websites and online wikis are also the media type, which has the highest number of further consumption and the highest number of consumers that want to learn more about the storyworld. ${ }^{211}$ Based on the absolute frequency merchandising products are the media type with the most extensive number of nonconsumption because of the insufficient proposal.

Tab. 10 People refuse the consumption of a media type due to a poorly offer.

\begin{tabular}{lrrr} 
& $\begin{array}{r}\text { Total non- } \\
\text { consumption for this } \\
\text { media type }\end{array}$ & $\begin{array}{r}\text { Absolute frequency } \\
\text { of people that refuse } \\
\text { the consumption of } \\
\text { this media type due } \\
\text { to a poorly offer }\end{array}$ & $\begin{array}{r}\text { Relative frequency } \\
\text { of people that refuse } \\
\text { the consumption of } \\
\text { this media type due } \\
\text { to a poorly offer }\end{array}$ \\
\hline $\begin{array}{l}\text { Websites and } \\
\text { online wikis }\end{array}$ & 134 & 60 & $44.78 \%$ \\
\hline $\begin{array}{l}\text { Merchandising } \\
\text { products }\end{array}$ & 273 & 77 & $28.21 \%$ \\
\hline Computer games & 315 & 70 & $22.22 \%$ \\
\hline $\begin{array}{l}\text { Comic books and } \\
\text { graphic novels }\end{array}$ & 583 & 75 & $12.73 \%$ \\
\hline Books & 230 & 19 & $8.26 \%$ \\
\hline Films and series & 98 & 3 & $3.06 \%$
\end{tabular}

A media agency, gaming development company, or publishing house could transform this share of consumption refusal into capability for further consumption by increasing the quality or changing the design of the media products. Especially for merchandising products, computer games, and comic books, a design that is close to the consumer's demand and proposals of high-quality products could encourage more people to consume a storyworld in the particular media form. These theses will be closer examined in chapter 6.2.

Another reason for non-consumption is the general refusal of a media type. For example, $51.27 \%$ of the total non-consumption for comic books and graphic novels represent people that refuse this media type in general, and regardless of the storyworld and the belonging proposals. 
Tab. 11 People that generally refuse the consumption.

\begin{tabular}{lrrr} 
& $\begin{array}{r}\text { Total non- } \\
\text { consumption for } \\
\text { this media type }\end{array}$ & $\begin{array}{r}\text { Absolute frequency of } \\
\text { people that refuse the } \\
\text { consumption of this } \\
\text { media type generally }\end{array}$ & $\begin{array}{r}\text { Relative frequency of } \\
\text { people that refuse the } \\
\text { consumption of this } \\
\text { media type generally }\end{array}$ \\
\hline $\begin{array}{l}\text { Comic books and } \\
\text { graphic novels }\end{array}$ & 583 & 302 & $51.27 \%$ \\
\hline $\begin{array}{l}\text { Merchandising } \\
\text { products }\end{array}$ & 273 & 113 & $41.39 \%$ \\
\hline Computer games & 315 & 130 & $41.27 \%$ \\
\hline $\begin{array}{l}\text { Websites and } \\
\text { online wikis }\end{array}$ & 134 & 34 & $25.37 \%$ \\
\hline Books & 230 & 33 & $14.35 \%$ \\
\hline Films and series & 98 & 3 & $3.06 \%$
\end{tabular}

Furthermore, the results reveal a significant number of people that also refuse computer games and merchandising products, with a relative frequency slightly above $41 \%$. Comparing the absolute frequency, comic books, and computer games have the most extensive number of general media type refusal.

In case of this reason, it could be challenging to encourage people to consume content of the generally refused media type. It might be possible, with a media product which expands the storyworld considerably, and which is available on one media type exclusively, to encourage such people to consume the particular media type. However, such encouragement is possible with extraordinary design, quality, substantial, and access components only.

For example, inside of a transmedia storytelling system, the storyline of an audience favored secondary character expands by a parallel story, which is only available on a graphic novel. In the mothership media, the storyline of this secondary character ends with a cliff hanger, ${ }^{212}$ and a large part of the audience wants to know more about the character's fate. As a result, many people from this audience group would consider buying this specific comic book, even if they are not generally interested in comic books. However, many people would also consider not buying this specific comic book and switch to online forums or online wikis to read about the character's fate and gaining information from the fan-community. So, except for the substantial and access components, it is advisable to add a unique design and quality component, too. The more product managers enrich such a proposal uniquely, the higher is the opportunity to encourage people to consume such a product, even if they refuse this kind of media type commonly.

Besides the interest and refusal, there are less significant reasons for nonconsumption, such as the interviewee is not able to consume a particular media type or scattered reasons that are summarized as "Other Reasons.” The option of being not able to consume a particular media relies on the approach that some people are 
physically disabled, or they have not the necessary hardware. This reason represents a range of relative frequency between $0 \%$ and $3.12 \%$ of total nonconsumption, for all media types from the survey. In case of merchandising products, this option of reason does not exist, because the proposal of merchandising products is so considerably vast and diverse, that such a reason has no significance. The most significant number of this reason appears in computer games, which is the only media type that could require the acquirement of a gaming console besides the game itself. Therefore, the possibility of missing hardware is considerably higher for computer games and, consequently, an explanation of the highest value for this reason. All in all, this reason is not considerable enough to start a broader examination.

However, a broader examination of the "Other Reason" summarization reveals a further cause cause the non-consumption of comic books that were not available in the survey. Other reasons represent a relative frequency of $9.17 \%$ for total non-consumption of comic books, and approximately $76 \%$ of these other reasons are the fact that people did not know about their existence inside of the transmedia storytelling system.

Tab. 12 Distribution of people that did not know about comic book proposals.

\begin{tabular}{|c|c|c|c|c|c|}
\hline Storyworld & $\begin{array}{l}\text { Total non- } \\
\text { consumption }\end{array}$ & $\begin{array}{r}\text { Absolute } \\
\text { frequency } \\
\text { of Other } \\
\text { Reasons }\end{array}$ & $\begin{array}{r}\text { Relative } \\
\text { frequency } \\
\text { of Other } \\
\text { Reasons }\end{array}$ & $\begin{array}{r}\text { Absolute } \\
\text { frequency of } \\
\text { people that did } \\
\text { not know about } \\
\text { the existence of } \\
\text { comic books for } \\
\text { this storyworld }\end{array}$ & $\begin{array}{r}\text { Relative } \\
\text { frequency of } \\
\text { people that } \\
\text { did not know } \\
\text { about the exis- } \\
\text { tence of comic } \\
\text { books for this } \\
\text { storyworld }\end{array}$ \\
\hline $\begin{array}{l}\text { Tolkien's } \\
\text { Legendarium }\end{array}$ & 226 & 26 & & 16 & $7.08 \%$ \\
\hline $\begin{array}{l}\text { A Song of } \\
\text { Ice and Fire/ } \\
\text { Game of } \\
\text { Thrones }\end{array}$ & 229 & 13 & & 11 & $4.80 \%$ \\
\hline $\begin{array}{l}\text { The Witcher/ } \\
\text { Geralt Saga }\end{array}$ & 134 & 15 & & 14 & $10.45 \%$ \\
\hline Total & 589 & 54 & $9.17 \%$ & 41 & $6.96 \%$ \\
\hline
\end{tabular}

Therefore, $6.96 \%$ of total non-consumption for comic books reasoned in the fact that the interviewee did not know about the proposal of comic books and graphic novels as part of the storyworld. Especially in the case of The Witcher, where graphic novels expand the storyworld with new interstitial microstories, 14 from a total of 181 (7.73\%) interviewees that have chosen The Witcher for the survey, did not know about its existence. When publishers could bring the proposal of such comic books to the interested public's attention, then more people might be encouraged to the consumption of this media type. 


\subsubsection{Interpretation and discussion in terms of further results and perceptions}

Besides the results of the target audience and consumption behavior, a few more perceptions and results from the survey and theoretical research emerged to be examined.

First, an extensive visualization of a story seems to build the basis for merchandising products. Such visualization must reach specific cultural approval and significance that relate to the success of the particular media product. For example, a massive proposal of merchandising products emerged of The Hobbit emerged with the film trilogy.

Second, for every media type's consumption except merchandising products, the most frequent reason is the willingness to learn more about the storyworld and the objects and creatures that are living in it. Just in the case of computer game consumption of $A$ Song of Ice and Fire/Game of Thrones, the most frequent reason is the re-experience of the same storyline (adaption). The study of the storyworld of $A$ Song of Ice and Fire/Game of Thrones storyworld gets an intense and complex fantasy structure and compared to the other storyworld examples, a small fantasy inventory (see chapter 5, figure 10, page 53). In four cases, the consumption reason to learn more about this storyworld exposes the least significant frequency, compared to the other examples. For films, series, websites, and online wikis, this reason is the most frequent in the case of $A$ Song of Ice and Fire/Game of Thrones.

Tab. 13 Distribution of people that want to learn more about the storyworld.

\begin{tabular}{lrrr} 
& Tolkien's Legendarium & $\begin{array}{r}\text { A Song of Ice and Fire } \\
\text { Game of Thrones }\end{array}$ & $\begin{array}{r}\text { The Geralt Saga } \\
\text { The Witcher }\end{array}$ \\
\hline Films and series & $63.95 \%$ & $71.88 \%$ & $64.71 \%$ \\
\hline Books & $79.05 \%$ & $75.26 \%$ & $92.23 \%$ \\
\hline Computer games & $55.38 \%$ & $36.96 \%$ & $100.00 \%$ \\
\hline $\begin{array}{l}\text { Comic books } \\
\text { Graphic novels }\end{array}$ & $91.67 \%$ & $64.71 \%$ & $82.98 \%$ \\
\hline $\begin{array}{l}\text { Websites } \\
\text { Online wikis }\end{array}$ & $88.10 \%$ & & \\
\hline $\begin{array}{l}\text { Merchandising } \\
\text { products }\end{array}$ & $10.45 \%$ & $89.66 \%$ & $86.67 \%$ \\
\hline
\end{tabular}

The reason why Game of Thrones has the highest share of people that want to learn more through the series could rely on the fact that Game of Thrones continues the storyline of the still-unfinished novel series and unveils the final fate of the characters. The same situation on websites and online wikis could be explained by the firm and complex fantasy structure. In A Story of Ice and Fire/Game of Thrones, multiple heroes appear and experience their storyline in a vast and complex imaginary social 
system along with different timelines. Furthermore, the stories inside this transmedia storytelling system often tell about politics and schemings. Therefore, many relations and events between various imaginary characters, institutions, and creatures emerge and manifest the strong fantasy structure. Consequently, more consumers could go back to the websites and online wikis to look up such relations, timelines, and events of the storyworld.

The result of why this storyworld has the smallest share of people that want to learn more trough computer games could rely on the circumstance that the proposal of computer games is built out insufficiently, compared to the other examples. Only the Game of Thrones tell-game stories expand the storyworld. However, these computer games trail to the computer games of The Witcher and Tolkien's Legendarium regarding quality and recognition.

Furthermore, the fantasy inventory could affect the consumer's willingness to learn more about the particular storyworld. A storyworld with a high number of imaginary creatures and objects has a more significant scope for information and content than a storyworld with a lower number of imaginary creatures and objects. For instance, the orcs in Middle-Earth raise questions about their creation, culture, relation to other tribes, relations among themselves, and their history and future. Such imaginary entities produce much information that a consumer can learn about because it is imaginary and not known to a person from the primary world. Besides this, it enriches the secondary world with more information and content aspects that lead to further potential stories that could cause more media products. This thesis still needs to get a closer examination, whether consumers prefer storyworlds with a vast fantasy inventory to learn more from it. Such an examination could be realized through a further survey that goes deeper into the content of the examples.

Third, as the statistics in chapter four and the examples reveal, fantasy media products might be more successful in the form of a set of the same media type. It seems trivial because the basis of a transmedia storytelling system is a storyworld that is too big to be represented in only one media implementation. However, samples from real-life show that a series of one media type often built a canonic core storyline inside a storyworld that often achieves commercial success. For example, Game of Thrones, The Harry Potter film series, and also their particular novel basis, are a uniform set of the same media type. Such series provides a vast canonic story, which achieves massive commercial success and function as a mothership inside a transmedia storytelling system. Besides the fact that a series of the same media type can carry a vast and complex storyline sufficiently, the same media type also ensures the same consumption condition for every episode. For example, the shift from film to computer game requires the availability of hardware that can run computer games. This shift could cause a loss of consumers that do not have such hardware. Therefore, a media series should finish a storyline sufficiently and should not shift the media type in the telling of a story. However, such a shift happened in the case of Game of Thrones and the A Song of Ice and Fire novel series. The novel series is still unfinished, and so is the storyline. Game of Thrones tells an alternative story based on the events from the novels, also expanding, and even finishing the storyline. This 
shift from book to film and TV series or vice versa might cause less loss of consumers because a TV and books are a more regular part of the accessory. A Statista statistic reveals that $94 \%$ of all German households own a television receiver, $80 \%$ own a Laptop, $58 \%$ own a DVD or Bluray player, $55 \%$ own a PC, and $41 \%$ own a gaming console, all in 2018. ${ }^{213}$ Based on this data, it is plausible that a shift from book or TV to computer games could cause a more significant loss of consumers than a shift from book to film or vice versa.

\subsection{Strategic Theses for Publishing Houses and Media Agencies}

This subchapter creates theories of advisable strategies for publishing houses and media agencies. The aim is to create guidance about the creation, maintenance, and usage of a transmedia storytelling system. All following considerations are exemplary for publishing houses and content from the fantasy genre. Although most of the guidelines are also assignable to other media companies and content genres.

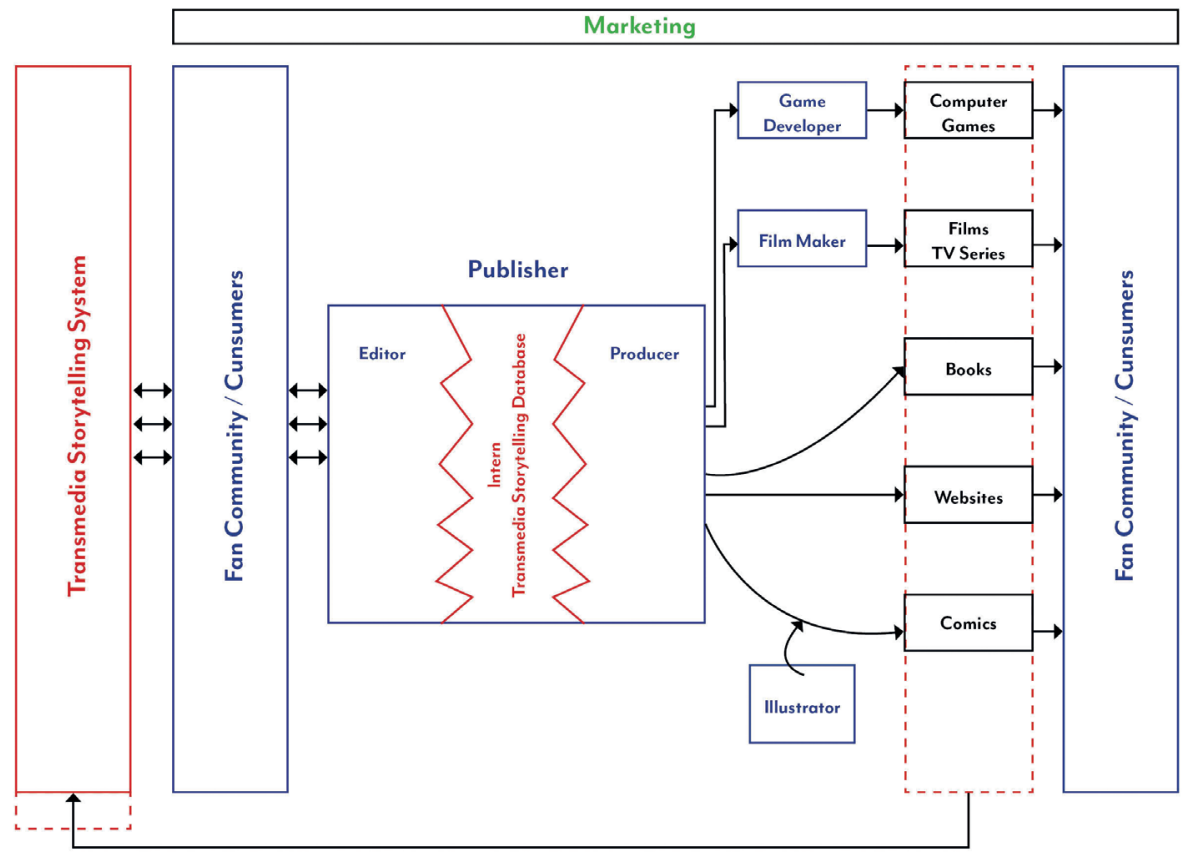

Figure 17 Example business model.

213 Statista: Welche der folgenden Geräte besitzen Sie in Ihrem Haushalt?, Statista, Statista GmbH, 2018. https://de.statista.com/statistik/daten/studie/476429/umfrage/geraetebesitz-fuer-denmedienkonsum-im-haushalt-in-deutschland/ [last accessed on 2019.11.08]. 
An exemplary business model is the basis of the following guidelines. The business model reveals two sides, a conception side handled by the publisher's editors and a production side handled by several producers. In the middle of the model lies a set of content, which is the object of publication and storyworld extension.

The exemplary business model pictures a circle of how a publisher or media-producer and the fan community expand a transmedia storytelling system and also utilizing its canonic documents. The editors of a publishing house adopt or develop a transmedia storytelling system and stay in contact with the particular fan community. Two kinds of information about the transmedia storytelling systems exist - first, the public system that is available and adjustable for every consumer or fan. Second, the intern database and information pool of the particular storyworld, which is only available to the publisher. The editors acquire and edit the content, and the producer edit and controls the further production of the content into new media assets. After production, these new media products expand the storyworld, and consequently, the entire transmedia storytelling system. Then the circle repeats, with an evolved storyworld. Marketing management affects the complete circle and should apply in every step of production and conception. The guidelines for the conception and editor side of the circle are presented first.

\subsubsection{Acquiring the right content}

A transmedia storytelling system can gain cultural recognition independently, or it could be developed by a company. The examined examples show that this is not an "either-or"-situation rather than it is lying in between both poles of ermergence. A storyworld gains a specific degree of cultural recognition by an audience with particular interest until a media company decides to adopt this storyworld and increase its popularity.

- So, in that sense, it is advisable to monitor the market for a transmedia storytelling system with the potential to gain popularity and commercial success.

In some technical forums, such as the publisher's forum 2017 in Berlin, experts considered, to hire editors that examines the market and creates the "new Harry Potter" and as a result, establishing a long-term transmedia storytelling system on their own - in conclusion, developing instead of monitoring as a strategy. However, a group of editors brings the risk of discord and consequently causing inconsistency in the storyworld. Inconsistency is a factor that is incompatible with a functioning storyworld and secondary world. The survey from this master thesis also revealed that an inconsistent and pedestrian writing style could lead to consumption refusal. The example of The Witcher displays a more suitable way of creating a transmedia storytelling franchise by involving editors and the original auhtor. Andrzej Sapkowski created a core of canonic stories that contains massive substantial depth and consistency. Based on these stories, $C D$ Project created a sequel with the help of other authors and editors in the form of computer games and comic books. It is 
undoubtedly possible to create a core of canonic stories by hiring a group of editors or a single talented author, but it is an additional factor of cost to create a story, instead of licensing a story and enlist the author in the profit. Besides, it is still not safe, that the storyworld gains commercial success.

- In conclusion, it is advisable to incorporate a core of canonic stories created by an author and to pitch and expand this storyworld with the help of a team of editors and other authors.

This perception raises the questions of how to search for a good story and how to pitch such a story. In current times, it is easier than ever to get in touch with groups of particular interest, such as fantasy enthusiasts, by using web forums, conventions, social media, and factors of globalization. As a company that aims to build a transmedia storytelling system and keep a long-term focus on it, it could be obligatory to stay in contact with such communities because these are one of the most critical target audiences for such storytelling franchises. Therefore the examination of such communities is mandatory to obtain the costumer's point of view, customer value, and wishes. Besides the opportunity to recognize new potential content and to gain essential marketing information, such groups also edit or expand the storytelling system by fanfiction and additional information.

- In conclusion, it is advisable to monitor communities of fantasy enthusiasts to gain information about new content, customer's point of view, -value, and -wishes, and lastly, about apocryphal stories, such as fanfictions.

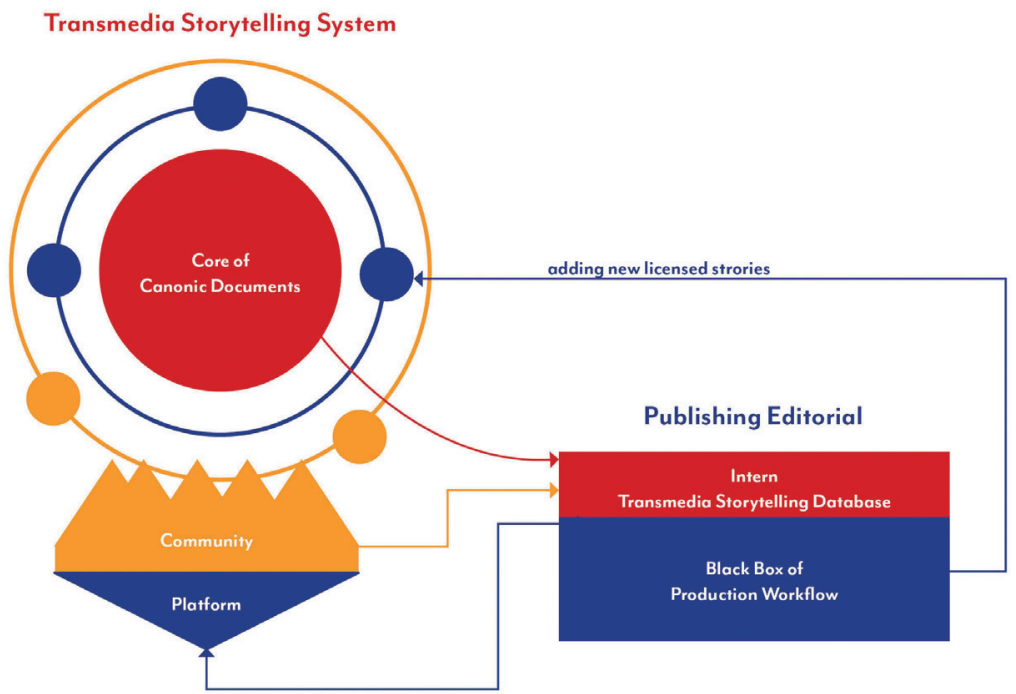

Figure 18 Example business model - editorial side. 
- Furthermore, it is judicious to establish and manage a platform for such communities. So the publisher can maintain bidirectional communication with its target audience, establish a long-term relation, gaining essential information, and build a positive image.

The exemplary business model also displays a bidirectional communication between the publisher and the fan community. Such a long-term relationship could build a positive image, a credit of trust, a channel for feedback and information of the costumer's wishes, and an opportunity to discover new content. All in all, it could help to create a trademark.

Furthermore, the survey reveals that several people did not know about a comic book proposal of the exemplary storyworlds. Such a community platform could help to advertise every media of this storyworld and deliver the entire amount of information to the audience and customers.

Another point is that the publisher can get in touch with user-generated content. After checking and validating this kind of content, the publisher should consider making use of it. Such content could bring new media products, a storyworld extension with commercial significance, and create customer loyalty.

- It could be profitable to incorporate content and ideas from the audience and consumers.

For proving this theory, it is advisable to interview people from the target audience what do they think about such content regarding quality, consistency, and image after they compared user-generated and author/editor-generated content.

\subsubsection{How to design a transmedia storytelling system?}

When a publisher finds a potential storyworld and a beginning of a transmedia storytelling system, it could be essential to know how to pitch a story for expanding and editing the storyworld. Marie-Laure Ryan and Henry Jenkins elucidate three components for designing a transmedia storytelling system. These components are

- Development of a storyline,

- Development of a character,

- Development of an entire world. ${ }^{214}$

All components depend on each out because a storyworld cannot develop its identity without characters that living inside of this world, and the characters cannot develop their identity without an associated personal story. ${ }^{215}$

214 Jenkins, Henry: Convergence culture - Where old and new media collide (New York: New York University Press, 2006) page 116 et seq.

215 Ryan, Marie-Laure: “Transmediales Erzählen im Zeitalter der Medienkonvergenz”, In: “Medien. 
Examples narratives that only focus on the plot are fairy-tales, such as Cinderella or Hansel and Gretel. Such characters do not have an individual personality that reaches beyond the events of the storyline. The same case applies to tragedies, which are driven by destructive actions, not individual personalities. ${ }^{216}$

Developing a character means to create a fictional person that seems to have an independent existence. It should induce the recipient's empathy for this fictional person.

Examples of personality focused narratives are Sherlock Holmes or James Bond. More usually, the personal progress of such fictional persons ceases over continuous storytelling because the narratives tend to follow the same structure from episode to episode. These fictional people became a kind of superhero that always solve all problems in every episode. In conclusion, the storyworld expands with every episode, but there is no essential alteration. ${ }^{217}$

Developing an entire storyworld means to establish a network of fictional people, where everyone has his/her personal story. These fictional people are related to each other. Depending on a personal storyline, some characters become protagonists while the other ones stay minor characters. These roles shift with another storyline. Such a dynamic relation between fictional characters and their particular storylines pitches an entire storyworld..$^{218}$

Furthermore, the storyworld must have changeless properties that work as a frame of reference for every storyline and character. Besides, the storyworld also should have a specific degree of diversity and complexity, which means that it needs content-related depths - for example, a massive number of details and diverse aspects. The storyworld should have an encyclopedic capacity of details, diverse aspects, relations, folklore, and many more. ${ }^{219}$

A flagship-examples of a storyworld focused narrative is G.R.R. Martin's novel series A Song of Ice and Fire, where multiple fictional persons, who are related to each other, endure their personal story. The world of Westeros and Essos is the same for every character (changeless frame of reference) and a massive amount of details, fictional cultures, history, geography, flora, and fauna.

- In conclusion, the design and development of fictional personalities with their particular personal story is the basis for the advancement and design of an entire world.

Erzählen. Gesellschaft” (De Gruyter: Berlin, 2013) page 111.

216 Aristoteles: Poetik (Stuttgart: Reclam, 1994) page 19.

217 Ryan, Marie-Laure: “Transmediales Erzählen im Zeitalter der Medienkonvergenz”, In: “Medien. Erzählen. Gesellschaft” (De Gruyter: Berlin, 2013) page 112 et seq.

218 See fn. 57.

219 Jenkins, Henry: Convergence culture - Where old and new media collide (New York: New York University Press, 2006) page 118 et seq. 
- The storyworld must have changeless properties, a massive degree of diversity and complexity, and contain a network of fictional personalities that relates to each other.

- According to the character's point of view, the roles of protagonists, antagonists, and minor characters determine dynamically and changeable.

- The fictional characters and their personal stories and relations to each other, filling the storyworld, which is predefined in detail by static and dynamic components with encyclopedic capacity.

The diversity and complexity of a storyworld should give rise to the same passion that brings people to studying historical maps or family histories. In the case of a transmedia storyworld, the audience should get encouraged to studying the particular fictional ethnic group, or the storyworld's history, or disclose a secret from the storyworld. The analysis of the survey also results that most recipients of fantasy franchises want to learn more about the storyworld.

- Therefore, it could be essential to provide enough diverse and complex content across several media types and in various episodes because the results reveal that most recipients are willing to learn more about the storyworld.

For proving this theory, it could be advisable to examine if a customer's demand for more complex content to learn more about remains or appears when there is no current supply from the publisher.

All in all, this master thesis underpins the factor that people are willing to consume from a transmedia storytelling system of fantasy content. Especially in consuming storyworld advancement by the motivation to learn about this world.

\subsubsection{After obtaining the right stories}

After a publisher found a suitable storyworld for processing, it is the next step to gain the legal right to use and further processing. As every expert should new is not possible to gain the copyright of the story because it only pertains to its creator. So, the publisher can only obtain the primary and secondary publication rights for a narrative. These rights should involve the processing and publications of all media types that are planned to be published.

- Therefore it is essential to consider beforehand how many different media types and output channels are required for publication.

The more rights a publisher want to gain, the higher are the fees that the creator can require. Besides this, it is also essential to consider to obtain exclusive rights or general rights. Obtaining exclusive rights prevent that another publisher builds up a transmedia storytelling system around the same storyworld. Besides, it is also essential to consider merchandising and cross-marketing measures, which require licensing, 
cooperating, and possibly outsourcing arrangements. As mentioned in the previous subchapter, the storyworld should reveal a massive amount of diverse and complex aspects, a network of fictional personalities that are related to each other, and the particular personal stories, besides changeless properties. Such a vast amount of information requires a management system to retain the overview and control of the content.

For aiming an advancement of the storyworld in the form of new spin-offs and for establishing data retention for the production, it is advisable to gather, save and display metadata, such as attributes and elements from the storyworld. Furthermore, it is advisable to create a characterization of every significant character of the storyworld. Such a characterization aims to gather all attributes from a fictional personality and enables them to comprehend the deeds and development of this person. Besides, it is a method to build a basis from where an editor or author can continue an authentic story that is consistent with the storyworld. Also, a visualization of the narrative's course could help an editor to keep an overview of such a massive amount of information.

- In conclusion, gathering meta and descriptive data from the storyworld, as well as visualizing the course of narratives and creating characterizations for significant fictional personality, could be proper methods for retaining consistency and create authentic extensions.

After entering the data from the storyworld into a management system and database, the rehashed content is ready for production. With every storyworld extension, such as parallel stories, new detailed information about objects and creatures from the author, or peripheral stories, the database needs to be updated with such information. A publisher could realize such a system with the help of already developed content management systems. On further research, it would be advisable to define requirements for a system that could help to manage the total data from a transmedia storytelling system - then followed by a series of tests with various content management systems to make a more precise point about requirements for the system and a selection of suitable supplier.

For the product conception, it could help to distinct into storytelling-products, describing-products, and representing-products. Storytelling products contain a complete story or a part of a bigger story that can stand alone and deliver satisfactory entertainment experiences, such as books or films. In contrast, describingproducts contains information, descriptions, or just metadata of characters, events, or relationships from the storyworld. They are not suitable to contain more than short peripheral stories, much less than a vast and complete story. Such describing-products could be entries on online wikis or card- and broad games. Representingproducts are items that represent the storyworld, such as merchandising or advertising products. They do not describe the storyworld or tells a story from it, but rather gain attention for the franchise. Also, the results of the survey revealed that in the case of websites, online wikis, and merchandise, no one wants to 
re-experience a mothership's story but instead of learning more about the storyworld or other reasons.

The results of the survey also revealed that for some media types, an extensive capability exists to gain a wider audience and more customers. After a transmedia storytelling system is once established and gains commercial success, it could be advisable to utilize the capability of new and less popular media types, such as comic books and computer games. For instance, exclusive continuations of storylines could encourage customers to consume such media types. Even waiting could be a proper strategy to make a product of an unpopular media type to a good seller - for example, a computer game with a particular storyline could achieve popularity in a long time, when since the release date the storyworld gains so much cultural recognition and customer's loyalty that fans consume the computer later. So, in that sense, it could be advisable to retain the proposal of the computer game, even when it is not a good seller for the first time.

Furthermore, every media types contain specific attributes that can help to pitch a character or even the storyworld. In the case of computer games, the degree of the recipients' participation is considerably high. The player controls the protagonist, and evolves his/her skills and also makes choices for his/her. The publisher could utilize these involvement properties of computer games to develop a personal story of a character close to the player's attention and empathy.

- In conclusion, the publisher should activate and utilize the potential of less popular media types, depending on commercial success after establishing the transmedia storytelling system and publishing the motherships of the storyworld.

Long-Term monitoring of such measures could provide more significant statements of whether less popular media types contain the capability for huge commercial success.

For establishing a transmedia storytelling system, it could be advantageous to implement the motherships of the storyworld in a medium with a low degree of recipient's participation and production effort. As already examined, a computer game or printed book requires a higher degree of the recipient's participation than a movie or wiki entry. On the other hand, a printed book requires less production effort than a high-quality movie or computer game. Besides, the access-factor to particular media affects consumption too - for example, a book-type media is more accessible than a computer game that requires specific hardware for consumption.

The results of the survey revealed that the three most consumed media are websites and online wikis, book-type media, films, and series, excluding merchandising products.

- As a result, it could be advantageous to publish the central narratives of the transmedia storytelling system in a media form that is easily accessible and requires a low degree of recipient's participation. 
The production effort is an intern factor that affects the company, besides the recipient's participation and consumption access are extern factors that affect the customer directly. However, the production effort determines the quality and design of the end product. Therefore it also affects the consumer, but rather as an indirect factor after with minor priority. The quality and design of the end product is instead an essential factor for the competition between products of the same media type. In contrast, the consumption access and participation degree are significant factors for the competition of different media types.

For further research, it would be helpful to establish a uniform system or model that displays the different levels of the participation degree, consumption access, and production effort for each significant media type. Such a system could support the publisher to make a more precise assessment of sales.

\subsubsection{The right publishing system}

On the production side of the business model, the focus of the examination moves to the publishing system. The publishing of multiple media in different forms require a multiple channel publication workflow. Based on this fact, the publisher has the choice to set up multiple media-specific source data for each output channel or to set up a single source data, which requires media impartial data retention. In other words, the publisher has the choice between a multiple-source-multiplechannel publication workflow (MSMC) or a single-source-multiple-channel publication workflow (SSMC). The advantage of an MSMC workflow is that a publisher is immediately ready to start the process. In contrast, an SSMC workflow requires the creation of media-impartial data retention, which means an extensive preparation and structuralizing of data before the publisher can start publishing. The advantage of an SSMC workflow is that it enables automatization and, consequently, savings on further processing. Also, corrections and modifications that appear in the ongoing publishing process can be globally implemented for every output channel with single editing in the source data. In contrast, an MSMC workflow allows no automatization, requires multiple and parallel processes; consequently, more personal resources and corrections must be implemented for each output channel manually. Furthermore, multiple parallel processes for multiple output channels contain the risk of content-related inconsistency.

- From there, a comprehensive cross-media publishing system with a singlesource-multiple-channel publishing workflow is highly recommended for working inside transmedia storytelling systems. 


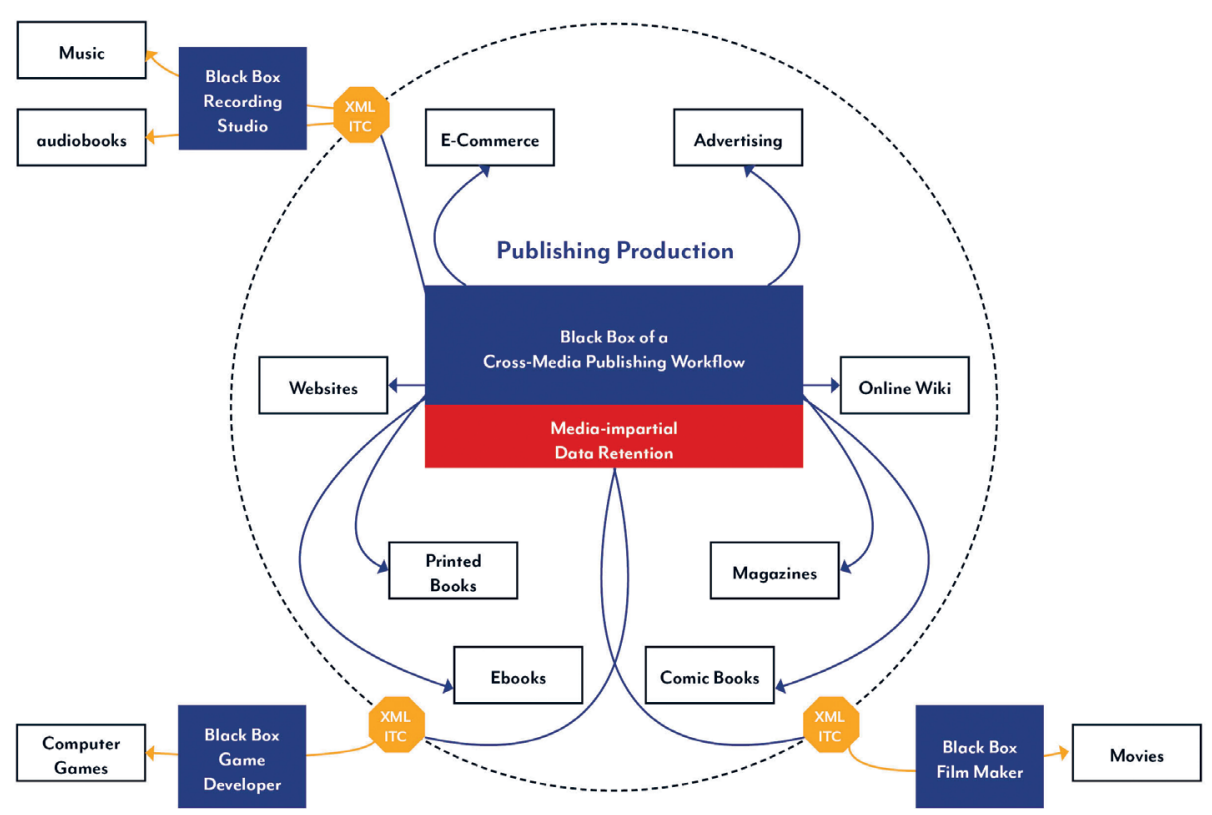

Figure 19 Example business model - production side.

A further point of production is considering the number of output media types. Mostly, every media type has its particular necessary creation process, which depends on its nature. Mostly each significant media type establishes its particular area of expertise and technology. Therefore a standard publisher cannot realize all media forms alone and need help from a specific partner, such as a film maker, a recording studio, or a game developer. As figure 17 shows, the publisher has a specific range of products that he/she could produce on its own. Most publishers cannot produce high-quality movies or computer games because they do not have the technology and skills. From there, they must team up with other companies.

- Publishing houses should consider cooperating with other media companies, that can produce media, for which the publishing house has not the skills and technologies

It also could be possible that a big umbrella media company contains several subsidiary companies or departments which could produce every possible media inside a uniform company setting. Walt Disney Studios or Marvel Entertainment are such companies, for instance.

For standard publishing houses, it is necessary to strike up cooperations with other media companies. 
- For cooperation, the partners should negotiate about the duration of working together, communication interfaces, uniform project management methods, and arrange interchange formats.

- It is advisable to use already existing interchange formats for unsteady production cooperations. In contrast, for steady production cooperations, it is advisable to create a process- aligned interchange format.

For most media types, particular XML-based interchange formats already exist - for example, XGF for computer games, ${ }^{220}$ MusicXML for sheet music, or development-specific XML files for further processing in Java. For movies and TV series, the literary form of the narrative must be transformed into a movie script. Most interchange formats facilitate the production of movies, recordings or computer games, but an automatization is not possible because of a considerable number of human resource processes, such as acting or programming, do not allow automation.

Also, merchandising requires to work with other companies, such as printing service hosts or craft enterprises. After cooperation succeeded and the companyacross operating cycles works smoothly, the publishing house could consider establishing a long-term partnership and cross-marting strategy schedule with the partner company about further productions inside the transmedia storytelling systems.

\subsection{In conclusion}

The progressive media convergence and the emergence of new media types and forms revived the trend of transmedia storytelling. A transmedia storytelling system can appear in various structures, of various reasons, and in concetn of multiple media content. However, the most popular transmedia storytelling structure exposes itself to new successful franchises, such as Game of Thrones, Harry Potter, or The Witcher. All these examples belong to the fantasy genre, and that for good reasons. The structure of the fantasy genre matches the structure of transmedia storytelling on significant points, such as the secondary world match with the storyworld, the fantasy structure match with the requirement of story development, and the fantasy inventory correspond with the required diversity and complexity of a storyworld.

Transmedia storytelling could create long-term customer's loyalty by the return of invested cognitive effort. In other words, when a recipient spent much time exploring a storyworld, he/she will steadily return to the storyworld to justify the invest of his/her cognitive effort. Furthermore, a transmedia storytelling system can establish communities and enables a flexible expenditure of time. The recipient can manage by his/her own, how in what period of time he/she consumes the components of the storyworld.

The survey of this master thesis revealed that most people are willing to learn about the storyworld and invest the cognitive effort for this. Most people who have not yet managed to consume all proposals of a transmedia storytelling franchise are

220 red-bean: XGF - An XML Game Format, https://www.red-bean.com/sgf/xml/ [last accessed on 2019.11.15]. 
still interested in doing so. This fact implies that such a transmedia storytellings system is a long-term project and could have a long life cycle. Furthermore, the results picture an arrangement of the media type's popularity and suitability concerning transmedia consumption. Book-type media, movies/TV series, websites, and merchandising are the most popular media in that sense. In contrast, computer games and comic books are less popular but contain a considerable capability for designing a transmedia storytelling system.

The editors and authors of a transmedia storytelling system should communicate with the fancommunity of the storyworld and steadily develop and expand the system to generate new products. By a specific degree of cultural recognition, a transmedia storytelling system could evolve into a commercial entertainment megatrend.

On the other hand, a transmedia storytelling system requires the processing of a massive amount of information, content and source data, obligatory inner consistency, bidirectional communication with the audience, and a sophisticated publishing and production business system, across multiple companies, departments or subsidiary companies. The setup, maintenance, and management of such systems require massive resources of staff, time, and finance.

A cross-media publishing system enables a specific degree of automatization and saving of resources. Besides, an SSMP workflow ensures the consistency of content for multiple output channels. A partnership with other media-production companies enables cross-marketing measures, which could cause better sales, and reduce resources of time and finance. It is advisable for publishing houses to create an imprint that focuses on the transmedia storytelling system only.

All in all, transmedia storytelling could be a long-term business strategy for the media industry. It requires massive investments recourses, a comprehensive marketing strategy to gain an audience, and the setup of sophisticated publishing and management system. However, once the transmedia storytelling system is established and adopted by the audience, it ensures long-term projects, sales, and resilience in competition. 


\section{Bibliography}

Aristoteles: Poetik (Stuttgart: Reclam, 1994).

Borden, Neil H.: The Concept of the Marketing-Mix. In: Science in Marketing (New York: John Wiley, 1964).

Bruhn, Manfred: Was ist eine Marke? Aktualisierung einer Markendefinition (Gräfeling: Gesellschaft zur Erforschung des Markenwesens e.V., 2002).

Bühler, Peter; Schlaich, Patrick; and Sinner, Dominick: Crossmedia Publishing | Single Source XML - Web-to-Print (Berlin: Springer Nature, 2019).

Carter, Lin: Imaginary Worlds - The art of Fantasy (New York: Ballantine Books, 1973).

Clute, John; Grant, John: The Encyclopedia of Fantasy (New York: St. Martins Press, 1997).

Doležel, Lubomír: Heterocosmica: Fiction and Possible Worlds (Baltimore: John Hopkins University Press , 1998).

Dombrowski, Caroline; Kim, Jeffrey; Lee Elan/Thomas Timothy: "Storytelling in new media: The case of alternate reality games, In: First Monday" Vol. 14, No. 6 (Illinois: University of Illinois, 2009).

Domizflaff, Hans: Die Gewinnung des Vertrauens (Hamburg: Marketing Journal, 1982).The case of alternate reality games, In: First Monday” Vol. 14, No. 6 (Illinois: University of Illinois, 2009).

Drucker, Peter: The Practice of Management (Düsseldorf: Econ, 1954).

Eddings, David; Eddings, Leigh: Der Riva-Kodex. Bergisch-Gladbach: Bastei Lübbe, 2000).

Fritzsche, Hans P.: Cross Media Publishing: Konzepte, Grundlagen und Praxis (Bonn: Galileo Press $\mathrm{GmbH}, 2001)$.

Heldmaier, Christian: Merchandising für Bücher ohne Filmanbindung. Grundlagen, Chancen und Umsetzungensmöglichkeiten für Verlage. Thesis (Stuttgart: Hochschule der Medien, 2011).

Huse, Ulrich: Verlagsmarketing (Frankfurt am Main: Bramann, 2017).

Jakubetz, Christian; Langer, Ulrike: Universalcode Journalismus im digitalen Zeitalter (München: euryclia, 2011).

Jenderek, Bastian: Fantasy und Realität - Eine empirische Untersuchung zur Wirkung des Genre Fantasy (Hamburg: tredition $\mathrm{GmbH}, 2009$ ).

Jenkins, Henry: Convergence culture - Where old and new media collide (New York: New York University Press, 2006).

Klastrup, Lisbeth/Tosca, Susana: “Transmedial Worlds - Rethinking Cyberworld Design”, In: Center for Computer Games Research (Copenhagen: IT University of Copenhagen, 2014).

La Blanc, Thomas: Was ist eigentlich Fantasy? In: Tolkien Times (Stuttgart: Klett-Cotta, 2003).

Meffert, Heribert: Marketing. Grundlagen marktorientierter Unternehmensführung. Konzepte Instrumente - Praxisbeispiele (Wiebaden: Gabler, 2000).

Meyer, Urs/Simanowski, Roberto/Zeller, Christoph: Transmedialität. Zur Ästhetik paraliterarischer Verfahren (Göttingen: Wallstein, 2006).

Noriaki, Kano, N. Seraku, F. Takahashi, S. Tsuji: Attractive Quality and Must-be Quality. In: Journal of the Japanese Society for Quality Control. (Wuhan: Scientific Research Publishing, 1984).

Pesch, Helmut: Fantasy - Theorie und Geschichte einer literarischen Gattung (Passau: Erster Deutscher Fantasy Club e.V., 2001).

Rowling; Joanne K.: Harry Potter and the Order of the Phoenix, Chapter 37 - The Lost Prophecy (London: Bloomsbury, 2003). 
Rühling, Lutz: Vorraussetzungen und Grundlagen der Literaturwissenschaft, In: Grundzüge der Literatur Wissenschaft (Munich: DTV, 1997).

Ryan, Marie-Laure: “Transmediales Erzählen im Zeitalter der Medienkonvergenz”, In: “Medien. Erzählen. Gesellschaft” (De Gruyter: Berlin, 2013).

Ryan, Marie-Laure: “Transmedia narratology and transmedia storytelling”, In: Artnodes no. 18 (Barcelona: Universitat Oberta de Catalunya, 2016).

Saint-Gelais, Richard: “Transfictionality”, In: Routledge Encyclopedia of Narrative Theory (London: Routledge, 2005).

Schilken, Dörthe: Die teleologische Reise von der christlichen Pilgerallegorie zu den Gegenwelten der Fantasy-Literatur. (Würzburg: Könighausen und Neumann, 2002).

Scolari, Carlos Alberto: Transmedia Storytelling: Implicit Consumers, Narrative Worlds, and Branding in Contemporary Media Production, In: International Journal of Communication 3 (Barcelona: University of Catalunya, 2009).

Tolkien, John Ronald Reuel: On Fairy-Stories, In: Gute Drachen sind rar. (Stuttgart: Klett-Cota, 1984).

Von Lucius, Wulf D.: Verlagswirtschaft (Konstanz: UVK Verlagsgesellschaft mbH, 2007).

Waggoner,Diana: The Hills of Faraway (New York: Atheneum, 1978).

Weinreich, Frank: Fantasy - Einführung (Essen: Oldib Verlag Oliver Bidlo, 2007).

Wirtz, Bernd W.: Medien und Internetmanagement (Wiesbaden: Gabler, 2009).

Wolff, Kurt: Autoren/Bücher/Abenteuer. Beobachtungen und Erinnerungen eines Verleger (Berlin: Wagenbach, 1965). 


\section{Source materials}

Albert Bauer Companies: Crossmedia Marketing. Albert Bauer Companies GmbH \& Co. KG, 2019. https://www.albertbauer.com/crossmedia-marketing/ [last accessed on 19.11.10].

Ardapedia: Mittelerde: Mordors Schatten. Arapedia, 2019, http://ardapedia.herr-der-ringe-film.de/ index.php/Mittelerde:_Mordors_Schatten [last accessed on 2019.10.18].

Ardapedia: Der Herr der Ring. Ardapedia, 2019, http://ardapedia.herr-der-ringe-film.de/index.php/ Der_Herr_der_Ringe [last accessed on 2019.10.18].

Ardapedia: Legendarium. Ardiapedia, 2019, http://ardapedia.herr-der-ringe-film.de/index.php/ Legendarium [last accessed on 2019.10.18].

Ardapedia: Der Hobbit (Comic). Ardapedia, 2019. http://ardapedia.herr-der-ringe-film.de/index. php/Der_Hobbit_(Comic) [last accessed on 2019.10.29].

A Song of Ice and Fire Wiki: A Song of Ice and Fire, FANDOM Books Community, Fandom, Inc., 2019, https://iceandfire.fandom.com/wiki/A_Song_of_Ice_and_Fire [last accessed on 2019.10.18].

A Wiki of Ice and Fire: A Game of Thrones (comics). A Wiki of Ice and Fire,2019. https://awoiaf. westeros.org/index.php/A_Game_of_Thrones_(comics) [last accessed on 2019.10.29].

Book Riot: AN EPIC LIST OF 29 GAME OF THRONES GAMES. https://bookriot.com/2019/06/05/ game-of-thrones-games/ [last accessed on 2019.11.02].

Bethesda.Elderscrolls: THE ELDER SCROLLS V: SKYRIM. Bethesda Softworks LLC, a ZeniMax Media company, 2019. https://elderscrolls.bethesda.net/de/skyrim [last accessed on 2019.10.18].

Brockhaus Enzyklopädie Online: Multimedia. NE GmbH | Brockhaus, 2019. https://brockhaus.de/ ecs/permalink/3887C77FD2797513924048AB847E44F4.pdf [last accessed on 19.11.11].

Brockhaus Enzyklopädie Online: Produktionsprogramm. NE GmbH | Brockhaus, 2019. https:// brockhaus.de/ecs/permalink/4D85A2F15053536A3B03886AC755DB1C.pdf [last accessed on 19.11.11].

Brockhaus Enzyklopädie Online: Sage. NE GmbH | Brockhaus, 2019, https://brockhaus.de/ecs/ permalink/DAD1F292751EEC94F609483A4DA28EA7.pdf [attended on 2019.09.30].

Brockhaus Enzyklopädie Online: Mythos. NE GmbH | Brockhaus, 2019, https://brockhaus.de/ecs/ permalink/A4C08F6CAF6B5CEBE9C3B665379EB21A.pdf [attended on 2019.09.27].

Brockhaus Enzyklopädie Online: Science Fiction. NE GmbH | Brockhaus, 2019, https://brockhaus. de/ecs/permalink/825FDD55C2A2E962E6AA53FD28578471.pdf [last accessed on 2019.10.07].

Brockhaus Enzyklopädie Online: Märchen. NE GmbH | Brockhaus, 2019, https://brockhaus.de/ecs/ permalink/453B77062986C05BE545A4FD9D83FADF.pdf [last accessed on 2019.09.30].

Brockhaus Enzyklopädie Online: Der Herr der Ringe. NE GmbH | Brockhaus, https://brockhaus.de/ ecs/permalink/F7784296CDF8E9BD91A87AA3455E4398.pdf [last acccessed on 2019.10.18].

Brockhaus Enzyklopädie Online: J.R.R. (John Ronald Reuel) Tolkien. NE GmbH | Brockhaus, 2019, https://brockhaus.de/ecs/permalink/A1BA1B4B7AAE49FCAF2DE3A90D44B222.pdf [last accessed on 2019.10.18].

CHIP: Witcher 3: Diese Spieldauer erwartet Sie. CHIP Digital GmbH, München, 2017. https:// praxistipps.chip.de/witcher-3-diese-spieldauer-erwartet-sie_96993 [last accessed on 2019.10.24].

Clark, Brian: Reclaiming Transmedia Storyteller (Facebook, 2011), (https://www.facebook. com/ notes/brian-clark/reclaiming-transmedia-storyteller/10150246236508993/ [last accessed on 
2019.07.04].

Diablo.Blizzard: The story of Diablio. Blizzard Entertainment, Inc, 2019. https://eu.diablo3.com/de/ game/the-story-of-diablo/?page $=4$ [last accessed on 2019.10.18].

Ebook Friendly: 15 most popular fanfiction websites to explore. Ebook Friendly - ebook geek heaven, Poland, 2018. https://ebookfriendly.com/fan-fiction-websites/\# [last accessed on 2019.10.28].

Fraunhofer: Grundlagen der medienneutralen Datenhaltung. Fraunhofer-Publica - Publication Database of the Fraunhofer-Gesellschaft, 1996. http://publica.fraunhofer.de/documents/ PX-16486.html [last accessed on 19.11.11].

Game of Thrones Wiki: Unterschiede zwischen Buch und Serie. Fandom, Fandom Inc. https:// gameofthrones.fandom.com/de/wiki/Unterschiede_zwischen_Buch_und_Serie [last accessed on 2019.10.30].

Hexer Wiki: CD Projekts The Witcher franchise. Gamepedia, Fandom Inc., 2019. https://hexer. gamepedia.com/CD_Projekts_The_Witcher_franchise\#Comics [last accessed on 2019.10.29].

Hexer Wiki: Der Hexer (Film). Fandom, Fandom Inc., 2019. https://hexer.gamepedia.com/Der_ Hexer_(Film) [last accessed on 2019.11.05].

Hon, Dan: Everything you know about ARGs is WRONG, https://www.sixtostart.com/onetread/2008/ everything-you-know-about-args-is-wrong/ [last accessed on 2019.08.11]

Jenkins, Henry: Transmedia Storytelling 101, (The Official Weblog of Henry Jenkins, 2007), http://henryjenkins.org/blog/2007/03/transmedia_storytelling_101.html [last accessed on 2019.08.19].

Jenkins, Henry: The Aesthetics of Transmedia: In Response to David Bordwell (Part One), (The Official Weblog of Henry Jenkins, 2009), http://henryjenkins.org/blog/2009/09/the_aesthetics_ of_transmedia_i.html [last accessed on 2019.08.23].

Jugend-Inforamtion-Medien: Leseverhalten von Jugendlichen, 2019. http://www.lesen-indeutschland.de/html/content.php?object=journal\&lid=1565 [last accessed on 2019.10.10].

Managementportal: Cross Media Publishing im Praxiseinsatz: Viele Vorteile bei wenig Aufwand. Managementortal.de, Recklies Management Project GmbH, 2015. https://www.managementportal.de/inhalte/artikel/fachbeitraege/14-marketing/519-cross-media-publishing-impraxiseinsatz-viele-vorteile-bei-wenig-aufwand.html [last accessed on 19.11.10].

Medien Community: Medienneutrale Daten. XXXX, 2013. https://mediencommunity.de/content/ u7-medienneutrale-daten [last accessed on 19.11.11].

PC Games: The Witcher 2 - Ergebnisse der Umfrage - Spielzeit, Wertung, Empfehlung. Computec Media GmbH, PCGames.de, 2011. https://www.pcgames.de/The-Witcher-2-Assassins-of-KingsSpiel-38487/Specials/The-Witcher-2-Umfrage-Ergebnis-Top-Rollenspiel-aber-Kritik-an-Aktivierung-Steuerung-und-NPCs-826911/5/ [last accessed on 2019.10.24].

PC Games: The Witcher Enhanced Edition im PC Games-Test. Computec Media GmbH, PCGames. de, 2008. https://www.pcgames.de/The-Witcher-Enhanced-Edition-Spiel-38489/Tests/TheWitcher-663212/ [last accessed on 2019.10.24].

Pokémon Wiki: The Pokémon Frachise. FANDOM Games Community, Fandom, Inc., 2019. https:// pokemon.fandom.com/wiki/Pok\%C3\%A9mon_(franchise) [last accessed on 2019.10.18].

Publisher: Publishing-3.0-Lösungen im Überflug, https://publisher.ch/publisher-archiv-detail-2. php?t=Publishing-3.0-L\%C3\%B6sungen+im+\%C3\%9Cberflug\&read_article=8012 [last accessed on 19.11.10].

Publisher: Medienproduktion - quo vadis, https://publisher.ch/publisher-archiv-detail-2.php?read_ article $=8022$ [last accessed on 19.11.10].

red-bean: XGF - An XML Game Format, https://www.red-bean.com/sgf/xml/ [last accessed on 2019.11.15]. 
Selfhtml: XML/Dialekte, https://wiki.selfhtml.org/wiki/XML/Dialekte [last accessed on November 11, 2019].

Selfhtml: XML/XSL/XSLT, https://wiki.selfhtml.org/wiki/XML/XSL/XSLT [last accessed on November 11, 2019].

Wattpad: Searching the catchwords "Game of Thrones", "A Song of Ice and Fire”, “The Hobbit", "The Witcher", "The Lord of the Ringe" and all respective German translations, with the searching-filter \#ff, \#fanfictions and without these filters. https://www.wattpad.com [last accessed on 2019.10.28].

WePC: 2019 Video Game Industry Statistics, Trends \& Data. 2019. https://www.wepc.com/news/ video-game-statistics/ [last accessed on 2019.10.18].

Wikipedia: Middle-Earth in video games. https://en.wikipedia.org/wiki/Middle-earth_in_video_ games [last accessed on 2019.11.02].

Wikipedia: Harry Potter video games. https://en.wikipedia.org/wiki/Harry_Potter_video_games [last accessed on 2019.11.02].

Witcher Wiki: CD Project's The Witcher Franchise. FANDOM Games Community, Fandom, Inc., 2019. https://witcher.fandom.com/wiki/CD_Projekt\%27s_The_Witcher_franchise [last accessed on 2019.10.18].

Witcher Wiki: The Witcher series. FANDOM Games Community, Fandom, Inc., 2019. https:// witcher.fandom.com/wiki/The_Witcher_series [last accessed on 2019.10.18].

Witcher Wiki: The Witcher Comics. Fandom, Fandom Inc. 2019. https://witcher.fandom.com/wiki/ The_Witcher_(comics) [last accessed on 2019.10.29].

World of Warcraft.Blizzard: The story of warcraft. Blizzard Entertainment, Inc, 2019. https:// worldofwarcraft.com/de-de/story/timeline [last accessed on 2019.10.18].

Youtube: The Witcher | Haupt-Trailer | Netflix (2019.10.31): YouTube Video added by Netflix Deutschland Östereich und Schweiz. Available at URL: https://www.youtube.com/watch?v=qAQutN0T2xI [last accessed on 2019.11.05]. 


\section{Statistics}

Bitkom. (2019): Anteil der Computer- und Videospieler in Deutschland im Jahr 2019 nach Geschlecht. Statista. Statista GmbH. https://de.statista.com/statistik/daten/studie/315920/umfrage/ anteil-der-computerspieler-in-deutschland-nach-geschlecht/ (Deutschland; Bitkom Research; 1.224 Befragte; ab 16 Jahre) [last accessed on 2019.10.14].

Bitkom. (2019): Welche der folgenden Computerspielarten spielen Sie zumindest gelegentlich?. Statista. Statista GmbH. https://de.statista.com/statistik/daten/studie/315938/umfrage/ umfrage-zu-den-bevorzugten-gaming-genres-in-deutschland/ ( Deutschland; Bitkom Research; 2019; 528 Gamer; ab 16 Jahre) [last accessed on 2019.10.14].

Börsenverein des Deutschen Buchhandels. (2019): Entwicklung des Umsatzanteils der Editionsform Science-Fiction und Fantasy in der Warengruppe Belletristik im Buchhandel in Deutschland in den Jahren 2009 bis 2018. Statista. Statista GmbH. https://de.statista.com/statistik/ daten/studie/984310/umfrage/entwicklung-des-umsatzanteils-der-editionsform-sciencefiction-und-fantasy-im-deutschen-buchhandel/ [last accessed on 2019.10.14].

Börsenverein des Deutschen Buchhandels. (2019): Entwicklung des Umsatzanteils der Editionsform Comic, Cartoon, Humor, Satire in der Warengruppe Belletristik im Buchhandel in Deutschland in den Jahren 2009 bis 2018. Statista. Statista GmbH. https://de.statista.com/ statistik/daten/studie/984334/umfrage/entwicklung-des-umsatzanteils-der-editionsformspannung-im-deutschen-buchhandel/ [last accessed on 2019.10.14].

Box Office Mojo. (2019): "Ranking der nach Einspielergebnis erfolgreichsten Filmreihen und -franchises weltweit bis Juli 2019 (in Milliarden US-Dollar).” Chart. 16. Juli, 2019. Statista. https://de.statista.com/statistik/daten/studie/932924/umfrage/erfolgreichste-filmreihen-undfranchises-nach-einspielergebnis/ [last accessed on 2019.10.14].

Brandt, M. (2018): Netflix setzt auf Comedy, Amazon auf Drama. Statista. Statista GmbH. https:// de.statista.com/infografik/15794/anzahl-genres-kommender-serien-von-video-streaminganbietern/ [last accessed on 2019.10.14].

German Federal Office of Statistics. (2017): Durchschnittliche Höhe der Konsumausgaben je Haushalt* im Monat in Deutschland nach Verwendungszweck im Jahr 2017. Statista, Statista GmbH, 2018. https://de.statista.com/statistik/daten/studie/164774/umfrage/konsumausgaben-privatehaushalte/ [last accessed on 2019.10.24].

German Federal Employment Agency. (2018): Verteilung der sozialversicherungspflichtigen Vollzeitbeschäftigten in Deutschland nach Einkommensgruppen (Bruttoeinkommen pro Monat) von 2011 bis 2017. Statista, Statista GmbH, 2018. https://de.statista.com/statistik/daten/ studie/577307/umfrage/verteilung-der-beschaeftigten-in-deutschland-nach-einkommensgruppen/ [last accessed on 2019.10.24].

IfD Allensbach. (2019): Beliebteste Fernsehformate in Deutschland in den Jahren 2017 bis 2019. Statista. Statista GmbH. https://de.statista.com/statistik/daten/studie/171208/umfrage/beliebteste-fernsehformate/ (Deutschland; 2017 bis 2019; ab 14 Jahre; deutschsprachige Bevölkerung; Persönliche Interviews) [last accessed on 2019.10.14].

IfD Allensbach. (2019): Bevölkerung in Deutschland nach Beliebtheit von Science-Fiction- und Fantasy-Filmen im Fernsehen von 2015 bis 2019 (Personen in Millionen). Statista. Statista GmbH. https://de.statista.com/statistik/daten/studie/171204/umfrage/interesse-an-sciencefiction-und-fantasy-filmen/ (Deutschland; 2015 bis 2019; ab 14 Jahre; deutschsprachige Bevölkerung; Persönliche Interviews) [last accessed on 2019.10.14]. 
Norstat. (2017): Welches Serien-Genre schaust Du am liebsten?. Statista. Statista GmbH. https:// de.statista.com/statistik/daten/studie/788528/umfrage/beliebtheit-von-serien-genres-indeutschland/ (20.11.2017; 1.416 Befragte; Online-Umfrage) [last accessed on 2019.10.14].

PwC. (2019): Wenn Sie im Internet unterwegs sind, um sich über verschiedene Dinge zu informieren, wie häufig nutzen Sie dabei die folgenden Online-Angebote?. Statista. Statista GmbH. Zugriff: https:/de.statista.com/statistik/daten/studie/4319/umfrage/genutzteinternetangebote-aus-dem-bereich-information/ (Deutschland; Oktober/November 2018; $\mathrm{N}=1.000$; ab 18 Jahre) [last accessed on 2019.10.14].

SPLENDID RESEARCH. (2018): Wie häufig spielen Sie die folgenden Spiele-Genres?. Statista. Statista GmbH. https://de.statista.com/statistik/daten/studie/942431/umfrage/umfrage-zuden-beliebtesten-genres-von-videospielen-in-deutschland/ (Deutschland; Juni und August 2018; 1.573 Spieler von Videospielen; 15-69 Jahre; Top-Two-Boxes "häufig", "sehr häufig") [last accessed on 2019.10.14].

Statista. (2016): Ranking der beliebtesten Fernsehserien in Deutschland im Jahr 2016. Statista. Statista GmbH, 2016. https://de.statista.com/statistik/daten/studie/581038/umfrage/rankingderbeliebtesten-fernsehserien-in-deutschland/ [last accessed on 2019.11.05].

Statista. (2018): Welche Genres lesen Sie regelmäßig?. Statista. Statista GmbH. https://de.statista. com/prognosen/803022/umfrage-in-deutschland-zu-beliebten-literatur-genres (Deutschland; 27.11. bis 05.12.2017; 1.025 Befragte; 18 bis 69 Jahre) [last accessed on 2019.10.14].

Statista. (2019): Welche Art Filme und Shows konsumieren Sie generell im Fernsehen (Übertragung/Kabel/Satellit)?. Statista. Statista GmbH. https://de.statista.com/prognosen/999813/ umfrage-in-deutschland-zu-beliebten-fernseh-genres (Deutschland; Statista; 29. Januar bis 13. März 2019; 923 Befragte; 18 bis 64 Jahre; Befragte, die fernsehen) [last accessed on 2019.10.14].

Statista. (2018): Welche der folgenden Geräte besitzen Sie in Ihrem Haushalt?, Statista, Statista GmbH, 2018. https://de.statista.com/statistik/daten/studie/476429/umfrage/geraetebesitz-fuerdenmedienkonsum-im-haushalt-in-deutschland/ [last accessed on 2019.11.08].

TV Series Finale. (2019): Anzahl der durchschnittlichen Zuschauer pro Staffel von Game of Thrones in den USA in den Jahren 2011 bis 2019 (in Millionen). Statista. Statista GmbH, 2019. https://de.statista.com/statistik/daten/studie/990751/umfrage/zuschauerzahl-pro-staffel-vongame-ofthrones/[last accessed on 2019.11.05].

VuMA (Arbeitsgemeinschaft Verbrauchs- und Medienanalyse). (2018): Frauen und Männer in Deutschland nach Häufigkeit des Spielens von Video-/ Computerspielen im Jahr 2018. Statista. Statista GmbH. https://de.statista.com/statistik/daten/studie/828207/umfrage/umfrage-unter-frauen-und-maennern-zur-haeufigkeit-des-spielens-von-computerspielen/ (Deutschland; IFAK; Ipsos; GfK Media and Communication Research; ab 14 Jahre; deutschsprachige Bevölkerung; Face-to-Face-Interviews) [last accessed on 2019.10.14].

VuMA (Arbeitsgemeinschaft Verbrauchs- und Medienanalyse). (2018): Studenten in Deutschland nach Nettoeinkommen im Vergleich mit der Bevölkerung im Jahr 2018. Statista, Statista GmbH, 2018, https://de.statista.com/statistik/daten/studie/860094/umfrage/ umfrage-in-deutschland-zum-nettoeinkommen-der-studenten/ [last accessed on 2019.10.24]. 


\section{Attachement A1}




\section{Total Results}

*The Fantasy franchise examples are abbreviated for better lucidity. Tolkien stands for Tolkien's Legendarium. GRRM stands für A Song of Ice and Fire/Game of Thrones. The Witcher stands for The Witcher/Geralt-Saga

\begin{tabular}{|c|c|c|c|c|c|c|c|}
\hline $\begin{array}{l}\text { exam- } \\
\text { ination } \\
\text { object }\end{array}$ & options & Tolkien* & GRRM* $^{*}$ & $\begin{array}{c}\text { The } \\
\text { Witcher* }^{\star}\end{array}$ & Total & $\begin{array}{r}\text { relative } \\
\text { freqency } \\
\text { from } \\
\text { the total } \\
\text { of the } \\
\text { option }\end{array}$ & $\begin{array}{l}\text { relative } \\
\text { frequen- } \\
\text { cy from } \\
\text { the total }\end{array}$ \\
\hline $\begin{array}{l}\text { partici- } \\
\text { pants }\end{array}$ & & 244 & 246 & 181 & 671 & - & $100 \%$ \\
\hline \multicolumn{8}{|c|}{ Personal data } \\
\hline \multirow[t]{3}{*}{ gender } & Male & 89 & 56 & 100 & 245 & - & $36.51 \%$ \\
\hline & Female & 152 & 190 & 81 & 423 & - & $63.04 \%$ \\
\hline & Diverse & 3 & 0 & 0 & 3 & - & $00.45 \%$ \\
\hline \multirow[t]{6}{*}{ age } & $12-17$ years old & 5 & 1 & 3 & 9 & - & $01.34 \%$ \\
\hline & 18-24 years old & 88 & 66 & 50 & 204 & - & $30.40 \%$ \\
\hline & 25-35 years old & 116 & 97 & 94 & 307 & - & $45.75 \%$ \\
\hline & 36-49 years old & 26 & 61 & 30 & 117 & - & $17.44 \%$ \\
\hline & 50-62 years old & 7 & 21 & 4 & 32 & - & $04.77 \%$ \\
\hline & over 62 years old & 2 & 0 & 0 & 2 & - & $00.30 \%$ \\
\hline \multirow[t]{6}{*}{$\begin{array}{l}\text { job } \\
\text { situation }\end{array}$} & $\begin{array}{l}\text { full time } \\
\text { employed }\end{array}$ & 83 & 116 & 102 & 301 & - & $44.86 \%$ \\
\hline & $\begin{array}{l}\text { half-time } \\
\text { employed }\end{array}$ & 28 & 38 & 12 & 78 & - & $11.62 \%$ \\
\hline & $\begin{array}{l}\text { university } \\
\text { student }\end{array}$ & 115 & 64 & 35 & 214 & - & $31.89 \%$ \\
\hline & trainee & 2 & 11 & 15 & 28 & - & $04.17 \%$ \\
\hline & school student & 5 & 1 & 2 & 8 & - & $01.19 \%$ \\
\hline & $\begin{array}{l}\text { currently } \\
\text { unemployed }\end{array}$ & 11 & 16 & 15 & 42 & - & $06.26 \%$ \\
\hline
\end{tabular}




\section{Results of consumption}

\begin{tabular}{|c|c|c|c|c|c|c|c|}
\hline $\begin{array}{l}\text { exam- } \\
\text { ination } \\
\text { object }\end{array}$ & options & Tolkien* & GRRM* & $\begin{array}{c}\text { The } \\
\text { Witcher* }\end{array}$ & Total & $\begin{array}{r}\text { relative } \\
\text { freqency } \\
\text { from } \\
\text { the total } \\
\text { of the } \\
\text { option }\end{array}$ & $\begin{array}{l}\text { relative } \\
\text { frequen- } \\
\text { cy from } \\
\text { the total }\end{array}$ \\
\hline \multirow{2}{*}{$\begin{array}{l}\text { Mother- } \\
\text { ship } \\
\text { media } \\
\text { type }\end{array}$} & book & 79 & 34 & 16 & 129 & - & $19.23 \%$ \\
\hline & non book & 165 & 212 & 165 & 542 & - & $80.77 \%$ \\
\hline \multirow{4}{*}{$\begin{array}{l}\text { book } \\
\text { media } \\
\text { type }\end{array}$} & total & 105 & 97 & 103 & 305 & $100.00 \%$ & $45.45 \%$ \\
\hline & $\begin{array}{l}\text { learning more } \\
\text { about the } \\
\text { storyworld }\end{array}$ & 83 & 73 & 95 & 251 & $82.30 \%$ & \\
\hline & $\begin{array}{l}\text { re-experience the } \\
\text { story on another } \\
\text { medium }\end{array}$ & 19 & 20 & 8 & 47 & $15.41 \%$ & \\
\hline & other reasons & 3 & 4 & 0 & 7 & $02.30 \%$ & \\
\hline \multirow{4}{*}{$\begin{array}{l}\text { film/TV } \\
\text { series } \\
\text { media } \\
\text { type }\end{array}$} & total & 86 & 32 & 85 & 203 & $100.00 \%$ & $30.25 \%$ \\
\hline & $\begin{array}{l}\text { learning more } \\
\text { about the } \\
\text { storyworld }\end{array}$ & 55 & 23 & 55 & 133 & $65.52 \%$ & \\
\hline & $\begin{array}{l}\text { re-experience the } \\
\text { story on another } \\
\text { medium }\end{array}$ & 25 & 9 & 27 & 61 & $30.05 \%$ & \\
\hline & other reasons & 6 & 0 & 3 & 9 & $04.43 \%$ & \\
\hline
\end{tabular}




\begin{tabular}{|c|c|c|c|c|c|c|c|}
\hline $\begin{array}{l}\text { examina- } \\
\text { tion object }\end{array}$ & options & Tolkien* & GRRM* & $\begin{array}{r}\text { The } \\
\text { Witcher* }\end{array}$ & Total & $\begin{array}{l}\text { relative } \\
\text { freqen- } \\
\text { cy from } \\
\text { the total } \\
\text { of the } \\
\text { option }\end{array}$ & $\begin{array}{l}\text { relative } \\
\text { frequen- } \\
\text { cy from } \\
\text { the total }\end{array}$ \\
\hline \multirow{4}{*}{$\begin{array}{l}\text { computer } \\
\text { game media } \\
\text { type }\end{array}$} & total & 130 & 46 & 15 & 191 & $100.00 \%$ & $28.46 \%$ \\
\hline & $\begin{array}{l}\text { learning more } \\
\text { about the } \\
\text { storyworld }\end{array}$ & 72 & 17 & 15 & 104 & $54.45 \%$ & \\
\hline & $\begin{array}{l}\text { re-experience } \\
\text { the story on } \\
\text { another } \\
\text { medium }\end{array}$ & 44 & 24 & 0 & 68 & $35.60 \%$ & \\
\hline & other reasons & 14 & 5 & 0 & 19 & $09.95 \%$ & \\
\hline \multirow{4}{*}{$\begin{array}{l}\text { comic/ } \\
\text { graphic } \\
\text { novel } \\
\text { media type }\end{array}$} & total & 84 & 17 & 47 & 148 & $100.00 \%$ & $22.06 \%$ \\
\hline & $\begin{array}{l}\text { learning more } \\
\text { about the } \\
\text { storyworld }\end{array}$ & 77 & 11 & 39 & 127 & $85.81 \%$ & \\
\hline & $\begin{array}{l}\text { re-experience } \\
\text { the story on } \\
\text { another } \\
\text { medium }\end{array}$ & 7 & 6 & 8 & 21 & $14.19 \%$ & \\
\hline & other reasons & 0 & 0 & 0 & 0 & $00.00 \%$ & \\
\hline \multirow{6}{*}{$\begin{array}{l}\text { website and } \\
\text { online wiki } \\
\text { media type }\end{array}$} & total & 168 & 203 & 165 & 536 & $100.00 \%$ & $79.88 \%$ \\
\hline & $\begin{array}{l}\text { learning more } \\
\text { about the } \\
\text { storyworld }\end{array}$ & 148 & 182 & 143 & 473 & $88.25 \%$ & \\
\hline & $\begin{array}{l}\text { get in touch } \\
\text { with other fans }\end{array}$ & 8 & 9 & 9 & 26 & $04.85 \%$ & \\
\hline & $\begin{array}{l}\text { read } \\
\text { fanfictions }\end{array}$ & 8 & 10 & 7 & 25 & $04.66 \%$ & \\
\hline & $\begin{array}{l}\text { publish } \\
\text { fanfictions }\end{array}$ & 1 & 1 & 2 & 4 & $00.75 \%$ & \\
\hline & other reasons & 3 & 1 & 4 & 8 & $01.49 \%$ & \\
\hline
\end{tabular}




\begin{tabular}{|c|c|c|c|c|c|c|c|}
\hline $\begin{array}{l}\text { examina- } \\
\text { tion object }\end{array}$ & options & Tolkien* & GRRM* & $\begin{array}{r}\text { The } \\
\text { Witcher* }\end{array}$ & Total & $\begin{array}{l}\text { relative } \\
\text { freqen- } \\
\text { cy from } \\
\text { the total } \\
\text { of the } \\
\text { option }\end{array}$ & $\begin{array}{l}\text { relative } \\
\text { frequen- } \\
\text { cy from } \\
\text { the total }\end{array}$ \\
\hline \multirow{4}{*}{$\begin{array}{l}\text { merchan- } \\
\text { dising } \\
\text { products }\end{array}$} & total & 134 & 164 & 100 & 398 & $100.00 \%$ & $59.31 \%$ \\
\hline & $\begin{array}{l}\text { learning more } \\
\text { about the } \\
\text { storyworld }\end{array}$ & 14 & 13 & 15 & 42 & $10.55 \%$ & \\
\hline & $\begin{array}{l}\text { re-experience } \\
\text { the story on } \\
\text { another } \\
\text { medium }\end{array}$ & 98 & 130 & 78 & 306 & $76.88 \%$ & \\
\hline & other reasons & 22 & 21 & 7 & 50 & $12.56 \%$ & \\
\hline
\end{tabular}

\section{Results of non-consumption}

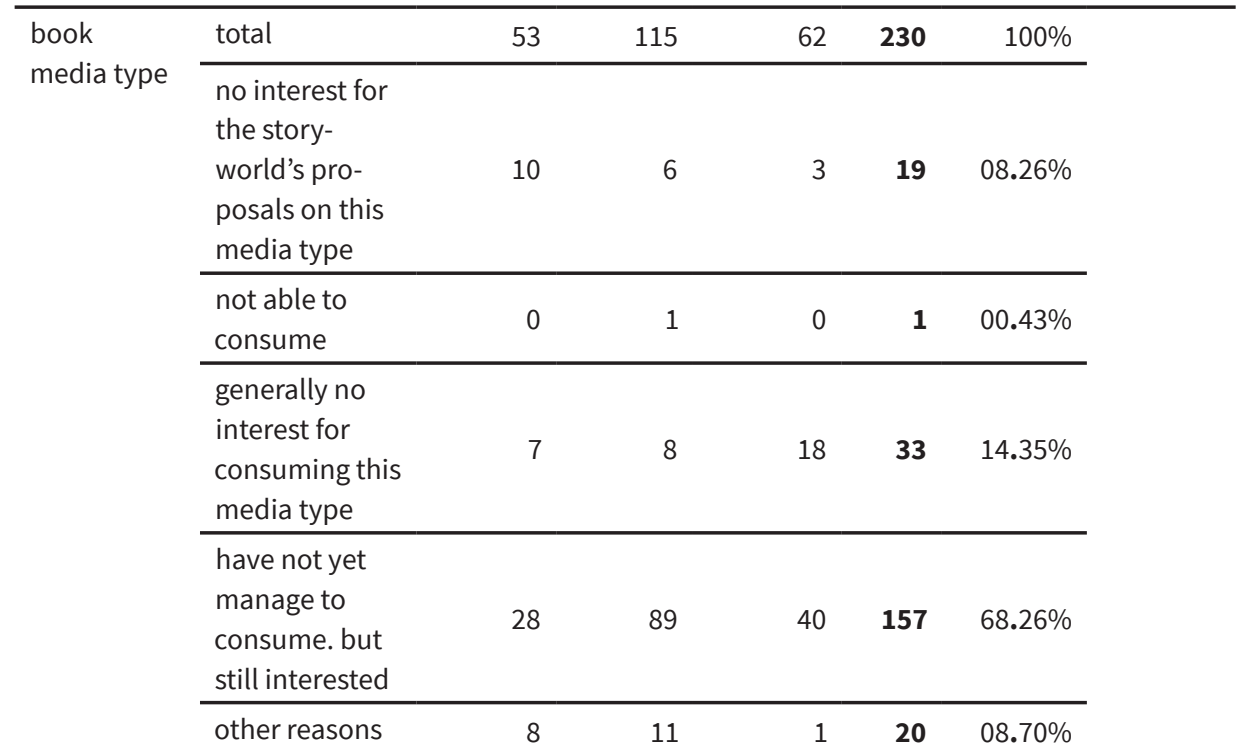




\begin{tabular}{|c|c|c|c|c|c|c|c|}
\hline $\begin{array}{l}\text { exam- } \\
\text { ination } \\
\text { object }\end{array}$ & options & Tolkien* & GRRM* & $\begin{array}{c}\text { The } \\
\text { Witcher* }\end{array}$ & $\begin{array}{l}\text { To- } \\
\text { tal }\end{array}$ & $\begin{array}{l}\text { relative fre- } \\
\text { qency from } \\
\text { the total of } \\
\text { the option }\end{array}$ & $\begin{array}{l}\text { relative } \\
\text { frequen- } \\
\text { cy from } \\
\text { the total }\end{array}$ \\
\hline \multirow{6}{*}{$\begin{array}{l}\text { film/TV } \\
\text { series } \\
\text { media } \\
\text { type }\end{array}$} & total & 0 & 2 & 96 & 98 & $100 \%$ & \\
\hline & $\begin{array}{l}\text { no interest } \\
\text { for the } \\
\text { storyworld's } \\
\text { proposals on } \\
\text { this media } \\
\text { type }\end{array}$ & 0 & 0 & 3 & 3 & $03.06 \%$ & \\
\hline & $\begin{array}{l}\text { not able to } \\
\text { consume }\end{array}$ & 0 & 0 & 0 & 0 & $00.00 \%$ & \\
\hline & $\begin{array}{l}\text { generally no } \\
\text { interest for } \\
\text { consuming } \\
\text { this media } \\
\text { type }\end{array}$ & 0 & 1 & 2 & 3 & $03.06 \%$ & \\
\hline & $\begin{array}{l}\text { have not yet } \\
\text { manage to } \\
\text { consume but } \\
\text { still interested }\end{array}$ & 0 & 1 & 85 & 86 & $89.58 \%$ & \\
\hline & other reasons & 0 & 0 & 6 & 6 & $08.70 \%$ & \\
\hline \multirow{6}{*}{$\begin{array}{l}\text { computer } \\
\text { game } \\
\text { media } \\
\text { type }\end{array}$} & total & 114 & 200 & 1 & 315 & $100 \%$ & \\
\hline & $\begin{array}{l}\text { no interest } \\
\text { for the } \\
\text { storyworld's } \\
\text { proposals on } \\
\text { this media } \\
\text { type }\end{array}$ & 27 & 43 & 0 & 70 & $22.22 \%$ & \\
\hline & $\begin{array}{l}\text { not able to } \\
\text { consume }\end{array}$ & 4 & 6 & 0 & 10 & $03.17 \%$ & \\
\hline & $\begin{array}{l}\text { generally no } \\
\text { interest for } \\
\text { consuming } \\
\text { this media } \\
\text { type }\end{array}$ & 51 & 79 & 0 & 130 & $41.27 \%$ & \\
\hline & $\begin{array}{l}\text { have not yet } \\
\text { manage to } \\
\text { consume. but } \\
\text { still interested }\end{array}$ & 25 & 64 & 0 & 89 & $28.25 \%$ & \\
\hline & other reasons & 7 & 8 & 1 & 16 & $05.08 \%$ & \\
\hline
\end{tabular}




\begin{tabular}{|c|c|c|c|c|c|c|c|}
\hline $\begin{array}{l}\text { exam- } \\
\text { ination } \\
\text { object }\end{array}$ & options & Tolkien* & GRRM* & $\begin{array}{c}\text { The } \\
\text { Witcher* }\end{array}$ & $\begin{array}{l}\text { To- } \\
\text { tal }\end{array}$ & $\begin{array}{l}\text { relative fre- } \\
\text { qency from } \\
\text { the total of } \\
\text { the option }\end{array}$ & $\begin{array}{l}\text { relative } \\
\text { frequen- } \\
\text { cy from } \\
\text { the total }\end{array}$ \\
\hline \multirow{6}{*}{$\begin{array}{l}\text { comic/ } \\
\text { graphic } \\
\text { novel } \\
\text { media } \\
\text { type }\end{array}$} & total & 226 & 229 & 134 & 589 & $100 \%$ & \\
\hline & $\begin{array}{l}\text { no interest } \\
\text { for the } \\
\text { storyworld's } \\
\text { proposals on } \\
\text { this media } \\
\text { type }\end{array}$ & 36 & 36 & 3 & 75 & 12.73 & \\
\hline & $\begin{array}{l}\text { not able to } \\
\text { consume }\end{array}$ & 0 & 3 & 1 & 4 & $0.68 \%$ & \\
\hline & $\begin{array}{l}\text { generally no } \\
\text { interest for } \\
\text { consuming } \\
\text { this media } \\
\text { type }\end{array}$ & 103 & 132 & 67 & 302 & $51.37 \%$ & \\
\hline & $\begin{array}{l}\text { have not yet } \\
\text { manage to } \\
\text { consume. but } \\
\text { still interested }\end{array}$ & 61 & 45 & 48 & 154 & $26.15 \%$ & \\
\hline & other reasons & 26 & 13 & 15 & 54 & $09.17 \%$ & \\
\hline
\end{tabular}




\begin{tabular}{|c|c|c|c|c|c|c|c|}
\hline $\begin{array}{l}\text { examina- } \\
\text { tion object }\end{array}$ & options & Tolkien* & GRRM* & $\begin{array}{c}\text { The } \\
\text { Witcher* }\end{array}$ & Total & $\begin{array}{r}\text { relative } \\
\text { freqency } \\
\text { from } \\
\text { the total } \\
\text { of the } \\
\text { option }\end{array}$ & $\begin{array}{l}\text { relative } \\
\text { frequen- } \\
\text { cy from } \\
\text { the total }\end{array}$ \\
\hline \multirow{6}{*}{$\begin{array}{l}\text { website } \\
\text { and online } \\
\text { wiki media } \\
\text { type }\end{array}$} & total & 75 & 43 & 16 & 134 & $100 \%$ & \\
\hline & $\begin{array}{l}\text { no interest for } \\
\text { the story- } \\
\text { world's } \\
\text { proposals on } \\
\text { this media } \\
\text { type }\end{array}$ & 41 & 13 & 6 & 60 & $44.78 \%$ & \\
\hline & $\begin{array}{l}\text { not able to } \\
\text { consume }\end{array}$ & 0 & 0 & 0 & 0 & $00.00 \%$ & \\
\hline & $\begin{array}{l}\text { generally no } \\
\text { interest for } \\
\text { consuming this } \\
\text { media type }\end{array}$ & 15 & 16 & 3 & 34 & $25.37 \%$ & \\
\hline & $\begin{array}{l}\text { have not yet } \\
\text { manage to } \\
\text { consume. but } \\
\text { still interested }\end{array}$ & 16 & 13 & 4 & 33 & $24.63 \%$ & \\
\hline & other reasons & 3 & 1 & 3 & 7 & $05.22 \%$ & \\
\hline \multirow{5}{*}{$\begin{array}{l}\text { merchan- } \\
\text { dising } \\
\text { products }\end{array}$} & total & 110 & 82 & 81 & 273 & $100 \%$ & \\
\hline & $\begin{array}{l}\text { no interest for } \\
\text { the story- } \\
\text { world's } \\
\text { proposals on } \\
\text { this media } \\
\text { type }\end{array}$ & 44 & 22 & 11 & 77 & $28.21 \%$ & \\
\hline & $\begin{array}{l}\text { generally no } \\
\text { interest for } \\
\text { consuming this } \\
\text { media type }\end{array}$ & 21 & 23 & 29 & 73 & $41.39 \%$ & \\
\hline & $\begin{array}{l}\text { have not yet } \\
\text { manage to } \\
\text { consume but } \\
\text { still interested }\end{array}$ & 2 & 5 & 3 & 10 & $26.74 \%$ & \\
\hline & other reasons & 7 & 8 & 1 & 16 & $03.66 \%$ & \\
\hline
\end{tabular}


Distribution of the Mothership's choice

The

\begin{tabular}{lrrrrrr} 
options & & Tolkien* & & GRRM $^{*}$ & & Witcher $^{*}$ \\
\hline Mothership book & 79 & $31.00 \%$ & 34 & $13.00 \%$ & 16 & $8.80 \%$ \\
\hline Mothership non-book & 158 & $64.00 \%$ & 212 & $86.00 \%$ & 165 & $91.20 \%$ \\
\hline $\begin{array}{l}\text { interviewee read the books } \\
\text { afterwards }\end{array}$ & 105 & $66.46 \%$ & 97 & $45.75 \%$ & 103 & $62.42 \%$ \\
\hline $\begin{array}{l}\text { interviewee is still interest- } \\
\text { ed to read the books }\end{array}$ & 28 & $17.22 \%$ & 89 & $41.98 \%$ & 40 & $24.24 \%$ \\
\hline $\begin{array}{l}\text { interviewee has no } \\
\text { interest to read the books }\end{array}$ & 25 & $15.82 \%$ & 26 & $12.26 \%$ & 22 & $13.33 \%$
\end{tabular}



Attachement A2 


\section{Survey's structure and results in Detail}

\section{Konsum von Fantasy Medien}

\section{$\Xi$ survio}

www.survio.com 


\section{Ėsurvio}

\section{Allgemeines}

Öffentliche Web-Adresse der Umfrage (URL) https://www.survio.com/survey/d/B4E106V106T3G9C7Q 


\section{Umfrage Besucher}

$\begin{array}{ccccc}884 & 683 & 0 & 201 & 77,3 \% \\ \begin{array}{c}\text { Insgesamt } \\ \text { Besuche }\end{array} & \begin{array}{c}\text { Fertige } \\ \text { Antworten }\end{array} & \begin{array}{c}\text { Unvollendete } \\ \text { Antworten }\end{array} & \text { Nur gezeigt } & \begin{array}{c}\text { Insgesamt } \\ \text { Abschlussquote }\end{array}\end{array}$

Besuch Historie (08. 09. 2019 - 29. 09. 2019)

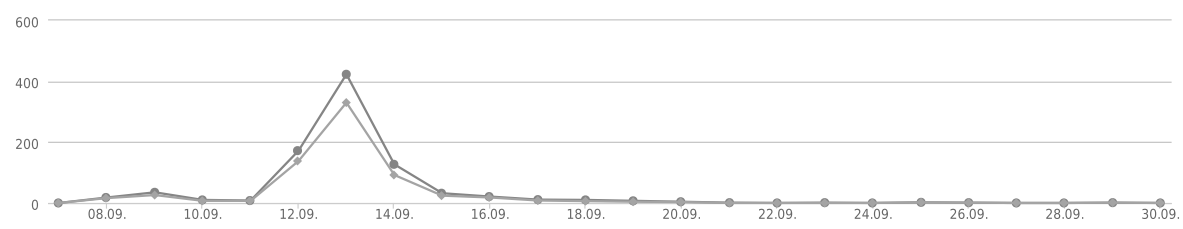

- Insgesamt Besuche (884) Fertige Antworten (683)

Besucher total

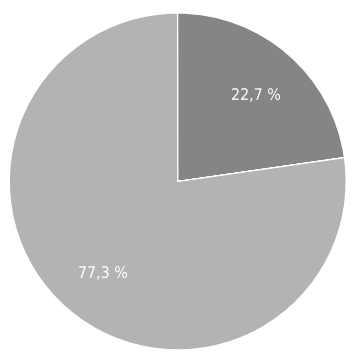

Besuchen Quellen

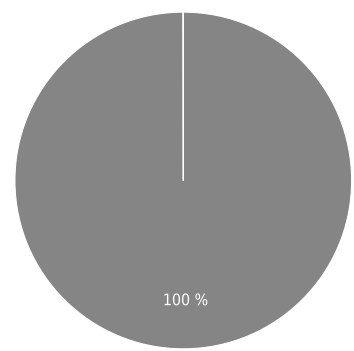

Durchschnittliche Zeit der Fertigstellung

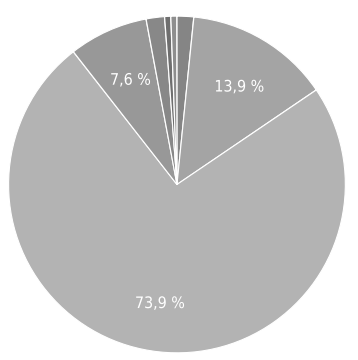


- Nur gezeigt $(22,7 \%)$

- Unvollständige (0\%)

- Abgeschlossene (77,3\%)
- Direkter Link (100 \%)

$$
\begin{aligned}
& -<1 \mathrm{~min} .(1,6 \%) \\
& -1-2 \mathrm{~min} .(13,9 \%) \\
& -2-5 \mathrm{~min} .(73,9 \%) \\
& -5-10 \mathrm{~min} .(7,6 \%) \\
& -10-30 \mathrm{~min} .(1,8 \%) \\
& -30-60 \mathrm{~min} .(0,6 \%) \\
& ->60 \mathrm{~min} .(0,6 \%)
\end{aligned}
$$




\section{Elsurvio}

\section{Ergebnisse}

Bitte gib an, wie viele von den drei Beispielen du bereits bewusst medial konsumiert hast?

Einzelwahl, geantwortet 683x, unbeantwortet ox

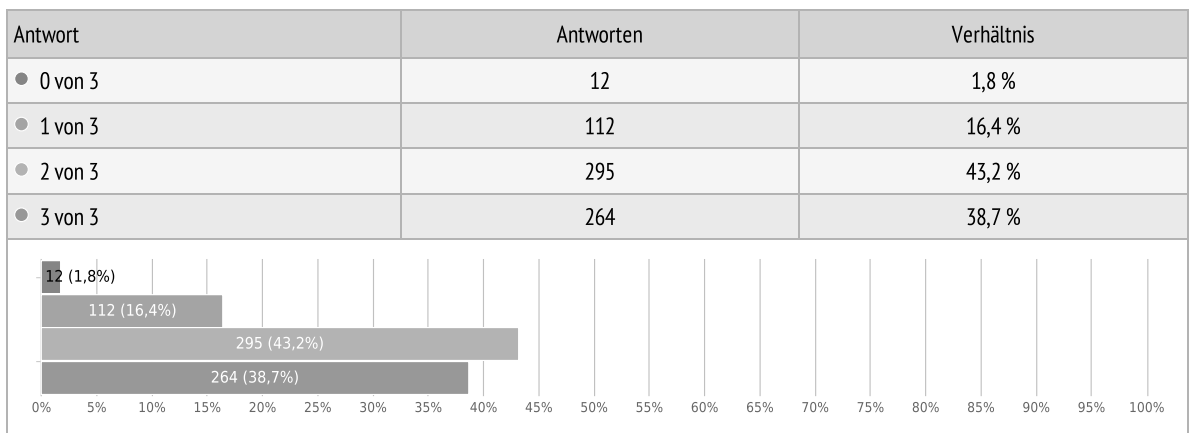

Bitte wähle die Fantasywelt aus, mit der du dich am MEISTEN beschäftigt hast Einzelwahl, geantwortet $671 x$, unbeantwortet $12 x$

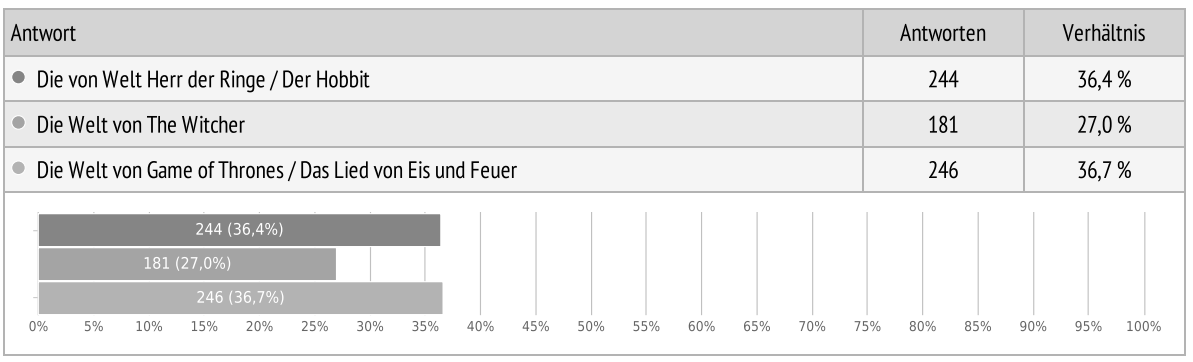




\section{Istsurvio}

\section{Hast du zuerst die Bücher gelesen oder die Filme gesehen?}

Einzelwahl, geantwortet $244 x$, unbeantwortet $439 x$

\begin{tabular}{|l|l|l|l|l|l|}
\hline Antwort & & Antworten & Verhältnis \\
\hline Buch / Roman Reihe & & 77 & $31,6 \%$ \\
\hline
\end{tabular}

- Wenn bezogen auf HdR - Filme. Wenn im Durchschnitt - Erst die Bücher.

- Bücher, Filme und diverse Spiele

- Bei Herr der Ringe zuerst die Filme und bei " das lied von Eis und Feuer " zuerst die Bücher

- Film und Spiel

- Nur Filme bisher

- Beides

- Nach dem ersten Film habe ich mir die Bücher gekauft und alle gelesen, weil ich nicht abwarten konnte, wie es weitergeht.

- Beim Hobbit erst das Buch, bei HdR nur Filme

- Hörspiel

\section{Hast du schon einmal einen Film der "Der Herr der Ringe" oder "Der Hobbit"} Trilogie gesehen?

Einzelwahl, geantwortet 86x, unbeantwortet $597 x$

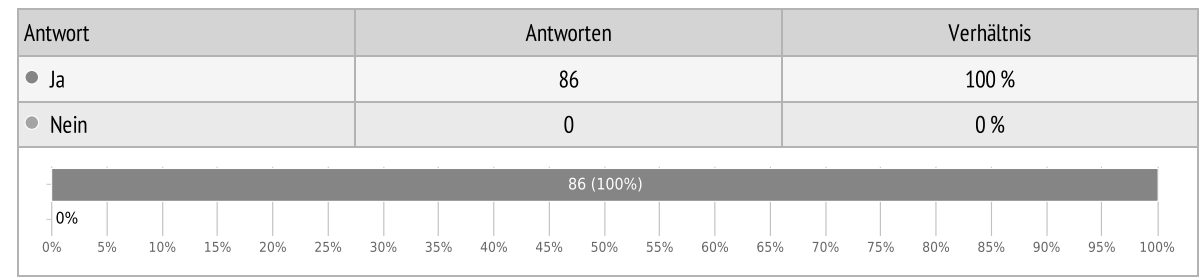




\section{Als du die Filme gesehen hast, wolltest du...}

Einzelwahl, geantwortet 86x, unbeantwortet $597 x$

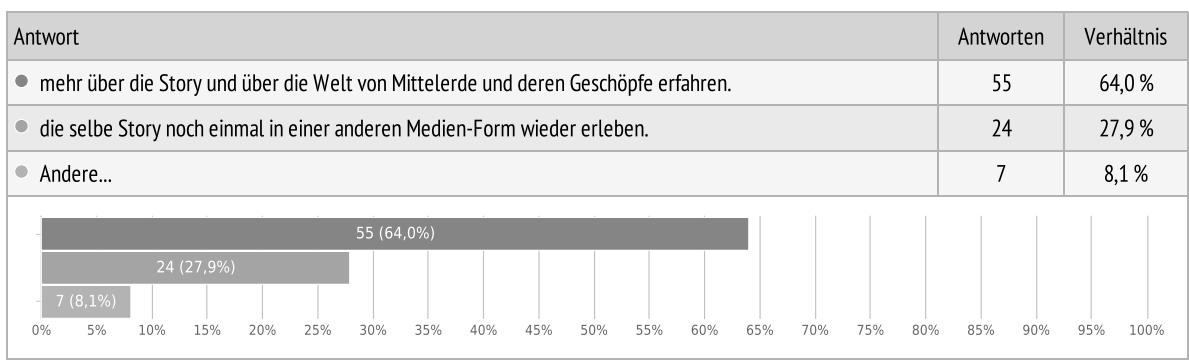

- Nicht weiter verfolgen

- Ich wollte die Filme immer wieder schauen. Denn Mittelerde kannte ich bereits seit Jahren durch die Bücher. Und ich wollte selbst Abenteuer in Mittele

- Ins Bett und schlafen (Überlänge der Filme, gemütlicher Filmabend)

- nüscht

- ich hab mich über die unnützen Abweichungen in der Geschichte geärgert

-.schauen ob es zu der eigenen Fantasie passt

- Sehen, wie die filmische Umsetzung zum Buch gemacht wurde

Nein, weil...

Einzelwahl, geantwortet $0 x$, unbeantwortet $683 x$

Hast du schon einmal ein Buch gelesen, dessen Story in Mittelerde stattfindet?

Einzelwahl, geantwortet 158x, unbeantwortet 525x

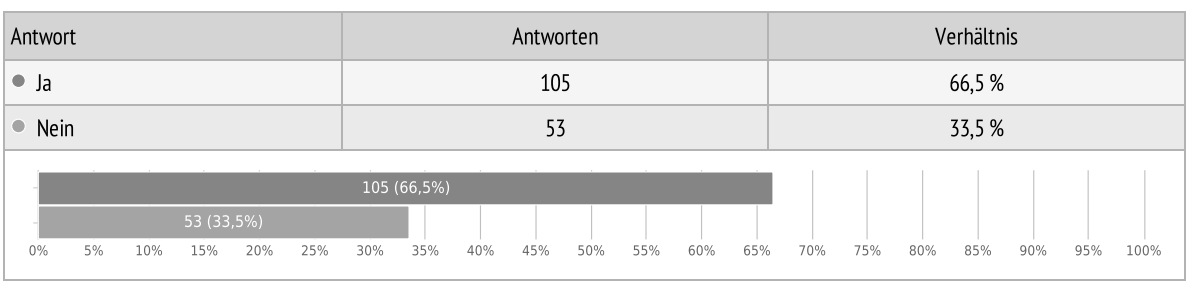




\section{Istsurvio}

\section{Als ich die Bücher gelesen habe, wollte ich ...}

Einzelwahl, geantwortet 105x, unbeantwortet $578 x$

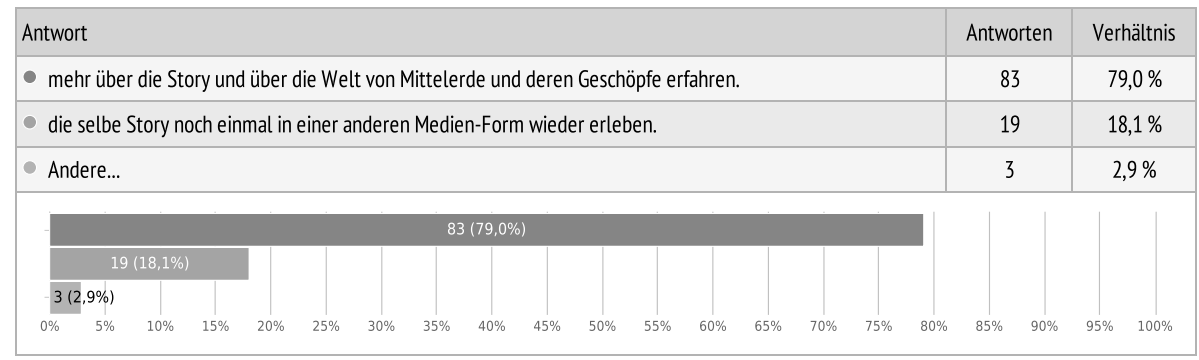

- eine gute Geschichte lesen.

- den viel gelobten, komplizierten Schreibstil erleben.

- ein anderes Buch zur Hand nehmen, da es ziemlich langatmig geschrieben war.

\section{Nein, weil...}

Einzelwahl, geantwortet $53 x$, unbeantwortet $630 x$

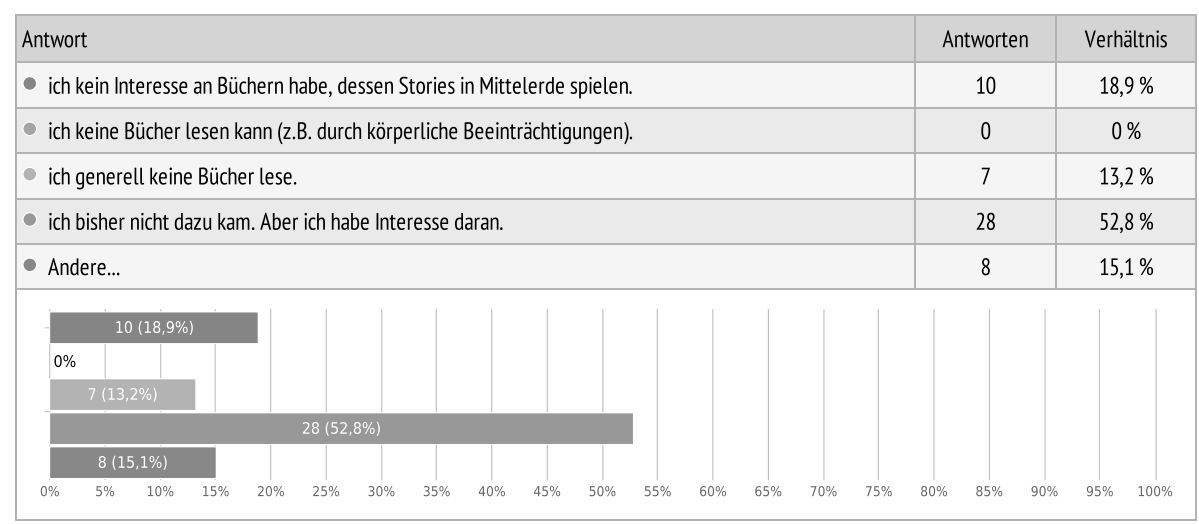

- Die Bücher verlieren für mich an Reiz, wenn durch den Film bereits feste Vorstellungen der Szenerie/Charaktere erzeugt werden

- alle Teile als Hörbuch angehört

- Ich habe es angefangen, aber die Mittelerde Bücher sind immer soooo ausführlich

ich ein Hörbuch - Originaltext - dazu habe und Tolkiens Schreibstil furchtbar finde 


\section{Esurvio}

- Ich es visuell schöner finde

- ich keine Zeit dafür habe

- Ich bevorzuge Filme. Für entsprechende Bücher mit diesem Zeitaufwand fehlt mir die Geduld.

- Weil diese Bücher mir zu langatmig sind

\section{Hast du schon einmal ein Computerspiel gespielt, dessen Story in Mittelerde}

\section{stattfindet?}

Einzelwahl, geantwortet 244x, unbeantwortet $439 x$

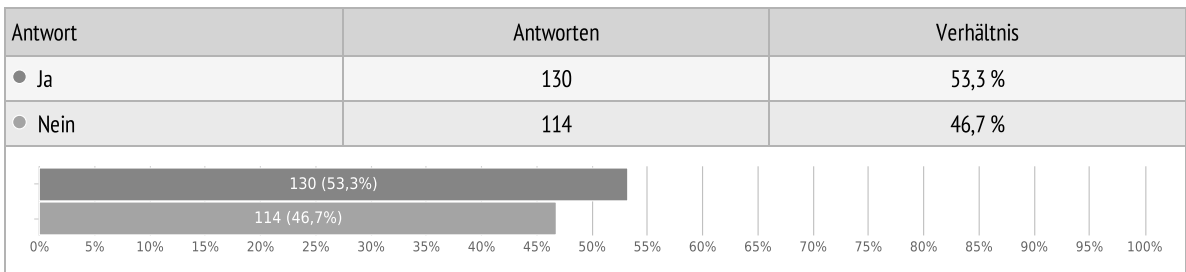

Als ich das Computerspiel gespielt habe, wollte ich...

Einzelwahl, geantwortet 130x, unbeantwortet 553x

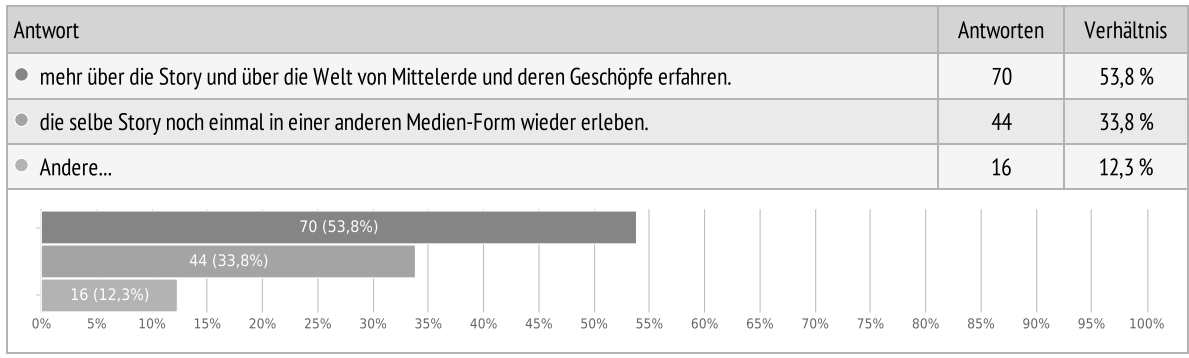

- In eine andere Story dieser Welt eintauchen

- Kein weiterer Konsumwillen.

- Selbst an der Welt teilhaben

- Nicht mehr spielen, mehr lesen

- Nichts

- Selbst in dieser Welt agieren

- Orks kloppen

- In die Welt von Mittelerde eintauchen 


\section{Esturvio}

- obskure Spiele spielen

- Interesse am Spiel an sich

- Einfach ein Spiel in meiner Liblingswelt spielen

- Spass haben

- Weiß ich nicht genau

- Möglichst viel im Spiel von dem wiederfinden, was ich aus den Filmen kannte und ein gute Story.

- selbst Teil der Geschichte werden und mich frei in deren Universum bewegen

- nichts weiter tun

\section{Nein, weil...}

Einzelwahl, geantwortet $114 x$, unbeantwortet $569 x$

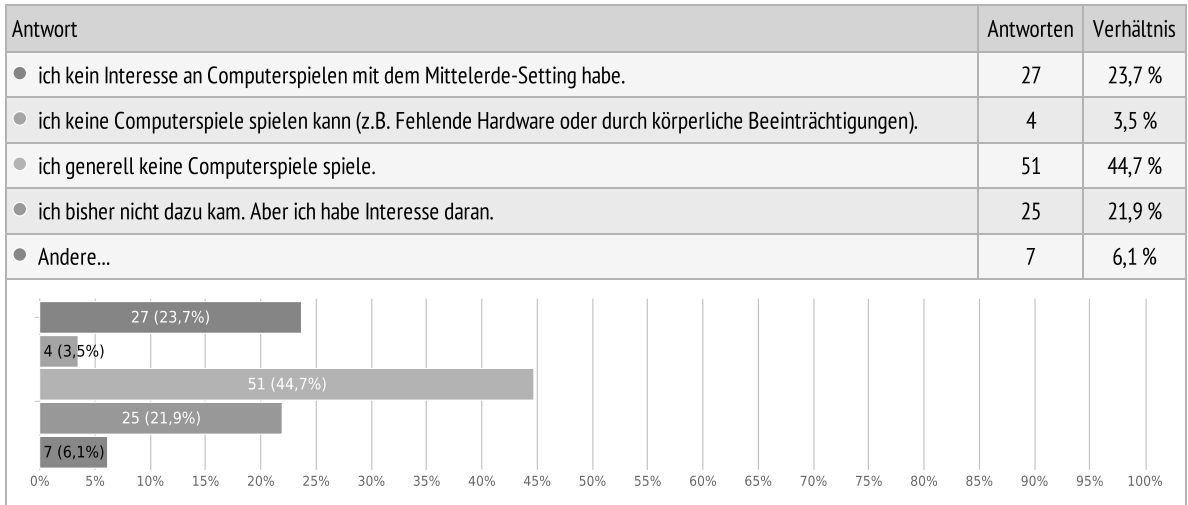

- Habe mal gezockt. Ist aber zeitlich nicht mehr möglich

- Ich GW2 zocke

- mich andere Computerspiele mehr interessieren

- Die bisherigen Spiele auf den Markt nicht gut.

- Die Spiele von denen ich gehört habe, für meinen Geschmack zu kriegsorientiert waren

- Kein gutes Spiel existiert, welches in Mittelerde spielt

- ich lieber Let's Plays ansehe, statt selber zu spielen. 
Hast du schon einmal einen Comic gelesen, dessen Story in Mittelerde stattfindet? Einzelwahl, geantwortet 244x, unbeantwortet $439 x$

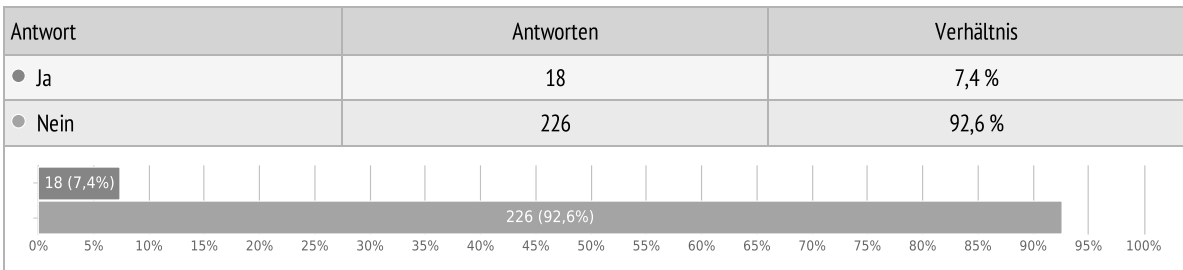

Als ich den Comic gelesen habe, wollte ich ...

Einzelwahl, geantwortet $18 x$, unbeantwortet $665 x$

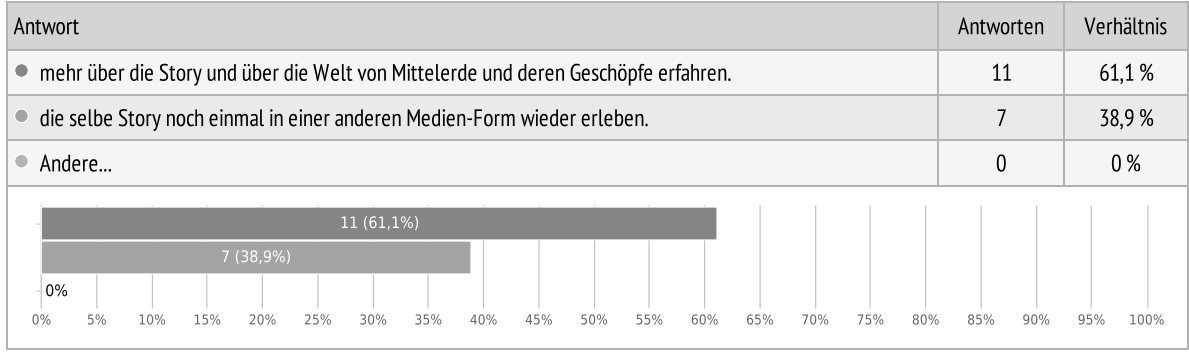




\section{İsurvio}

\section{Nein, weil...}

Einzelwahl, geantwortet 226x, unbeantwortet $457 x$

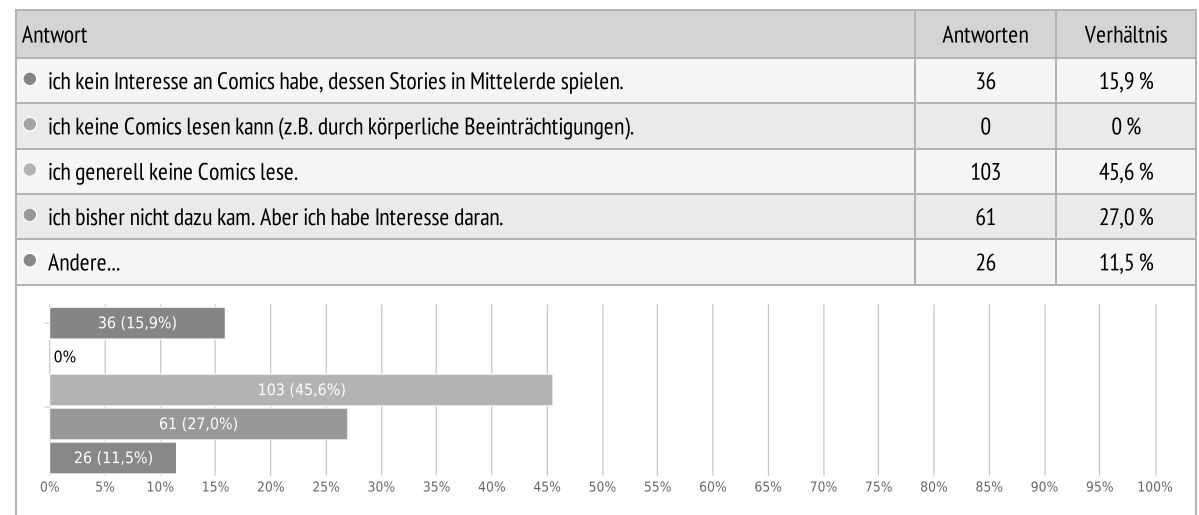

- Ich gar nicht wüsste, dass dieser Comic existiert.

- Den Comic hab ich noch nicht gesehen.

- Ich kannte die Comics nicht

- ich die Comics noch gar nicht kenne.

- Ich noch nicht einmal wusste, dass es Comics über Mittelerde gibt.

- ich bis jetzt nicht wusste, dass es in diesem Franchise Comics gibt

- Interessiert mch tatsächlich nicht so stark

- ich bin einfach noch nie auf die Idee gekommen.

- Bin noch an keins rangekommen, sonst bestimmt

- weil ich nicht wusste, dass es dazu einen Comic gibt.

- Ich nicht wusste das es auch comics davon gibt

- ich wusste nicht, dass es auch Comics in Mittelerde gibt.

- Ich nicht wusste das es mittelerde comics gibt

- ich es nicht kannte

- existenz war mir nicht bewusst

- ich nicht wusste, das es Mittelerde-Comics gibt.

- Kein gutes Spiel existiert

- Nicht wusste, dass es solche Comics gibt

- ich nicht wusste, dass es Comics dazu gab. Aber ich habe Interesse.

- Noch keinen gefunden, der mir vom Stil her gefällt.

- ich nicht wusste, dass es solche Comics gibt. 
- ich bis jetzt nicht wusste, dass es einen Comic dazu gibt.

- war mir nicht bewusst, dass es sowas gibt.

- Mir fehlt die Zeit neben Buch, Film und Spiel noch zum Comic lesen zu kommen. Außerdem kommen Comics immer wöchentlich raus, was ich nicht gut finde

- Ich nicht wusste das es Comics zu Mittelerde gibt. Bei Comics bin ich lieber in Gotham oder Metropolis. (:)

- Ist mir bisher nicht über den Weg gelaufen.

Hast du schon einmal eine Webseite oder ein Online-Wiki genutzt, dessen Inhalte sich auf die Welt von Mittelerde beziehen?

Einzelwahl, geantwortet 244x, unbeantwortet $439 x$

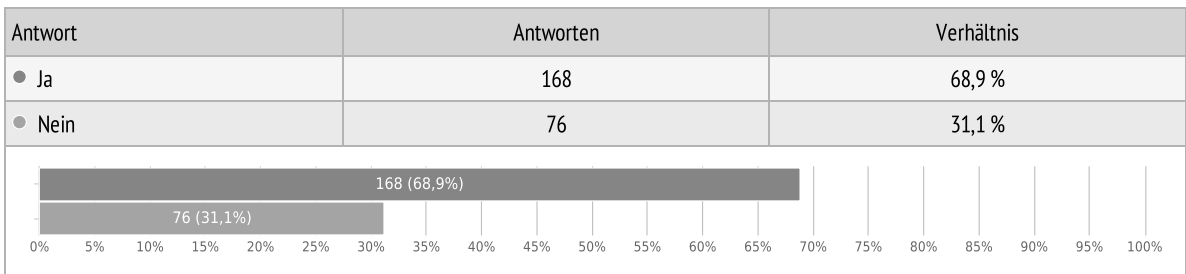

Als ich die Webseite bzw. das Online-Wiki besucht habe, wollte ich ...

Einzelwahl, geantwortet 168x, unbeantwortet 515x

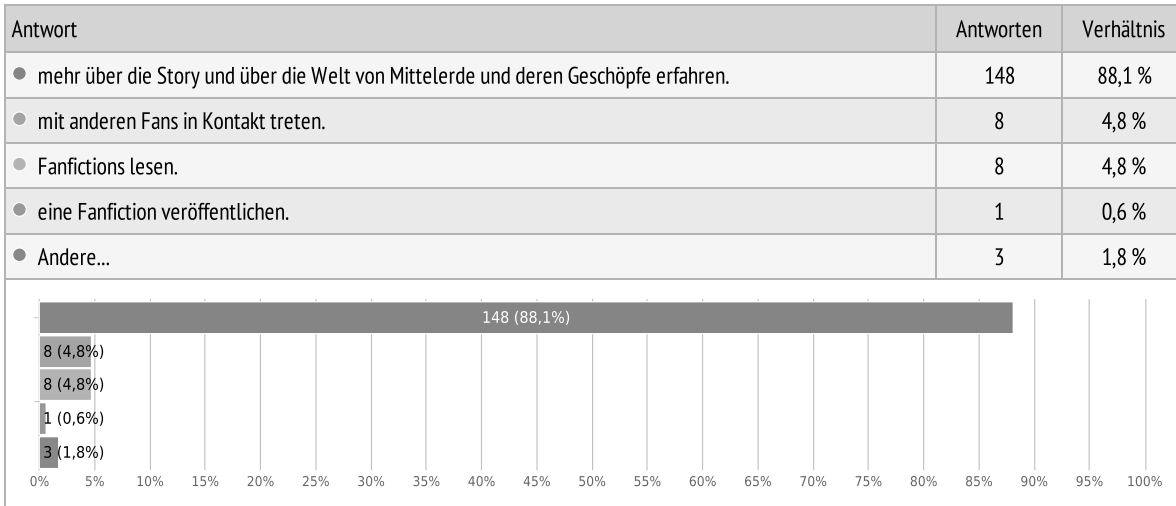

- Die Sprache der Orks lernen.

- Die Bücher waren verwirrend und ich brauchte eine Personenerklärung 


\section{Elsurvio}

- Ein Abenteuer vorbereiten

Nein, weil...

Einzelwahl, geantwortet $75 x$, unbeantwortet $608 x$

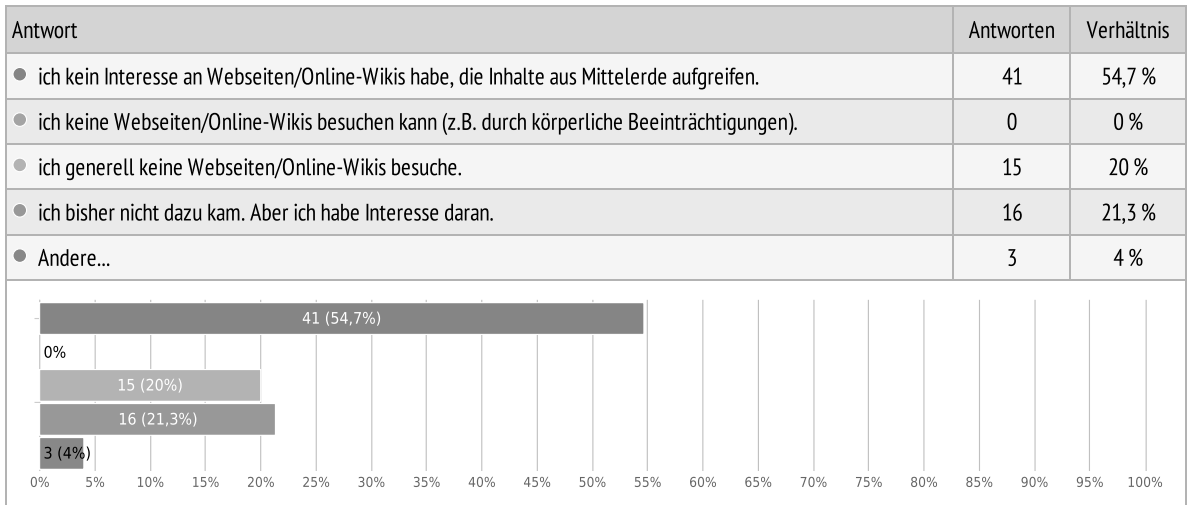

- ich mir zu diesem Thema keine Fragen gestellt habe deren Antworten man in einem Wiki nachlesen müsste.

weil ich davon nichts wusste.

- Nicht wusste dass diese existieren

\section{Hast du schon einmal Merchandise-Produkte mit Bezug zu "Der Herr der Ringe" oder "Der Hobbit" gekauft?}

Einzelwahl, geantwortet $244 x$, unbeantwortet $439 x$

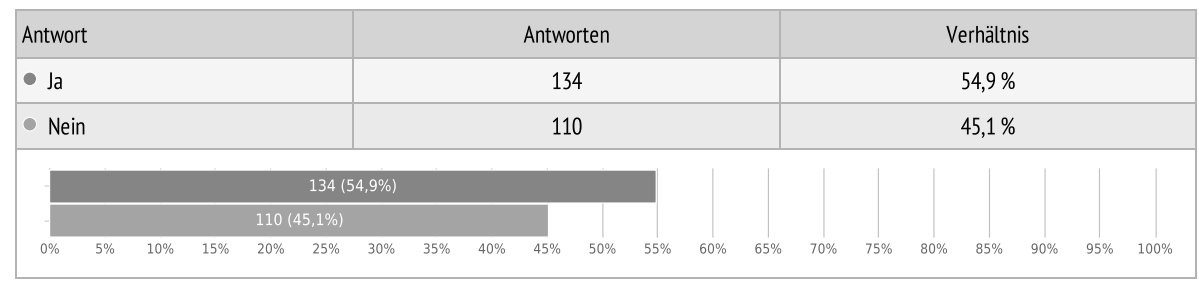




\section{Als ich diese Merchandise-Produkte gekauft habe, wollte ich...}

Einzelwahl, geantwortet $134 x$, unbeantwortet 549x

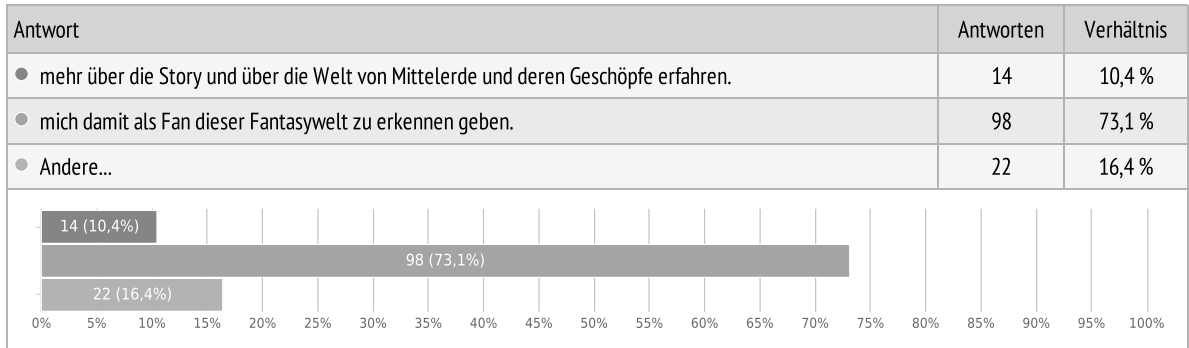

- einen Sammelaspekt befriedigen

- Mir persönlich eine Freude bereiten

- Geschenk

- es weiter verschenken.

- Meine Merch-Sammlung erweitern

- Mehr merch

- Mich als Teil der Welt fühlen

- Zimmer verschönern

- Meine Faszination ausleben

- Ich mag Figuren aus Mittelerde

- sie haben, weil sie mir gefallen haben

- Ein Geschenk machen

- Figuren gesammelt habe

- Nostalgie

- Ich wollte es haben weil ich es schön fand

- Ich fand das einfach ansprechend

- Habe alle Figuren der Story gesammelt und in die Vitrine gestellt. Erfreue mich heute noch daran.

- Mich mehr mit dem Thema identifizieren

- Für eine Freundin die ebenfalls Fan ist

- Einen Teil der Fantasy Welt in meiner Sammlung zu haben

- Das als Fan einfa h haben. Nicht, um zu zeigen, dass ich Fan bin, sondern so für mich selbst.

- einen Teil der fiktiven Welt in mein reales Umfeld holen 


\section{Esurvio}

\section{Nein, weil...}

Einzelwahl, geantwortet 110x, unbeantwortet $573 x$

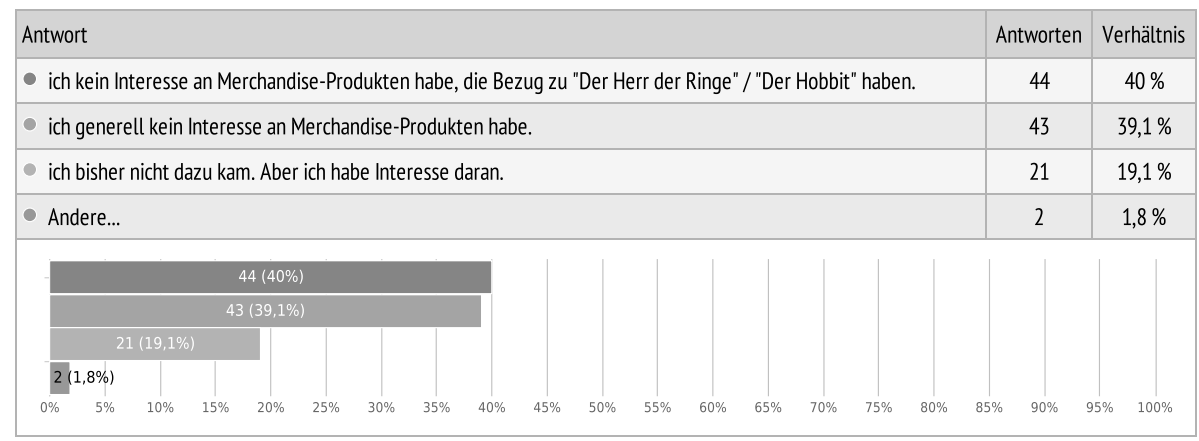

- Ich noch keins gefunden habe dass ich gut fand.

- weil ich zwar die Bücher/Filme mag aber kein Interessen DIESEN Merchandise-Produkten hatte.

\section{Du bist ...}

Einzelwahl, geantwortet 244x, unbeantwortet $439 x$

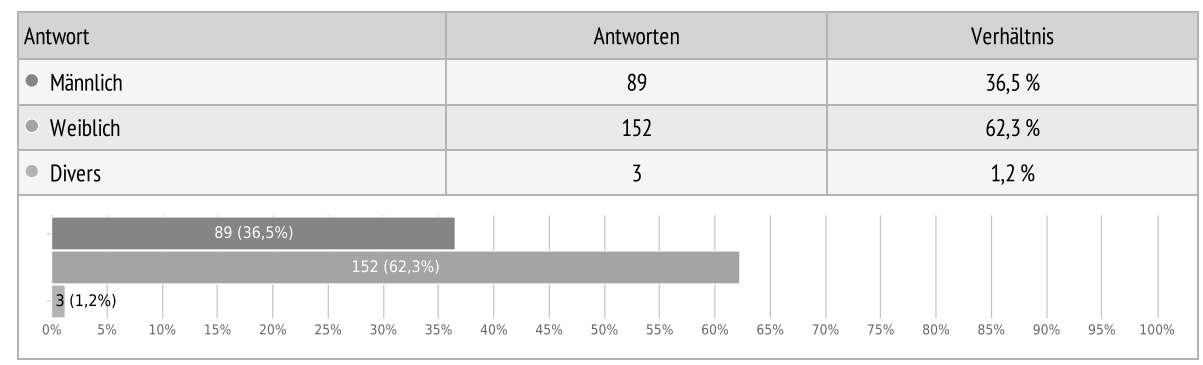




\section{Zu welcher Altersgruppe gehörst du?}

Einzelwahl, geantwortet 244x, unbeantwortet $439 x$

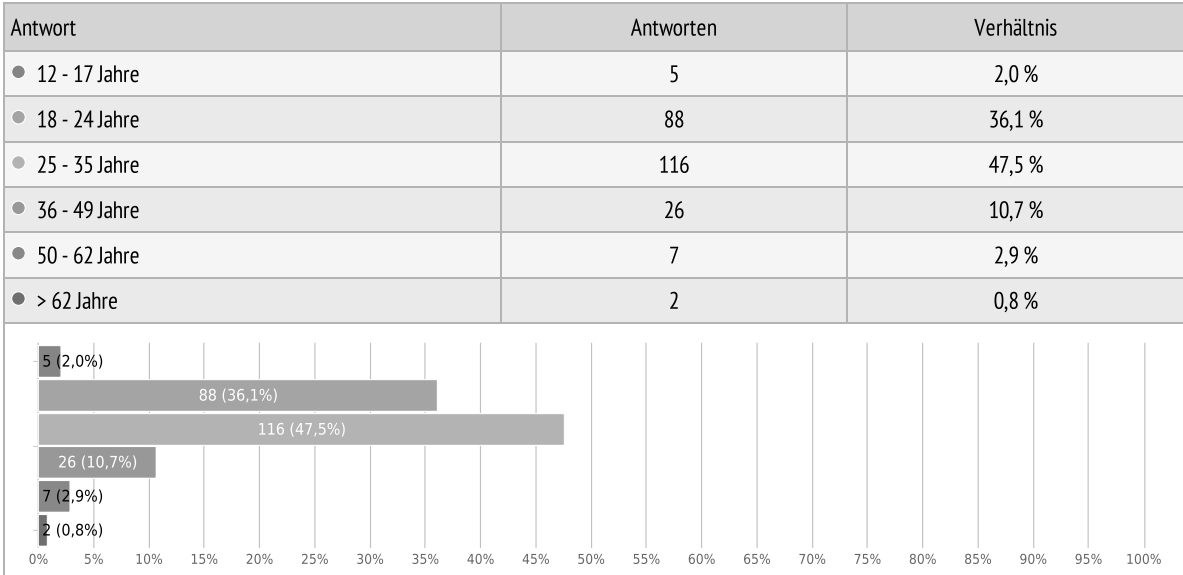

Was ist deine momentane (Haupt-)Berufstätigkeit?

Einzelwahl, geantwortet 244x, unbeantwortet 439x

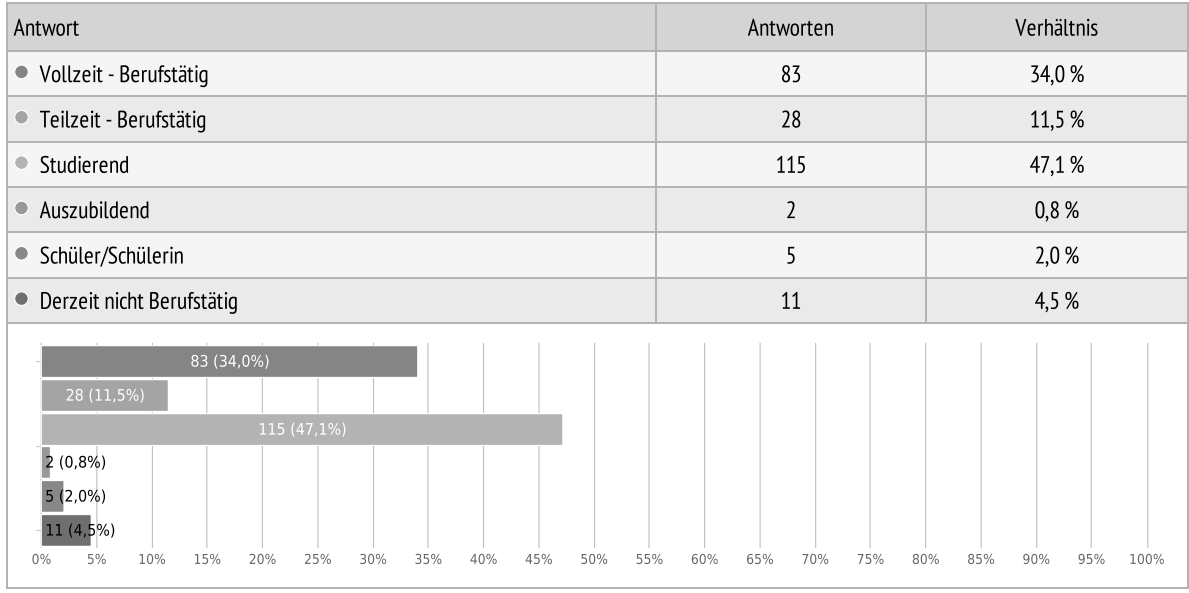




\section{¿survio}

Hast du zuerst die Bücher gelesen oder die Serie geschaut?

Einzelwahl, geantwortet 246x, unbeantwortet $437 x$

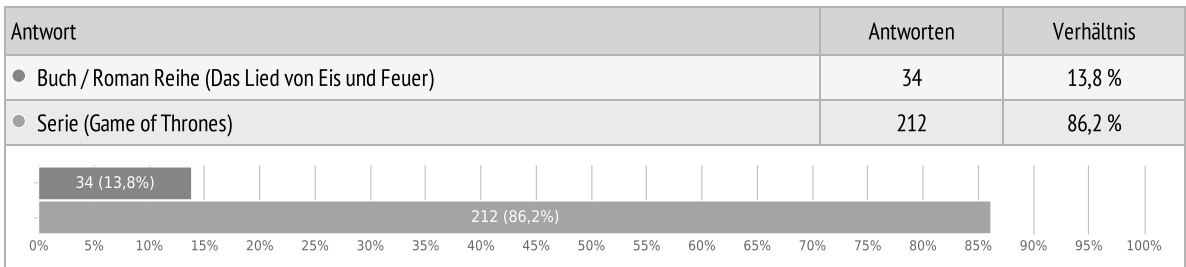

Hast du schon einmal bewusst und aktiv die Serie "Game of Thrones" geschaut? Einzelwahl, geantwortet $34 x$, unbeantwortet 649x

\begin{tabular}{|c|c|c|c|c|c|c|c|c|c|c|c|c|c|c|c|c|c|c|c|}
\hline \multicolumn{5}{|l|}{ Antwort } & \multicolumn{8}{|c|}{ Antworten } & \multicolumn{7}{|c|}{ Verhältnis } \\
\hline - Ja & & & & & \multicolumn{8}{|c|}{32} & \multicolumn{7}{|c|}{$94,1 \%$} \\
\hline Nein & & & & & \multicolumn{8}{|c|}{2} & \multicolumn{7}{|c|}{$5,9 \%$} \\
\hline \multicolumn{20}{|c|}{$32(94,1 \%)$} \\
\hline \multicolumn{20}{|l|}{$2(5,9 \%)$} \\
\hline $0 \% \quad 5 \%$ & $10 \%$ & $15 \%$ & $20 \%$ & $25 \%$ & $30 \%$ & $35 \%$ & $40 \%$ & $45 \%$ & $50 \%$ & $55 \%$ & $60 \%$ & $65 \%$ & $70 \%$ & $75 \%$ & $80 \%$ & $85 \%$ & $90 \%$ & $95 \%$ & $100 \%$ \\
\hline
\end{tabular}

Als du die Serie gesehen hast, wolltest du...

Einzelwahl, geantwortet 32x, unbeantwortet $651 x$

\begin{tabular}{|l|l|c|c|c|c|}
\hline Antwort & Antworten & Verhältnis \\
\hline mehr über die Story und über die Welt von Westeros und deren Charaktere erfahren. & 23 & $71,9 \%$ \\
\hline \\
die selbe Story noch einmal in einer anderen Medien-Form wieder erleben.
\end{tabular}


Nein, weil...

Einzelwahl, geantwortet $2 x$, unbeantwortet $681 x$

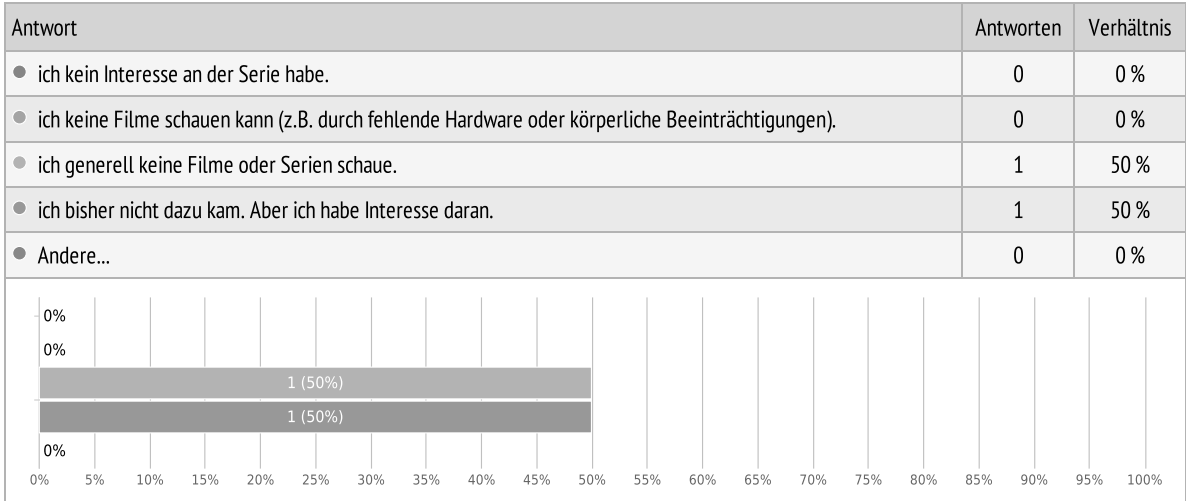

Hast du schon einmal ein Buch gelesen, dessen Story in Westeros stattfindet? Einzelwahl, geantwortet 212x, unbeantwortet $471 x$

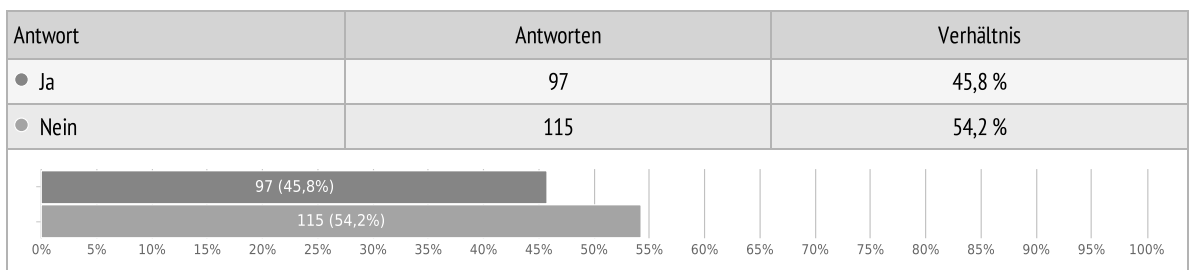




\section{Als ich die Bücher gelesen habe, wollte ich ...}

Einzelwahl, geantwortet 97x, unbeantwortet $586 x$

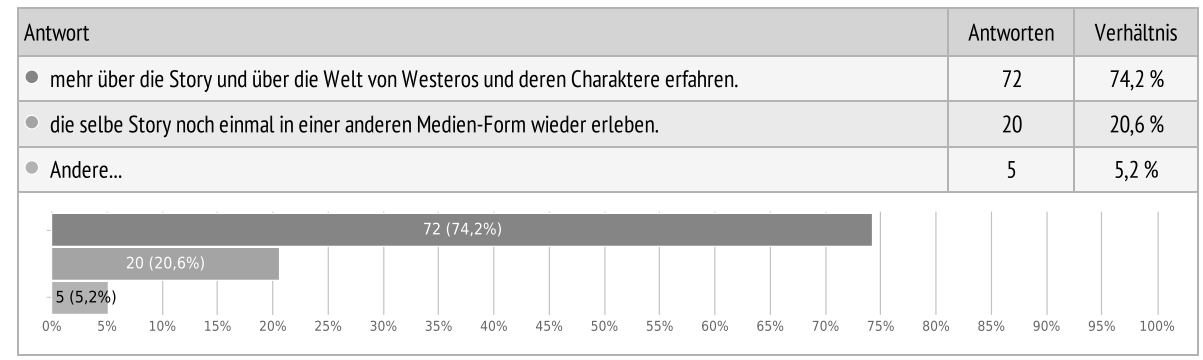

- Das Lied von Eis und Feuer Band eins gelesen,anschließend zur Serie gewechselt.

- Man sollte erst die Bücher lesen

- Wissen wie die Story weitergeht

- Hab ich mir gedacht, dass diese leider echt zäh geschrieben sind

- Ich habe gerade angefangen zu Lese

\section{Nein, weil...}

Einzelwahl, geantwortet 115x, unbeantwortet 568x

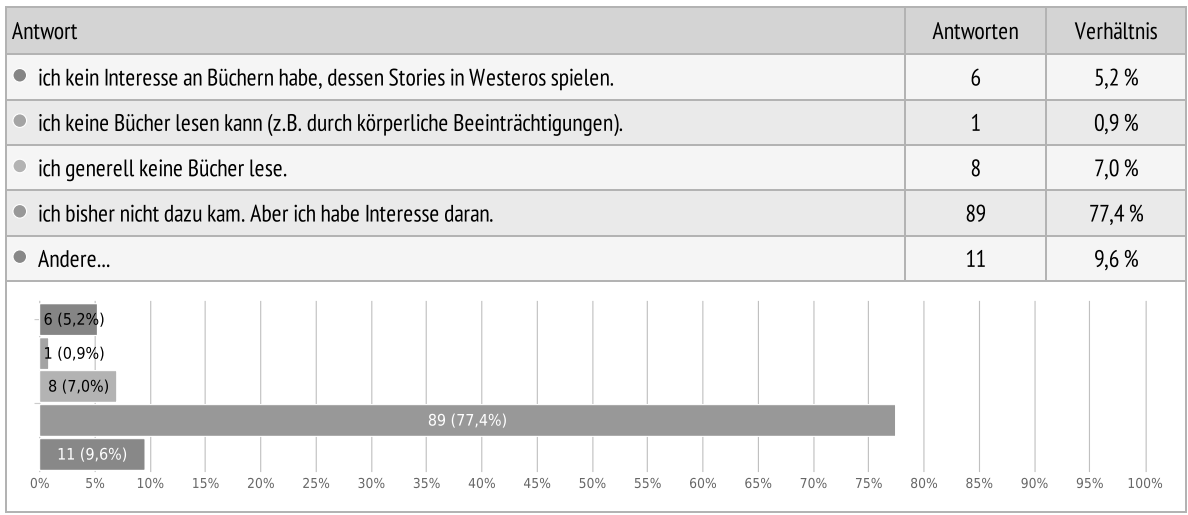

- Ich warte, bis grrm alle Bücher veröffentlicht hat

- Ich habe 2 Seiten angefangen und mochte den Schreibstil überhaupt nicht 
- ich die Serie + Ereignisse jetzt schon kenne, es sehr viel ist

- Normalerweise lese ich zuerst das Buch bevor ich die Serie oder den Film schaue. In diesem Fall habe ich zuerst die Serie geschaut.

ich nur abgeschlossene Reihen lesen möchte, ich warte also noch ab.

- Ich lese keine Fantasyromane

- Ich bin durch Zufall zur Serie gekommen. Da spielten bis dahin die Bücher keine Rolle für mich, auch weil es da noch kein Ende gibt.

- Erstes Buch angefangen, Schreibstil gefiel nicht

- Habe mein Interesse für GOT vor kurzem entdeckt und danach erfahren das es davon Bücher gibt

- Ich lese eher kurze Bücher oder kleinere Bücher Serien

ich ein Buch angefangen habe, aber nicht damit warm werden konnte.

\section{Hast du schon einmal ein Computerspiel gespielt, dessen Story in Westeros stattfindet?}

Einzelwahl, geantwortet 246x, unbeantwortet $437 x$

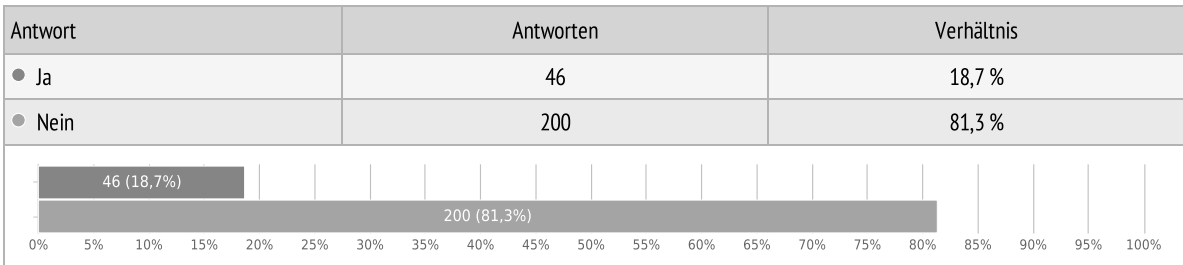

\section{Als ich das Computerspiel gespielt habe, wollte ich...}

Einzelwahl, geantwortet 46x, unbeantwortet 637x

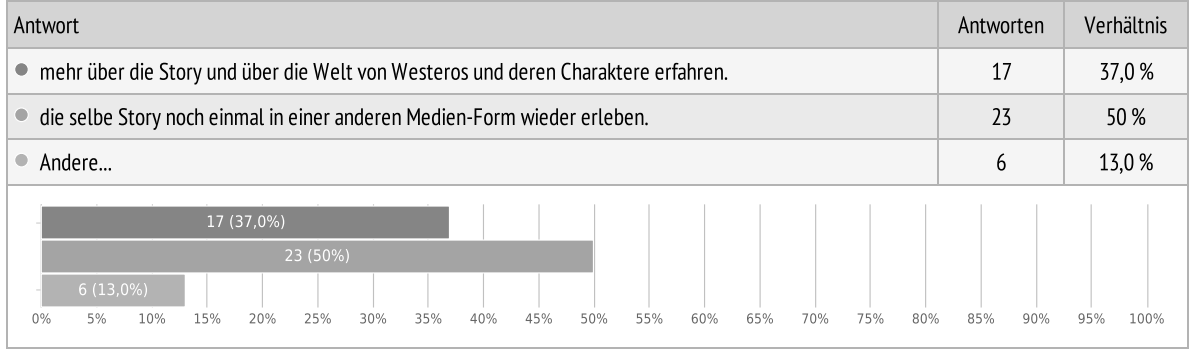

schnell aufhören

- ich war schlicht neugierig wie das Spiel die Story umgesetzt hat.

- nie wieder spielen 


\section{Esurvio}

- Keine Story erleben

- Spaß haben

- Mochte telltale games und fand die thematk got cool

\section{Nein, weil...}

Einzelwahl, geantwortet 200x, unbeantwortet $483 x$

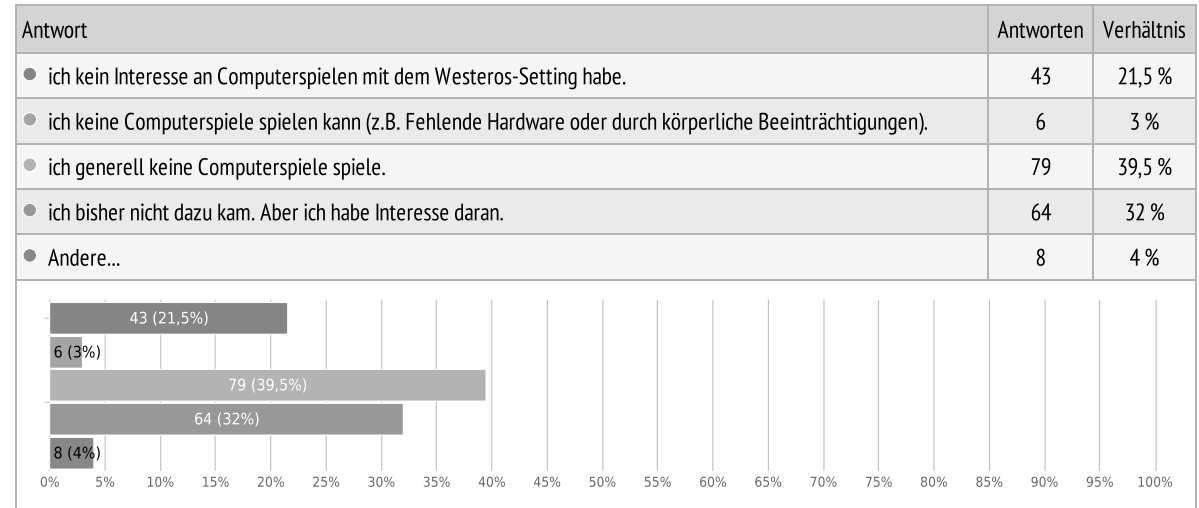

- Mir nicht bewusst ist das es ein Game of Thrones Spiel gibt

- Kein interessantes Spiel bis jetzt von westeros

- Meines Wissens nach gibt es derzeit kein gutes Spiel für Konsolen oder PC im Setting Westeros.

- keins was mich auch gereizt hat

- Keine Zeit dafür habe

- Es gab kein Spiel, dass mir gefallen hat.

- Ich habe kein passendes gefunden

- Ich kenne keine für die ps4 
Hast du schon einmal einen Comic gelesen, dessen Story in Westeros stattfindet? Einzelwahl, geantwortet 246x, unbeantwortet $437 x$

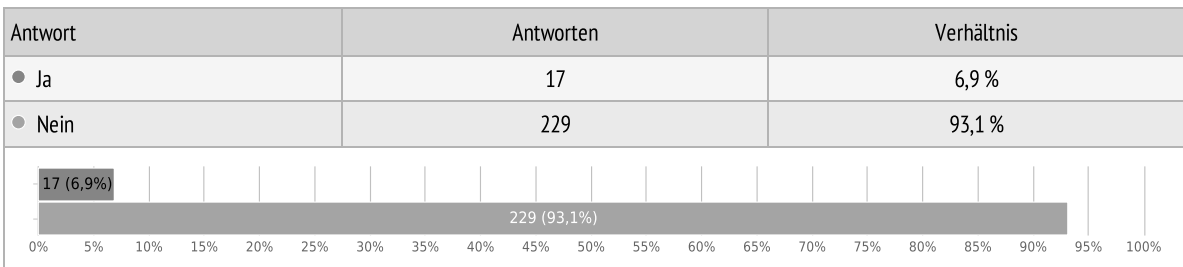

Als ich den Comic gelesen habe, wollte ich ...

Einzelwahl, geantwortet $17 x$, unbeantwortet 666x

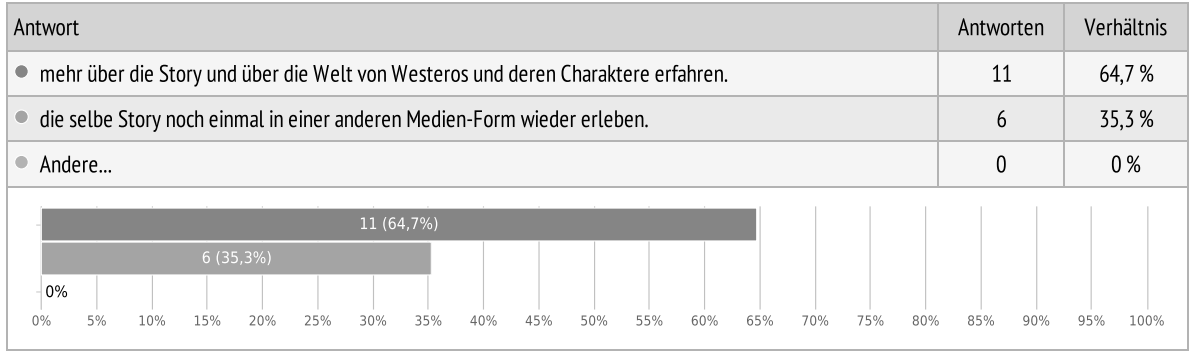




\section{Ésurvio}

\section{Nein, weil...}

Einzelwahl, geantwortet 229x, unbeantwortet $454 x$

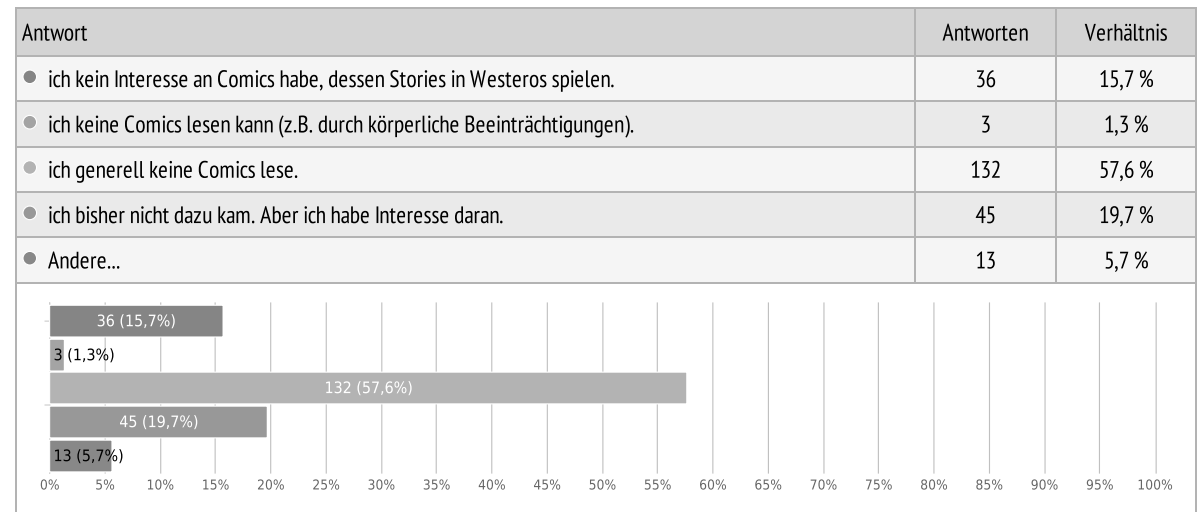

- Ich nicht wusste, dass es Comics dazu gibt

- Keine Zeit und leider nach Arbeit wenig Interesse an Internet

- Das habe ich noch nicht gekannt

- Ich noch nie Comics gesehen habe die in Westeros spielen

- Ich wusste nicht dass es das gibt

- Ich wusste nicht, dass es diese Comics gibt.

- Gibt es einen Comic zu GoT?

Ich es nicht wusste

- Ich wusste nicht das es Comics zu Game of thrones gibt.

- Ich wusste nicht, dass es dazu sogar einen Comic gibt. Mir sind nur die Bücher, Serien und Spiele jeglicher Art dazu bekannt.

- Probe gelesen und nach Büchern und Film brauchte ich die story lein drittes Mal lesen. Aber Comics lese ich generell

- Wusste nicht, dass es das gibt, es besteht Interesse

- Ich wusste nicht, dass es Comics gibt, deren Stories in Westeros spielen. 
Hast du schon einmal eine Webseite oder ein Online-Wiki genutzt, dessen Inhalte sich auf die Welt von Westeros bzw. Essos beziehen?

Einzelwahl, geantwortet 246x, unbeantwortet $437 x$

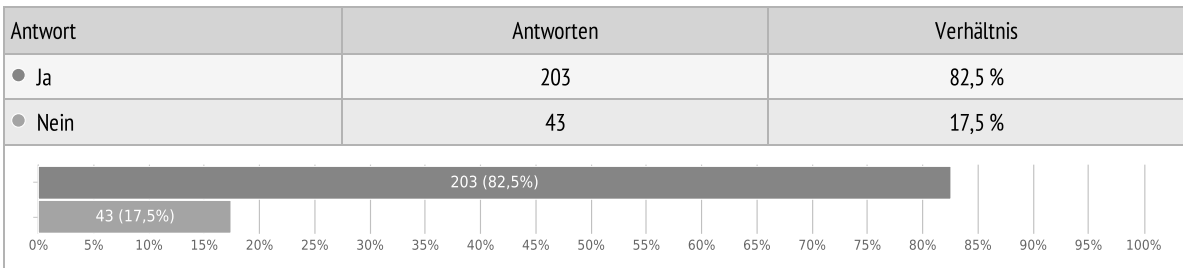

Als ich die Webseite bzw. das Online-Wiki besucht habe, wollte ich ... Einzelwahl, geantwortet 203x, unbeantwortet 480x

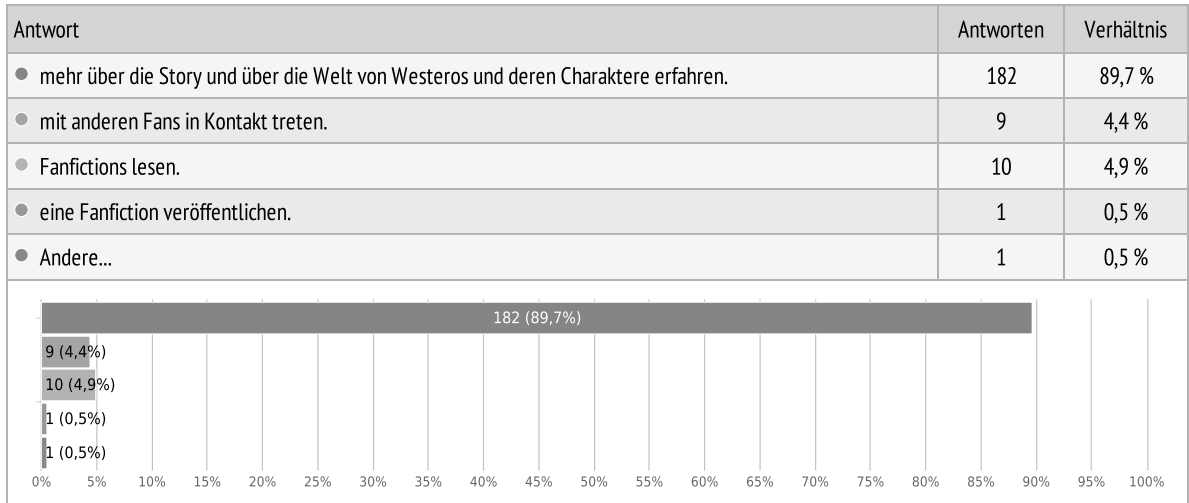

- Fakten aus der Serie nachlesen 


\section{Elsurvio}

Nein, weil...

Einzelwahl, geantwortet 43x, unbeantwortet 640x

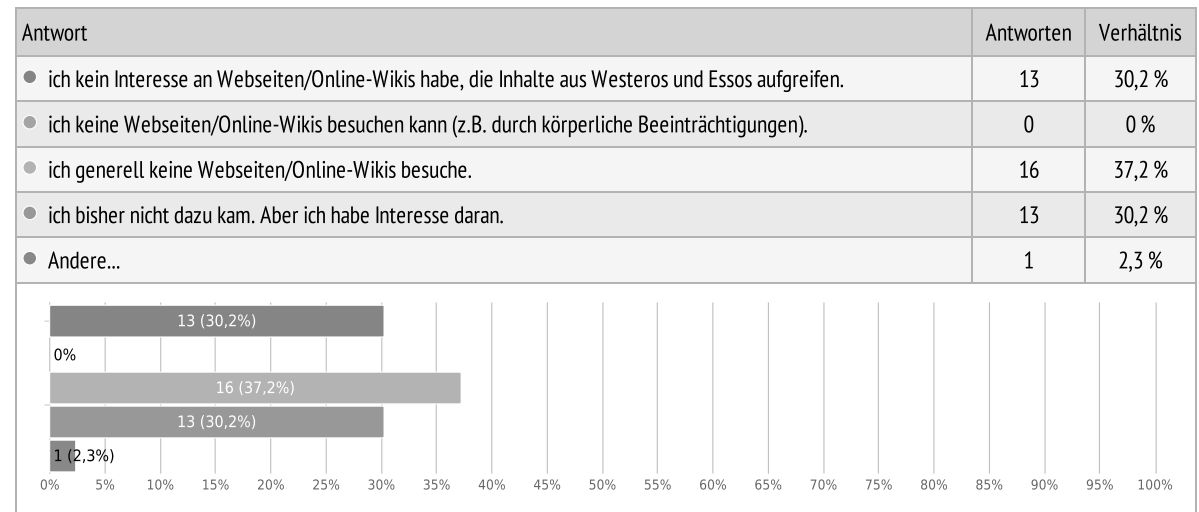

- Bisher hatte ich kein Bedürfnis dazu.

\section{Hast du schon einmal Merchandise-Produkte mit Bezug zu "Game of Thrones" gekauft?}

Einzelwahl, geantwortet 246x, unbeantwortet $437 x$

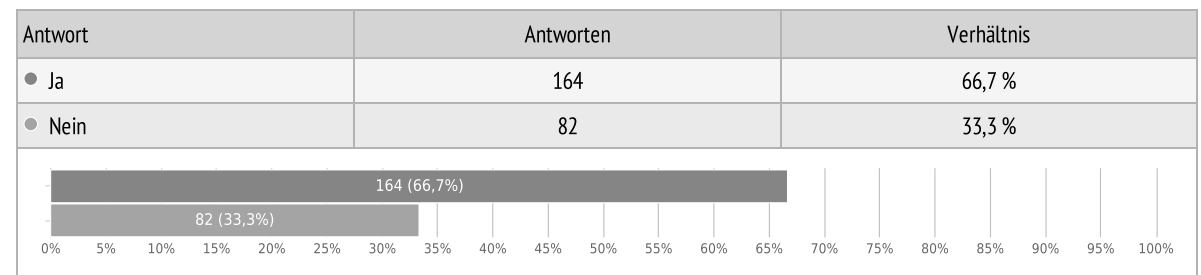




\section{Als ich diese Merchandise-Produkte gekauft habe, wollte ich...}

Einzelwahl, geantwortet 164x, unbeantwortet 519x

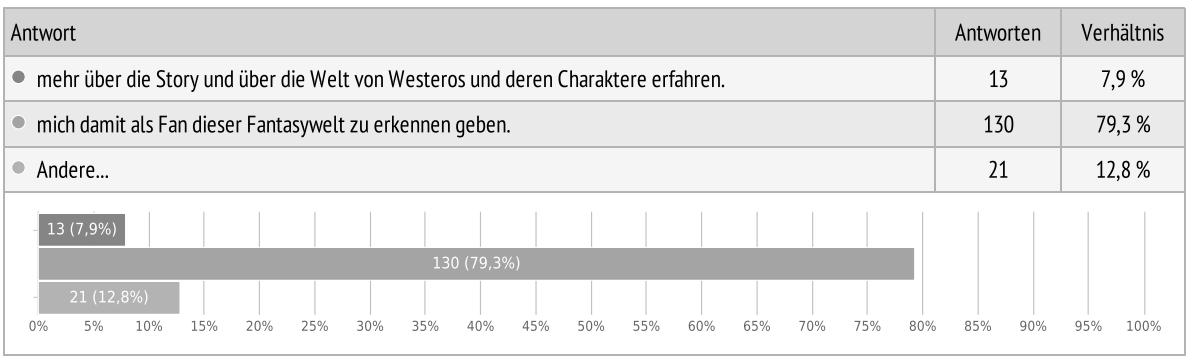

- Das Spielkonzept hat mich überzeugt. Die Einbettung in Westeros war ein Bonus

- Das Kochbuch nutzen/Elemente aus dem fandom in meinem Alltag integrieren wollte

- Es waren zwei T-shirt

- (2x) Geschenk

- Als Geschenke für einen Fan

- Ich ein gutes Brettspiel spielen wollte, das zudem einen geliebten Hintergrund hat

- GOT Risiko (Tabletop) ist gut umgesetzt und macht einfach Spaß.

- Geschenk für Freunde

- Weil es mir gefällt

- Als Geschenk genommen

- Ich wollte sie einfach gerne haben, weil ich es witzig finde

- Was erwerben, was ggf später an Wert gewinnt

- meinen Alltag mit der Präsenz dieser Serie aufheitern.

- Geschenk an meinen Freund

- verschenken

- War ein Geschenk

- Erinnerungen an die Serie und weil mir die Artikel gefallen haben

- Cooles Designe

- Ich fand es einfach schön

- Es einfach haben 


\section{İsurvio}

\section{Nein, weil...}

Einzelwahl, geantwortet 82x, unbeantwortet $601 x$

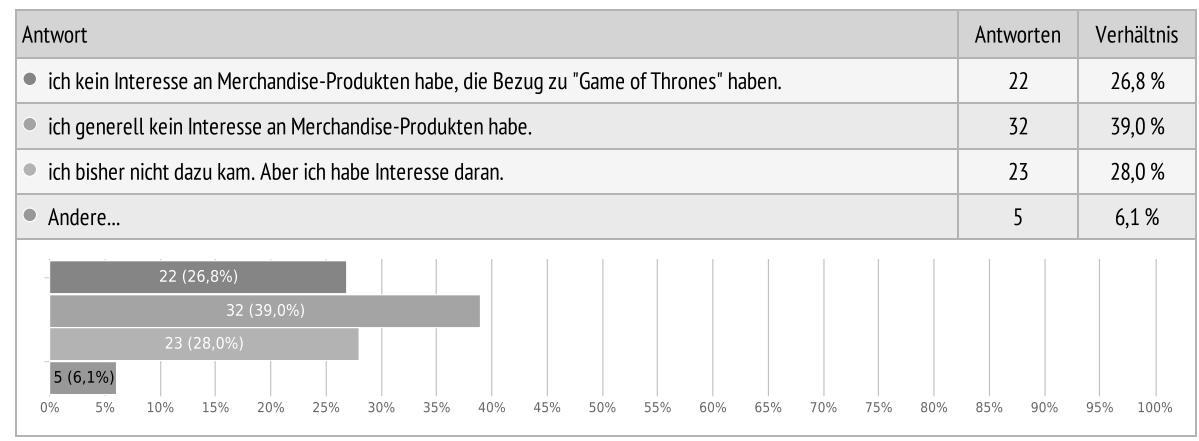

- ich generell wenig bzw. selten Dinge kaufe, die ich nicht wirklich brauche (wie z.B. Essen).

- Zu teuer

- Habe merch geschenkt bekommen

- nur geschenkt bekommen (und sich darüber gefreut), aber nie selbst gekauft

- Ich hab mal ein GoT-Fanpaket gewonnen, aber keine Merchandise-Produkte selbst gekauft.

\section{Du bist ...}

Einzelwahl, geantwortet 246x, unbeantwortet $437 x$

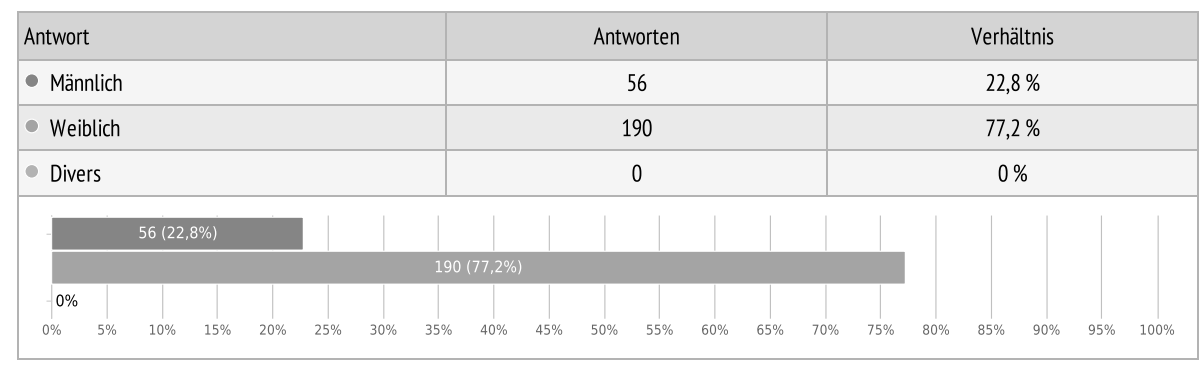




\section{Zu welcher Altersgruppe gehörst du?}

Einzelwahl, geantwortet 246x, unbeantwortet $437 x$

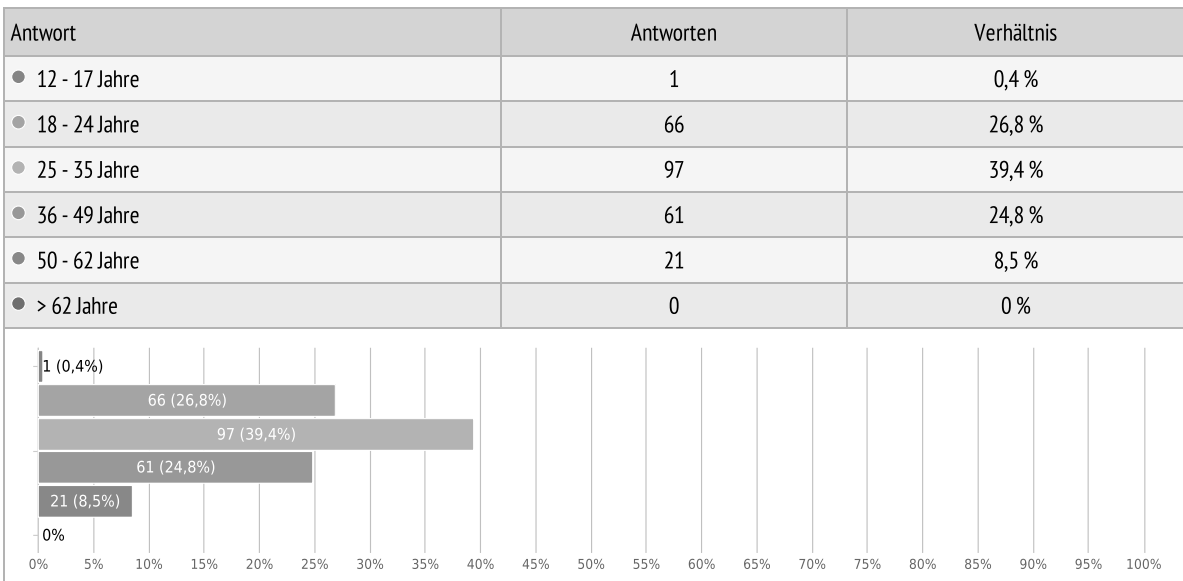

Was ist deine momentane (Haupt-)Berufstätigkeit?

Einzelwahl, geantwortet 246x, unbeantwortet $437 x$

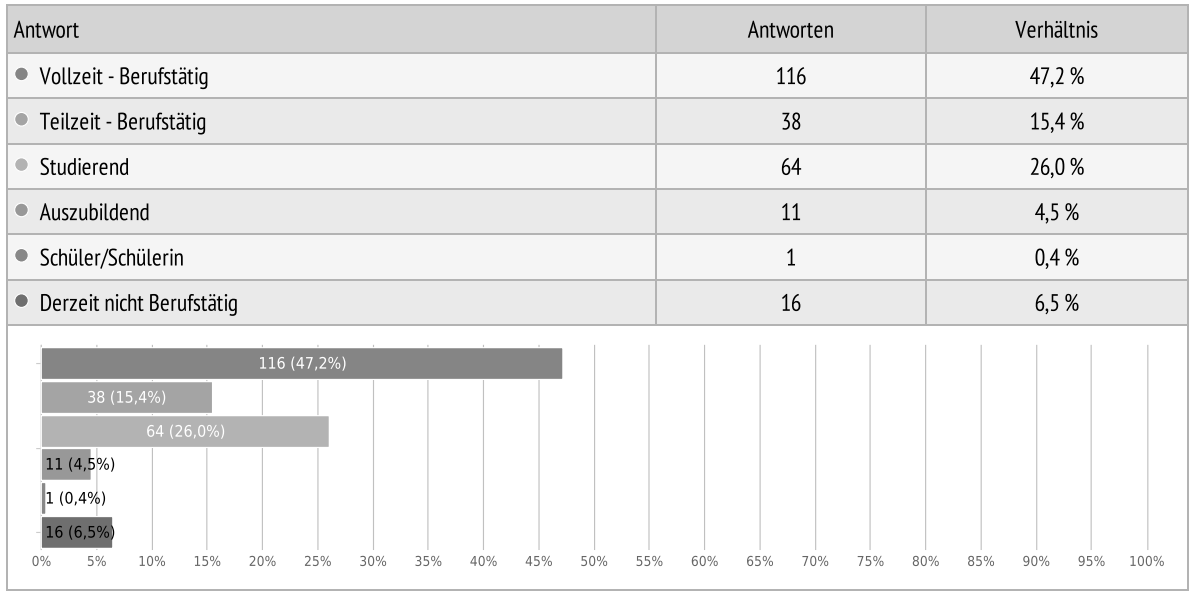




\section{Istsurvio}

\section{Hast du zuerst die Bücher gelesen oder die Spiele gespielt?}

Einzelwahl, geantwortet 181x, unbeantwortet $502 x$

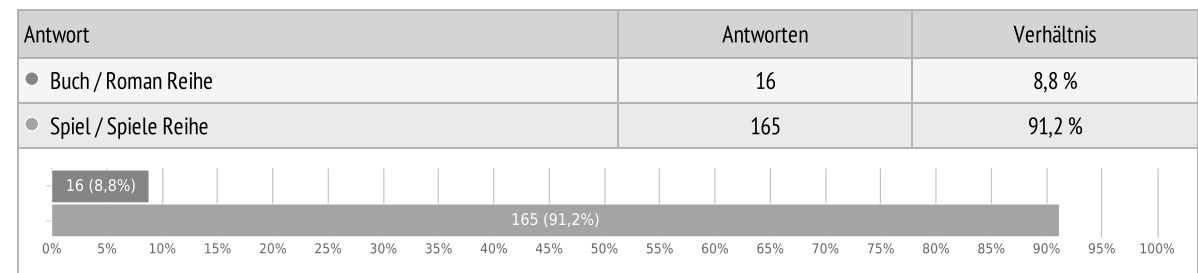

Hast du schon einmal einen Spiel der "The Witcher" - Spielereihe gespielt? Einzelwahl, geantwortet 16x, unbeantwortet 667x

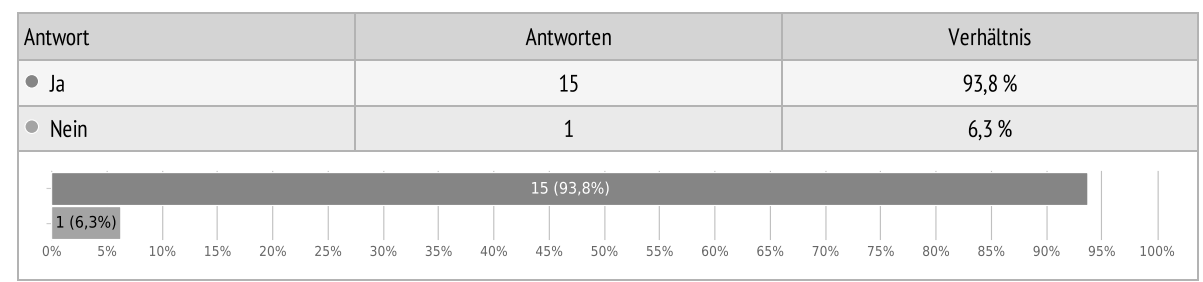

Als ich die Computerspiele gespielt habe, wollte ich...

Einzelwahl, geantwortet 15x, unbeantwortet 668x

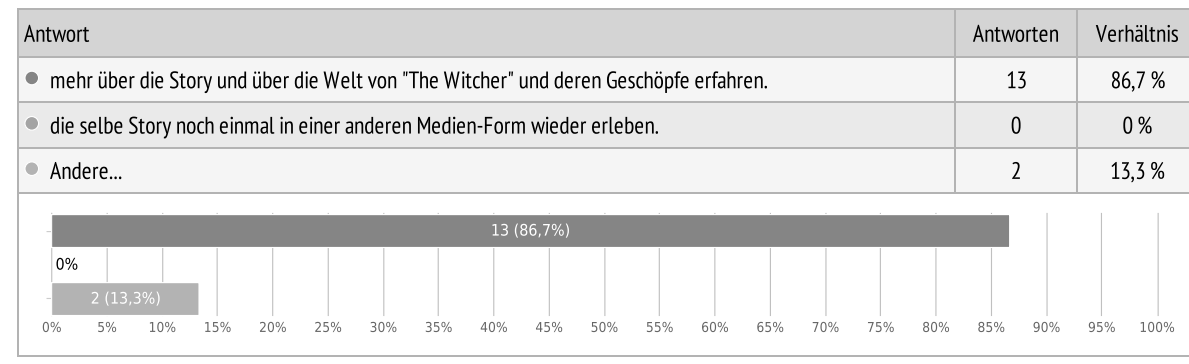

- die Interpretation im Medium Spiel erfahren

- Die Kreativität der Entwickler erleben und deren Adaption der Story kennenlernen. 
Nein, weil...

Einzelwahl, geantwortet $1 x$, unbeantwortet 682x

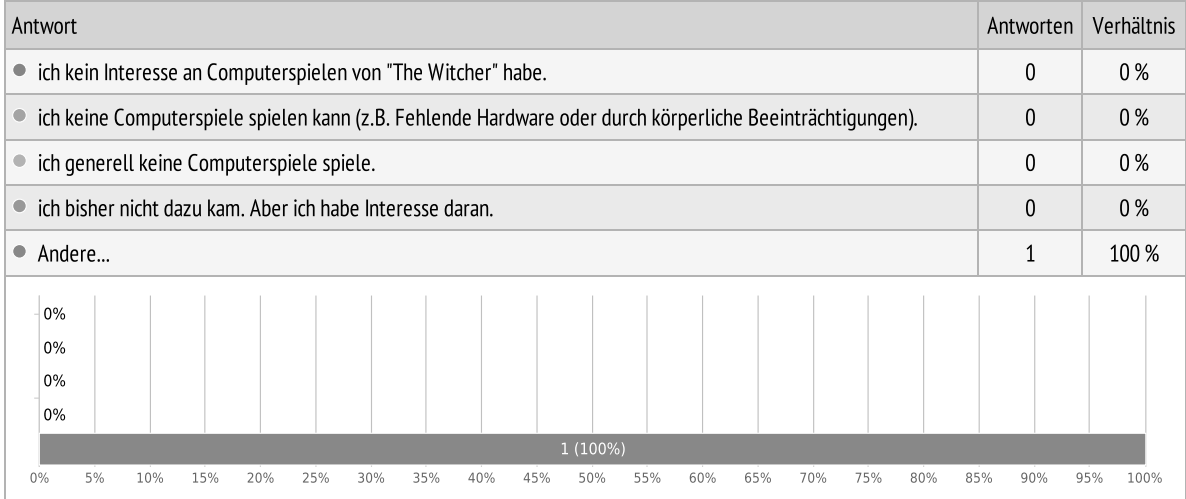

- Ich die Spiele als Let's Play geschaut habe.

Hast du schon einmal ein Buch gelesen, dessen Story in der Welt von "The Witcher" stattfindet?

Einzelwahl, geantwortet 165x, unbeantwortet 518x

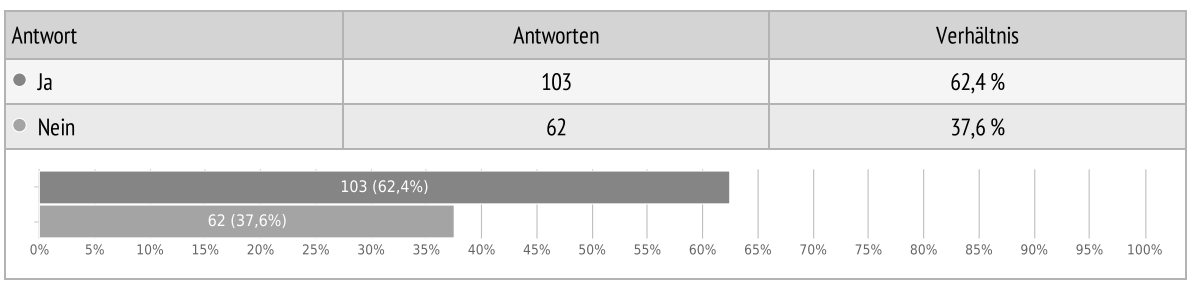




\section{¿survio}

\section{Als ich die Bücher gelesen habe, wollte ich ...}

Einzelwahl, geantwortet 103x, unbeantwortet 580x

\begin{tabular}{|l|l|c|c|c|c|c|c|c|c|}
\hline Antwort & Antworten & Verhältnis \\
\hline mehr über die Story und über die Welt von "The Witcher" und deren Geschöpfe erfahren. & 95 & $92,2 \%$ \\
\hline \\
\hline
\end{tabular}

Nein, weil...

Einzelwahl, geantwortet $62 x$, unbeantwortet $621 x$

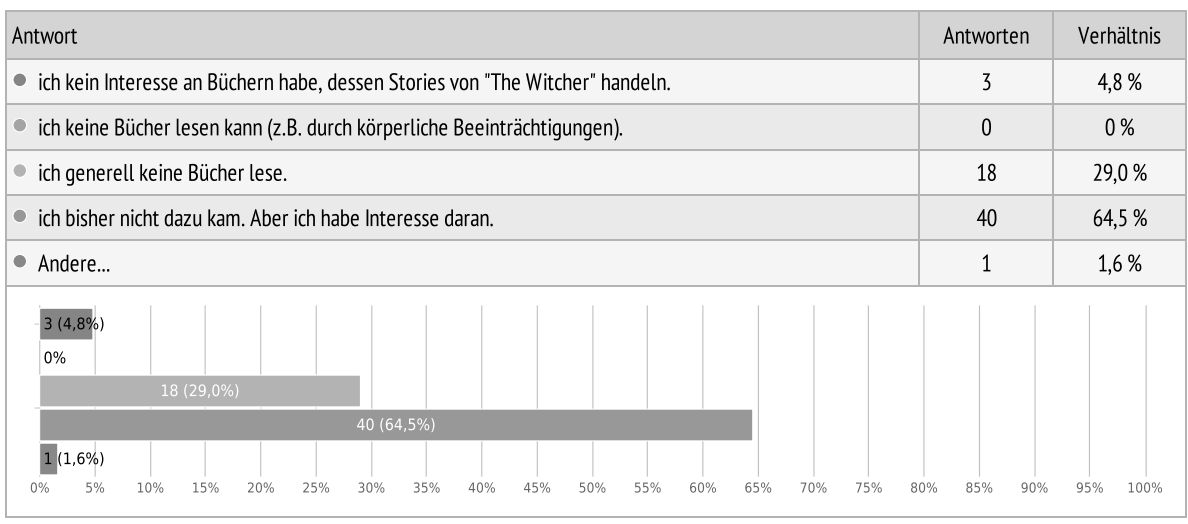

- Ich sonst nur Sachbücher lese 
Hast du schon einmal einen Film oder eine Serie gesehen, dessen Plot sich um "Geralt von Riva" dreht?

Einzelwahl, geantwortet 181x, unbeantwortet 502x

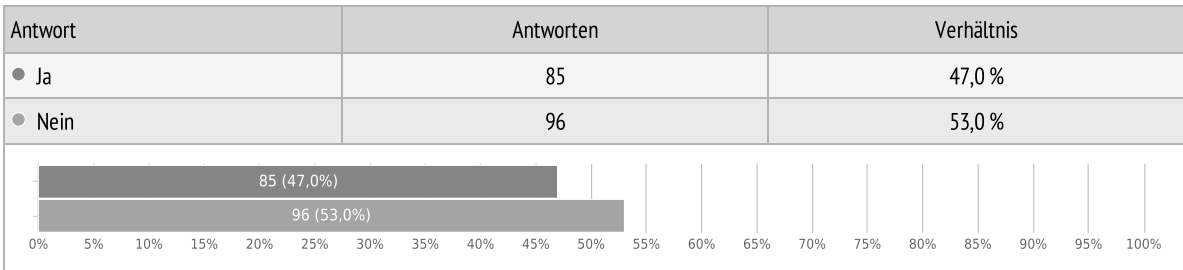

Als du die Filme/Serie geschaut hast, wolltest du...

Einzelwahl, geantwortet $85 x$, unbeantwortet $598 x$

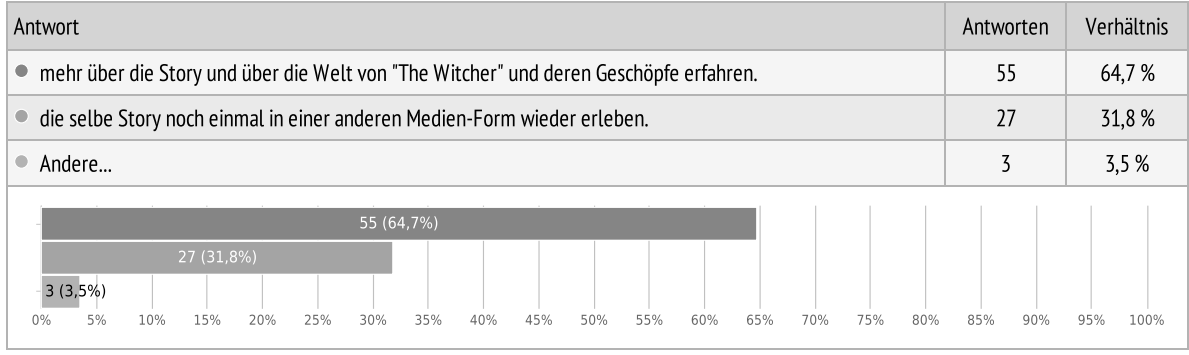

- Beide Antworten passen und ich kann mich nicht entscheiden

- Nee der Film war nicht gut

- Die Filme waren qualitativ nicht so gut. Da, ich aber die Bücher und Spiele vorher schon kannte, fand ich The Witcher 3 immer noch geil. 


\section{Elsurvio}

\section{Nein, weil...}

Einzelwahl, geantwortet 96x, unbeantwortet $587 x$

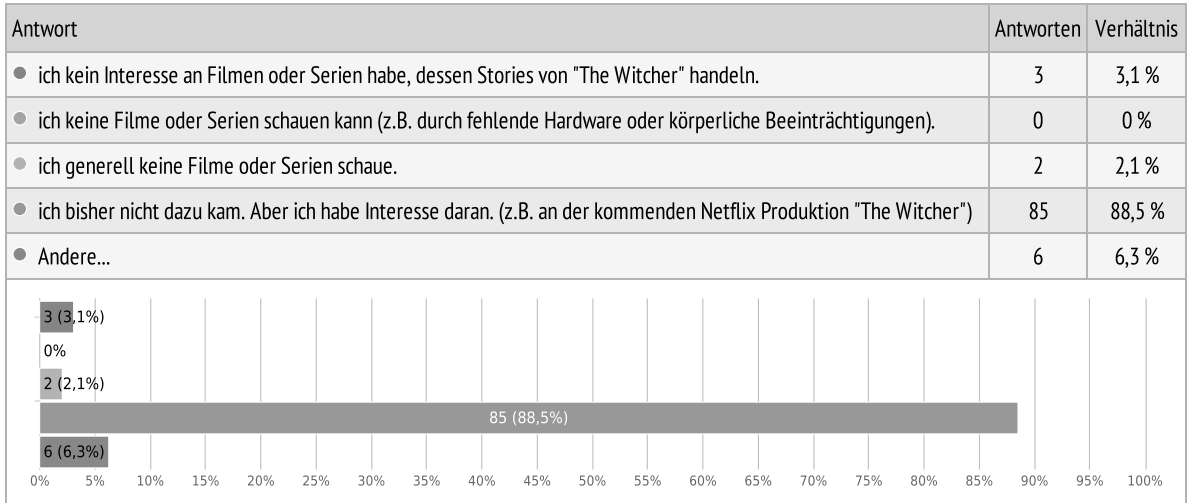

- Die Kritiken zu bisherigen Filmen haben mich eher abgeschreckt und auch was ich von der Serie bislang gesehen habe, überzeugt mich nicht unbedingt.

- Besetzung der Charaktere sagt mir nicht zu. Werde mir die Serie wohl anschauen, wenn viel positives Feedback ausgesprochen wird.

-...es bis dato noch keine Filme/Serien gibt, die der Welt von "The Witcher" gerecht werden. Kommende Serie (Netflix) werde ich mir definitiv anschauen

- Ich absolut unzufrieden mit dem Cast bin und deshalb auf keinen Fall diese Serie anschauen werde

- Die Serie kommt erst noch auf netflix. Sobald sie verfügbar ist, werde ich sie definitiv ansehen.

- schlechte Besetzung. Man muss nicht immer alles verfilmen.

\section{Hast du schon einmal einen Comic gelesen, dessen Story von "Geralt von Riva" handelt?}

Einzelwahl, geantwortet 181x, unbeantwortet 502x

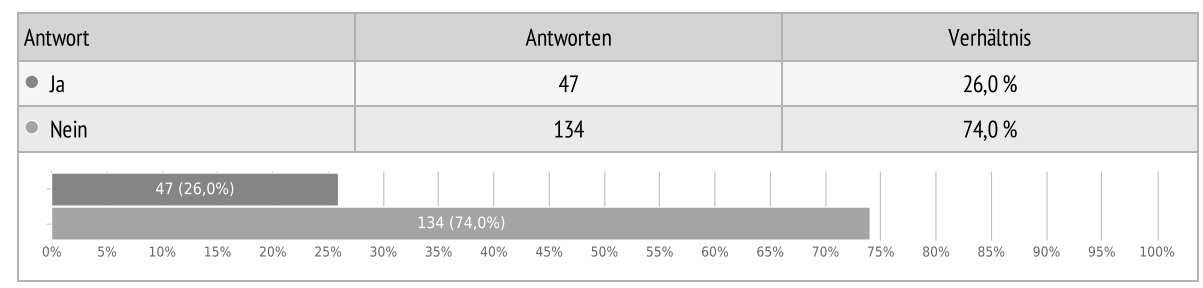




\section{Als ich den Comic gelesen habe, wollte ich ...}

Einzelwahl, geantwortet $47 x$, unbeantwortet $636 x$

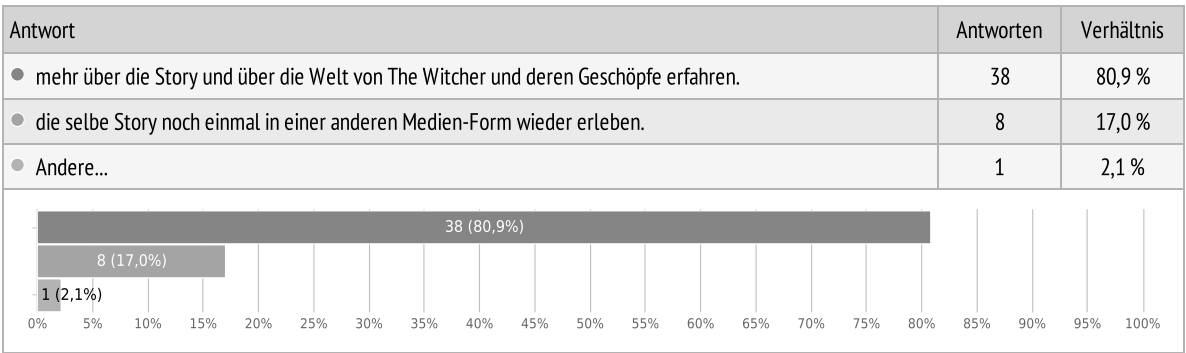

- Einfach noch länger in dem Universum verweilen und dabei neue Inhalte kennenlernen

\section{Nein, weil...}

Einzelwahl, geantwortet 134x, unbeantwortet 549x

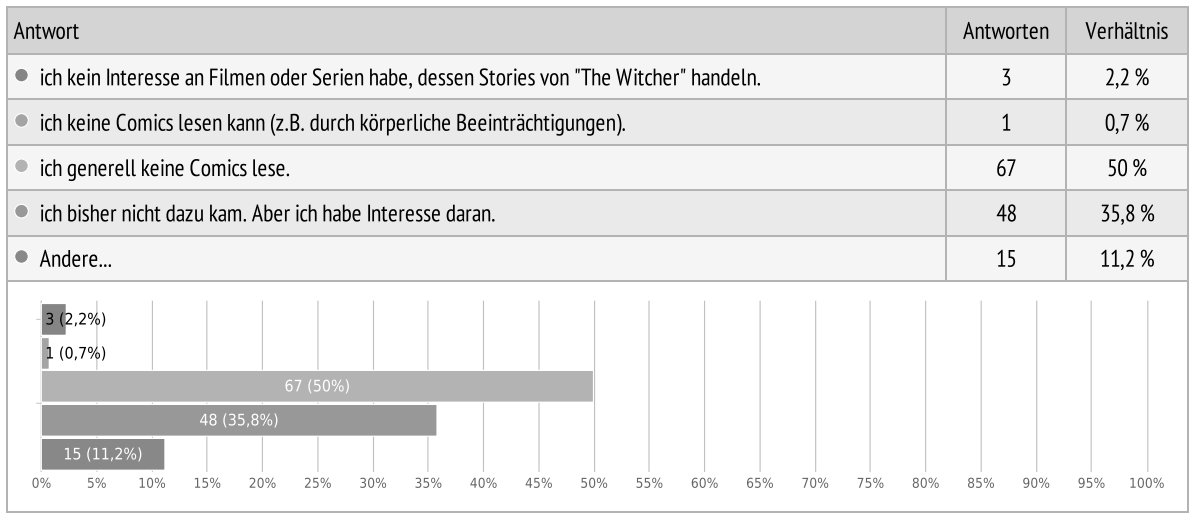

\footnotetext{
- Ich nicht wusste, dass es diese gibt

- Davon nichts wusste

- Ich nicht wusste das es Comics gibt.

- Ich nicht wusste, dass es Comics zum Witcher-Universum gab.

- ich nicht wusste das es Comics gibt

- Ich nicht weiß ob es Comics dazu gibt.

- Ich nicht wusste das es einen Comic gibt
} 


\section{¿survio}

- Wusste nichts von der Existenz der Comics und werde gleich mal googeln

- Ich nicht wusste das es dazu einen Comic gibt.

- Ich nicht wusste das es von Witcher Comics gibt

- Kannte ich gar nicht

- Wusste nicht, dass es sowas gibt

- Wusste nicht das es diese gibt

- Wußte nicht, daß es diesen Comic gibt

- ich den Zeichenstil der Comics nicht mag.

Hast du schon einmal eine Webseite oder ein Online-Wiki genutzt, dessen Inhalte sich auf die Welt von "The Witcher" bezieht?

Einzelwahl, geantwortet $181 x$, unbeantwortet $502 x$

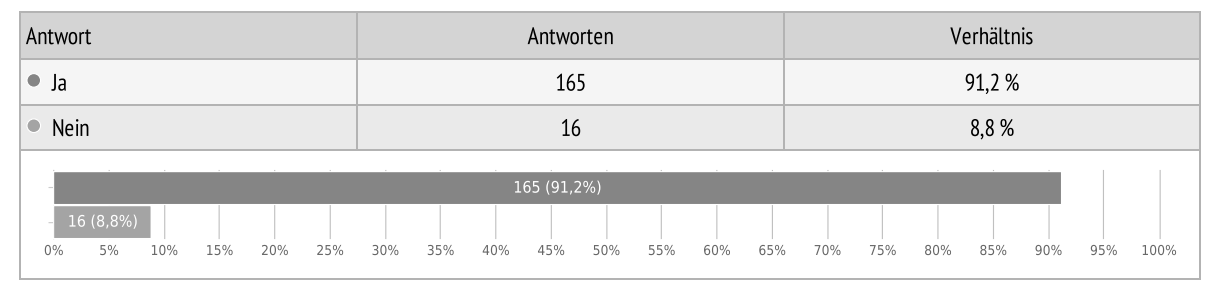

Als ich die Webseite bzw. das Online-Wiki besucht habe, wollte ich ... Einzelwahl, geantwortet 165x, unbeantwortet 518x

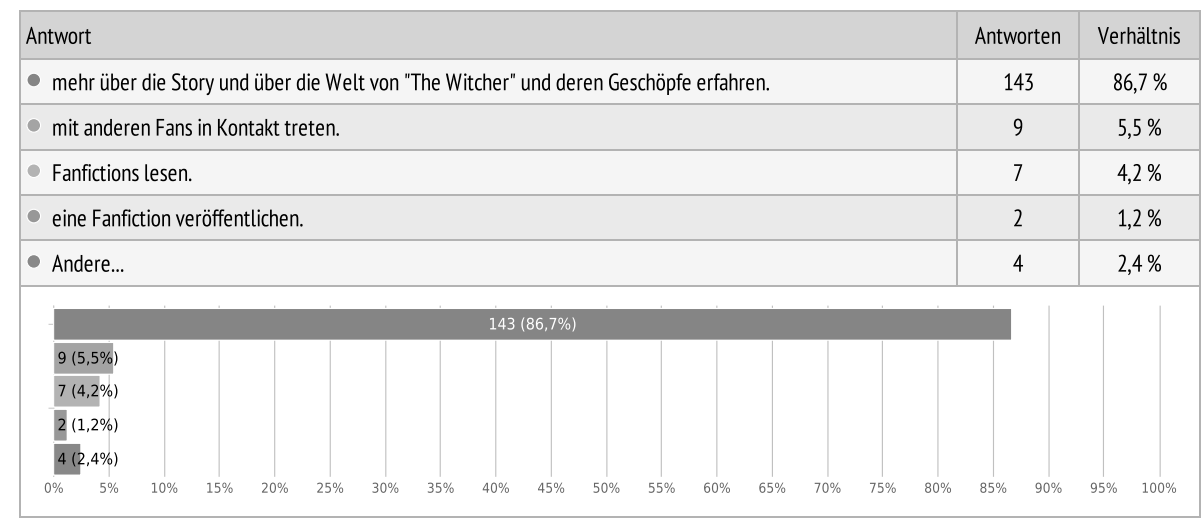




\section{Estsurvio}

- Hintergründe und Walkthroughs zum Spiel erfahren

- Wiki benutz um Informationen zu einer Rüstung im Spiel zu erhalten

- Weil ich "festgesteckt" habe

- Ich hatte im Rahmen meines Studiums eine Website erstellt, welche über "The Witcher 3" handelte.

\section{Nein, weil...}

Einzelwahl, geantwortet 16x, unbeantwortet 667x

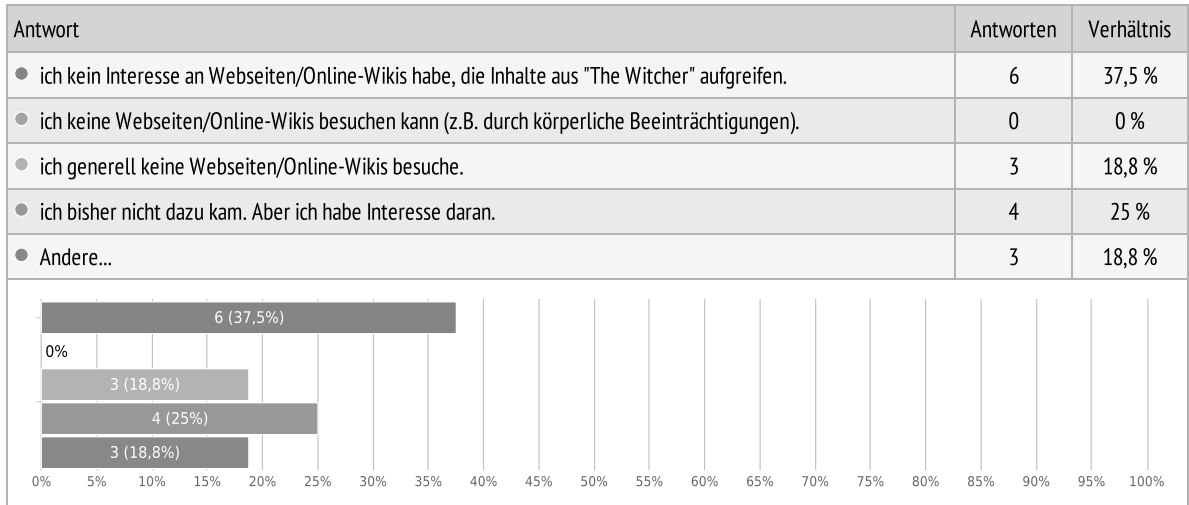

- Es nicht notwendig gewesen ist

- Ich will das spiel durchspielen ohne spoiler, und die rätsel selebr lösen

- mir die Informationen aus den Romanen zur Bildung einer Meinung über Geralt von Riva, bzw. die Welt in der er lebt, reicht...

\section{Hast du schon einmal Merchandise-Produkte mit Bezug zu "The Witcher" gekauft?}

Einzelwahl, geantwortet 181x, unbeantwortet $502 x$

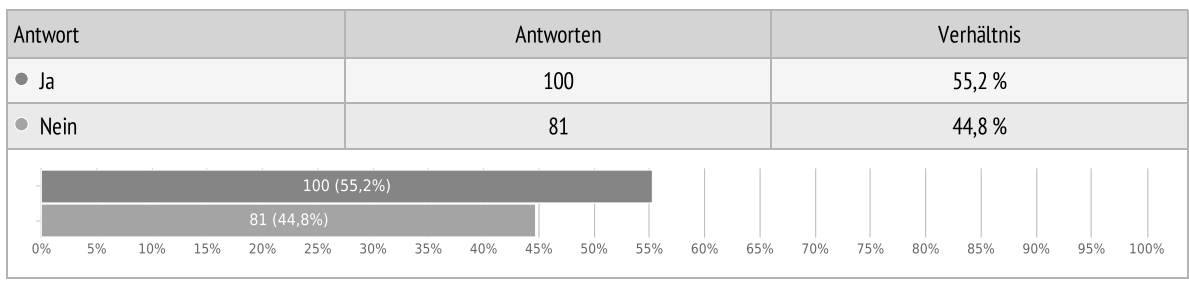




\section{Als ich diese Merchandise-Produkte gekauft habe, wollte ich...}

Einzelwahl, geantwortet 100x, unbeantwortet $583 x$

\begin{tabular}{|l|l|l|l|l|l|}
\hline Antwort & Antworten & Verhältnis \\
\hline mehr über die Story und über die Welt von The Witcher und deren Geschöpfe erfahren. & 15 & $15 \%$ \\
\hline \\
mich damit als Fan dieser Fantasywelt zu erkennen geben.
\end{tabular}

- Sie haben, besitzen, sammeln und mich daran erfreuen

- Als Deko

- Weil ich mich als fan der Witcher-Reihe zu erkennen geben wollte und das Witcher-Universum liebe.

- Das Merch gefiel mir

ich fands geil und finde es immernoch geil. Witcher hin oder her.

- CD Projekt Red Unterstützen

- Mein Zimmer dekorieren / Meinen Arm mit einem Tattoo davon schmücken

\section{Nein, weil...}

Einzelwahl, geantwortet $81 x$, unbeantwortet $602 x$

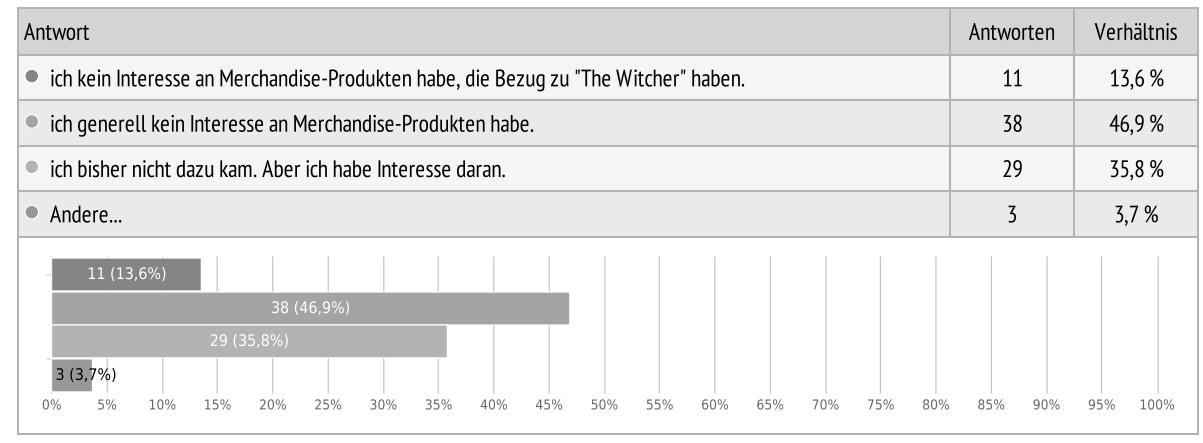

- ich bisher noch nichts Ansprechendes gefunden habe.

- mir das alles zu teuer ist 
- Ich es gewonnen habe.

Du bist ...

Einzelwahl, geantwortet 181x, unbeantwortet $502 x$

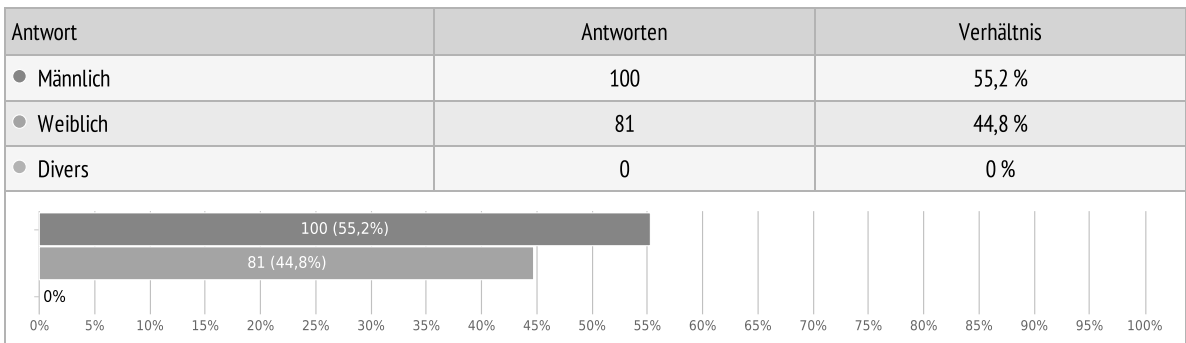

\section{Zu welcher Altersgruppe gehörst du?}

Einzelwahl, geantwortet 181x, unbeantwortet $502 x$

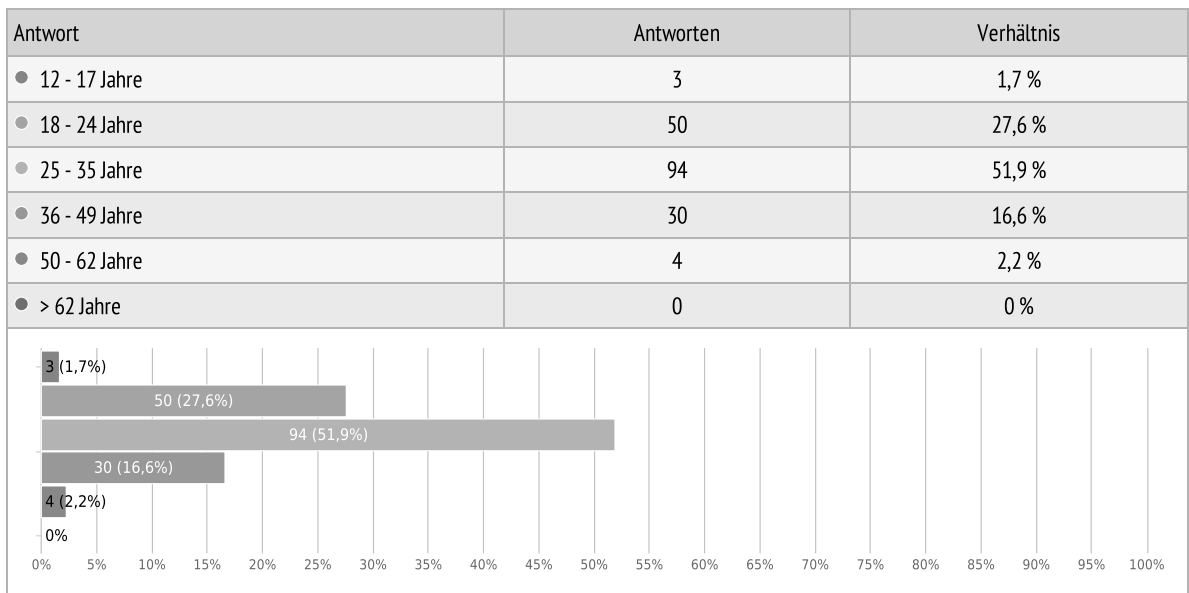




\section{¿survio}

Was ist deine momentane (Haupt-)Berufstätigkeit?

Einzelwahl, geantwortet 181x, unbeantwortet $502 x$

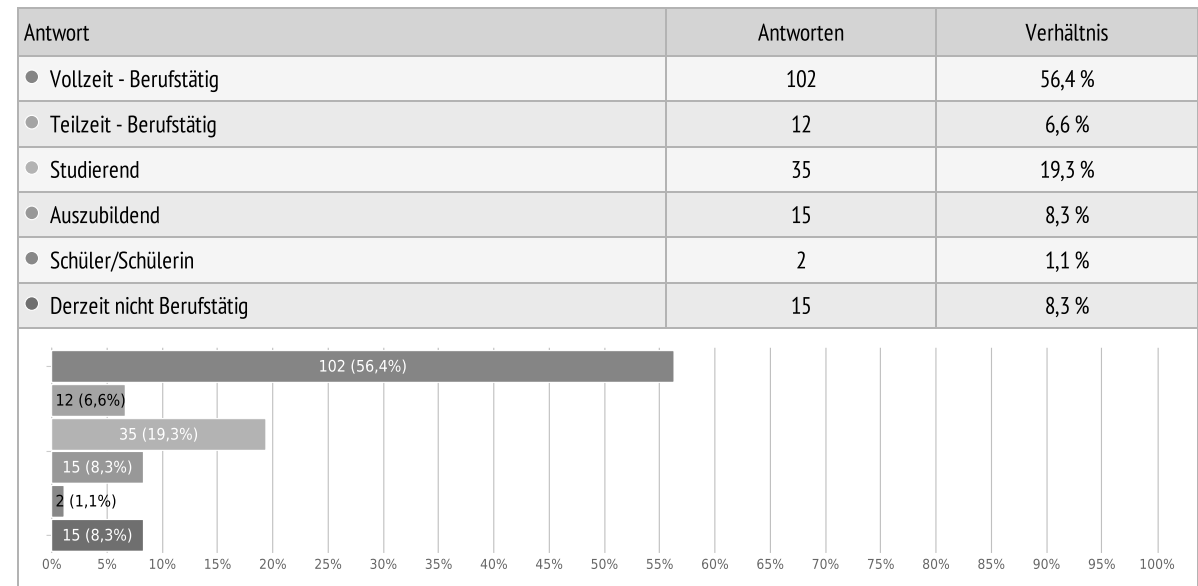

Willst du an unserem Gewinnspiel teilnehmen?

Einzelwahl, geantwortet $671 x$, unbeantwortet $12 x$

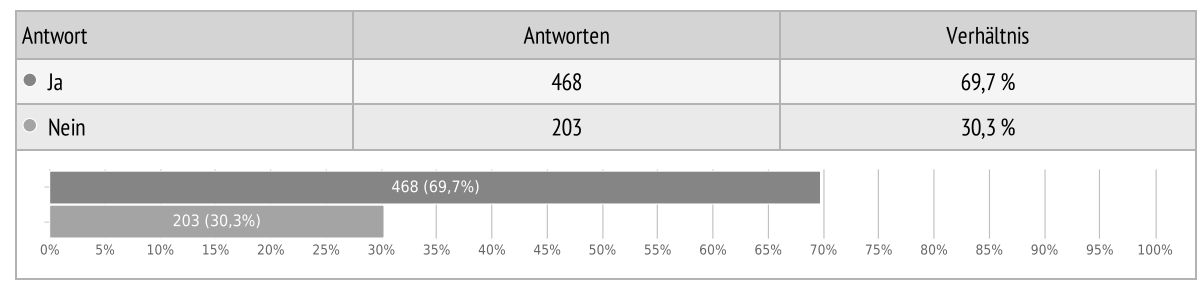

Wir brauchen nur noch deine E-Mail Adresse!

Text Frage, geantwortet $468 x$, unbeantwortet $215 x$

\footnotetext{
- n.abunada@outlook.de

- lukas_kurtze@web.de

- david.richter3@gmx.de

- maximilian.jahr@gmx.de
} 


\section{Umfrage-Einstellungen}

Fragen pro Seite

Mehrere

Erlaube mehrere Einsendungen?

Zurückkehren zur vorherigen Fragen erlauben?

(6) Frage-Nummern anzeigen?

Fragen-Reihenfolge zufällig einordnen?

Fortschrittsanzeige in Umfrage anzeigen?

E-Mail-Benachrichtigung bei beantworteten Umfrage?

Passwortschutz?

IP-Beschränkung? 


\section{Ejsurvio}

Anhang: Umfrage

Konsum von Fantasy Medien

Guten Tag,

bitte widme dieser Umfrage doch ein paar Minuten deiner Zeit.

Am Ende der Umfrage können Sie an einem Gewinnspiel teilnehmen um einen Amazon-Gutschein im Wert von $50 €$ zu gewinnen!

Du Umfrage findet im Rahmen einer Masterarbeit für die HTWK Leipzig statt!

Diese Umfrage wird anhand eines von drei kommerziellen Fantasy Beispielen durchgeführt.

Die Beispiele sind:

Der Herr der Ring / Der Hobbit

The Witcher

Game of Thrones / Das Lied von Eis und Feuer

Bitte gib an, wie viele von den drei Beispielen du bereits bewusst medial konsumiert hast? Fragesupport: Wählen Sie eine Antwort
$\bigcirc$ von 3
O 1 von 3
O 2 von 3
3 von 3

Wenn du keines der Beispiele konsumiert hast, ist die Umfrage für dich beendet. Vielen Dank für deine Zeit und Engagement!

Bitte wähle die Fantasywelt aus, mit der du dich am MEISTEN beschäftigt hast Fragesupport: Wählen Sie eine Antwort
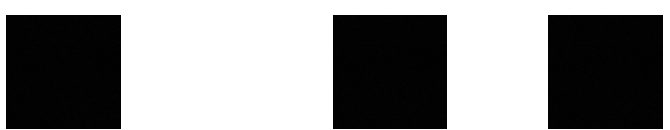

$\bigcirc$ Die von Welt Herr der Ringe / Der Hobbit $\bigcirc$ Die Welt von The Witcher $\bigcirc$ Die Welt von Game of Thrones / Das Lied von Eis und Feuer

* Falls Sie mehrere dieser Beispiele konsumiert haben, wählen Sie das Beispiel, zu dem Sie bereits die meisten Inhalte konsumiert haben. 
Hast du zuerst die Bücher gelesen oder die Filme gesehen?

Fragesupport: Wählen Sie eine Antwort

Buch / Roman Reihe

Film

$\bigcirc$ Andere...

In den folgenden Schritten, werden dir verschiedene Adaptionen deines Bespiels vorgestellt. Bitte teil uns mit ob du sowas schon einmal genutzt hast und warum oder warum nicht.

Hast du schon einmal einen Film der "Der Herr der Ringe" oder "Der Hobbit" Trilogie gesehen? Fragesupport: Wählen Sie eine Antwort

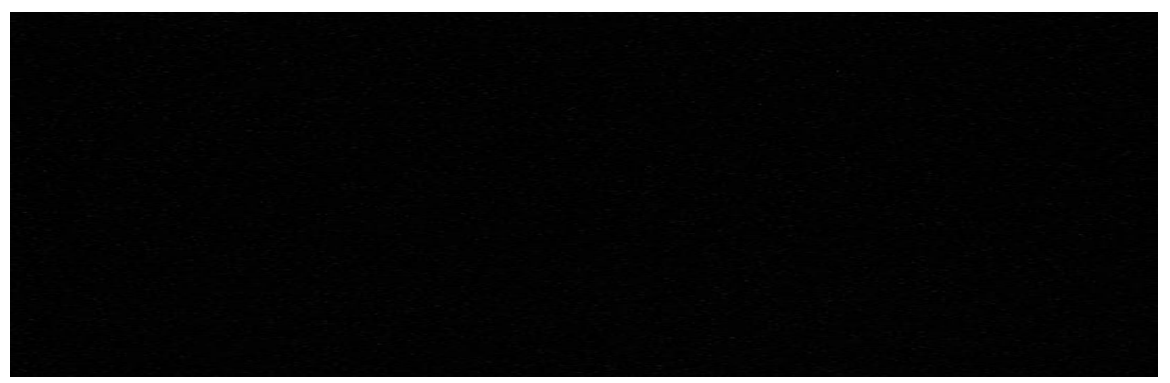

$\bigcirc$ Ja $\bigcirc$ Nein $\bigcirc \bigcirc \bigcirc \bigcirc$

Als du die Filme gesehen hast, wolltest du...

Fragesupport: Wählen Sie eine Antwort

mehr über die Story und über die Welt von Mittelerde und deren Geschöpfe erfahren.

die selbe Story noch einmal in einer anderen Medien-Form wieder erleben.

Andere...

Nein, weil...

Fragesupport: Wählen Sie eine Antwort

ich kein Interesse an den Filmen habe, die Stories in Mittelerde erzählen.

ich keine Filme schauen kann (z.B. durch fehlende Hardware oder körperliche Beeinträchtigungen).

$\bigcirc$ ich generell keine Filme oder Serien schaue.

ich bisher nicht dazu kam. Aber ich habe Interesse daran.

Andere... 
Hast du schon einmal ein Buch gelesen, dessen Story in Mittelerde stattfindet?

Fragesupport: Wählen Sie eine Antwort

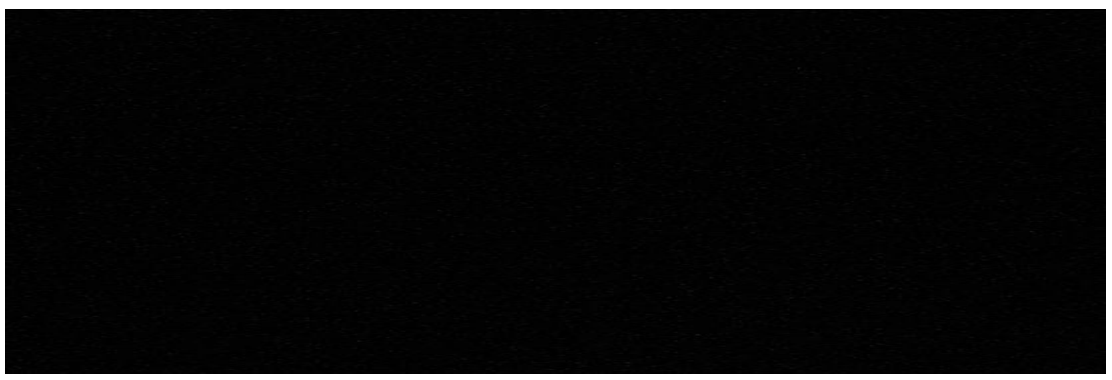

$\bigcirc$ Ja $\bigcirc$ Nein $\bigcirc \bigcirc \bigcirc \bigcirc \bigcirc$

* (z.B. Die "Der Herr der Ringe" Romanreihe, "Das Simarillion", oder auch Stan Nicholls' "Die Orks")

Als ich die Bücher gelesen habe, wollte ich ...

Fragesupport: Wählen Sie eine Antwort

mehr über die Story und über die Welt von Mittelerde und deren Geschöpfe erfahren.

die selbe Story noch einmal in einer anderen Medien-Form wieder erleben.

$\bigcirc$ Andere...

Nein, weil...

Fragesupport: Wählen Sie eine Antwort

ich kein Interesse an Büchern habe, dessen Stories in Mittelerde spielen.

$\bigcirc$ ich keine Bücher lesen kann (z.B. durch körperliche Beeinträchtigungen).

$\bigcirc$ ich generell keine Bücher lese.

ich bisher nicht dazu kam. Aber ich habe Interesse daran.

Andere... 
Hast du schon einmal ein Computerspiel gespielt, dessen Story in Mittelerde stattfindet?

Fragesupport: Wählen Sie eine Antwort

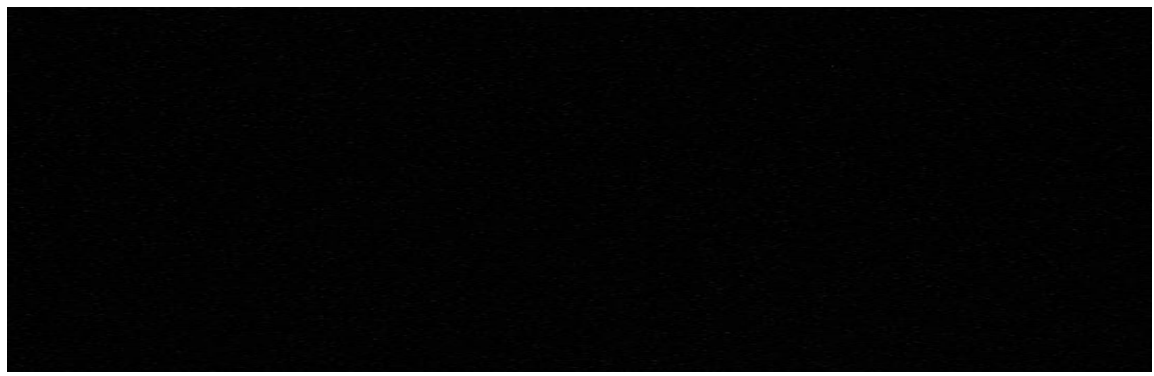

$\bigcirc$ Ja $\bigcirc$ Nein $\bigcirc \bigcirc \bigcirc \bigcirc \bigcirc$

${ }^{*}$ Info: Die Konsole ist dabei unwichtig.

(z.B. Spiele wie "Mittelerde - Mordors Schatteh̆" Der Herr der Ringe: Der Krieg im Nordënl' Der Herr der Ringe - Das dritte Zeitaltëroder " Wächter von Mittelerde" )

Als ich das Computerspiel gespielt habe, wollte ich...

Fragesupport: Wählen Sie eine Antwort

mehr über die Story und über die Welt von Mittelerde und deren Geschöpfe erfahren.

die selbe Story noch einmal in einer anderen Medien-Form wieder erleben.

Andere.

Nein, weil...

Fragesupport: Wählen Sie eine Antwort

ich kein Interesse an Computerspielen mit dem Mittelerde-Setting habe.

$\bigcirc$ ich keine Computerspiele spielen kann (z.B. Fehlende Hardware oder durch körperliche Beeinträchtigungen).

ich generell keine Computerspiele spiele.

ich bisher nicht dazu kam. Aber ich habe Interesse daran.

Andere... 
Hast du schon einmal einen Comic gelesen, dessen Story in Mittelerde stattfindet?

Fragesupport: Wählen Sie eine Antwort

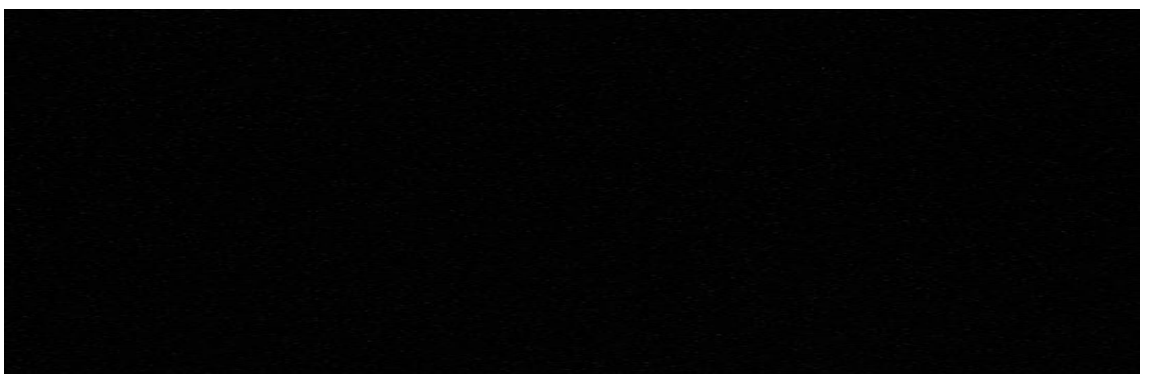

$\bigcirc$ Ja $\bigcirc$ Nein $\bigcirc \bigcirc \bigcirc \bigcirc \bigcirc$

* (Darunter zählen auch Comic-Adaptionen von "Der Herr der Ringe" und "Der kleine Hobbit")

Als ich den Comic gelesen habe, wollte ich ...

Fragesupport: Wählen Sie eine Antwort

mehr über die Story und über die Welt von Mittelerde und deren Geschöpfe erfahren.

die selbe Story noch einmal in einer anderen Medien-Form wieder erleben.

$\bigcirc$ Andere...

Nein, weil...

Fragesupport: Wählen Sie eine Antwort

$\bigcirc$ ich kein Interesse an Comics habe, dessen Stories in Mittelerde spielen.

$\bigcirc$ ich keine Comics lesen kann (z.B. durch körperliche Beeinträchtigungen).

ich generell keine Comics lese.

$\bigcirc$ ich bisher nicht dazu kam. Aber ich habe Interesse daran.

Andere... 
Hast du schon einmal eine Webseite oder ein Online-Wiki genutzt, dessen Inhalte sich auf die Welt von Mittelerde beziehen?

Fragesupport: Wählen Sie eine Antwort

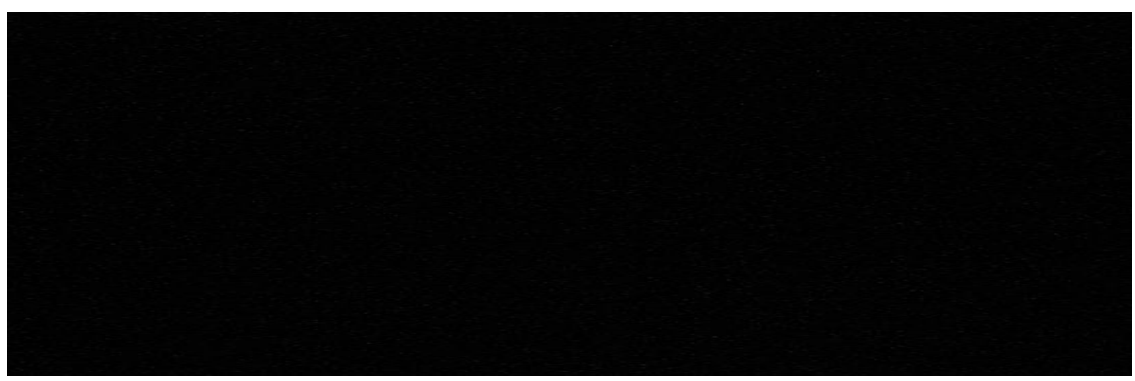

$\bigcirc$ Ja $\bigcirc$ Nein $\bigcirc \bigcirc \bigcirc \quad \bigcirc \quad \bigcirc$

Als ich die Webseite bzw. das Online-Wiki besucht habe, wollte ich ...

Fragesupport: Wählen Sie eine Antwort

mehr über die Story und über die Welt von Mittelerde und deren Geschöpfe erfahren.

mit anderen Fans in Kontakt treten.

Fanfictions lesen.

$\bigcirc$ eine Fanfiction veröffentlichen.

Andere...

Nein, weil...

Fragesupport: Wählen Sie eine Antwort

ich kein Interesse an Webseiten/Online-Wikis habe, die Inhalte aus Mittelerde aufgreifen.

$\bigcirc$ ich keine Webseiten/Online-Wikis besuchen kann (z.B. durch körperliche Beeinträchtigungen).

$\bigcirc$ ich generell keine Webseiten/Online-Wikis besuche.

ich bisher nicht dazu kam. Aber ich habe Interesse daran.

$\bigcirc$ Andere... 
Hast du schon einmal Merchandise-Produkte mit Bezug zu "Der Herr der Ringe" oder "Der Hobbit" gekauft?

Fragesupport: Wählen Sie eine Antwort

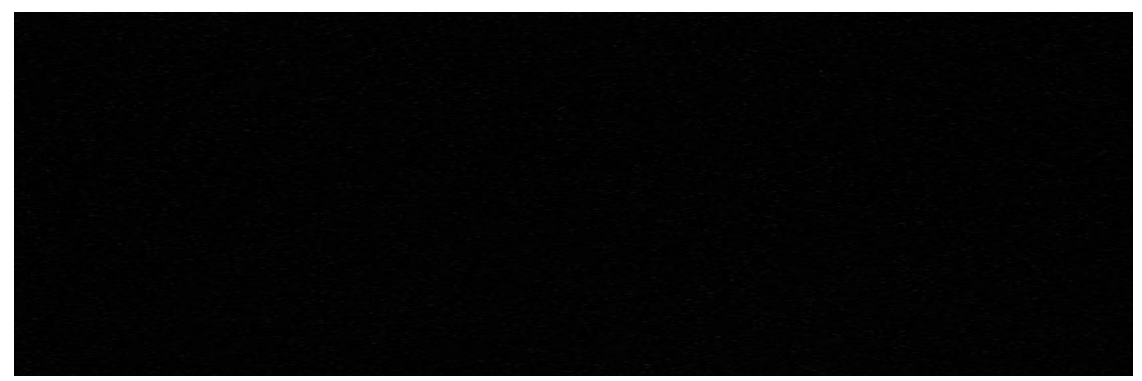

$\bigcirc$ лa $\bigcirc$ Nein $\bigcirc \quad \bigcirc \quad \bigcirc \quad \bigcirc$

* ( z.B. Brett- und Kartenspiele, Action-Figuren, Kleidung, Schmuck usw.)

Als ich diese Merchandise-Produkte gekauft habe, wollte ich...

Fragesupport: Wählen Sie eine Antwort

mehr über die Story und über die Welt von Mittelerde und deren Geschöpfe erfahren.

mich damit als Fan dieser Fantasywelt zu erkennen geben.

$\bigcirc$ Andere...

Nein, weil...

Fragesupport: Wählen Sie eine Antwort

$\bigcirc$ ich kein Interesse an Merchandise-Produkten habe, die Bezug zu "Der Herr der Ringe" / "Der Hobbit" haben.

$\bigcirc$ ich generell kein Interesse an Merchandise-Produkten habe.

ich bisher nicht dazu kam. Aber ich habe Interesse daran.

$\bigcirc$ Andere...

Fast Geschafft!

Es fehlen nur noch ein paar Informationen zu deiner Person. 
Du bist ...

Fragesupport: Wählen Sie eine Antwort

Männlich

Weiblich

Divers

Zu welcher Altersgruppe gehörst du?

Fragesupport: Wählen Sie eine Antwort
12 - 17 Jahre
18 - 24 Jahre
25 - 35 Jahre
36 - 49 Jahre
50 - 62 Jahre
$\bigcirc$ > 62 Jahre

\section{Was ist deine momentane (Haupt-)Berufstätigkeit?}

Fragesupport: Wählen Sie eine Antwort

$\bigcirc$ Vollzeit - Berufstätig

Teilzeit - Berufstätig

Studierend

Auszubildend

Schüler/Schülerin

$\bigcirc$ Derzeit nicht Berufstätig

Hast du zuerst die Bücher gelesen oder die Serie geschaut?

Fragesupport: Wählen Sie eine Antwort

Buch / Roman Reihe (Das Lied von Eis und Feuer)

$\bigcirc$ Serie (Game of Thrones)

In den folgenden Schritten, werden dir verschiedene Adaptionen deines Bespiels vorgestellt. Bitte teil uns mit ob du sowas schon einmal genutzt hast und warum oder warum nicht. 
Hast du schon einmal bewusst und aktiv die Serie "Game of Thrones" geschaut?

Fragesupport: Wählen Sie eine Antwort

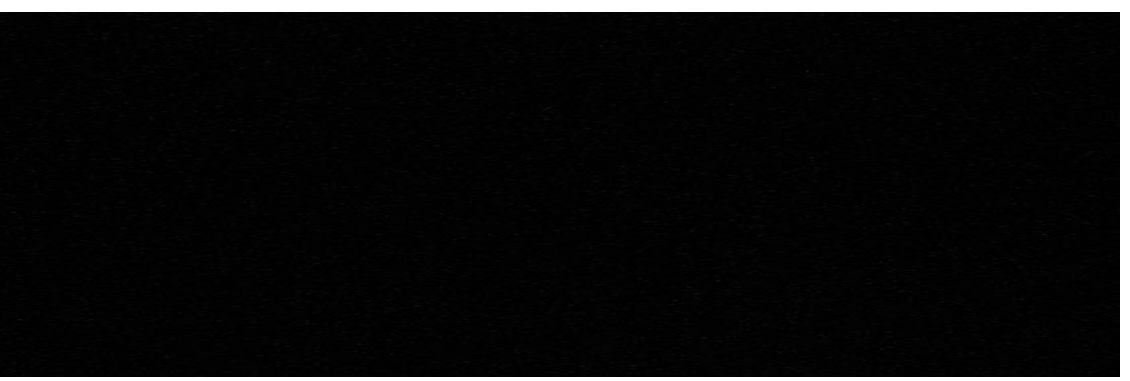

$\bigcirc$ Ja $\bigcirc$ Nein $\bigcirc \bigcirc \bigcirc \bigcirc \bigcirc$

Als du die Serie gesehen hast, wolltest du...

Fragesupport: Wählen Sie eine Antwort

mehr über die Story und über die Welt von Westeros und deren Charaktere erfahren.

$\bigcirc$ die selbe Story noch einmal in einer anderen Medien-Form wieder erleben.

$\bigcirc$ Andere...

Nein, weil...

Fragesupport: Wählen Sie eine Antwort

$\mathrm{ich}$ kein Interesse an der Serie habe.

$\bigcirc$ ich keine Filme schauen kann (z.B. durch fehlende Hardware oder körperliche Beeinträchtigungen).

$\bigcirc$ ich generell keine Filme oder Serien schaue.

ich bisher nicht dazu kam. Aber ich habe Interesse daran.

$\bigcirc$ Andere... 
Hast du schon einmal ein Buch gelesen, dessen Story in Westeros stattfindet?

Fragesupport: Wählen Sie eine Antwort

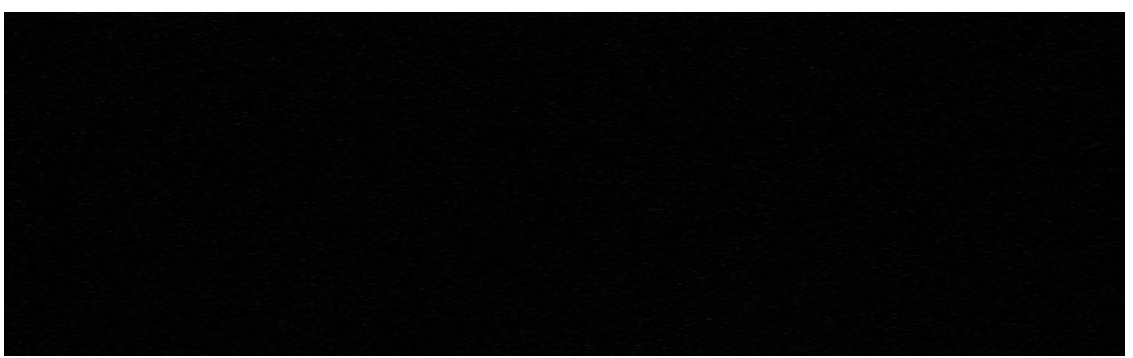

$\bigcirc$ Ja $\bigcirc$ Nein $\bigcirc \bigcirc \bigcirc \bigcirc \bigcirc$

" (z.B. Die "Das Lied von Eis und Feuer" Romanreihe, "Feuer und Blut", oder auch "Der Heckenritter von Westeros")

Als ich die Bücher gelesen habe, wollte ich ...

Fragesupport: Wählen Sie eine Antwort

mehr über die Story und über die Welt von Westeros und deren Charaktere erfahren.

$O$ die selbe Story noch einmal in einer anderen Medien-Form wieder erleben.

$\bigcirc$ Andere...

Nein, weil...

Fragesupport: Wählen Sie eine Antwort

$\bigcirc$ ich kein Interesse an Büchern habe, dessen Stories in Westeros spielen.

$\bigcirc$ ich keine Bücher lesen kann (z.B. durch körperliche Beeinträchtigungen).

ich generell keine Bücher lese.

$\bigcirc$ ich bisher nicht dazu kam. Aber ich habe Interesse daran.

Andere... 
Hast du schon einmal ein Computerspiel gespielt, dessen Story in Westeros stattfindet?

Fragesupport: Wählen Sie eine Antwort

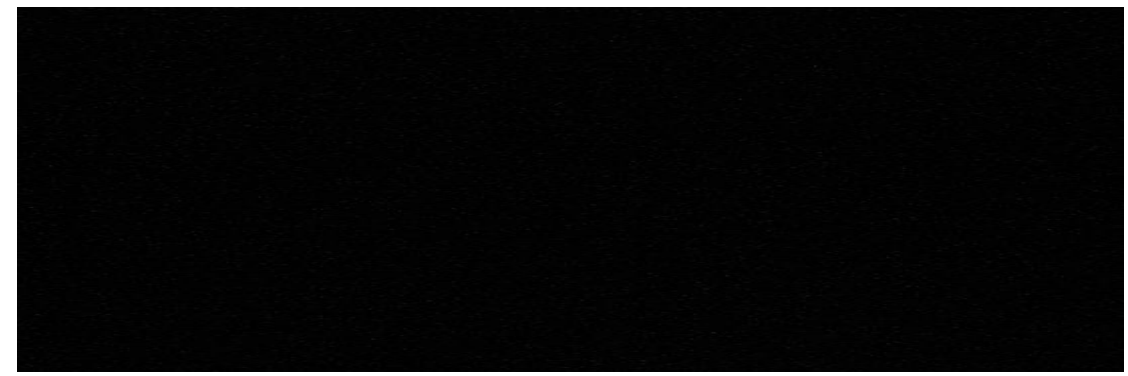

$\bigcirc$ Ja $\bigcirc$ Nein $\bigcirc \bigcirc \bigcirc \bigcirc \bigcirc$

* Info: Die Konsole ist dabei unwichtig.

(z.B. Spiele wie "Iron From Ice - A Game of Thrones Tellgame", "Game of Thrones: Genesis", oder "Game of Thrones: Conquest")

Als ich das Computerspiel gespielt habe, wollte ich...

Fragesupport: Wählen Sie eine Antwort

mehr über die Story und über die Welt von Westeros und deren Charaktere erfahren.

die selbe Story noch einmal in einer anderen Medien-Form wieder erleben.

Andere...

Nein, weil...

Fragesupport: Wählen Sie eine Antwort

$\bigcirc$ ich kein Interesse an Computerspielen mit dem Westeros-Setting habe.

$\bigcirc$ ich keine Computerspiele spielen kann (z.B. Fehlende Hardware oder durch körperliche Beeinträchtigungen).

ich generell keine Computerspiele spiele.

$\bigcirc$ ich bisher nicht dazu kam. Aber ich habe Interesse daran.

Andere... 
Hast du schon einmal einen Comic gelesen, dessen Story in Westeros stattfindet?

Fragesupport: Wählen Sie eine Antwort

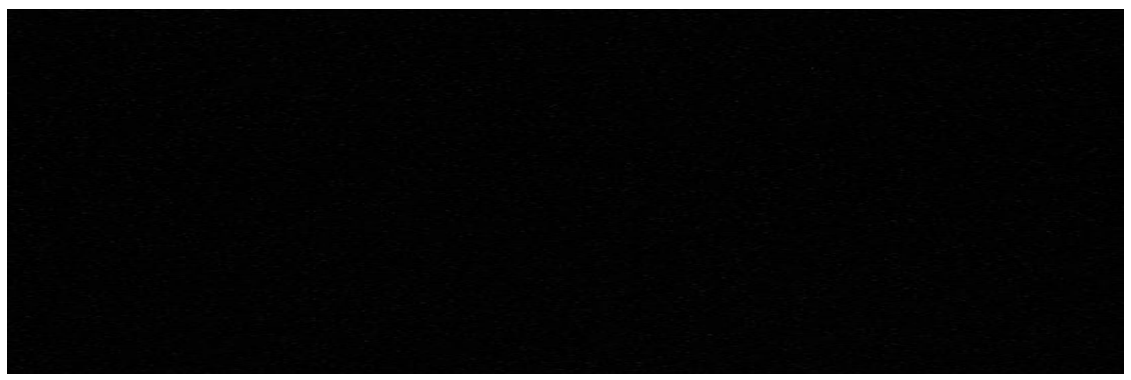

$\bigcirc$ Ja $\bigcirc$ Nein $\bigcirc \bigcirc \bigcirc \bigcirc \bigcirc$

Als ich den Comic gelesen habe, wollte ich ...

Fragesupport: Wählen Sie eine Antwort

mehr über die Story und über die Welt von Westeros und deren Charaktere erfahren.

die selbe Story noch einmal in einer anderen Medien-Form wieder erleben.

$\bigcirc$ Andere...

Nein, weil...

Fragesupport: Wählen Sie eine Antwort

$\bigcirc$ ich kein Interesse an Comics habe, dessen Stories in Westeros spielen.

$\bigcirc$ ich keine Comics lesen kann (z.B. durch körperliche Beeinträchtigungen).

$\bigcirc$ ich generell keine Comics lese.

ich bisher nicht dazu kam. Aber ich habe Interesse daran.

$\bigcirc$ Andere.. 
Hast du schon einmal eine Webseite oder ein Online-Wiki genutzt, dessen Inhalte sich auf die Welt von Westeros bzw. Essos beziehen?

Fragesupport: Wählen Sie eine Antwort

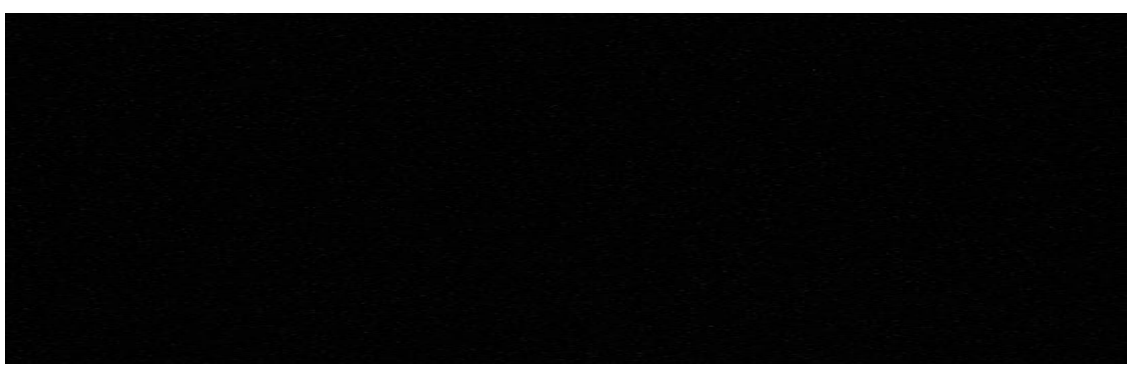

$\mathrm{O}_{\mathrm{Ja}} \bigcirc \mathrm{Nein} \bigcirc \mathrm{O} \quad \mathrm{O} \quad \mathrm{O}$

Als ich die Webseite bzw. das Online-Wiki besucht habe, wollte ich ...

Fragesupport: Wählen Sie eine Antwort

mehr über die Story und über die Welt von Westeros und deren Charaktere erfahren.

mit anderen Fans in Kontakt treten.

Fanfictions lesen.

$\bigcirc$ eine Fanfiction veröffentlichen.

Andere...

Nein, weil...

Fragesupport: Wählen Sie eine Antwort

ich kein Interesse an Webseiten/Online-Wikis habe, die Inhalte aus Westeros und Essos aufgreifen.

$\bigcirc$ ich keine Webseiten/Online-Wikis besuchen kann (z.B. durch körperliche Beeinträchtigungen).

$\bigcirc$ ich generell keine Webseiten/Online-Wikis besuche.

ich bisher nicht dazu kam. Aber ich habe Interesse daran.

$\bigcirc$ Andere... 
Hast du schon einmal Merchandise-Produkte mit Bezug zu "Game of Thrones" gekauft?

Fragesupport: Wählen Sie eine Antwort

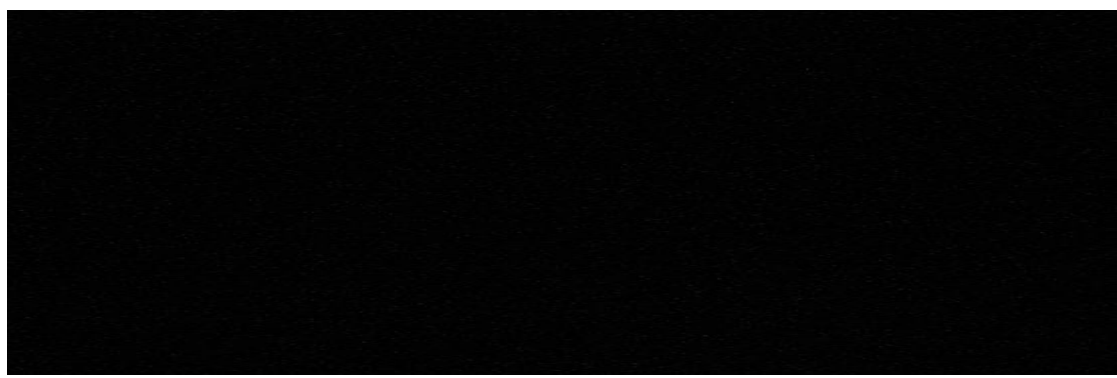

$\bigcirc$ Ja $\bigcirc$ Nein $\bigcirc \bigcirc \bigcirc \bigcirc \bigcirc$

"bzw. auch Bezug zu "Das Lied von Eis und Feuer".

(z.B. Brett- und Kartenspiele, Action-Figuren, Kleidung, Schmuck usw.)

Als ich diese Merchandise-Produkte gekauft habe, wollte ich...

Fragesupport: Wählen Sie eine Antwort

mehr über die Story und über die Welt von Westeros und deren Charaktere erfahren.

mich damit als Fan dieser Fantasywelt zu erkennen geben.

Andere...

Nein, weil...

Fragesupport: Wählen Sie eine Antwort

ich kein Interesse an Merchandise-Produkten habe, die Bezug zu "Game of Thrones" haben.

$\bigcirc$ ich generell kein Interesse an Merchandise-Produkten habe.

ich bisher nicht dazu kam. Aber ich habe Interesse daran.

$\bigcirc$ Andere...

Fast Geschafft

Es fehlen nur noch ein paar Informationen zu deiner Person. 
Du bist ...

Fragesupport: Wählen Sie eine Antwort

Männlich

Weiblich

Divers

Zu welcher Altersgruppe gehörst du?

Fragesupport: Wählen Sie eine Antwort
12 - 17 Jahre
18 - 24 Jahre
25 - 35 Jahre
36 - 49 Jahre
50 - 62 Jahre
$>$ > 62 Jahre

Was ist deine momentane (Haupt-)Beruftätigkeit?

Fragesupport: Wählen Sie eine Antwort

$\bigcirc$ Vollzeit - Berufstätig

Teilzeit - Berufstätig

Studierend

Auszubildend

Schüler/Schülerin

Derzeit nicht Berufstätig

Hast du zuerst die Bücher gelesen oder die Spiele gespielt?

Fragesupport: Wählen Sie eine Antwort

Buch / Roman Reihe

Spiel / Spiele Reihe

In den folgenden Schritten, werden dir verschiedene Adaptionen deines Bespiels vorgestellt. Bitte teil uns mit ob du sowas schon einmal genutzt hast und warum oder warum nicht. 
Hast du schon einmal einen Spiel der "The Witcher" - Spielereihe gespielt?

Fragesupport: Wählen Sie eine Antwort

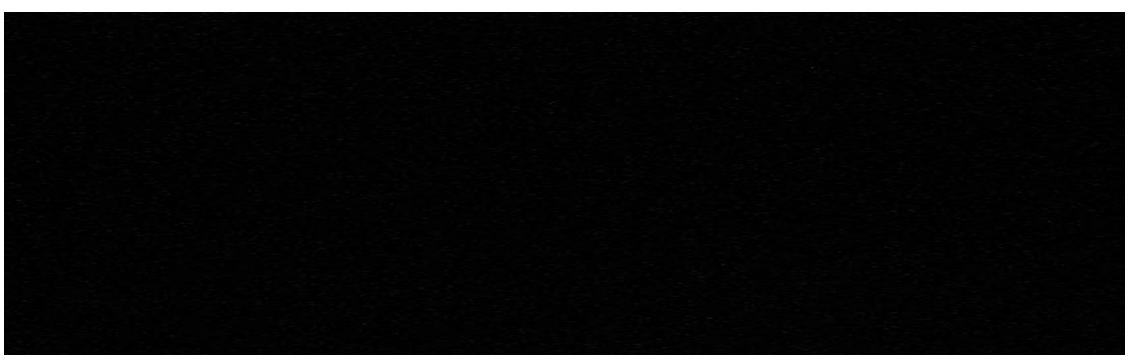

$\bigcirc$ Ja $\bigcirc$ Nein $\bigcirc \bigcirc \bigcirc \bigcirc \bigcirc$

" Info: Die Konsole ist dabei unwichtig.

(z.B. Spiele wie "The Witcher I', "The Witcher Il: Assassins of Kings ", "The Witcher III: Wild Hunt", oder "Thronebreaker: The Witcher Tales ")

Als ich die Computerspiele gespielt habe, wollte ich...

Fragesupport: Wählen Sie eine Antwort

mehr über die Story und über die Welt von "The Witcher" und deren Geschöpfe erfahren.

die selbe Story noch einmal in einer anderen Medien-Form wieder erleben.

Andere...

Nein, weil...

Fragesupport: Wählen Sie eine Antwort

ich kein Interesse an Computerspielen von "The Witcher" habe.

ich keine Computerspiele spielen kann (z.B. Fehlende Hardware oder durch körperliche Beeinträchtigungen).

ich generell keine Computerspiele spiele.

ich bisher nicht dazu kam. Aber ich habe Interesse daran.

Andere... 
Hast du schon einmal ein Buch gelesen, dessen Story in der Welt von "The Witcher" stattfindet?

Fragesupport: Wählen Sie eine Antwort

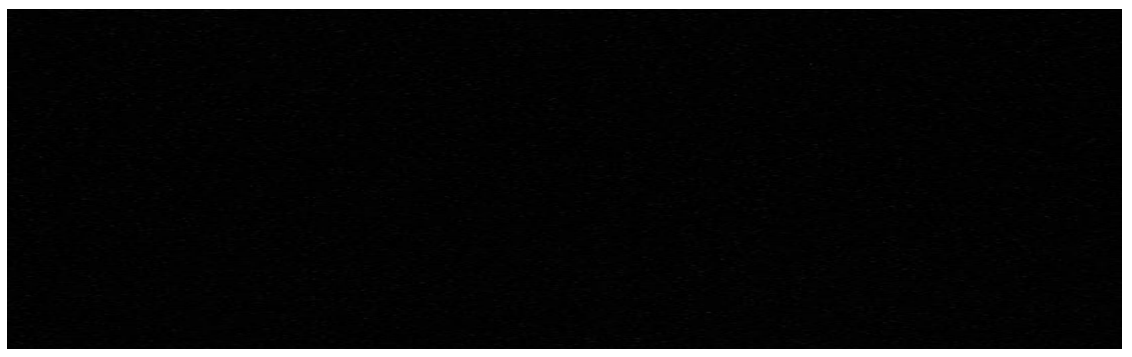

$\bigcirc$ Ja $\bigcirc$ Nein $\bigcirc \bigcirc \bigcirc \bigcirc \bigcirc$

* (z.B. Die Bücher "Der letzte Wunsch", " Zeit des Sturms ", "Das Schwert der Vorsehung" oder "Das Erbe der Elfen")

Als ich die Bücher gelesen habe, wollte ich ...

Fragesupport: Wählen Sie eine Antwort

mehr über die Story und über die Welt von "The Witcher" und deren Geschöpfe erfahren.

die selbe Story noch einmal in einer anderen Medien-Form wieder erleben.

$\bigcirc$ Andere...

Nein, weil...

Fragesupport: Wählen Sie eine Antwort

$\bigcirc$ ich kein Interesse an Büchern habe, dessen Stories von "The Witcher" handeln.

$\bigcirc$ ich keine Bücher lesen kann (z.B. durch körperliche Beeinträchtigungen).

$\bigcirc$ ich generell keine Bücher lese.

ich bisher nicht dazu kam. Aber ich habe Interesse daran.

$\bigcirc$ Andere... 
Hast du schon einmal einen Film oder eine Serie gesehen, dessen Plot sich um "Geralt von Riva" dreht?

Fragesupport: Wählen Sie eine Antwort

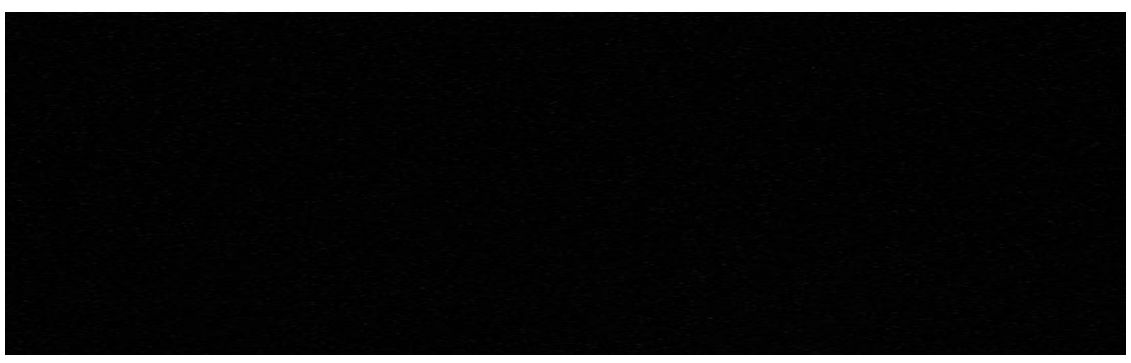

$\bigcirc$ Ja $\bigcirc$ Nein $\bigcirc \bigcirc \bigcirc \bigcirc \bigcirc$

Als du die Filme/Serie geschaut hast, wolltest du...

Fragesupport: Wählen Sie eine Antwort

mehr über die Story und über die Welt von "The Witcher" und deren Geschöpfe erfahren.

die selbe Story noch einmal in einer anderen Medien-Form wieder erleben.

$\bigcirc$ Andere...

Nein, weil...

Fragesupport: Wählen Sie eine Antwort

ich kein Interesse an Filmen oder Serien habe, dessen Stories von "The Witcher" handeln.

$\bigcirc$ ich keine Filme oder Serien schauen kann (z.B. durch fehlende Hardware oder körperliche Beeinträchtigungen).

$\bigcirc$ ich generell keine Filme oder Serien schaue.

$\bigcirc$ ich bisher nicht dazu kam. Aber ich habe Interesse daran. (z.B. an der kommenden Netflix Produktion "The Witcher")

Andere... 
Hast du schon einmal einen Comic gelesen, dessen Story von "Geralt von Riva" handelt?

Fragesupport: Wählen Sie eine Antwort

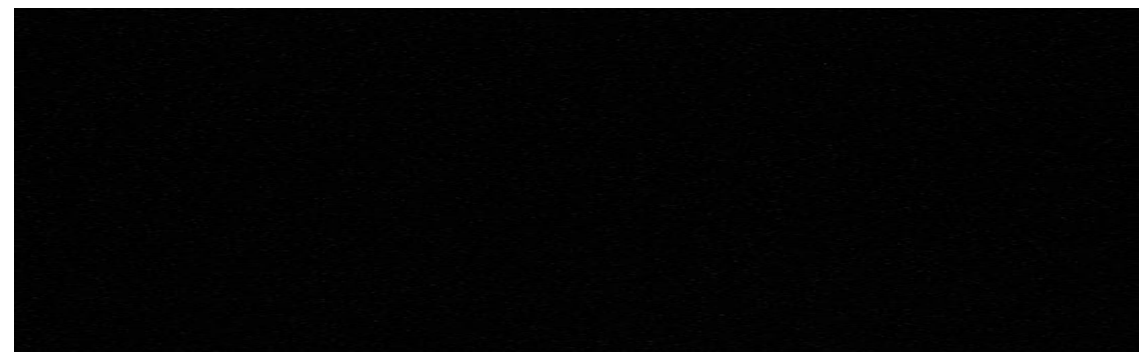

$\bigcirc$ Ja $\bigcirc$ Nein $\bigcirc \bigcirc \bigcirc \bigcirc \bigcirc$

Als ich den Comic gelesen habe, wollte ich ...

Fragesupport: Wählen Sie eine Antwort

mehr über die Story und über die Welt von The Witcher und deren Geschöpfe erfahren.

die selbe Story noch einmal in einer anderen Medien-Form wieder erleben.

$\bigcirc$ Andere...

Nein, weil...

Fragesupport: Wählen Sie eine Antwort

ich kein Interesse an Filmen oder Serien habe, dessen Stories von "The Witcher" handeln.

ich keine Comics lesen kann (z.B. durch körperliche Beeinträchtigungen).

$\bigcirc$ ich generell keine Comics lese.

ich bisher nicht dazu kam. Aber ich habe Interesse daran.

$\bigcirc$ Andere... 
Hast du schon einmal eine Webseite oder ein Online-Wiki genutzt, dessen Inhalte sich auf die Welt von "The Witcher" bezieht?

Fragesupport: Wählen Sie eine Antwort

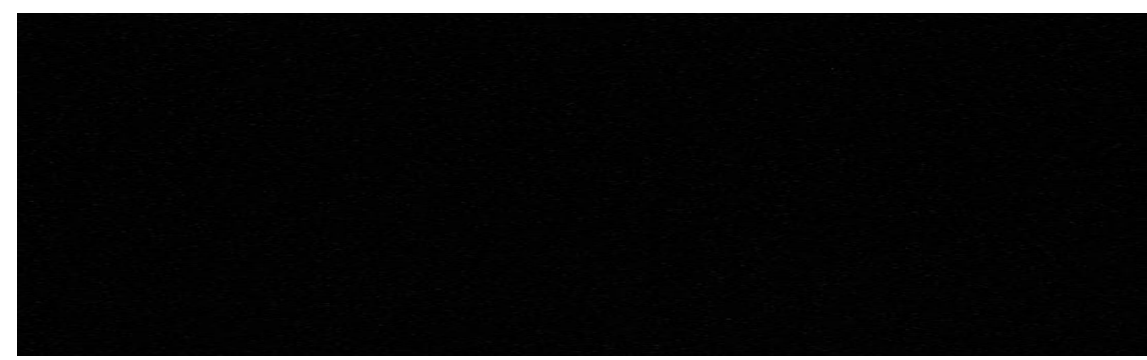

$\bigcirc$ Ja $\bigcirc$ Nein $\bigcirc \bigcirc \bigcirc \bigcirc \bigcirc$

Als ich die Webseite bzw. das Online-Wiki besucht habe, wollte ich ...

Fragesupport: Wählen Sie eine Antwort

mehr über die Story und über die Welt von "The Witcher" und deren Geschöpfe erfahren.

mit anderen Fans in Kontakt treten.

Fanfictions lesen.

eine Fanfiction veröffentlichen.

Andere...

Nein, weil...

Fragesupport: Wählen Sie eine Antwort

ich kein Interesse an Webseiten/Online-Wikis habe, die Inhalte aus "The Witcher" aufgreifen.

$\bigcirc$ ich keine Webseiten/Online-Wikis besuchen kann (z.B. durch körperliche Beeinträchtigungen).

$O$ ich generell keine Webseiten/Online-Wikis besuche.

$\bigcirc$ ich bisher nicht dazu kam. Aber ich habe Interesse daran.

$\bigcirc$ Andere... 
Hast du schon einmal Merchandise-Produkte mit Bezug zu "The Witcher" gekauft?

Fragesupport: Wählen Sie eine Antwort

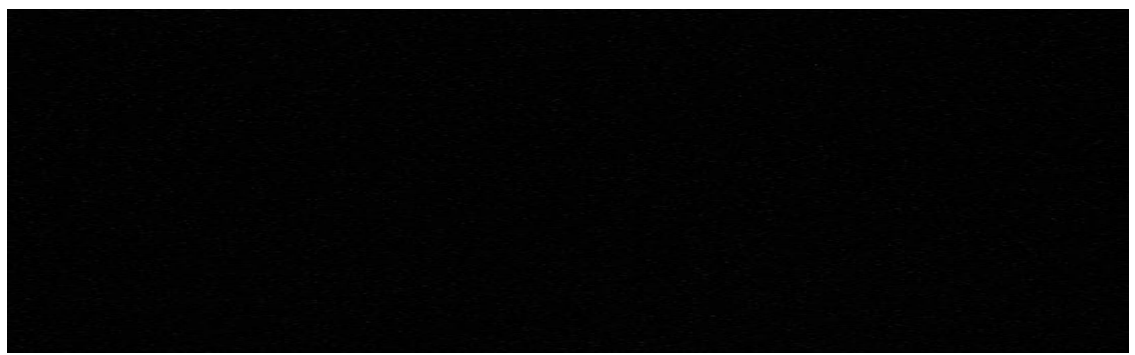

$\bigcirc$ Ja $\bigcirc$ Nein $\bigcirc \bigcirc \bigcirc \bigcirc \bigcirc$

* ( z.B. Brett- und Kartenspiele, Action-Figuren, Kleidung, Schmuck usw.)

Als ich diese Merchandise-Produkte gekauft habe, wollte ich...

Fragesupport: Wählen Sie eine Antwort

mehr über die Story und über die Welt von The Witcher und deren Geschöpfe erfahren.

mich damit als Fan dieser Fantasywelt zu erkennen geben.

$\bigcirc$ Andere...

Nein, weil...

Fragesupport: Wählen Sie eine Antwort

$\bigcirc$ ich kein Interesse an Merchandise-Produkten habe, die Bezug zu "The Witcher" haben.

$\bigcirc$ ich generell kein Interesse an Merchandise-Produkten habe.

ich bisher nicht dazu kam. Aber ich habe Interesse daran.

Andere...

Fast Geschafft!

Es fehlen nur noch ein paar Informationen zu deiner Person.

Du bist ...

Fragesupport: Wählen Sie eine Antwort

Männlich

Weiblich

Divers 
Zu welcher Altersgruppe gehörst du?

Fragesupport: Wählen Sie eine Antwort
12 - 17 Jahre
18 - 24 Jahre
O 25 - 35 Jahre
36 - 49 Jahre
50 - 62 Jahre
> 62 Jahre

\section{Was ist deine momentane (Haupt-)Berufstätigkeit?}

Fragesupport: Wählen Sie eine Antwort

Vollzeit - Berufstätig

Teilzeit - Berufstätig

Studierend

Auszubildend

Schüler/Schülerin

$\bigcirc$ Derzeit nicht Berufstätig

Willst du an unserem Gewinnspiel teilnehmen?

Fragesupport: Wählen Sie eine Antwort

$\bigcirc$ ja $\bigcirc$ Nein $\bigcirc \bigcirc \bigcirc \bigcirc \bigcirc$

Der Gewinner wird am 01.11.2019 ermittelt und via E-Mail kontaktiert.

Der Gutschein wird in Form eines Codes via E-Mail am 01.11.2019 dem Gewinner zugesandt.

Teilnahmezeitraum ist vom 15.09. bis 15.10 .2019

Teinnehmer des Gewinnspiels müssen mindestens 18 Jahre alt sein.

Der Rechtsweg ist ausgeschlossen

Geschafft!

Abschießend kannst du an unserem Gewinnspiel teilnehmen.

Zu gewinnen gibt es einen $50 €$ Gutschein für Amazon!

Wir brauchen nur noch deine E-Mail Adresse!

Fragesupport: Bitte gib deine E-Mail Adresse an. 
Der Gewinner wird am 01.11.2019 kontaktiert! 
